Édités par

\title{
Jean-Charles FALARDEAU
}

(1953)

\section{ESSAIS SUR LE QUÉBEC CONTEMPORAIN}

\section{ESSAYS ON CONTEMPORARY QUEBEC}

\author{
Symposium du centenaire de l'Université Laval.
}
Un document produit en version numérique par Mme Marcelle Bergeron, bénévole Professeure à la retraite de l'École Dominique-Racine de Chicoutimi, Québec et collaboratrice bénévole Courriel : $\underline{\text { mabergeron} @ \text { videotron.ca }}$

Dans le cadre de la collection : "Les classiques des sciences sociales" dirigée et fondée par Jean-Marie Tremblay, professeur de sociologie au Cégep de Chicoutimi Site web: http://classiques.uqac.ca/

Une collection développée en collaboration avec la Bibliothèque Paul-Émile-Boulet de l'Université du Québec à Chicoutimi Site web: http://classiques.uqac.ca 


\section{Politique d'utilisation de la bibliothèque des Classiques}

Toute reproduction et rediffusion de nos fichiers est interdite, même avec la mention de leur provenance, sans l'autorisation formelle, écrite, du fondateur des Classiques des sciences sociales, Jean-Marie Tremblay, sociologue.

Les fichiers des Classiques des sciences sociales ne peuvent sans autorisation formelle:

- être hébergés (en fichier ou page web, en totalité ou en partie) sur un serveur autre que celui des Classiques.

- servir de base de travail à un autre fichier modifié ensuite par tout autre moyen (couleur, police, mise en page, extraits, support, etc...),

Les fichiers (.html, .doc, .pdf, .rtf, .jpg, .gif) disponibles sur le site Les Classiques des sciences sociales sont la propriété des Classiques des sciences sociales, un organisme à but non lucratif composé exclusivement de bénévoles.

Ils sont disponibles pour une utilisation intellectuelle et personnelle et, en aucun cas, commerciale. Toute utilisation à des fins commerciales des fichiers sur ce site est strictement interdite et toute rediffusion est également strictement interdite.

L'accès à notre travail est libre et gratuit à tous les utilisateurs. C'est notre mission.

Jean-Marie Tremblay, sociologue

Fondateur et Président-directeur général,

LES CLASSIQUES DES SCIENCES SOCIALES. 
Un document produit en version numérique par Mme Marcelle Bergeron, bénévole, professeure à la retraite de l'École Dominique-Racine de Chicoutimi, Québec.

Courriels :marcelle bergeron@uqac.ca; mabergeron@,videotron.ca

\section{Édités par JEAN-C. FALARDEAU}

\section{Essais sur le Québec contemporain. Essays on contemporary Quebec.}

Québec : Les Presses de l'Université Laval, 1953, 260 pp. Textes recueillis par Jean-C. Falardeau lors du symposium du centenaire de l'Université Laval tenu à l’Université Laval les 6 et 7 juin 1952.

[Autorisation formelle accordée le 30 novembre 2010, par le directeur général des Presses de l'Université Laval, M. Denis DION, de diffuser ce livre dans Les Classiques des sciences sociales.]

9. Courriel : $\quad$ denis.dion@pul.ulaval.ca
PUL :

Polices de caractères utilisés :

Pour le texte : Times New Roman, 12 points.

Pour les citations : Times New Roman 10 points.

Pour les notes de bas de page : Times New Roman, 10 points.

Édition électronique réalisée avec le traitement de textes Microsoft Word 2008 pour Macintosh.

Mise en page sur papier format : LETTRE US, $8.5^{\prime \prime}$ x 11 '”.

Édition complétée le 20 octobre, 2011 à Chicoutimi, Ville de Saguenay, Québec. 


\section{REMERCIEMENTS}

\section{Presses de PUniversité Laval}

Nous sommes infiniment reconnaissants à la direction des Presses de l'Université Laval, notamment à M. Denis DION, directeur général, pour la confiance qu'on nous a accordée, en nous autorisant, le 30 novembre 2010, la diffusion de ce livre dans Les Classiques des sciences sociales.

Qf.

Courriel : denis.dion@pul.ulaval.ca

PUL : $\quad$ http://www.pulaval.com/

Jean-Marie Tremblay,

Sociologue,

Fondateur, Les Classiques des sciences sociales.

20 octobre 2011. 
Édités par Jean-C. Falardeau

(1953)

Essais sur le Québec contemporain.

Essays on contemporary Quebec.

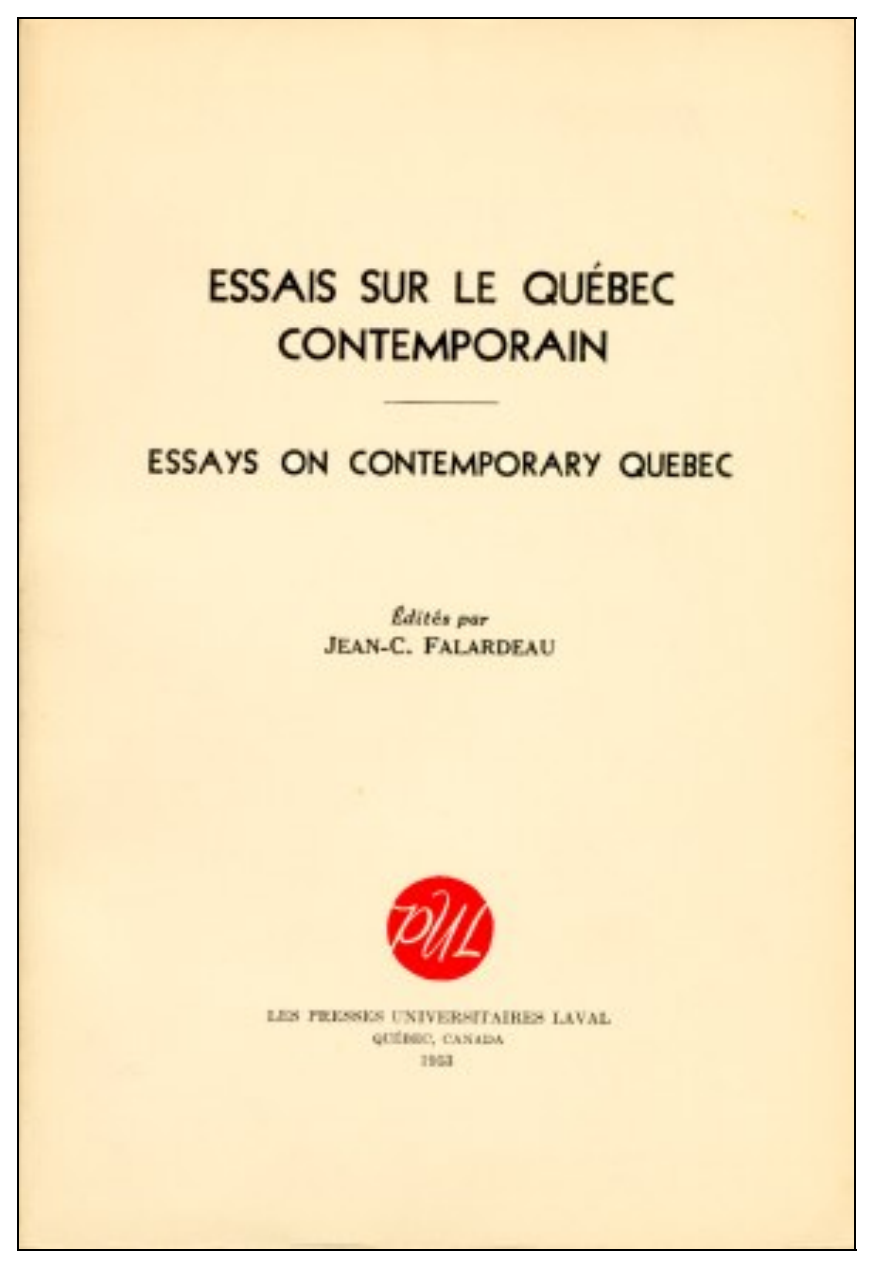

Québec : Les Presses de l'Université Laval, 1953, 260 pp. Textes recueillis par Jean-C. Falardeau lors du symposium du centenaire de l'Université Laval tenu à l'Université Laval les 6 et 7 juin 1952. 
[p. 259 et 260]

\section{TABLE DES MATIÈRES}

Programme du symposium

$\underline{\text { Liste des collaborateurs }}$

$\underline{\text { Remerciements }}$

AVANT-PROPOS. Jean-C. Falardeau

Chapitre I. $\quad$ HISTORY OF INDUSTRIAL DEVELOPMENT

Albert Faucher and Maurice Lamontagne

Comments.

O. J. Firestone

Chapitre II. RECENT INDUSTRIAL GROWTH

Chapitre III. THE STATE OF AGRICULTURE

Charles Lemelin

Chapitre IV. POPULATION PROBLEMS

Nathan Keyfitz

Comments.

Oswald Hall

Chapitre V. THE CHANGING SOCIAL STRUCTURES

Jean-C. Falardeau

Comments.

Aileen D. Ross

Chapitre VI. L'ÉVOLUTION JURIDIQUE

Jacques Perrault

Commentaires.

Eugene Forsey 
Chapitre VII. POLITICAL TRENDS

H. Mason Wade

Commentaires. $\quad$ Lorenzo Paré

Chapitre VIII. LE SYSTÈME SCOLAIRE

Léon Lortie

Commentaires. $\quad$ Arthur Tremblay

Chapitre IX. ORIENTATIONS DE LA PENSÉE SOCIALE

Maurice Tremblay

Commentaires. $\quad$ R.P. Jacques Cousineau, s.j.

Chapitre X. REGARDS SUR LE QUÉBEC

Everett-C. Hughes

Chapitre XI. CONDITIONS DE NOTRE AVENIR

Esdras Minville

Chapitre XII. PERSPECTIVES

Jean-C. Falardeau 
[p. 7]

Au Très Révérend Père Georges-H. Lévesque, O.P., M.S.R.C., Doyen

de la Faculté des Sciences sociales de l'Université Laval

À l'occasion du quinzième anniversaire de la Faculté dont il fut le fondateur et dont il demeure l'âme dirigeante

En témoignage de profonde estime pour la vision et le courage avec lesquels il n'a cessé d'inspirer l'orientation des sciences sociales au Canada français 
[p. 7-8]

\title{
PROGRAMME DU SYMPOSIUM
}

\author{
TENU À L'UNIVERSITÉ LAVAL
}

SUR

Les répercussions sociales de l'industrialisation dans la province de Québec les 6 et 7 juin 1952

\section{VENDREDI, 6 JUIN}

$\underline{\text { Retour à la table des matières }}$

Séance du matin

1. PRÊSENTATION DU SYMPOSIUM

2. PROLÉGOMÈNES HISTORIQUES :

a) Évolution industrielle
Président : F. A. Knox

Université Queen's.
Albert FAUCHER et Maurice LAMONTAGNE Université Laval.

Analyse : O. J. FIRESTONE, Ministère du Commerce, Ottawa.

b) Évolution agricole

Charles LEMELIN

Université Laval.

Analyse : D. L. MACFARLANE, Macdonald College, Université McGill.

Séance de l'après-midi

3. Changements démographiques
Président : B. S. Keirstead Université McGill.

Nathan Keyfitz

Bureau de la Statistique, Ottawa.

Analyse : Oswald HALL, Université McGill.

4. Évolution de l'organisation sociale, de la mentalité et des comportements collectifs

Jean-C. FALARDEAU

Université Laval.

Analyse : Aileen D. Ross, Université McGill. 


\section{SAMEDI, 7 JUIN}

Séance du matin

5. L'évolution juridique
Président : Jean-C.

\section{Bonenfant}

Université Laval.

Jacques PERRAULT

Université de Montréal.

Analyse : Eugène FORSEY, Conseil Canadien du Travail, Ottawa.

6. Évolution politique du Québec

\author{
H. Mason WADE \\ Université Catholique \\ d'Amérique.
}

Analyse : Lorenzo PARÉ, journaliste, Québec.

Séance de l'après-midi

7. Évolution du système d'enseignement
Président : T. R. P. Georges-

H. Lévesque, o.p.

Université Laval.

Léon LORTIE, Université de Montréal.

Analyse : Arthur TREMBLAY, Université Laval.

8. Orientations nouvelles de la pensée sociale

Analyse : R. P. Jacques COUSINEAU, s.j., Québec.

\section{Soirée}

9. Tour d'horizon
Maurice TREMBLAY

Université Laval.
Président : Esdras Minville

Université de Montréal.

Everett-C. HUGHES

Université de Chicago. 
[p. 9]

\section{LISTE DES COLLABORATEURS}

$\underline{\text { Retour à la table des matières }}$

M. ALBERT FAUCHER, professeur au Département d'Économique de la Faculté des Sciences sociales de l'Université Laval

M. MAURICE LAMONTAGNE, directeur du Département d'Économique de la Faculté des Sciences sociales de l'Université Laval

M. O. J. FIRESTONE, aviseur économique du Ministère du Commerce à Ottawa

M. CHARLES LEMELIN, professeur au Département d'Économique de la Faculté des Sciences sociales de l'Université Laval

M. NATHAN KEYFITZ, directeur des Recherches statistiques au Bureau de la statistique à Ottawa

M. OSWALD HALL, directeur du Département de Sociologie de l'Université McGill de Montréal

M. JEAN-C. FALARDEAU, directeur du Département de Sociologie de la Faculté des Sciences sociales de l'Université Laval

MADEMOISELLE AILBEN D. ROSS, professeur au Département de Sociologie de l'Université McGill de Montréal

$\mathrm{M}^{\mathrm{e}}$ JACQUES PERRAULT, avocat au Barreau de Montréal, professeur à la Faculté de Droit de l'Université de Montréal

M. EUGÈNE FORSEY, directeur des Recherches du Congrès Canadien du Travail à Ottawa

[p. 10]

M. H. MASON WADE, historien, auteur de The French-Canadian Outlook et de The French-Canadian Mind, ouvrage à paraître en 1954

M. LORENZO PARÉ, journaliste, adjoint du rédacteur-en-chef au journal Le Soleil, à Québec

M. LÉON LORTIE, directeur de l'Extension de l'Enseignement de l'Université de Montréal 
M. ARTHUR TREMBLAY, directeur-adjoint de l'École de Pédagogie et d'Orientation de l'Université Laval

M. MAURICE TREMBLAY, professeur au Département de Sociologie de la Faculté des Sciences sociales de l'Université Laval

Le R. P. JACQUES COUSINEAU, s.j., membre de la Commission sacerdotale d'Études sociales, longtemps conseiller moral dans plusieurs fédérations de la C.T.C.C.

M. EVERETT-C. HUGHES, directeur du Département de Sociologie de l'Université de Chicago

M. ESDRAS MINVILLE, directeur de l'École des Hautes Études commerciales de Montréal et doyen de la Faculté des Sciences sociales de l'Université de Montréal 
[p. 11]

\section{REMERCIEMENTS}

\section{$\underline{\text { Retour à la table des matières }}$}

Ce livre est par définition et de plus d'une façon le résultat de la collaboration invisible ou explicite d'un grand nombre de bonnes volontés. En tout premier lieu, il est l'œuvre des auteurs qui avaient accepté de présenter des travaux au symposium et qui ont ensuite généreusement consenti à réviser leurs textes pour la publication. À leurs noms sont associés les noms de ceux qui nous ont fait l'honneur de présider nos cinq séances d'étude et grâce au doigté desquels nos discussions furent si fécondes: MM. F. A. Knox, B. S. Keirstead, Jean-C. Bonenfant, le T. R. P. Georges-H. Lévesque, o.p., et M. Esdras Minville.

Quelques amis de langue anglaise, le R. P. P.-S. Mifflen, MM. R. Eigner, Douglas Barlow et William Mackey, ont eu la patience de lire et de corriger les manuscrits anglais des auteurs de langue française. Il ne faut pas leur imputer ce qui subsiste de faiblesse dans ces textes mais seulement leur savoir gré d'avoir aidé à actualiser notre intention générale de correction. Je tiens à dire ma reconnaissance toute spéciale à ceux de mes collègues de la Faculté des Sciences sociales qui, à plusieurs reprises au cours de l'élaboration du volume, m'ont spontanément accordé leur encouragement, leurs conseils ou leur aide: MM. James Hodgson, Guy Rocher, Jean-C. Bonenfant, Albert Faucher et Maurice Lamontagne. Les critiques et les suggestions de MM. Lamontagne et Faucher m'ont été particulièrement précieuses pour la rédaction du dernier chapitre. Je m'en voudrais, enfin, d'oublier madame Pauline G. Côté et mademoiselle Renée La Rochelle qui, avec une égale bonne grâce, se sont partagé la fastidieuse tâche de la transcription des manuscrits.

La préparation de ce volume a été facilitée par une subvention du Conseil canadien de Recherche en Sciences sociales. Le même Conseil, auquel j'exprime ma très vive gratitude, a accordé une seconde et généreuse subvention au moment de la publication.

$$
\text { J.-C. F. }
$$




\section{AVANT-PROPOS}

\section{$\underline{\text { Retour à la table des matières }}$}

Ce livre est une symphonie inachevée, ou plus exactement, la narration polyphonique de l'histoire d'une société encore à la recherche d'elle-même. Il est né du centenaire de l'Université Laval, célébré en 1952. Parmi les manifestations de toutes sortes qui ont souligné cet anniversaire, une attention spéciale avait été accordée à des symposiums qui furent tenus à l'université même à divers moments de l'année académique. Ces rencontres scientifiques avaient comme objectif commun de discuter l'état actuel de la théorie et des recherches touchant certains problèmes fondamentaux des principales sciences de l'homme et de la nature. Des thèmes aussi variés que la conservation des ressources naturelles, les glandes surrénales, l'enseignement des humanités et l'évolution furent successivement abordés au cours de l'année par des savants et des experts internationalement réputés.

Le premier de ces symposiums eut lieu à Québec, les 6 et 7 juin 1952, sur Les répercussions sociales de l'industrialisation dans la province de Québec. Il coïncida partiellement avec le congrès annuel de la Société canadienne des Sciences politiques (Canadian Political Science Association) et groupa, en plus des quelque deux cents membres de cette société qui assistaient au congrès, des représentants de l'industrie et des grandes fédérations syndicales canadiennes, des professeurs de plusieurs Facultés de Laval ainsi que les porte-parole les plus autorisés des sciences sociales au Canada français. De l'avis commun, ces journées marquèrent un moment important dans l'histoire des recherches sociales au Canada et, de partout, on réclama que le bienfait en fût perpétué. Un grand nombre de personnes qui n'avaient pu assister au symposium manifestèrent le désir de prendre connaissance des travaux qui y avaient été présentés. Il convenait donc que le symposium devînt un volume. Le voici.

Pour que l'on comprenne bien la nature et la portée véritables de ce livre, précisons l'intention qui a déterminé l'objet du symposium et l'allure des chapitres qui suivent. Pourquoi d'abord ce sujet ambitieux ? Le sujet que nous nous étions proposé, ou mieux, qui s'était [p. 14] imposé à nous, « les répercussions sociales de l'industrialisation dans la province de Québec », 
correspondait éminemment à la préoccupation capitale des symposiums du centenaire de Laval. Il est un cas concret d'un ordre universel de phénomènes : celui du changement social. Or, quel problème s'impose de façon aussi insistante et aussi mystifiante à l'attention du spécialiste de l'une ou l'autre des sciences sociales que celui de savoir comment et pourquoi, à une période donnée, dans une société donnée ou dans un groupe de sociétés, il y a changement? Quelles questions plus intrigantes que de se demander: Quels sont les facteurs les plus décisifs de l'orientation et du tempo du changement social ? Quels sont les secteurs de la vie sociale qui acceptent ou subissent le plus facilement le changement? Quels sont ceux qui lui résistent? Quels sont, enfin, les éléments institutionnels qui font que, malgré le changement, un certain ordre social persiste et permet aux nouveautés de s'articuler aux systèmes anciens?

Ce sujet particulier répondait aussi pour nous à une préoccupation plus intime qui est au centre de notre labeur intellectuel : celle de comprendre la société canadienne-française d'aujourd'hui que notre université a la responsabilité d'interpréter, d'éclairer et d'orienter. C'est un lieu commun de répéter que la province de Québec s'est industrialisée et qu'elle est en état de transition. Aux alentours de 1890, lorsque Léon Gérin publiait la première étude scientifique sur le Canada français, la monographie de l'Habitant de Saint-Justin, la province comptait à peine deux ou trois centres de quelque importance; la population des villes ne formait pas même un cinquième du nombre total des habitants. Quelque cinquante ans plus tard, lorsque, vers 1940, paraissent les études d'Esdras Minville sur Notre milieu et le French Canada in transition d'Everett-C. Hughes, la population urbaine du Québec s'est accrue de plus de 500 pour cent, et l'on compte, en dehors du Montréal métropolitain, plus de 76 villes où un minimum de cent personnes travaillent dans les manufactures. La face de la province a changé. Mais toute société contemporaine est plus ou moins en voie d'industrialisation, en état de transition. Le Canada tout entier lui-même, de mois en mois, s'industrialise à un rythme frénétique. Ce qui rend d'un intérêt spécial le cas du Québec de langue française est que l'industrialisation s'y est inscrite dans une société homogène dont toute la structure était solidement intégrée par des institutions et des normes religieuses, dont l'histoire politique avait [p. 15] été orientée vers l'auto-défense, la lutte pour la survivance et la reconnaissance de ses droits de premier occupant d'un continent hostile, et dont l'idéal traditionnel en était un de fidélité à son paradis perdu.

Or, ce Québec industriel et urbain n'a encore été l'objet d'aucune étude d'ensemble. Un grand nombre de monographies ou d'essais ont été consacrés à des secteurs particuliers de sa vie juridique, économique ou politique, mais très peu relient les uns aux autres les phénomènes de ces divers ordres. Très rarement a-t-on scruté à fond l'un ou l'autre de ces problèmes particuliers; encore moins a-t-on considéré les uns et les autres dans leurs relations avec l'ensemble de la société. En d'autres termes, nous sommes encore à attendre des études qui identifient les caractères essentiels de notre société et qui aident à en prévoir le destin immédiat. Notre intention idéale était donc de tenter de brosser une fresque du Canada français contemporain et, pour autant, de 
proposer des hypothèses qui permettraient de l'interpréter valablement dans sa totalité et dans chacune de ses composantes sociales.

D'où, originalité et intérêt de notre entreprise, mais aussi, caractère forcément provisoire de la plupart de nos analyses. Pour atténuer cette témérité, nous avions jugé nécessaire de restreindre l'objectif de notre symposium à deux préoccupations essentielles : établir un inventaire de nos connaissances sur le Canada français contemporain ; éclairer les domaines que nous ignorons encore. Les travaux devaient d'abord faire état, à la lumière d'études existantes et de recherches originales, de ce qui est sérieusement acquis. En second lieu, et ce fut peut-être la principale raison d'être du symposium, nous voulions indiquer les recherches importantes qu'il reste à entreprendre. Nous estimions que notre effort serait totalement justifié si, au terme de nos discussions, nous parvenions à bien poser les bonnes questions.

La brève durée du symposium limitait à l'avance le nombre des communications possibles. Comme nous désirions que chacune de celles-ci fût suivie d'une analyse et d'une discussion générale, nous ne pouvions guère en prévoir plus de quatre par jour, soit, deux par séance, le matin et l'après-midi. C'est ce qui eut lieu: le symposium se réduisit à huit communications principales auxquelles s'ajouta, en guise de conclusion, une conférence publique du professeur Everett-C. Hughes de Chicago. Le choix du sujet particulier de chacune de ces communications fut établi d'après un plan d'ensemble élaboré durant [p. 16] l'année 1951-1952 par un comité de professeurs de Laval dont plusieurs étaient de la Faculté des sciences sociales. Ce plan prévoyait l'étude des principaux paliers de la vie sociale québécoise où des transformations notables sont survenues au cours des cinquante ou trente dernières années. Les huit communications devaient, en principe, après une introduction historique, nous faire graduellement passer du substrat matériel de la société à ses principaux cadres d'organisation sociale, et finalement, à ses formes spirituelles d'expression.

Les titres des chapitres de ce livre, dont la succession reproduit fidèlement la chronologie des communications du symposium, reflètent cet ordre général comme ils trahissent aussi, hélas, l'absence du grand nombre de sujets importants que le manque de temps nous empêcha de considérer. Ainsi, dans le cadre de ce plan, l'univers social qu'est l'agglomération montréalaise et qui constitue à lui seul presque la moitié de la province, ne devait être l'objet d'aucune étude exclusive. Aucun inventaire ne fut présenté de la structure économique et des ramifications internationales des industries québécoises contemporaines. Rien n'a été dit de l'expansion des industries secondaires ou des établissements de commerce et de service déterminés par l'accroissement des clientèles ouvrières et urbaines; ni des métamorphoses juridiques et financières des villes du Québec; ni des avatars de la langue populaire; ni de l'apparition d'un nouveau folklore associé aux occupations et aux modes de vie urbains; ni de l'importance et de l'influence dans la vie québécoise des groupes ethniques d'immigrants attirés par l'industrie et particulièrement concentrés dans certaines régions minières.

D'autres facteurs imprévus vinrent réduire encore le contenu de ce plan déjà comprimé. Les collaborateurs invités à présenter des communications au 
symposium furent choisis à cause de leur compétence reconnue et en tenant compte de notre ambition de faire de cette réunion une rencontre proprement œcuménique à laquelle coopéreraient des représentants du plus grand nombre possible d'universités québécoises, canadiennes et américaines. Bien que tous les collaborateurs invités, eussent accepté le plan général du symposium ainsi qu'une esquisse provisoire de leurs chapitres respectifs, chacun fut laissé entièrement libre d'aborder son sujet comme il l'entendait. Cette nécessaire liberté intellectuelle nous valut des travaux correspondant à toutes les variétés de préférences professionnelles et d'orientations méthodologiques. Quelques auteurs adoptèrent le style de l'exposé [p. 17] académique ; d'autres jugèrent nécessaire de décrire la méthode sur laquelle s'étayaient les conclusions de leurs recherches; d'autres préférèrent une esquisse panoramique à de minutieux dessins. En conséquence, et peut-être aussi parce que certains auteurs se méfièrent exagérément du danger des chevauchements et des redites possibles, des analyses importantes qui avaient été prévues dans le plan original furent escamotées en cours de route. Ainsi s'expliquent, sans se justifier, de nouvelles omissions qui vont surprendre sinon frustrer le lecteur, par exemple : qu'on ne fasse que de rapides allusions à la législation sociale et ouvrière ou à la réorientation du programme des partis politiques québécois à notre époque; surtout, que cette synthèse des conséquences de l'industrialisation dans le Québec ne contienne aucune étude traitant historiquement et systématiquement de l'évolution du syndicalisme dans notre province. On nous reprochera à bon droit d'avoir voulu présenter Hamlet sans le Prince ...

L'événement, néanmoins, fut d'importance. Les grandes lois du symposium furent celles de la liberté, de la franchise et de l'objectivité. Plusieurs s'affrontèrent et s'opposèrent. D'autres durent s'attaquer à des mythes populaires ou académiques. D'autres, enfin, durent rejeter, clarifier ou rectifier certaines analyses traditionnelles ou des clichés favoris. Il y eut aussi de remarquables coïncidences de diagnostic et d'interprétation. Les discussions générales qui suivirent chaque communication donnèrent lieu à des échanges d'idées dont aucun ne fut banal et dont certains eussent mérité d'être retenus par l'histoire. Rarement avait-on assisté à une rencontre d'hommes venus d'horizons intellectuels si divers discuter de façon si sereine, si franche et si pénétrante, la situation du Canada français.

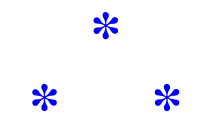

Tel fut le symposium. Plutôt que la fresque idéalement espérée, il offrit une série de tableaux discontinus, plus ou moins vifs en couleur, où les chercheurs à venir pourront choisir les scènes et les personnages qui les intéressent et en poursuivre l'histoire complète. Pour cette raison, ce volume se présente sous le titre plus modeste et plus réaliste d'Essais sur le Québec contemporain. Jusqu'à quel point est-il un reflet authentique du symposium ? Disons qu'il l'est dans toute la mesure où il fut possible de transposer en un 
ouvrage cohérent et de [p. 18] lecture facile des travaux originellement préparés par des auteurs divers pour présentation orale. Ainsi nous n'avons pas reproduit le compte-rendu des discussions générales qui ont suivi chaque communication durant le symposium. Le livre en eût été intolérablement alourdi. Le fait d'imprimer en blanc et noir une discussion spontanée enlève à celle-ci sa saveur et son intérêt. Ce qui avait été un dialogue pétillant, animé, devient un monologue interminable.

On trouvera dans ces pages seulement des travaux de deux ordres : en premier lieu, sous formes de chapitres, les essais élaborés qui constituaient les communications fondamentales du symposium; à la suite de la plupart de ces chapitres, des commentaires. On avait, avant le symposium, soumis le manuscrit de chaque communication à un spécialiste en l'invitant à en faire une analyse critique. Ces analyses étaient destinées à assurer une impartialité et une objectivité aussi grandes que possible et à situer les discussions dans une généreuse perspective. Aussi bien, beaucoup de ces commentaires proposent une documentation et des interprétations originales qui complètent heureusement les essais fondamentaux et s'élèvent à la hauteur de contributions scientifiques d'intérêt durable. Ils sont un élément essentiel de la tentative pirandellienne que fut le symposium.

On s'étonnera peut-être du fait que ce livre contienne des chapitres en français et en anglais sans traduction ni des uns ni des autres. Il en est ainsi par souci de fidélité au symposium lequel, par nécessité et par principe, dut revêtir un caractère bilingue. Il s'adressait à un auditoire venu de tout le Canada et devait permettre une communication aussi spontanée et aussi complète que possible. Comme l'auditoire du premier jour, celui de la Société canadienne des Sciences politiques, était en très grande majorité anglophone, tous les travaux de cette journée, y compris ceux des collaborateurs de langue française, furent présentés en anglais. La seconde journée, à l'inverse, fut presque exclusivement française, même la séance finale. Nous reproduisons les textes tels qu'ils furent présentés, convaincus qu'une telle alternance des deux langues dans le même ouvrage constitue une excellente formule de bilinguisme, peut-être celle qui répond le plus élégamment aux désirs et à l'idéal de la vie académique canadienne du moment.

Le texte de chacun des chapitres et de chacun des commentaires est en substance celui qui fut lu au symposium. Chaque auteur, cependant, a eu le privilège de revoir et de corriger son manuscrit. Quelques-uns des manuscrits furent légèrement remaniés ou condensés. Dans [p.19] certains cas, les auteurs se sont permis d'ajouter à leur texte des références à des études parues depuis juin 1952. Dans tous les cas, on a apporté les corrections de dates qui s'imposaient pour rendre intelligible un ouvrage publié plus d'un an après sa rédaction initiale. Chaque chapitre et chaque commentaire a son style et son orientation propres. L'unité de cet ouvrage lui vient, au-delà des points de vue et des accents particuliers, d'un souci collectif de vérité et de sérénité. C'est dans le but de concrétiser cette unité qu'on a tenté, dans un chapitre inédit sous forme d'épilogue, de dégager et de raccorder les fils de la trame qui s'élabore progressivement tout au cours de ces études. Le lecteur ou le chercheur éventuel trouveront dans ces dernières pages un rappel aussi cohérent que 
possible des principaux thèmes du symposium et des modulations qui les relient les uns aux autres.

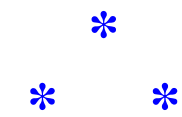

Le titre de cet ouvrage, de même que toutes les réflexions précédentes, indiquent suffisamment en quoi consiste le cadre géographique et social auquel sont consacrés ces essais : c'est exclusivement la province de Québec. On remarquera que la plupart des auteurs emploient indifféremment les expressions «province de Québec » ou « Canada français ». Nous savons que cette identification n'est pas tout à fait juste puisque l'expression "Canada français », au sens strict, peut s'entendre de toutes les régions canadiennes, des provinces maritimes jusqu'à celles de l'Ouest, où se retrouvent des populations de langue française. Néanmoins, un usage populaire, répandu surtout parmi nos compatriotes anglophones et historiquement justifié, restreint le terme « Canada français » au Québec. C'est le sens qu'il faudra ici lui sous-entendre. Notre recherche porte sur le Québec en tant qu'habitat principal, historique, de la société canadienne-française.

Ajoutons un dernier éclairage méthodologique. Le phénomène de l'industrialisation s'accompagne universellement d'un autre phénomène qui est celui de l'urbanisation. Dès que, dans un lieu, s'établit une usine ou une fabrique, des ouvriers s'y concentrent et une communauté de caractère urbain s'organise ou se précise. C'est d'abord sous forme de villes et ensuite à l'intérieur des villes que se révèlent les changements sociaux entraînés par l'industrie. Les deux phénomènes, industrialisation, urbanisation, sont quasi indis-[p. 20] sociables, au point qu'un grand nombre de métabolismes souvent imputés à l'industrie sont les sous-produits de la vie urbaine en tant que telle. Néanmoins, ils se différencient spécifiquement: industrialisation se dit de transformations d'ordre technologique alors que l'urbanisation définit une évolution d'ordre culturel. Bien qu'il soit malaisé de déterminer ce qui, dans l'ordre social, dérive causalement de l'un ou de l'autre phénomène, nous avons tâché, dans ces essais, de maintenir une distinction entre l'un et l'autre. Le phénomène sur lequel nous concentrons notre attention en tant qu'élément causal de transformations sociales est celui de l'industrialisation.

Ce concept d'industrialisation lui-même, qu'il soit employé de façon populaire ou scientifique, comporte un grand nombre de connotations. Essentiellement, il signifie un processus de changements, brusques ou graduels, dans les techniques d'exploitation des ressources, agricoles ou autres, de la nature. L'industrie moderne, telle que nous la connaissons, met en œuvre une technologie raffinée qui exige à la fois une mécanisation extrême et une utilisation purement pragmatique, dite rationnelle, des hommes qui manipulent ou contrôlent les instruments de production. De façon dérivée, l'industrialisation signifie donc aussi la mobilisation d'une nombreuse maind'œuvre spécialisée, l'absorption de celle-ci par les diverses catégories 
d'entreprises industrielles, sa hiérarchisation d'après les degrés de la technique, en un mot, la création d'un univers social de type particulier, fondé sur une nouvelle division du travail social et dont la structure reproduit, en l'amplifiant, la structure bureaucratique de l'usine. Une autre caractéristique de l'industrie moderne, comme le note le professeur Hughes au chapitre X, est qu'elle s'établit en général dans un pays par mode d'invasion, en ce sens que le capital, l'outillage et les techniques nécessaires à l'industrie sont apportés dans ce pays par des gens de l'extérieur. Ceux-ci sont, la plupart du temps, d'une nationalité et d'une culture différentes de celles du pays où ils pénètrent et ainsi une invasion industrielle s'accompagne presque invariablement d'une invasion culturelle. Tout processus d'industrialisation implique, en plus de transformations technologiques et morphologiques, des perturbations d'ordre spirituel et moral.

On sait avec quelle évidence souvent pathétique ces problèmes se sont imposés à l'attention universelle depuis la fin de la deuxième guerre mondiale, à l'occasion des programmes d'aide matérielle aux pays dits attardés ou sousdéveloppés. Les expériences de l'application [p. 21] du « Point Quatre » ou de l'Assistance technique des Nations-Unies nous ont rappelé que le transfert de la technologie d'une civilisation donnée à des pays de civilisations différentes n'est pas un simple phénomène économique. Il met automatiquement en cause des facteurs sociaux, culturels et politiques. Déjà une littérature scientifique abondante et des recherches nombreuses, en particulier celles qu'a inspirées l'UNESCO, se sont préoccupées de reconsidérer ce phénomène multiforme dans une optique qui se veut globale. Il nous reste à souhaiter que cet ouvrage, en plus d'aider à mieux comprendre notre société, ajoute aussi à sa façon une contribution utile à la compréhension de problèmes qui se posent à l'échelle mondiale.

Jean-C. FALARDEAU

Faculté des Sciences sociales, Université Laval.

Août 1953. 


\title{
CHAPTER I
}

\author{
HISTORY OF INDUSTRIAL \\ DEVELOPMENT
}

\section{Albert Faucher et Maurice Lamontagne}

\section{$\underline{\text { Retour à la table des matières }}$}

An analysis of the social impact of industrialization in Quebec, like this symposium, should be seen against abroad historical background. Accordingly, this first chapter will deal with the time-space aspects of certain potent factors in the evolution of Quebec's industry. Due to the scarcity and, in many instances, the complete absence of statistical data, our approach has to be non-quantitative. On the other hand, scientific investigation of this topic has been scanty. Hence the interest as well as the difficulty of mapping a pioneer exploration on such unchartered seas while raising questions conducive to further inquiries into, and to more elaborate interpretation of Quebec's economic development during the last century.

An interpretation of long-term industrial changes in Quebec is nonetheless possible. At the outset, one is reminded of the frequent statement that this province has been very slow in developing its industrial structure in comparison with other regions in North America. The statement is true, if one refers to the longest phase of our economic history, up to 1939. During the century 1839 to 1939, employment in manufacturing industries in Quebec rose by only a little more than 200,000 . Yet, one must then immediately realize that Quebec has experienced an employment increase of exactly the same magnitude during only the short space of time between 1939 and 1950. Its relative industrial growth, during these last eleven years, has been ten times as great as what it had been during the preceding century and higher than that of Canada as a whole.

In what term must such a development be interpreted ? The most frequent interpretation suggested is that Quebec's relative economic «backwardness » 
is chiefly related to the influence of specific cultural factors. But, is such an interpretation justified? [p. 24] If it is, it would be rather difficult to account for the recent rapid growth, unless cultural forces are assumed to have undergone a profound change in orientation. We submit that this explanation does not seem acceptable. Cultural forces have not changed their direction and if, during a certain period, our economic evolution seems to have been determined by their influence, it is because it could not follow any other course at that particular time.

The explanation of industrial development propounded in this study is quite different since it refers mainly to economic and geographical factors. Our postulate is that one cannot understand this evolution without constant reference to the location factors prevailing in each period and to the elementary fact that Quebec is part of the North American continent. The study covers the last century and is divided into two parts concerned with two characteristic stages of our industrial evolution.

\section{PERIOD OF SLOW DEVELOPMENT : 1866-1911.}

The first period begins during the sixties of the nineteenth century. In order to understand the subsequent evolution, one must review briefly the situation which prevailed during that period.

This early or pre-industrial period can be identified with the commercial era. Its upward trend started at the beginning of the nineteenth century, with the Napoleonic wars. The two main articles of commerce were wood and grain and the main points of economic development were located along the Atlantic seaboard. In the United States, Boston, New York, Philadelphia and New Orleans were very active and were in a position to develop some consumers' goods' industries.

During the same period, Quebec was leading the way in Canada, its economic development being centered around Quebec City and Montreal. Thus, the historical prominence of Quebec in the development of Canadian economic life coincides in this era with a phase of commercialism and is due to the economic significance of the St. Lawrence waterway ${ }^{1}$. Apart from providing easy access inland and permitting new settlements along the lowlands and the [p. 25] river valleys, the St. Lawrence was primarily a commercial route supporting a traffic system, a sort of water-spout to the upper areas. From this function, the lower stream areas derived their prosperity. Quebec City, in particular, experienced a very active commercial life completed by a rapidly developing industrial structure resting mainly on shipbuilding. Economic and geographical factors were favouring that region

D. G. CREIGHTON, The Commercial Empire of the St. Lawrence 1760-1850, Toronto, Ryerson, 1937 ; A. R. M. LOWER and H. A. INNIS, Select documents in Canadian economic history, 1788-1885, Toronto, The University of Toronto Press, 1933. 
and the population tried its best to profit from its advantageous position. Thus, during this early period, Quebec did not have a behaviour of its own. Its cities, like other North American seaboard centers, participated very actively in the prosperity brought about by commercialism.

A series of factors were to bring this period to an end and to disrupt the old arrangement : free trade in England, the end of our Reciprocity treaty with the United States ${ }^{1}$, the deepening of the St. Lawrence and the construction of the canals. Undoubtedly, the, most important factor which accompanied the passage from commercialism to industrialism was the substitution of steel for wood as the basic economic product of industry and the construction of the railroads was the decisive element in this change. In the shipbuilding industry, the shift was made possible by the introduction of the steam engine. Thus a new era was beginning during which coal and iron would be the primary factors conditioning economic development. Thereafter, only those regions where coal could be found would experience rapid progress ${ }^{2}$.

These technological improvements implied a change in the relative importance of the locational factors and a displacement of the center of economic gravity in North America. In the United States, during this first period of industrialism, the seaboard cities producing mostly consumers' goods passed to a rank of second importance. New York was the only exception because of railways converging thereto as toward a year-round seaharbour and a financial center. Boston and Philadelphia receded and lost much of their strategic importance. With the iron age, the Appalachian coal fields were to assume a significant role. Pittsburgh emerged as a steel city to be linked later with the Minnesota iron range.

[p. 26]

These changes had their counterpart in Canada. The seaboard cities lost their locational advantages resting on the old commercialism and Quebec was deprived of its prior importance as a land of lumbering and shipbuilding. The President of the Board of Trade in Quebec City summarized the situation as follows : "At one time, our great industry in Quebec was shipbuilding, in which trade we then excelled. This branch of industry gave employment to a well trained and hardy race of carpenters. It was a fine sight during those winter seasons to see our shipyards booming with the sign of life and activity... Unfortunately, with the progress of science and civilization, this industry, which was that upon which we chiefly depended, had to make way for more modem necessities ${ }^{3} \gg$. Without coal and iron and without technological know-how in the iron works, " the hardy race of carpenters » was confronted with a lay-off.

A. R. M. LOWER, The North American assault on the Canadian forest, Toronto, Ryerson, 1938, cc. XIII-XIV.

2 J. R. SMITH North America : its people and the resources, New York, Harcourt, Brace \& Co, 1940 ; C. L. WHITE and E. J. Foscue, Regional geography of Anglo-America, Prentice Hall, 1950.

Address of Joseph Shehyn Esq. M.P.P., Feb. 1880, p. 24. 
In Canada as well as in the United States, economic activity moved toward the center of the country. In this new region of industrialism, southern Ontario was strategically located with respect to water-borne and railway traffic. It was adjacent to the Appalachian coal fields and could command the cheapest routes to the western hinterland. To these advantages was added a decisive factor, the tariff walls which according to geographers played « a vital role in causing manufacturing to be more important on the Canadian side than otherwise would be the case ${ }^{1}$ ». Thus the Great Lakes sub-region of Ontario emerged as the Canadian wedge into the United States and forged ahead in stride with the Pittsburgh-Cleveland sub-region of the manufacturing belt. The importance of tariffs in this development cannot be too much emphasized. In the words of Bruce Hutchison, the wedge " is physically almost an island surrounded by lake and river. Economically it is still more insular behind a chinese wall of tariffs ${ }^{2} \gg$.

Thus the decadence of Quebec's economic prominence was not a regional incident. It was a much wider phenomenon which affected the whole continent and which was due to the passage [p. 27] from a regime of mercantilism to a system of industrialism based upon coal, steel and steam.

Within the new industrial arrangement which emerged, Quebec was not in a position to develop an industrial economy. The only locational advantage which remained was a surplus of labour, either left over or drawn from the countryside and in any case peaceful and dependable. Yet this advantage was not important because labour could always move. Nonetheless, Quebec had, like New England, to adapt itself to the new situation and the two regions followed the same solution, which probably was the only possible one in any case. Quebec joined in with the "sweating-system» industry belt of the continent at the time when Ontario was related to the tool-producing and steel industry belt.

At that time, there did exist mining quarries in Quebec, especially in the Eastern Townships, where asbestos mining began in 1877. This industry developed slowly, producing 10,000 tons in 1895 and employing 700 workers : but it was only after the first decade of this century that it embarked upon large scale operations to contribute more than 70 per cent of the world's production.

In fact, however, the early industrial era in Quebec was to rest on shoe factory, textile mills, sawmills and some railway rolling-stock milling in Montreal. It is interesting to note that most of these industries were to a large extent artificial in the sense that like those of Ontario, they needed tariff protection ${ }^{3}$. The boot and shoe industry emerged in 1847 in Montreal and in the mid-sixties in Quebec City, and attained a position of dominance in the early eighties. In 1880, the famous Bresse shoe factory could turn out as many

C. L. WHITE and E. J. FOSCUE, op. cit., c. XIII.

Bruce HUTHCHISON, The Unknown Country, c. VII, Toronto, Longmans, 1948.

It is well known that iron works in Montreal were developed because of federal subsidies to coal movements from the Maritimes. 
as 3,000 pairs of shoes per day. At the end of the century, no less than 3,000 workers were employed in the industry in Quebec City alone ${ }^{1}$.

The textile industry also was rapidly growing, especially, in the last quarter of the century. Mills were, established in Valleyfield in 1874, Montreal in 1875 and 1882, Coaticook in 1879, Chambly in 1881, Magog in 1884 and Montmorency Falls in 1889. Several of these mills were merged and in 1905, Dominion Textile Company became the leading concern. The Whitehead interests were estab-[p. 28] lished in Three Rivers in 1907 and in Shawinigan Falls in 1909. At that time, the industry provided employment to over 8,000 workers in the province ${ }^{2}$.

In general, it is noticeable that the manufacturing pattern of the thirty-year period extending from 1881 to 1911 rests mostly on miscellaneous materials, vegetable and animal, and especially on textile, leather, log and lumber products. Throughout the period, the relative importance of the groups comprised in the pattern remained about the same, with the exception of shoemaking which somewhat declined after 1900, owing to rising costs of labour. It is useful to emphasize that such an economy developed against background of tariff and cheap labour. As for the economy as a whole, it was predominantly agricultural at the end of the century. On the basis of a total production estimated at $\$ 150,000,000$, agriculture contributed 65 per cent, forestry 25 per cent, manufacturing 4 per cent, fishing and mining about 2 per cent respectively.

Thus, Quebec lived through a long period of profound disequilibrium. At the time when its industrial structure experienced a crisis of adaptation and was developing very slowly, its population tended to increase at a fast rate. Its birth rate has been paralleled with that of Rumania in the early part of this century, as indeed it could have been in the nineteenth with that of the most prolific nations of the western world ${ }^{3}$. It was, beyond any doubt, the outstanding feature of the Quebec community at that time that it would so rapidly multiply with so little opportunity for commercial or industrial employment. This phenomenon, which had cultural origins, was to carry important economic implications.

This natural growth, higher though it may have been than the growth of capital accumulation, did not disquiet authorities, State and Church alike, who rather encouraged further proliferation. A solution to the disequilibrium had to be found, however. The only possible answer, at the time, was the encouragement of agriculture and colonization because there was no other opportunity for employment. Thus agricultural expansion coincided with the teachings of a traditional philosophy of rural life ; but it cannot be said that it resulted from these teachings: there was nothing else to do. In any case, colonization societies were organized. Duver-[p. 29] nay's slogan: «Emparons-nous du sol » was resumed so as to give it a definite connotation of nationalism : « Emparons-nous du sol, c'est le meilleur moyen de conserver

SHEHYN, op. cit.

Rapport de la Commission royale d'enquête sur l'industrie textile, Ottawa, 1938.

Statistical Year-Book, Province of Quebec, 1914. 
notre nationalité ${ }^{1}$. \ Agriculture was made functional to nationalism - or to religion, as stated by a curé at the time: «The road and the chapel together are colonization $^{2}$. »

As early as 1820, however, agriculture had occupied the best arable land ; with the exception of the Lake St. John and Abitibi regions, it had reached its optimum point of expansion covering the St. Lawrence lowlands and the arable patches of river valleys ${ }^{3}$. The stony and boulder-strewn areas of the St. Maurice, Mattawin, Maskinongé, as also those on the table-lands of the Etchemin and Chaudière, not to cite those in the midlands of the Lower St. Lawrence region, should in the opinion of experts, have been kept forested. This is not to say, of course, that agricultural expansion over those areas did not fulfil any function, but rather to suggest that they could have served some alternative use in a more efficient manner.

The possibilities of agricultural expansion were much too limited to fill the gap between the rate of population growth and the rate of industrial development, so that large-scale emigration became a necessity. The surplus population could not easily move toward Ontario because the absence of technical knowledge in iron works would have made it very difficult to find employment there. On the other hand, New England needed additional manpower for its labour force was moving to the East-Central states. This was precisely the direction which the majority of Quebec emigrants followed. It is estimated that about half a million people left Quebec for New England in the second part of the last century ${ }^{4}$.

From the above considerations, it can be inferred that the economic evolution of Quebec during the 19th century has been primarily conditioned by geographical and economic factors [p. 30] inherent in the North-American system of political economy. During that period, Quebec was closely associated with New England and had a similar economic fate. Both these regions had played a leading role in the times of commercialism; with industrialism, New England lost its economic prominence to the East-Central states and Quebec to Ontario. Finally, the two regions reacted in the same way to economic change, that is, by concentrating on labour-oriented industries. Cultural factors had nothing to do with that evolution and with the relative lethargy of Quebec's industry in comparison with that of Ontario: this difference is explained by the simple fact that Quebec, in the steel economy of that period, had no coal and no iron and was located too far from the Appalachian coal fields.

The only phenomenon which was specific to Quebec was its population problem. Agricultural expansion and emigration were the only possible

Le Canadien émigrant, par douze missionnaires des townships de l'Est, Québec, 1851.

Questionnaire, in Report of the select standing Committee on agriculture, immigration and colonization, Journals of the legislative assembly of the Province of Quebec, 1867-68.

J. BOUCHETTE, Topographical dictionary of the Province of Lower Canada, London, 1832 ; Georges VATTIER, Esquisse historique de la colonisation de la province de Québec (1608-1925), Paris, 1928.

4 G. LANCTÔT, Les Canadiens français et leurs voisins du sud, Montréal, Valiquette, 1941. 
solutions. That is why at the end of this period Quebec was primarily agricultural not by choice but through sheer necessity. Another feature of Quebec's economy was that its industry, with the exception of sawmills, was not based upon the exploitation of its natural resources, but on cheep labour and on the exploitation of the consumers' market. That is why it needed tariff protection to survive and it was mainly dependent for its prosperity and expansion upon the agricultural sector which provided the market. This last feature was quite paradoxical for a region which was not naturally destined to be agricultural.

\section{THE NEW ERA OF INDUSTRIALIZATION}

With the beginning of the present century, new trends appeared in the Quebec economy. Again, this region remained closely associated with the North-American continent, but, for the first time in its history, it showed a profound difference in behaviour from New England. During the period of commercialism, our economic evolution had paralleled the development of the United States ; in the early phase of industrialism, Quebec had to fight for its survival against the pervasive economic influence of the East Central States. With the new era, it was definitively integrated with the North-American system and its economic development was based upon the resource pattern of the whole continent. [p. 31] In other words, Quebec's natural resources were called upon to fulfil a definite function and a specific need. While the development of Southern Ontario had been a mere counterpart of American industrialization, Quebec's industrial growth was designed to complement it.

Several factors are at the origin of the fundamental change which was about to happen in Quebec's economic picture. First, and perhaps the most important, was the depletion of certain resources and the insufficient availability of other factors in the United States ${ }^{1}$. Pulp-wood, copper and iron are good illustrations of this situation. Secondly, steel kept its prominence, but lost some of its relative importance or other metals were used as substitutes in several fields. Moreover, aircraft did for aluminum what the railroads had done for steel. Thirdly, coal receded from its dominant position as a source of power and water became a cheaper substitute. Thus hydro-power exerted an increasing locational pull for new industries.

As can be readily understood, this evolution involved deep changes in the relative importance of the locational factors and, this time, Quebec was strongly favoured by the new orientation of economic development. In order to understand why, it must be realized that the Precambrian Shield, which is

J. A. GUTHRIE, The newsprint paper industry, Cambridge, Harvard University Press, 1941, c. II ; ELLIOTT and others, International control in the non-ferrous metals, The Macmillan, N. J., 1937, Part II ; D. H. WALLACE, Market control in the aluminum industry, Cambridge, Harvard University Press, 1937. 
the dominating feature on the map of this continent, comprises about eighty per cent of Quebec's territory. This huge expanse of land which lies north of the St. Lawrence (and which long remained foreign to the ruralist wing in this land of Quebec) had derived its early significance from fur trading and lumbering. Later on, with the decline of these trades, it receded from this pristine importance to a position of nuisance. It was qualified as a liability by railroad promoters. For the reasons already indicated, the old industrialism did not work out the economic integration of the Precambrian territory with what was then known as Quebec's mainland. The rugged Shield remained mysterious and, for the casual observer, comprised a useless expanse. With the new era, however, it was gradually realized that the so-called liability contained immense [p. 32] forest resources, rich mining deposits of all sorts and tremendous potential of hydro-power. The new industrialism would effect the economic integration of the Precambrian territory with the NorthAmerican continent.

In choosing the year 1911 as a dividing line between the first and second phase of industrialization, it should not be thought that Quebec immediately assumed the aspect of an industrial landscape. The new orientation had already started before that date and was to develop slowly except in the 1920's and since 1939. Throughout the first two decades of the century, the course of economic events offers little to suggest that labour-oriented industries alone had altered Quebec's industrial structure. It was only when a number of material and/or power-oriented industries were married to the polygamous hydro-electric concern and when the two processes, old and new, joined together in the upswing of the 1920's that industrialization did challenge Old Quebec. This recent trend, capped as it was by a tremendous war and postwar expansion, has been spectacularly magnified in the last decade.

It should also be emphasized that in this new evolution Quebec, quite naturally, lagged behind Ontario because of its previous period of stagnation and its less favourable geographical position in respect to the industrial belt of the United States. As early as 1900, the Ontario Government put an embargo on export of pulp-wood to the United States which obliged Americans to build new plants in that province. Quebec arrived at the same decision only in 1910. Quebec also shared with Ontario in respect to metal, mining and refining, but after a much more considerable lag. In Ontario, mining discoveries were made at Sudbury and Cobalt in the course of railroad construction. Then Cobalt supported expansion toward the clay belt into the Porpicune and Kirkland Lake areas ${ }^{1}$. From there, mining operations extended to the Quebec gold belt where the first strikes were hit before the building of the railroad. Thus, for various reasons, the occupation of the Precambrian area in Ontario and in Quebec represent two distinct phases of economic expansion, but, for the first time, both developments were moving in the same direction and they responded to the same American impulse.

[p. 33] The main events of the new era in Quebec are too well known to necessitate a detailed account. Its first signs appeared with the emergence of

H. A. INNIS, Settlement and the mining frontier, Toronto, Macmillan, 1936, cc. VII-VIII. 
what has been called the twin industry, that is, hydro-electricity and pulp and paper. Then came the aluminum, the mining, the chemical and the aircraft industries. The changes which occurred during this period can be measured by a comparison of the relative importance of the industrial groups between 1920 and 1941. In round figures, agriculture, in 1920, contributed 37 per cent of Quebec's production, and manufacturing 38 per cent. Next came forestry with 15 per cent, construction 4 per cent and mining 3 per cent. In 1941, the position of these groups was respectively : manufacturing 64 per cent, forestry 11 per cent, agriculture 10 per cent, and mining 9 per cent.

Although this comparison between 1920 and 1941 reveals decisive changes in the industrial structure and a rapid progress toward industrialization, the period of fastest development has been the last decade. The following statistics, prepared by the Department of Trade and Commerce in Ottawa, sum up the story. As was already stated at the beginning of this study, employment in manufacturing doubled from 1939 to 1950. This increase, in absolute terms, is equal to the growth witnessed during the whole century ending with 1939. In addition, during this last decade, gross value of production doubled in real terms, while investment tripled. Out of every ten people looking for work, in 1939, 1.5 could not find a job, while in 1950 unemployment was negligible. Before the war, 2.5 persons worked on farms, but now only 2 are engaged in farming. During the same period, employment in cities, towns and villages increased from 6 to 8 . Of these, three persons at the two dates were employed in commercial, financial and service occupations. Three persons found employment in industry in 1939 and 5 in 1950. Of these, one person worked in primary industries at the two dates, but employment in manufacturing, electric power and other utility undertakings rose from two to four persons ${ }^{1}$. The chief contributions to the rising importance of manufacturing were, by order of relative importance, electrical apparatus, transportation equipment, wood products, iron and steel, pulp and paper and primary textiles.

[p. 34]

During the period under review, the rate of industrialization in Quebec has been higher than that of Canada as a whole. Since 1939, in volume terms, output of manufacturing industries rose by 92 per cent in Quebec and by 88 per cent in Canada, while new investment in manufacturing increased by 181 per cent in this province and by only 154 per cent in the whole country ${ }^{2}$. Similar statistics for the other Canadian provinces are not readily available to permit comparisons at this level. The rate of development for Ontario is probably still higher than it is for Quebec, but if there is any difference, it is certainly much smaller than it was during the previous decades. If we now look into the future, it is evident that Quebec's prospects are excellent. If we consider only its immense area and the amount of its natural resources not yet exploited, it would not be surprising if its rate of long term development would become the highest in Canada before long. During the period of

See chapter II, infra, Recent industrial growth, Table 3.

Ibid., Table 4. 
expansion toward the North, Quebec may well regain the supremacy it had lost in the course of the development toward the West. This forecast assumes, of course, that economic trends will not be tampered with by political or other factors.

\section{CONCLUSION}

In concluding we must recall again that this study was intended to describe industrial development in Quebec in such a way as to permit an analysis of its social implications. The main attempt has been to show that Quebec's industrialization had nothing specific to do with, and was not fundamentally influenced by its cultural environment; that, rather, it was a mere regional manifestation of the overall economic evolution of the North-American continent.

It is the task of the other contributions to this symposium, to investigate how industrialization has altered the cultural pattern and has changed the orientation of social institutions. In view of those contributions, it seems fitting to stress the main features which can be gathered from the historical introduction.

First, Quebec's industrial development has been North-American. Quebec's economy has never behaved in an autonomous and isolated way. On the contrary, it has always felt very deeply the impact [p. 35] of the NorthAmerican evolution. Its development has been mainly a response to change affecting the whole continent. Thus conceived as a part in a larger unit, Quebec cannot be said to be backward or forward economically. In an economy of coal and steel, when the locational factors were not favourable, it developed less rapidly than other regions in a more advantageous position. On the other hand, when these factors became favourable, progress was immediately felt.

Secondly, Quebec's development is now based upon its natural resources and no longer on cheap and "reliable» labour as some propaganda would have us believe. In the early phase of industrialization, as we have seen, the main types of industries were labour-oriented and produced consumers' goods ; industrial expansion depended to a large extent upon the agricultural sector which, for that very reason, could not progress. Today, the situation is reversed. Economic development is now focussed around several basic industries exploiting the natural resources of the Precambrian Shield. In this industrial sector, labour is not cheap ; it is not even always reliable according to some employers. In spite of that, this care of new industries has become the dynamic element in Quebec's economy. Its influence is deeply felt by the old types of labour-oriented industries and agriculture is now dependant upon the industrial sector. Thus a new equilibrium is being worked out which will rest much more than the old one on Quebec's natural advantages.

Thirdly, Quebec's expansion is characterized by large-scale and monopolistic industries. In most cases, large-scale operations were required by 
technological conditions; pulp and paper, aluminum and aircraft industries are good illustrations of this situation. In a lesser number of cases, they can be explained by the potentialities of the market and by the desire for bigness. However, economic power is much more concentrated than the size and the number of plants would lead us to believe. All kinds of methods have been used to create monopoly power and even the group of old industries such as textiles, shipbuilding, tobacco and breweries has participated in the movement toward higher concentration. Thus it is more and more difficult to enter into established industries.

Finally, industrialization has not been a realization of the main ethnic group in this province. In view of the purpose of this [p. 36] study, this is a very important feature of Quebec's economic development. It is very difficult to get good estimates on the importance of foreign investments in this province and reliable information concerning foreign control in the different industries. Very often legal arrangements contribute to conceal the true economic relationships.

It is possible to say, however, that American ownership and control are widespread. The erection of American subsidiaries in Quebec can be traced to the early years of Macdonald's national policy. Up to 1900, 25 American firms established branches in the Quebec territory. It has been estimated that during the next fifteen years, 43 per cent of the investments in new facilities came from the United States. It is reported that in 1934, a third of the capital invested in Quebec was American. This trend may well have been strengthened during and after the war. Projects now under way to exploit titanium iron deposits at Allard Lake and iron ore in what has been called the "New Quebec » indicate that the flow of American capital into Quebec is still very strong. This movement is explained first by the fact that early industrialization in the United States had permitted the creation of a large reserve of capital. Part of this capital, in turn, was invested in Quebec because the Americans needed our natural resources or looked for an access to a protected Canadian market.

This does not mean, however, that the Americans have been the only ones to finance and direct Quebec's industrialization. Even Ontario has made its contribution, mainly in the mining industry. It remains true, however, that economic development in Quebec has been financed, directed and controlled from the outside. From this point of view, it can be said that this province suffers from absentee ownership and entrepreneurship.

Another outstanding fact is that French Canadians in particular have played a minor role in the field of industrial development. Up to now, this fact has been explained mainly in cultural terms. A discussion of such an explanation would lie outside the scope of this paper. We would like to submit however that its soundness has been too readily accepted and that inadequacies of our educational system cannot very well account for the situation, because it is well known that successful businessmen in French Canada as elsewhere, at least in the past, were not necessarily university [p. 37] graduates. It has also been alleged that our cultural characteristics were responsible for our lack of interest in business matters or were incompatible 
with large scale enterprise. We would suggest to sociologists to look for a more materialistic and commonplace explanation and to go back to economic realities both past and present.

Finally, it must be pointed out that in such a system where absentee ownership and entrepreneurship prevail, administrative functions have been delegated to a local management with limited responsibilities and predominantly English-speaking. This situation creates serious problems, especially in labour relations. In this field where the human aspect is so important, economic conflicts tend to be aggravated by ethnic tensions. These conditions are apt to breed such grievances as were expressed by the voice heard by Maria Chapdelaine forty years ago : " Strangers have surrounded us whom it is our pleasure to call foreigners; they have taken into their hands most of the rule, they have gathered to themselves much of the wealth ; but, in this land of Quebec, nothing has changed. »

Nothing has changed, indeed, for the core of French Canada has remained the same. It may be asked, however, what actually constitutes the core of French Canada, but it is the task of sociologists to answer the question. The message gathered by Maria Chapdelaine further reads: "In this land of Quebec naught shall die and naught shall suffer change. »

How, and to what degree may this land of Quebec have suffered change in the last forty years and to what extent can it be further modified? For some changes have to be introduced in order to keep the nationalistic resentment from being transformed into a fight against capitalism. This paper may have shown from the basic standpoint of economy and geography that some change has been introduced into Quebec and is presently being introduced. Still, the question is being asked whether social institutions have been able to go ahead or keep abreast of the change. The voice of Peribonka echoes now as a challenge to the spirit of scientific investigation and it suggests that perhaps, in the last forty years, more change has been wrought over this land of Quebec than many local philosophies may dream of. 


\title{
COMMENTS
}

\author{
O.J. Firestone
}

\section{$\underline{\text { Retour à la table des matières }}$}

This introductory essay is a penetrating analysis of a vital aspect of the development of the Province of Quebec : how a region, with as bountiful and diverse resources as this province, for many generations led a life of tranquility until, with the beginning of the twentieth century, the powerful forces of new industries on the march began to transform a largely pastoral and commercial economy into a community rapidly advancing in technology and bursting with energy and drive. Far from having spent itself after half a century of industrial expansion, there pulsates today through the width and breadth of Quebec's economy an inbounding vitality and innate creativeness which holds bright promise for greater economic achievements in the next half century.

The authors of this chapter have provided us with a very helpful perspective of Quebec's industrial development. They have pointed to both the strength and weaknesses inherent in Quebec's industrial structure, and thus have given us a sound basis for concluding that Quebec's economic future is bright indeed, notwithstanding the handicaps of ever-changing markets and human attitudes. I would rank this paper as an historical document worthy of Laval's centenary celebration.

The way in which it takes stock of Quebec's economic progress and points to the potentialities that appear to exist reminds me of a set of documents with a similar purpose written close to 300 years ago, about the time when the Seminary from which this University grew was founded : the reports of JeanBaptiste Talon, one of France's foremost emissaries to the infant colony of New France. He, like many others after him, was greatly impressed by the vast resources that were awaiting development and the great possibilities that appeared open to the enterprising and the imaginative individual. New France might have had a population of only 3,200, but Talon's enthusiasm knew few limits. In trying to fire the imagination of France's rather hard-to-impress Minister of Finance, Colbert, - Ministers of Finance do not seem to change much over the ages - he wrote in October 1665, shortly after his arrival, that New France had foundations upon which might be [p. 39] built, « an empire, or at the least a powerful nation » (free translation). Perhaps, however, even an 
inveterate optimist like Talon might be surprised to see how his little settlement has flourished.

Perhaps two other general comments might be appropriate. First, industrialization of Quebec is a complex and in certain aspects a controversial subject that, in its economic ramifications, has hitherto been explored only little. By taking a historical-economic approach and by treating the subject in a systematic and particularly lucid manner, Faucher and Lamontagne's paper is in the truest tradition of the high quality of work which over the last decade or more has become so characteristic of the Social Sciences Faculty of Laval under the inspiring leadership of Father Lévesque.

Secondly, Lamontagne and Faucher appear to be keenly aware that an economic assessment of national or regional development requires the setting of certain rigorous criteria, the testing of hypotheses against reality, and the drawing together of salient conclusions into a framework of economic analysis which explains not only the inter-relationship of the forces at work but also the reasons for their existence. The authors have given us a more limited paper, and I think their decision has been a wise one. By giving us a progress report of some of their work and thinking, they make us look forward with keen interest to their next contribution. Also, by concentrating on a qualitative approach rather than by combining it with a quantitative assessment they are opening up a wide field for further research and study that could be particularly constructive and illuminating.

To turn now to the subject-matter of the paper, the authors have brought out very clearly the weaknesses and strengths of Quebec province as an industrial region. One of the principal weaknesses, which is fortunately losing importance, has been the distance from economical supplies of coal and iron and from markets. The principal strengths have been the large labour force and the abundant supplies of non-ferrous metals, timber and waterpower. Advances in technology and the fact that United States supplies of forest products and minerals have not kept pace with the growing demands of that market have brought into play a number of natural advantages of the region. As a result, the industrial development of Quebec has been much more rapid in [p. 40] the years since the beginning of this century than in the preceding period.

Thus Quebec has been carried on changing tides of fortune. It is interesting to recall an earlier period in the seventeen thirties under the " ancien régime » when Quebec even had an iron and steel industry - the St. Maurice Forges. Of course, we are told that the Forges operated at a loss and had to be financed out of the pockets of the King of France. But then we are also told by a contemporary that the manager and staff of the Forges were in very affluent circumstances, so perhaps this was simply an early example of the dangers of nationalized or subsidized industry. At any rate, in time the ample local supplies of bog-iron and charcoal passed and, with them, the Forges.

Today, the pendulum is swinging back again and Quebec is on the verge of becoming a major producer of iron ore, and I think one of the questions we will want to ask ourselves is whether this may become the basis of a steel industry. I am looking forward to an interesting discussion on this point 
because I know one of our authors has some pretty strong views on the subject ${ }^{1}$.

There is another important aspect of Quebec's industrial growth and that is its inter-relationship with and contribution to Canadian economic development. Lamontagne and Faucher emphasize that the new trend towards rapid industrial development became apparent in the Province of Quebec at the beginning of this century, and that progress was particularly marked after 1911. The authors make the point that the initial impetus for this development is to be found in the natural resources pattern of the province, which assumed new meaning after 1900 because it provided the raw materials and power needed to service the growing North American and overseas markets and to meet the requirements of technological advances which the Atlantic nations were achieving with remarkable persistence and speed. Looking at industrial development in its broadest sense, most of us will probably agree that these were two of the major factors.

These influences, however, were operative also in other regions of Canada even though they were affecting economic development of the various parts of the country to a different degree, at times [p. 41] one region pushing ahead of another, or one industry overtaking another. This competitive race between regions and industries was facilitated greatly by an economic climate encouraging free enterprise and individual initiative which resulted in many new discoveries, new wants and new production techniques. These endeavours were assisted by government economic policies which for the most part played a supplementary role to private endeavour.

The period that our authors describe as the time in which Quebec's industrial revolution occurred coincides with the period of most rapid economic expansion of Canada as a whole. To this national development Quebec has made a major contribution, but equally the industrial boom in this province has drawn a great deal of strength from the growth of the Canadian market and the ability of Quebec's industries to provide in both peace and war many of the strategic materials and manufactured products which this country and its principal trading partners required.

By 1900, Quebec's population of about 1.6 million comprised about 30 per cent of Canada's total and this proportion has changed little over the last fifty years. But economic development since the turn of the century was rapid not only in Quebec but particularly so in the western parts of the country. In fact, in relative terms, the growth of the Prairies and British Columbia was much more rapid than that experienced in the more settled regions of the central and Atlantic provinces. The reaction of the wheat economy in the Prairies and the mixed forestry, mineral, hydro power and fishing economy of British Columbia meant not only a great deal of wealth for these parts of Canada, but also increasing opportunities for established business in the eastern parts of the country.

Quebec: Rich Resources for Industry, by Maurice LAMONTAGNE, Public Affairs, Dalhousie University, Halifax, December 1948, pp. 256-262. 
While Quebec was about able to maintain its position, simply by growing as rapidly as the rest of the country, Ontario was not able to match this rate of expansion. The growth of the West has meant that Ontario, which had 41 per cent of Canada's population in 1900, now makes up only 33 per cent of the total, or just 4 per cent more than Quebec. Thus the shift to the West has been an historical force whose course has not been altered over the last fifty years even by the attractive economic opportunities that developped in Ontario, Canada's most industrialized province.

In response to the need to serve the Canadian and regional markets which are now $3 \frac{1}{2}$ times what they were population wise [p. 42] in 1900 and perhaps over 5 times in terms of real purchasing power, Quebec's industries expanded tremendously. Briefly, industrial establishments today have doubled in number, but what is more important, many of them are now vast arsenals using mass production methods and large amounts of intricate capital equipment against the small workshops of 1900 which used traditional production methods that had changed little over the centuries. The industrial labour force is now $3 \frac{1}{2}$ times what it was fifty years ago, and it produces an output 6 times greater in real terms. At the same time, workers in Quebec have been able to reduce hours worked per week from an average of about 61 hours to some 43 hours, or by close to 30 per cent.

Output per man-hour per industrial worker in manufacturing has risen on an average by 3 per cent per annum in Quebec over the last fifty years but, because of the decline in hours worked, the output per man-year has only risen by something like $1 \frac{1}{2}$ per cent. Comparable average increases for Canada as a whole are approximately $3 \frac{1 / 4}{4}$ per cent per man hour and 2 per cent per man year. The obvious question is : Why the difference ?

The first reaction might be that Quebec's industries are using less capital than industries in other regions. But interestingly enough, speaking in average terms, this is not the case. Land, buildings and machinery and equipment per employee in manufacturing (book value) is estimated at $\$ 6,500$ for Quebec in 1950 , or about $\$ 1,000$ higher than the Canadian average. The explanation for this, of course, is the prevalence of such high capital-using industries in the Province of Quebec as pulp and paper, chemicals, and hydro installation forming part of manufacturing operations.

Another explanation that one encounters frequently is that Quebec's industrial worker may be less efficient than workers in other parts of the country. It is difficult to generalize on this subject since usually those making this claim single out an individual operation to support their contention. But the fact remains that many of Quebec's native sons and daughters are now working in other parts of the country, or in the United States for that matter, and that, when language difficulties have stood in the way and have been overcome, their skill and performance will frequently match if not exceed that of their co-workers.

[p. 43]

Perhaps I can suggest two reasons for the slight difference in the long-term rate of output per man hour as between Quebec and other regions. One reason 
may be the industrial structure of this province, which in some respects is unique in Canada. It combines mass production industries of the first order requiring comparatively little manpower in relation to value of output, such as the large capital-using industries which I have just mentioned, with a number of other industries which require a large labour force in relation to the final value of commodities produced, e.g. textile, leather goods and tobacco industries. How concentrated these last mentioned industries are in the Province of Quebec is indicated by the fact that 87 per cent of workers employed in tobacco production were in Quebec, with the proportion for the boot and shoe industry being 59 per cent and for textiles and clothing about 57 per cent ${ }^{1}$.

Secondly, Quebec is the only province in Canada with more females than males. Availability of a large reserve of female workers has encouraged the growth of light manufacturing (and service) industries. Even though the tendency towards equalization of pay for men and women has been growing, some differential still exists and this will be reflected in the gross value of the final product.

There are other reasons for the differences in industrial productivity and some of these are implied in the preceding study. As to the somewhat wider difference in the rise in output per man year, there is, besides the varying rate of hourly productivity, some variation in the trend with respect to the number of hours worked per week. The average Quebec industrial worker works about 43 hours per week, as against the national average of $41 \frac{1}{2}$ hours ${ }^{2}$. But this gap has been closing steadily. I mentioned earlier that hours worked per week have declined in Quebec by close to 30 per cent since 1900. The national average decline was less, about 25 per cent, and it was still less in a number of other provinces.

There are interesting implications in the difference just reviewed regarding real earnings of industrial workers, their standard of [p. 44] living and the regional market their purchasing power supports. Perhaps the main impression I would like to leave is that I fully agree with the view of the authors of this essay that there are strong economic reasons why the Province of Quebec has such a diverse variety of, and in many respects such basically different industries, ranging all the way from a handicraft enterprise to the most up-todate and world-competitive mass production concern. Thus, a study of the process of industrialization in Quebec is really a study of contrasts. In fact, if we knew more about the economic impact of the changing structure of Quebec's industries we might find a number of explanations for things that are presently ascribed, for want of more specific knowledge, to « cultural » forces or to « traditional » sentiment.

In conclusion, I might raise three questions which the Faucher and Lamontagne paper brings to mind.

Based on employment figures of industries with 15 or more employees, as of June 1951.

See following chapter, Recent industrial growth. 
First, how serious a disadvantage has the distance from coal, iron and markets been and does it account as much for the failure of certain industries to locate in Quebec as the authors suggest? Or are there other factors such as insufficient local initiative and inadequate financial resources? And when high incomes in the more recent period made it possible to accumulate large savings in the region, have Quebec's peculiarly characteristic investment preferences reduced the availability of native capital for industrial development?

The second question relates to the influence of non-economic factors on the rate of industrial expansion, which the authors feel should not be overemphasized. With this I agree. But I wonder whether whatever influence such factors might have had would not also extend to establishing the pattern of Quebec's industries as it has developed over the last half century.

The third question refers to one aspect that has been covered only slightly in the paper: What has been the influence of government economic policies (federal, provincial and municipal) on Quebec's industrial expansion?

O.J. FIRESTONE 


\title{
CHAPTER II
}

\section{RECENT INDUSTRIAL GROWTH}

\author{
O.J. Firestone
}

\section{$\underline{\text { Retour à la table des matières }}$}

The foregoing analysis as well as many chapters or comments in this book refer to the striking industrial expansion of Quebec, particularly during and after World War II. This expansion involved the development of existing industries and the establishment of scores of others, many of which were connected with the national defence program, such as the aircraft industry. Both primary and secondary industries have shown unprecedented progress. Forest and mining production, reinforced by the use of electric power, still constitute the basis of the province's economy. The exploitation of the Ungava iron ore deposits, only in its early stage, is expected to reach an awe-inspiring magnitude. The Quebec part of the St. Lawrence is already referred to as a future Canadian Ruhr. Along with the primary industries, Quebec has also developed the processing and finishing of imported raw materials (cotton, iron, steel) and has increased an important export trade in timber, pulp and paper, aluminum and other non-ferrous metals ${ }^{1}$.

A complete and detailed story of this growth must await the availability of all the pertinent data. With a view to providing the reader with at least the main leading threads, the following pages present a certain number of tables which bring out the salient features of the economic structure of the province. The original information of which these tables are based was compiled by the Department of Trade and Commerce in Ottawa and has been obligingly communicated by Dr. O. J. Firestone. It covers the period 1939-1950 and, in most cases, compares the development of the province with that of Canada as a whole.

See Maurice LAMONTAGNE, Quebec: Rich Resources for Industry, Public Affairs, Vol. X1, No. 4, December 1948, pp. 256-262. 
[p. 46]

TABLE 1

RATE OF PROGRESS IN MANUFACTURING INDUSTRIES, QUEBEC, 1939-1950

Expansion in employment from 1939 to 1950 about equalled expansion in the preceding century :

1839: 30,000 persons employed

1939: 238,000 persons employed - increase of 208,000 over 1839

1950: 444,000 persons employed - increase of 206,000 over 1939

Other highlights of the growth from 1939 to 1950 :

\begin{tabular}{|c|c|c|c|}
\hline & Unit & 1950 & $\begin{array}{l}\text { Times figures } \\
\text { for } 1939 \\
\text { (approximate) }\end{array}$ \\
\hline Establishments & number & 12,000 & $1 \frac{1}{2}$ \\
\hline Employees & number & 444,000 & 2 \\
\hline Production (gross value) & $\$ 000,000$ & 4,300 & 4 \\
\hline $\begin{array}{l}\text { Production (gross value adjusted } \\
\text { for } \\
\text { price changes) }\end{array}$ & $\$ ’ 000,000$ & 2,000 & 2 \\
\hline Investment (capital expenditures) & $\$ ’ 000,000$ & 155 & 6 \\
\hline $\begin{array}{l}\text { Investment (capital expenditures } \\
\text { adjusted for price changes) }\end{array}$ & $\$ ’ 000,000$ & 73 & 3 \\
\hline Investment per employee & $\$$ & 349 & 3 \\
\hline $\begin{array}{l}\text { Investment per employee } \\
\text { (adjusted } \\
\text { for price changes) }\end{array}$ & $\$$ & 164 & $1 \frac{1}{2}$ \\
\hline
\end{tabular}


[p. 47]

TABLE 2

\section{EFFECTS OF PROGRESS IN MANUFACTURING INDUSTRIES, QUEBEC, 1939-1950}

I. Increase in leisure

1939: 48 hours, average working week for wage-earner

1950: 43 hours, average working week for wage-earner

II. Increase in earnings

1939: 37 , average hourly earning ; \$18, average weekly earning

1950: 93 , average hourly earning ; \$40, average weekly earning

In percentage money terms 1950 :

hourly earning is $151 \%$ above 1939

weekly earning is $125 \%$ above 1939

In percentage real terms 1950 :

hourly earning is 54\% above 1939

weekly earning is $38 \%$ above 1939

III. Increase in productivity

1950 : value of average hourly production of worker : $\$ 4.30$

1950 : value (in real terms) of average hourly production of worker : $14 \%$ above 1939

IV. Increase in income per capita : as a result of

1) rapid expansion in manufacturing industries

2) similar expansion in secondary industries

3) buoyant domestic and foreign markets

1950 : personal income per capita is $\$ 843$

1950 : personal income per capita is $154 \%$ above 1939

1950 : personal income per capita in real terms is $55 \%$ above 1939 
[p. 48]

TABLE 3

COMPARATIVE DISTRIBUTION OF EMPLOYMENT IN QUEBEC, 1939-1950

\begin{tabular}{|c|c|c|}
\hline \multicolumn{2}{|c|}{$\begin{array}{c}\text { Out of every } 10 \text { persons } \\
\text { looking for work } \\
\text { in }\end{array}$} & \\
\hline 1939 & 1950 & \\
\hline $1 \frac{1}{2}$ & Almost no one & ...Could not find any work \\
\hline $2 \frac{1}{2}$ & 2 & ...Were able to find work on farms \\
\hline 6 & 8 & ...Found jobs in cities, towns and villages \\
\hline \multicolumn{3}{|l|}{ Of these : } \\
\hline 2 & 2 & $\begin{array}{l}\text {..Were employed in commercial, finance and } \\
\text { service occupations }\end{array}$ \\
\hline 1 & 1 & $\begin{array}{l}\text {... Was active in community service or was } \\
\text { holding a government job }\end{array}$ \\
\hline \multicolumn{3}{|c|}{ The remaining : } \\
\hline 3 & 5 & ...Were employed in industry \\
\hline \multicolumn{3}{|l|}{ Of whom : } \\
\hline 1 & 1 & $\begin{array}{l}\text {..Was working in primary industries, viz. } \\
\text { mining, wood operations, etc. }\end{array}$ \\
\hline 2 & 4 & $\begin{array}{l}\ldots \text { Were active in manufacturing, electric power } \\
\text { and other utility undertakings }\end{array}$ \\
\hline
\end{tabular}


[p. 49]

TABLE 4

RATE OF INDUSTRIAL CHANGE, CANADA AND QUEBEC, 1939-1950

(in percentage)

\begin{tabular}{|c|c|c|}
\hline & \multicolumn{2}{|c|}{$\begin{array}{l}\text { Change from } 1939 \text { to } \\
\qquad 1950^{\mathrm{a}}\end{array}$} \\
\hline & Quebec & Canada \\
\hline Employment in manufacturing industries & +87 & +85 \\
\hline Employment in utilities & +80 & +64 \\
\hline Employment in primary industries (agriculture excluded) & +20 & +31 \\
\hline Employment in agriculture & -18 & -22 \\
\hline Total civilian employment & +27 & +24 \\
\hline Value of output of manufacturing industries & +312 & +302 \\
\hline Volume of output of manufacturing industries & +92 & +88 \\
\hline New investment in manufacturing, in value terms & +474 & +430 \\
\hline New investment in manufacturing, in volume terms & +181 & +154 \\
\hline Electric energy produced (1950: 27.5 bill. kWh.) & +80 & +79 \\
\hline Electric energy consumed & +82 & +85 \\
\hline Per capita production of electric power produced (1950: 7,069 kWh.) & +50 & +50 \\
\hline Per capita electric energy consumed (1950 : 5,564 kWh.) & +51 & +54 \\
\hline Hours worked in manufacturing industries per week(1950 : 43.3) & -10 & -11 \\
\hline Wage rates in manufacturing industries per hour in real terms & +54 & +49 \\
\hline Weekly earnings in manufacturing industries in real terms & +38 & +32 \\
\hline Personal income per capita in real terms & +55 & +54 \\
\hline
\end{tabular}

${ }^{\mathrm{a}}+$ indicates increase $;$ - indicates decrease. 
[p. 50]

TABLE 5 VALUE AND PER CENT INCREASE IN VALUE OF OUTPUT
OVER 1939, MANUFACTURING INDUSTRIAL GROUPS,
QUEBEC AND CANADA, 1950

\begin{tabular}{|c|c|c|c|c|}
\hline \multirow{3}{*}{ INDUSTRIES } & \multicolumn{2}{|c|}{$\begin{array}{c}\text { Value of output } \\
1950\end{array}$} & \multicolumn{2}{|c|}{$\begin{array}{c}\text { Per cent increase } \\
1939-1950\end{array}$} \\
\hline & Quebec & Canada & Quebec & Canada \\
\hline & $\$ \$^{\prime} 000,000$ & $\$ \$^{\prime} 000,000$ & $\%$ & $\%$ \\
\hline Food and beverage & 745 & 3,067 & 271 & 250 \\
\hline Tobacco & 125 & 181 & 205 & 159 \\
\hline Leather & 86 & 188 & 153 & 132 \\
\hline Primary textile & 400 & 718 & 312 & 292 \\
\hline Clothing & 405 & 693 & 237 & 201 \\
\hline Wood products & 241 & 1,010 & 502 & 437 \\
\hline Pulp and paper & 534 & 1,179 & 338 & 337 \\
\hline Printing and publishing & 90 & 355 & 221 & 196 \\
\hline Iron and steel & 323 & 1,513 & 382 & 371 \\
\hline Transportation equipment & 263 & 1,223 & 673 & 418 \\
\hline Non-ferrous metal products & 366 & 1,084 & 259 & 231 \\
\hline Electrical apparatus and supplies & 164 & 694 & 720 & 680 \\
\hline Rubber & 73 & 375 & 421 & 436 \\
\hline Non-metallic minerals & 82 & 277 & 332 & 333 \\
\hline Petroleum and coal & 177 & 614 & 312 & 326 \\
\hline Chemical products & 189 & 631 & 263 & 285 \\
\hline Miscellaneous & 43 & 177 & 258 & 321 \\
\hline
\end{tabular}


[p. 51]

TABLE 6

VOLUME AND PER CENT OF CANADIAN PRODUCTION,
BASIC COMMODITIES AND SERVICES, QUEBEC, 1950

\begin{tabular}{|c|c|c|c|}
\hline PRODUCTS & Unit & Total output & $\begin{array}{l}\text { Per cent of } \\
\text { Canadian } \\
\text { production }\end{array}$ \\
\hline & & & $\%$ \\
\hline \multicolumn{4}{|c|}{$\begin{array}{l}\text { Of which Quebec was the sole } \\
\text { producer: }\end{array}$} \\
\hline Aluminum Ingots & ton & 394,756 & 100 \\
\hline Titanium Ore & ton & 100,500 & 100 \\
\hline Molybdenite & pound & 103,508 & 100 \\
\hline Iron Oxide & ton & 11,522 & 100 \\
\hline \multicolumn{4}{|c|}{$\begin{array}{l}\text { Of which Quebec was the leading } \\
\text { producer: }\end{array}$} \\
\hline Newsprint & ton & $2,750,000$ & 57 \\
\hline Asbestos & ton & 866,950 & 99 \\
\hline Sulphur & ton & 144,778 & 49 \\
\hline Feldspar & ton & 26,921 & 84 \\
\hline Mica & ton & 1,053 & 61 \\
\hline Tellurium & pound & 32,000 & 65 \\
\hline Selenium & pound & 173,000 & 49 \\
\hline Cement & barrel & $6,926,468$ & 41 \\
\hline Electrical energy & M. kWh. & $27,475,570$ & 54 \\
\hline \multicolumn{4}{|c|}{$\begin{array}{l}\text { For which Quebec was the second } \\
\text { largest } \\
\text { producer in Canada }{ }^{a} \text { : }\end{array}$} \\
\hline Sawn lumber & M. bd. ft. & $1,043,000$ & 16 \\
\hline Gold & ounce & $1,097,593$ & 25 \\
\hline Silver & ounce & $4,388,173$ & 20 \\
\hline Copper & ton & 72,826 & 28 \\
\hline Lead & ton & 7,616 & 5 \\
\hline Zinc & ton & 85,121 & 30 \\
\hline Lime & ton & 391,887 & 34 \\
\hline Sand and gravel & ton & $20,564,308$ & 31 \\
\hline
\end{tabular}

${ }^{a}$ Exceeded either by Ontario or British Columbia. 
[p. 52] TABLE 7

VOLUME AND PER CENT OF CANADIAN PRODUCTION, LEADING MANUFACTURED ARTICLES, QUEBEC, 1949

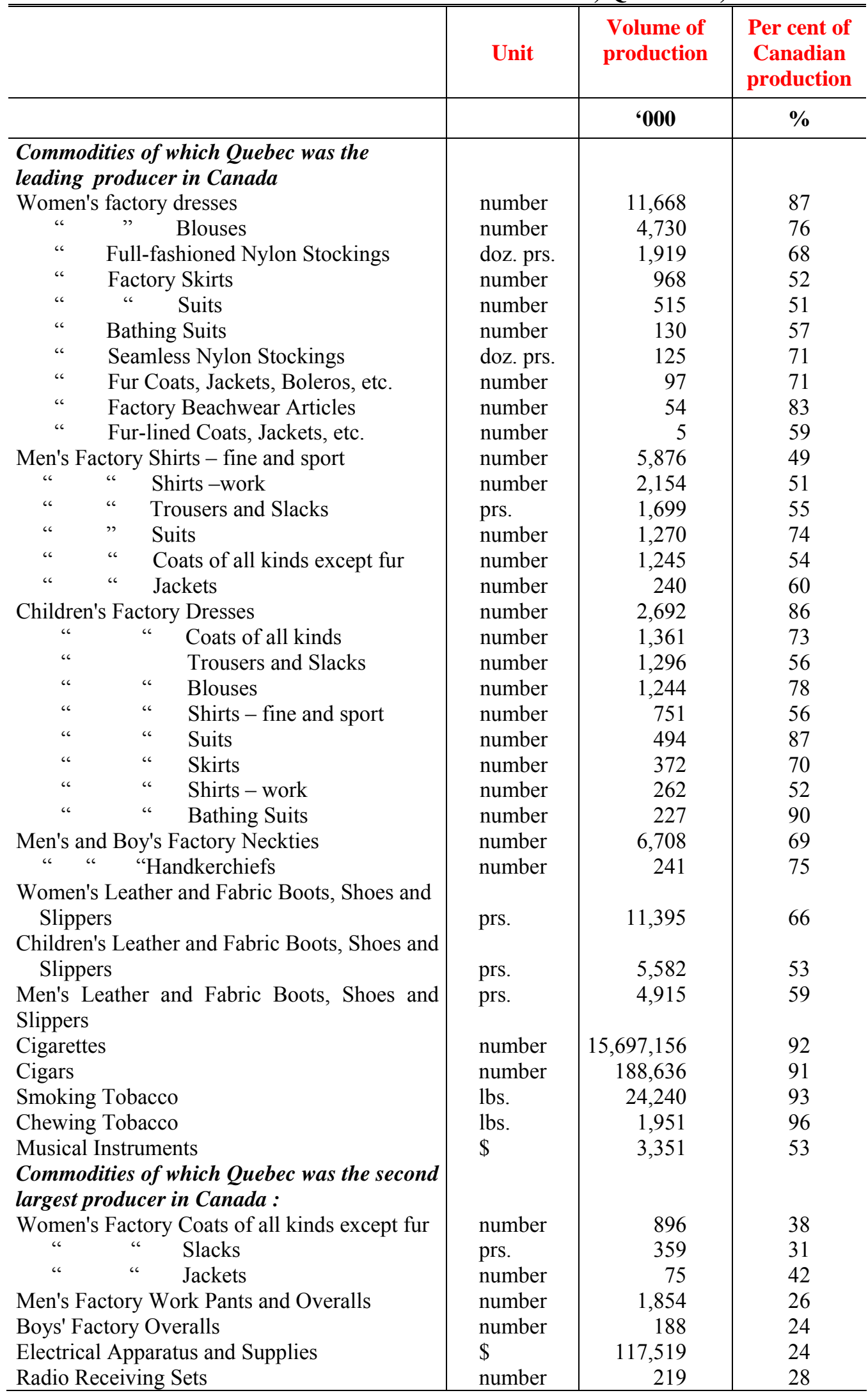


[p. 53]

TABLE 8

NEW MANUFACTURING FIRMS ESTABLISHED
${ }^{a}$
IN QUEBEC AND CANADA, 1946-1950

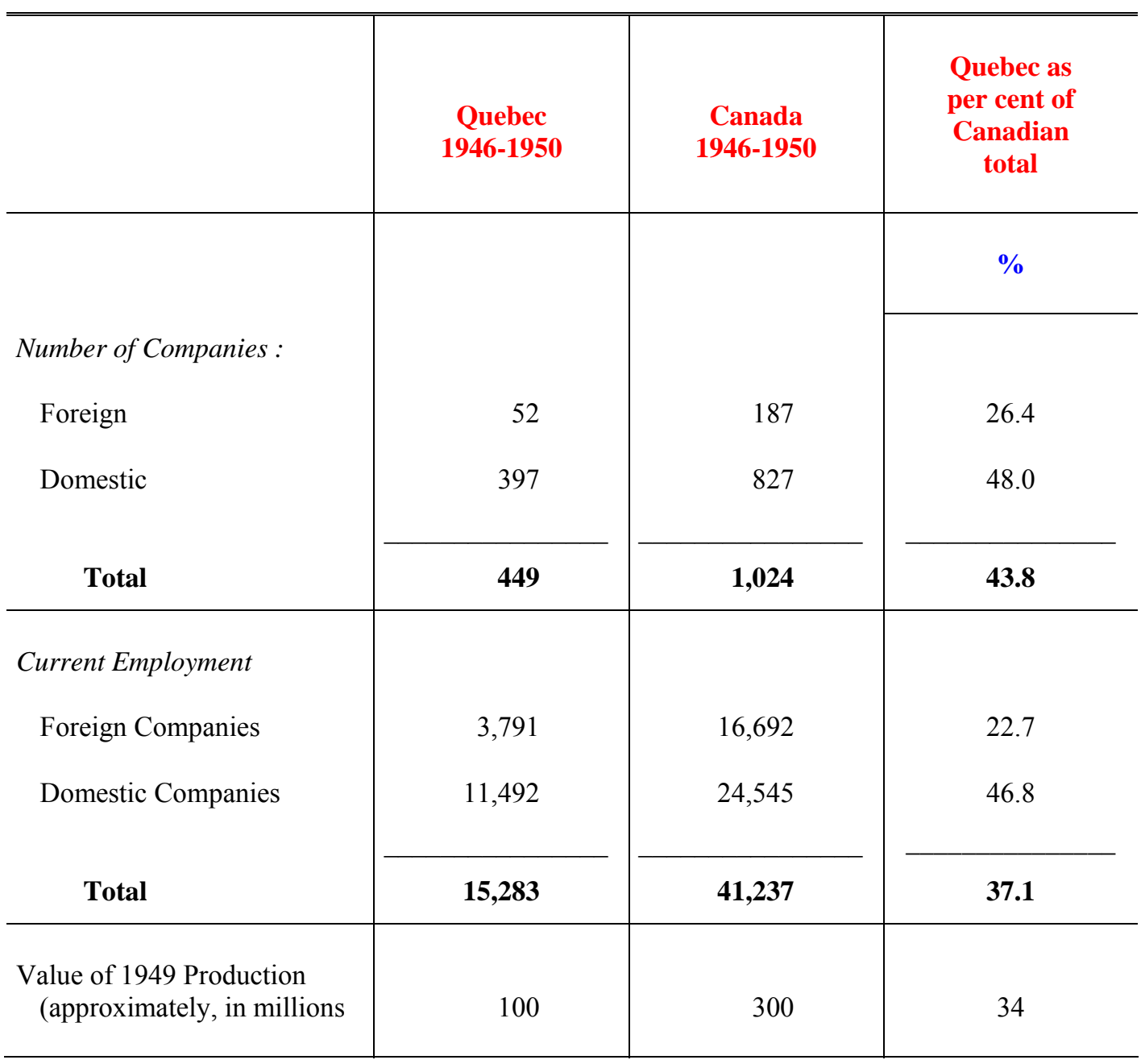

${ }^{a}$ Employing 10 persons or more. 
[p. 54]

TABLE 9

INDEX OF INDUSTRIAL EXPANSION IN CANADA, BY PROVINCES, $1952(1946=100.0)$

\begin{tabular}{|c|c|c|c|c|c|c|c|c|}
\hline \multirow[b]{2}{*}{ PROVINCES } & \multirow{2}{*}{$\begin{array}{l}\text { Popu- } \\
\text { lation }\end{array}$} & \multirow{2}{*}{$\begin{array}{c}\text { Civilian } \\
\text { employ- } \\
\text { ment }\end{array}$} & \multicolumn{4}{|c|}{ MANUFACTURING } & \multirow{2}{*}{$\begin{array}{c}\text { Value of } \\
\text { mineral } \\
\text { production }\end{array}$} & \multirow{2}{*}{$\begin{array}{l}\text { Installed } \\
\text { Hydro- } \\
\text { Electric } \\
\text { capacity }\end{array}$} \\
\hline & & & $\begin{array}{c}\text { Number } \\
\text { of } \\
\text { establish- } \\
\text { ments }\end{array}$ & $\begin{array}{c}\text { Number } \\
\text { of } \\
\text { employees }\end{array}$ & $\begin{array}{c}\text { Gross } \\
\text { value of } \\
\text { production }\end{array}$ & $\begin{array}{l}\text { Invest- } \\
\text { ments }\end{array}$ & & \\
\hline Newfoundland & 114.0 & $106.1^{b}$ & - & - & 303.3 & $108.0^{b}$ & 300.0 & $111.4^{b}$ \\
\hline Prince Edward Island & 109.6 & 86.4 & - & - & 218.2 & 150.0 & - & 88.5 \\
\hline Nova Scotia & 106.7 & 105.6 & 121.4 & 110.0 & 180.4 & 135.4 & 182.9 & 121.8 \\
\hline New Brunswick & 109.6 & 92.0 & 120.0 & 113.0 & 195.3 & 153.4 & 220.0 & 100.0 \\
\hline Quebec & 115.0 & 113.5 & 113.0 & 119.9 & 209.7 & 105.1 & 295.7 & 122.4 \\
\hline Ontario & 116.2 & 115.3 & 115.8 & 124.1 & 229.7 & 200.3 & 250.0 & 142.1 \\
\hline Manitoba & 109.8 & 92.1 & 114.3 & 113.2 & 174.7 & 116,7 & 187.5 & 146.8 \\
\hline Saskatchewan & 101.2 & 88.2 & - & 91.7 & 164,7 & 228.9 & 233.3 & 123.1 \\
\hline Alberta & 120.8 & 105.3 & 146.2 & 126.1 & 198.4 & 723.4 & 316.7 & 223.7 \\
\hline British Columbia & 119.4 & 113.6 & 155.6 & 128.0 & 222.2 & 177.0 & 266.2 & 166.7 \\
\hline Canada & 117.3 & 111.1 & 122.1 & 122.9 & 218.7 & 175.9 & 267.8 & 137.9 \\
\hline
\end{tabular}

Compiled by Maurice Lamontagne, from Progress and Impact of Canadian Industrial Development, by Provinces, 1939-1952, Department of Trade and Commerce, Ottawa, 1952.

${ }^{a} 1947=100.0$

${ }^{b} 1950=100.0$ 


\title{
CHAPTER III
}

\section{THE STATE OF AGRICULTURE}

\author{
Charles LEMELIN
}

$\underline{\text { Retour à la table des matières }}$

This essay was originally expected to answer the question : "What has been the effect of industrialization on agriculture in Quebec?» Such a question is equivocal. First, it implies that the degree of our industrialization has been such as to affect agriculture. Second, it assumes that the sequence of causality has been in one direction only. The main objective of the following pages will be to examine these two assumptions.

It is of primary importance to determine carefully the actual degree of industrialization, for certain fundamental changes, in agriculture depend on important prerequisites that can not be realized unless the degree of industrialization is relatively high. The second problem, the direction of causality between industry and agriculture, is harder to determine. In general, it can be considered from two different angles. On the one hand, one can assume that, in a given milieu, say the province of Quebec, there has been enough industrialization to bring about agricultural changes but that these were hampered or prevented by factors of a cultural nature - tradition, institutions, religious values, etc. On the other hand, one can assume that cultural factors alone can not, beyond a certain point, prevent the impact of industrialization in farming areas ; consequently, if an agricultural system does not change appreciably over a long period of time, it is because of insufficient industrialization in the adjacent areas. The best approach must probably combine the two views, but for reasons that will presently be shown, the second approach seems to be better suited to a relevant analysis of the Quebec situation.

The study of Lamontagne and Faucher shows that industrialism in the full sense of the term is a recent phenomenon in Quebec and that until recently it has been limited to specific geographical areas. Many of the important 
developments took place in [p. 56] frontier areas where agricultural land supply was inadequate, as in the St. Maurice valley, or where climatic conditions set a limit to orderly farming production for the market, as in the Abitibi and even in the Lake St. John districts ${ }^{1}$. History then strongly supports the hypothesis that the relatively slow progress of agriculture in Quebec is largely due to the belatedness of industrialization. It is the purpose of this paper to analyse the relationships between industry and our agriculture in the light of this hypothesis. The historical account of agricultural development in Quebec is well enough known, thanks particularly to such valuable studies as those of Raoul Blanchard, Marsh and Haythorne, F. Létourneau, L. de G. Fortin, and Esdras Minville ${ }^{2}$. All these studies stress two essential features of our agricultural system : the lack of efficiency, the low standard of living.

\section{EFFICIENCY OF QUEBEC'S AGRICULTURE}

The net income per farm in Quebec in 1941 was only 87 per cent of the $\$ 880$ average for the whole country. In 1951, Quebec's farm income averaged about $\$ 1,890$ as compared to $\$ 2,350$ for the whole country, so that the net income per farm for Quebec stood then at 80 per cent of the national average $^{3}$. The productivity per worker in Quebec and Canada can be compared in the same manner by adding the wage-bill to the aggregate net income, and relating this sum to the total labour force in agriculture (including farm operators, family unpaid labour, year-round hired labour, and an estimate in man-years of seasonal labour). In [p. 57] 1941, the productivity so measured was $\$ 438$ in Quebec or 79 per cent of the Canadian average ${ }^{4}$.

The cash income per farm in Quebec went up from $\$ 460$ in 1931 to $\$ 925$ in 1941. If allowance is made for the change in the definition of a « farm », the figures for 1941 and 1951 are $\$ 987$ and $\$ 3,220$. These values represent a constant ratio of 75 per cent of the corresponding averages for Canada ${ }^{5}$. Even

F.-K. CORMINBOEUF, Les ressources agraires de la province de Québec : Disponibilité présente et future, L'Actualité Économique, août-septembre 1944, vol. 1, n 4, pp. 353371 ; A. GOSSELIN and G P. BOUCHER, Settlement problems in North Western Quebec and North Eastern Ontario, Canada, Department of Agriculture, Pub. 758, 1944, p. 9.

2 See, particularly: Raoul BLANCHARD, L'Est du Canada français, 2 vol., Montréal, 1935 ; Louis de Gonzague FORTIN, L'Action agronomique avant 1912, Agriculture, Automne 1949 ; Geo. U. HAYTHORNE and L. G. MARSH, Land and Labour : A social survey of agriculture and the farm labour market in Central Canada, Oxford University Press, 1941 J. LÉTOURNEAU, Histoire de l'agriculture, Canada français, Montréal 1950 Esdras MINVILLE, éd. L'Agriculture, Montréal, 1943.

Computed from Frank SHIFFRIN, Farm Income : Cash and Net, 1926 to 1948, Canada, Department of Agriculture, 1949; The Quarterly Bulletin of Agricultural Statistics, Census of Agriculture 1941-1951.

4 Wage bill obtained from Census of Agriculture 1941 ; labour force computed from Census of Agriculture 1941 ; for method of estimating, seasonal labour : Geo. HAYTHORNE and L. C. MARSH, Land and Labour, p. 554.

Computed from : Frank SHEFRIN, op. cit. 
if allowance is made for a difference in the price structure, the discrepancies are great enough to show that real output per farm and per worker is relatively low. Quebec's agriculture is unquestionably characterized by a lack of efficiency. Assuming a simple relation between the standard of living of farm families and the efficiency of the farm enterprise, it follows that the standard of living on the average farm is bound to be lower in Quebec if compared to the country as a whole.

The unavoidable question, then, is : «Is this lack of efficiency due to economic or social factors? Is it due to an insufficient degree of industrialization or to a lack of response to industrialization ? » To avoid hasty conclusions, let us review the factors that may account for any changes in the output per farm, per worker and per capita. The most important of these are :

a) The demand for agricultural products ;

b) The intensity of use of factors of production in combination with available labour ;

c) The volume of farm population in relation to the type of farming and the size of the labour force.

a) The demand for agricultural products, particularly for food, is related to the consumers' income. Colin Clark reports a study of Allen and Bowley ${ }^{1}$ showing that the income elasticity for food for a sample of family budgets in different countries ranges from 0.3 to 0.9 . In Canada, while the personal income per capita changed from $\$ 427$ in 1930 to about $\$ 960$ in 1950 , the aggregate personal expenditures on consumers' goods changed from $\$ 4,204,000,000$ [p. 58] to $\$ 11,862,000,000$ during the same period. The proportion of this aggregate spent on food remained stable at about 25 per cent for each year during the two decades ${ }^{2}$. If the series is deflated by the cost of living indices ${ }^{3}$, the ratio decreases from 25 to 16 per cent during the period. Therefore, with increasing income per capita, the absolute amount of food demanded has increased in Canada at a lower rate than income, but the relative price of agricultural products has improved greatly, so that there is more incentive for the farmer to increase his production for the market.

In Quebec, income per capita between 1926 and 1950 was at all times smaller than the Canadian average during that period. It stood at 85.3 per cent of the national average in 1926, at 93 per cent in 1930, and at slightly over 80 per cent in the war and postwar years ${ }^{4}$. If the set of relations discussed above holds for Quebec, the relatively lower income per capita means a relatively

Colin CLARK, The conditions of Economic Progress, London, 1951, p. 368.

Computed from : National Accounts Income and Expenditure 1926-50, Canada, Dominion Bureau of Statistics, 1952, and Estimates of population available in Canada Year-Books.

Published in Canadian Statistical Review, Canada, Dominion Bureau of Statistics.

National Accounts Income and Expenditure 1926-1950, Canada, Dominion Bureau of Statistics, 1952 ; Estimates of population in Canada Year-Books and Census Reports. 
smaller incentive for the farmers to shift from subsistence farming to farming for the domestic market ${ }^{1}$.

b) The factors of production, land, labour, and technology, form the second set of variables affecting farm output and efficiency. In order to obtain a bird's-eye view of the way in which these factors of production are combined in Quebec, a comparison can be made between the relative importance of the number of farms to the Canadian total and the relative importance of typical factors on the basis of the 1941 census data.

The number of farms represented 21 per cent of the Canadian total, the farm population, over 25 per cent. While active population, full-time hired workers and family workers represented slightly below 25 per cent of the corresponding Canadian totals, the relative importance of the total labour force, including estimates of seasonal labour in man-years, was smaller at 22.4 per cent. [p. 59] What is more significant, the number of acres in farm land and the number of acres in improved farm land represented only 11.0 and 9.6 per cent respectively. There was as little as 18.1 per cent of the total number of purebred cattle and $3.7^{2}$ per cent of the total number of tractors. Another evidence of the extensive type of agriculture prevailing in Quebec was the high ratio (31.8 per cent for each census category) of «subsistence » and "part-time » farms to the total for the country. In the category "mixed farming », Quebec's share was 26 per cent.

That these characteristics have not changed substantially with the war is made clear by more recent information on specific points. The census of 1951 reveals that the proportion of Quebec farms to the Canadian total is still about 21 per cent. The proportion of acres to the total for all Canadian farms is slightly lower than it was 10 years ago. In 1950, Quebec purchased 22.1 per cent ${ }^{3}$ of the total quantity of mixed fertilizers sold on the Canadian market. In 1949, the purchase of farm machinery in Quebec represented as little as 7.7 per cent ${ }^{4}$ of the total purchases ${ }^{5}$. It is safe to conclude that, on the average and until very recently, the agricultural resources were not used very intensively. This conclusion holds a fortiori for previous decades so that the present features may be considered as reflecting a fundamental tendency. An inadequate combination of production, as well as and perhaps more than the condition of demand accounts for the low productivity of Quebec farms.

c) The figures just mentioned make it clear that the farm population is kept at a maximum in terms of other resources. This, along with the limited supply of arable land ${ }^{6}$, explains the small size of farms even in areas of extensive

I assume that what is true for domestic demand holds a fortiori for export markets.

This comparison does not imply that with 21 per cent of the Canadian farms, Quebec should have 21 per cent of all tractors.

Quarterly Bulletin of Agricultural Statistics, Canada, Department of Agriculture, Jan.March 1952, p. 86.

Farm implement and equipment sales, 1949, Canada, Dominion Bureau of Statistics, p. 5. Since this essay was written, census data on farm machinery for 1951 have been published. With 21.6 per cent of all Canadian farms, the Province of Quebec had 8 per cent of all farm tractors. See Census of Agriculture 1951, Bulletin 6 - 3.

6 F. H. CORMINBCEUF, op. cit., p. 353-371. 
cultivation, i.e. in areas [p. 60] which would require a larger number of acres per farm to provide a fair living for the family ${ }^{1}$."

The rural population of Quebec increased very slowly from 919,000 in 1871 to $1,038,000$ in 1911 , and from $1,037,000$ in 1921 to $1,222,000$ in 1941 , but its relative importance decreased rapidly: 60.3 per cent of the total population in 1901 and only 36.7 per cent in 1941. There is evidence, however, that farm population has been very stable over time. Hughes isolated a «block of 46 counties in the heart of Quebec» for which the rural population was 705,578 in 1871 and 705,240 in 1931. "Enclosed in this block », writes Hughes, «but not counted because they had a higher increase of rural population are Sherbrooke, Drummond, Chambly, and Champlain. Examination proves that the apparent rural increase in these counties is really a growth of urban centers ». And he adds : «When there is a downward trend, it has not been accompanied by a decline of agricultural production or of the number of people engaged in it $^{2}$. »

Haythorne estimates that the total labour force on farms increased only from 204,000 in 1891 to 226,000 in 1931 . The family workers numbered 71,500 in $1891,69,700$ is 1921 , and 87,900 in $1931^{3}$. Consequently, efficiency or, more specifically, the quantitative ratio describing the output per capita, is not likely to improve through a decrease in farm population and in farm labour which goes with it, except if demand for labour in industries increases rapidly and if the geographical mobility of workers is sufficiently high.

Urbanization has also affected farm population both from within and from without. Enid Charles has shown that natural fertility was declining for two successive generations of women at the census of 1941. Although the level of fertility in absolute terms was comparatively high for the rural women of Quebec, the rate of decrease from one generation to the next was the great-[p. 61] est in terms of any classification. Enid Charles attributes this change to the « spread of urban ways of living ${ }^{4}$ ». Urbanization also provided a labour market which could at least absorb the surplus population of the rural areas, although the opportunities were mainly in cheap labour industries, and the demand was for unskilled trades ${ }^{5}$. Notwithstanding the constant emigration

J. D. BLACK, Note Extensive vs. the Intensive margin, Journal of Farm Economics, vol. XI, 1929 David L. MACFARLANE, Technology and Agriculture, Queen's Quarterly, vol. LVII, 1, 1950, pp. 54-68, especially pp. 54, 58.

2 Everett C. HUGHES, Industry and the rural system in Quebec, Canadian Journal of Economics and Political Science, vol. IV, 1938, pp. 342-349.

3 Geo. N. HAYTHORNE and L. C. MARSHALL, op. cit., p. 545. MacFarlane estimates that the male farm labour force passed from 214,000 in June 1931 to 233,000 in June 1951 : Mobility in the Canadian Agricultural Labour Force, Unpublished manuscript, p. 5. For two generations of rural women, the fertility had decreased by 63.2 per cent in Quebec as against a decrease of 56.6 per cent only for the whole country. For the urban groups, the decrease is around 55 per cent in Canada and from 55 to 60 in Quebec, depending on the size of the locality. See, Trends in Canadian family size, Canada, Dominion Bureau of Statistics, Bulletin F-1, 1944, p. 50, p. 72.

See chapter IV, Population problem, by Nathan KEYFITZ; Everett-C. HUGHES, Industry and the rural system in Quebec, Canadian Journal of Economics and Political 
from the country and the consequent stability of the total volume of farm population in Quebec, this agricultural labour force is paradoxically still too high, at least in terms of high farming productivity. It would have required a further reduction of the farm population to stimulate technical improvement and more intense production.

To sum up, three main sets of factors are associated with the low productivity of our agriculture : a low level of consumers' demand, extensive and subsistence farming, a relatively high volume of farm population.

\section{EFFICIENCY BY REGIONS AND BY TYPES OF FARMING}

Although our industrial progress was limited to particular areas, it had, indeed, some indirect beneficial effects on our total economy. The price mechanism was not completely inoperative and there was certainly some « multiplier» effect which contributed to an increase in income in every sector of our economic life, including agriculture. There were also some mobility and some tendencies towards equalization of factor prices between sectors, but this indirect impact of industrialization was limited. This is made clear by a consideration of regional differences in agricultural production.

[p. 62]

J. E. Lattimer ${ }^{1}$ published in 1946 a regional analysis which permits to visualize the association between the purchasing power of consumers (measured in terms of yearly earnings per wage-earner in 1940) and the economic status of farms on a regional basis. The setting of this analysis consists in arranging all the counties in four groups by decreasing average earnings per capita. The average earning per wage-earner was over $\$ 1,000$ in four counties only: Montreal and Jesus Islands, Chambly, Abitibi and Temiskaming. It ranged from $\$ 800$ to $\$ 1,000$ in 13 counties, from $\$ 600$ to $\$ 800$ in 25 counties, and was below $\$ 600$ in 24 counties. Except for group I with the highest average earning, there was a positive relationship between the purchasing power and either the net return per farm or the net return per farm worker. In general, in regions where the purchasing power was the highest the resources were used more intensively, as evidenced by the positive relationship between the average earnings per wage-earner and the percentage of farms reporting tractors or the yield per cow. Another indication of the

Science, vol. IV, 1938, pp. 341-349 ; Everett-C. HUGHES, Position and Status in a Quebec industrial town, American Sociological Review, vol. III, Oct. 1938 ; Raoul BLANCHARD, Les excédents de population et l'agriculture dans la province de Qu4bec, L'Actualité Économique, janv.-mars, 1949. There is also migration from well-to-do farm families into liberal professions.

J. E. LATTIMER, Shifting markets for farm products, Macdonald College, Bulletin No. 18, Quebec, 1946. 
association between purchasing power and the intensity of cultivation was the increasing size of farms with decreasing average earnings per wage-earner.

This regional study indicates a general association between the purchasing power of the community and the economic performance on farms. However, there may be some other limitational factors preventing the purchasing power to affect the farm. Suffice it to point out that in Abitibi and Temiskaming districts, a survey made in 1947 attributes the difficulties of farmers to two causes : the climatic conditions, especially the seasonal character of certain agricultural productions, and, secondly, the institutional arrangement in communications favouring exchanges of agricultural products with Ontario and the Prairies ${ }^{1}$. The latter condition, it may be added, depends in turn on the particular technological relationship of the industrial sector of this area with Ontario and this relationship itself is a direct result of past economic development. Lattimer's study shows clearly that adequate demand and a high purchasing power, though [p. 63] not a sufficient condition, are nevertheless prerequisites to economic progress on farms. If industrial development had been more diffused, the prosperity of agriculture would have been more general, other conditions permitting.

In the first section of this paper, the characteristics of Quebec farms were expressed in terms of a single average describing the sector globally. G. L. Burton ${ }^{2}$ has analyzed the relation between types of farming and productivity in terms of gross sales per farm. In 1940, 31.8 per cent of the total number of subsistence farms in Canada were in the province of Quebec. Of the total number of full-time farms within the province, 44 per cent were subsistence farms. The corresponding ratio for Canada was 28 per cent only. While this 28 per cent of Canadian subsistence farms sold only 8 per cent of the total gross sales of full-time farms, in Quebec the 44 per cent of subsistence farms sold as much as 22 per cent of the provincial gross sales. In both cases, i.e. for Canada and Quebec, subsistence farms were much less productive than nonsubsistence farms. For the entire country, the average gross sales per farm for each group was $\$ 285$ and $\$ 1,229$ respectively. But while the average of gross sales per non-subsistence farm for Quebec was 26 per cent lower than the Canadian average and 31 per cent lower than the Ontario average, the average for subsistence farms was at about the same level at $\$ 328$ in both provinces, or 15 per cent higher than in Canada. This would mean that there is room in Quebec for some improvement in efficiency, even on non-subsistence farms. In other words, the lack of efficiency in Quebec cannot be attributed only to the high proportion of subsistence farming, unless it is assumed that a great deal of the handicaps facing the non-subsistence farms are precisely due to competition by subsistence farms.

E. P. REID and H. DUBORD, The market for farm products in North Western Quebec, Ottawa, Department of Agriculture, 1947, pp. $36 \mathrm{ff}$.

G. L. BURTON, Do Canadian farmers produce a fair share of the national income ?, Agricultural Institute Review, May 1948, pp. 205-207. 


\section{THE STANDARD OF LIVING}

So far, evidence has established that our general economic development did not affect agriculture appreciably. This agriculture is characterized by persistence over time of subsistence farming. Non-subsistence farms display a low productivity. The [p. 64] farm enterprise, therefore, does not in general provide a sufficient return to allow for a normal level of living and the latter is attained only because farm income is supplemented by off-farm work, subsidies and transfer payments.

For this reason, a systematic analysis of the standard of living on family farms would have been more directly relevant to the problem under discussion. But statistics published on subsidies, transfer payments, and other pertinent information do not lend themselves to an analysis of farm or rural households, and the case studies available are insufficient to warrant any generalization concerning this standard. I simply intend to draw attention to a few indications concerning household preferences and attitudes that are reported in Miner's recent survey of St. Denis ${ }^{1}$ and in two other studies. One of these was published in 1944 following a survey made in 1937-38 by Gosselin and Boucher ${ }^{2}$ in the colonization district of north-western Quebec. The other is a sample study by McNaughton, Mann and Blackwood ${ }^{3}$ of 85 farm families in the county of Nicolet.

From these studies it seems that, granting a minimum level of income, there is a marked preference for transportation and communication equipment. At St. Denis, the number of telephones increased from 2 to 40 between 1937 and 1949. During the same period, the number of automobiles, trucks or tractors (which, says Miner, were used to go to town) raised from 7 to 37. In Nicolet, " ninety-four per cent of the families had a radio in their homes and they considered that this was an important source of information and entertainment. » The average family budget in Nicolet was low $(\$ 1,500)$, yet « 14 per cent owned an automobile; 8 per cent owned a truck and 1 per cent owned both an automobile and a truck. »In the northwest settlement, the average budget (only $\$ 292$ in new colonies and $\$ 343$ in old colonies) was insufficient to permit such luxuries. However, 11 out of a sample of 54 [p. 65] settlers had automobiles which, incidentally, averaged only $\$ 375$ in value.

Horace MINER, A new epoch in rural Quebec, American Journal of Sociology, vol. LVI, No. 1, July 1950 .

A. GOSSELIN and G. P. BOUCHER Settlement problems in north-western Quebec and north-eastern Ontario, Canada, Department of Agriculture, Pub. 758, 1944.

3 M. A. McNAUGHTON, J. M. MANN and H. B. BLACKWOOD, Farm family living in Nicolet County, Quebec, 1947-48, Canada, Department of Agriculture, 1950. 
Another point of interest is whether farmers will spend more of an increment of income on farm equipment than on household equipment. Since the household income includes an important proportion of family allowances and since the market for farm products is considered unstable, as Miner observed, it is to be expected that purchases of equipment will be for commodities that directly increase the well-being of the household rather than for those that would primarily contribute to increasing the productivity of the enterprise. In this respect Miner makes the following comment: "One compelling reason for farm families to depart from the old technology is clear. There has been a growing resistance ... to the assuming of the burden of bearing and rearing a family of ten while cooking, housekeeping, gardening, milking, spinning, weaving, making clothes, and helping with the harvests and threshing. »

Such tendencies are significant. They mean that a cyclical change in income is not sufficient to cause any structural change in the farm enterprise. The change in income induced by the intensive development of basic industries located far away from the farm may not be more effective in causing such structural changes ${ }^{1}$. On the other hand, the obvious preference for transportation facilities and household equipment which, according to these recent studies, is shown by Quebec farming families, reveals that they are far from allergic to technical progress.

\section{CONCLUSION}

This essay has stressed the fact that Quebec's agriculture has a relatively low degree of efficiency. Our analysis consisted in scrutinizing the three statistical indices that reflect efficiency: the output per farm, the output per agricultural worker, the output per capita in the farming household. These indices themselves were broken down into their component parts, that is, into the factors associated with efficiency: the demand for agricultural [p. 66] products and the intensity of use of agricultural resources, especially of labour. Whenever there was available information, we have considered these factors in the perspective of the general economic development of the province. This analysis was finally followed by a few remarks concerning the standard of living on Quebec farms.

Such an appraisal of the low productivity of our agriculture in terms of economic factors is in contrast with similar studies which generally overemphasize the cultural or the institutional factors. It is true that one can not understand the behaviour of the Quebec farmer without taking into account his mentality, his traditions and the institutions that constitute his

Changes of the type referred to by D. Gale JOHNSON in Econometric models and agricultural policy, Journal of Farm Economics, vol. XXX, Feb. 1948, No. 1, pp. 117130. 
culture. On the other hand, one should not forget that these activities of the Quebec farmer as well as the way in which he performs them are conditioned by forces of all sorts, technological, economic, political, that are at play outside of his farm, outside of his area and outside of his province. Relevant agricultural policies depend on a full recognition of these facts. The need for intensive research in this perspective is imperative. Given the considerable postwar industrial boom in Quebec and in Canada, it is urgent that our agricultural system be examined thoroughly, in itself and in its vital relationships with the whole of the Canadian and of the continental economy. On this condition depends the success of future agricultural programmes.

Charles LEMELIN 


\section{CHAPTER IV \\ POPULATION PROBLEMS}

Nathan Keyfitz

\section{Retour à la table des matières}

This chapter treats of four aspects of Quebec's demographic development. The first is simply the way in which numbers of people have changed in various parts of the province. As the bounded areas of rural parishes became filled, some people moved out, either to colonize new lands or to live in cities, and the nine censuses of Canada show the rate and extent of population change, parish by parish and county by county.

After summarizing the change in population, we try to find to what extent it is due to people moving, as distinct from being born and dying. The censuses show rapidly increasing numbers in urban places and nearly constant numbers in rural. The second part of this study seeks to infer from the changing numbers of rural and urban residents what flow has taken place. That flow can be estimated if one is willing to make assumptions in regard to death rates and other factors.

Once the number of persons who have gone from country to city is worked out, we focus on the changing pattern of occupations which is both cause and effect of the movement. One can hardly study occupations without going into the division of labour between French and English in the Province of Quebec. The 1951 census will tell some of the consequences of the enormous growth of cities in the 1940's.

The fourth and final section attempts to investigate an aspect of the movement of ideas, of the social change which is occurring contemporaneously with the movement of people from the country to cities. It is well known that taking up city residence changes the outlook of those who move, but a converse of this is not as familiar: what change is taking place among those who are left on farms? 
[p. 68]

\section{THE CHANGING DISTRIBUTION OF POPULATION}

An easy way of seeing the changing pattern of population in the Province of Quebec is from the county distributions of 1871 and 1951. Table 1 lists the counties in groups which have either some economic resemblance or are contiguous to one another. They are the zones drawn up some time ago by the Economic Research Division of the Department of Trade and Commerce. The fifteen such zones present a more quickly understood picture than the full seventy-four counties which form the stub of the census tables.

In the Metropolitan area of Montreal, defined to include Montreal and Jesus Islands and Chambly County, the total population has multiplied by nine over the 80-year period, while the rest of the province has multiplied only by two and a half.

The counties of the Montreal Plains area are divided into two groups, industrial and agricultural. The industrial counties have more than doubled while the agricultural ones have increased by only 10 per cent. A similar contrast is shown within the Eastern Townships zone, where the increase in agricultural counties is 50 per cent while industrial counties trebled. Particular counties can be chosen within these two sub-zones that show the contrast in even more striking degree : Bagot, classed as agricultural, moved from 19,491 in the 1871 count to 19,224 in 1951, while Drummond, classed as industrial, grew from 10,975 to 53,426 .

The same contrast is revealed elsewhere in the province. The industry which came to the St. Maurice valley brought it from 41,362 in 1871 to 179,600 in 1951, while the area north of Quebec City (Laurentides) as well as that south of it (South Shore) did not quite double. The Saguenay rose from 17,000 to 198,000 , an increase which, like that of the St. Maurice, is intimately related to power development.

A study by parishes rather than counties and zones would undoubtedly reveal important features of the relation between population growth and industry. But the gross figures by zones offer sufficient indication that industrialized parts have skyrocketed in population, while agricultural areas have increased slowly or not at all. Before we use these census facts to infer the amount of migration from the farms of Quebec to the cities, it will be useful [p. 69] to note the changes in the proportions French in different parts of the province. 
The changing proportions of French in the Province of Quebec.

The proportion of French origin (i.e. of French ancestry, which is very nearly the proportion French-speaking) in the Province of Quebec increased from 78.0 to 82.0 per cent between 1871 and 1951 .

This reflects the relative rates of natural increase of French and nonFrench, subject to two conflicting limitations : one is that a larger proportion of non-French than French have left the province, from year to year, for other parts of Canada; the other, that few French are included among the immigrants from abroad who have settled in Quebec. This last limitation does not deserve any proof for it is rather obvious from common experience. The first one can be checked by taking statistics as to origin of people now living in the other Canadian provinces and coming from Quebec. If the same proportion of the French-speaking population as of the English-speaking left Quebec regularly, we would expect that the ratio of the French-speaking to the total population would be the same for the Quebec-born who live in the rest of Canada as for those who have remained in Quebec. But this is not so. Taking Ontario, for example, we note for 1941, that of 104,251 persons born in Quebec, 58,563 were of French origin ${ }^{1}$. Although these were more than half, they are a far smaller proportion that the French actually living in Quebec are of the total living in Quebec. Somewhat the same picture is revealed for the provinces west of Ontario.

It is, however, with the way in which the percentage French has varied from one part of the Province of Quebec to another that we are here concerned. The zones already introduced are of use in exhibiting the data on French and English.

The Montreal Plains area which extends south from Montreal increased slightly less in proportion French than the province as a whole, and this applies to the industrial and agricultural subzones separately. Change in the Montreal-Laurentian percentage also showed little deviation from that in the province, but the Eastern Townships show an enormous deviation. The industrial

Census of Canada, 1941, vol. IV, p. 380. 
[p. 70]

TABLE 1

TOTAL AND FRENCH POPULATION OF THE PROVINCE OF QUEBEC, BY COUNTIES AND ZONES, 1871 AND 1951

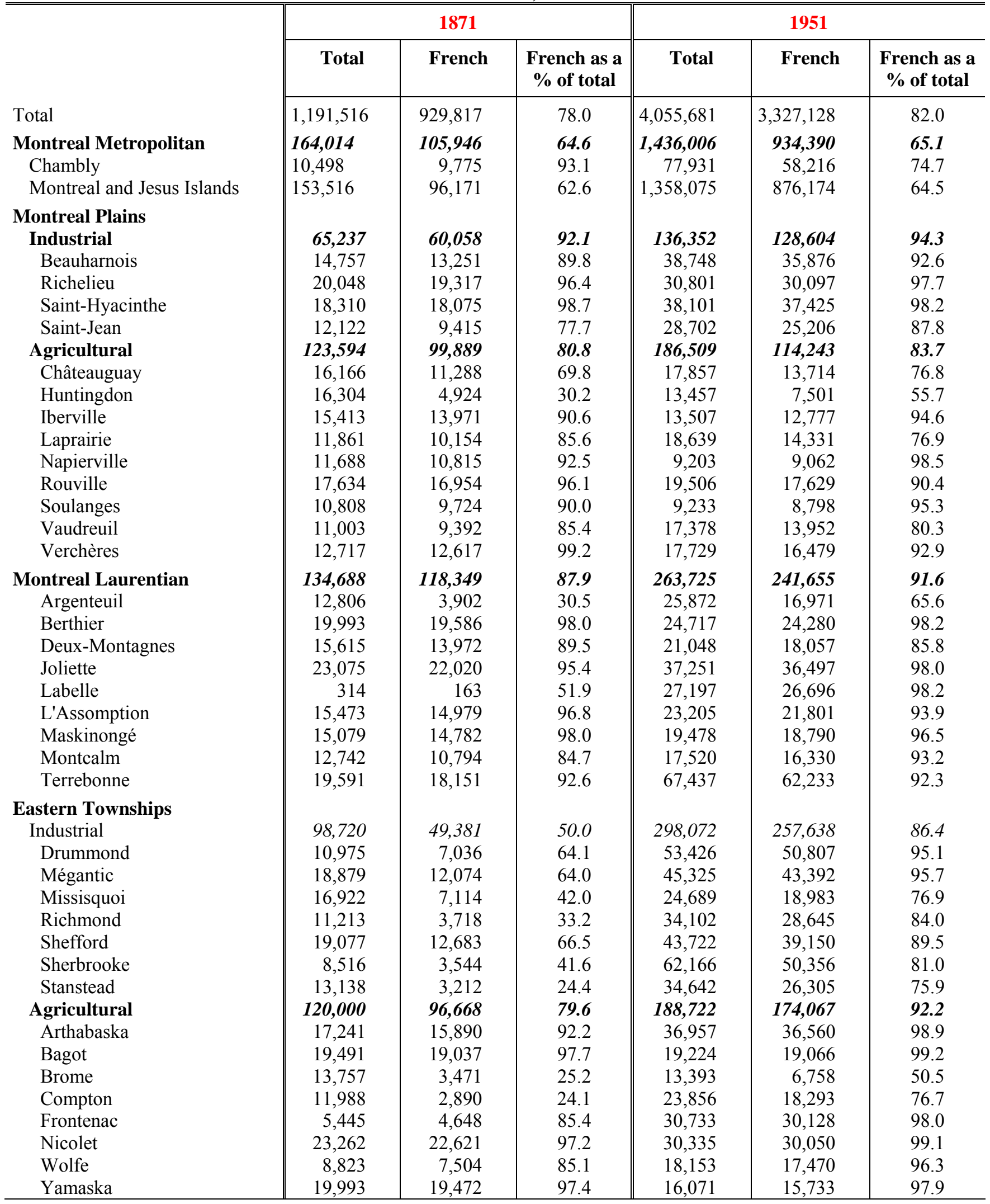


[p. 71]

TABLE 1 (continued)

TOTAL AND FRENCH POPULATION OF THE PROVINCE OF QUEBEC, BY COUNTIES AND ZONES, 1871 AND 1951

\begin{tabular}{|c|c|c|c|c|c|c|}
\hline \multirow{3}{*}{$\begin{array}{l}\text { St. Maurice Valley } \\
\text { Champlain } \\
\text { Saint-Maurice }\end{array}$} & \multicolumn{3}{|c|}{1871} & \multicolumn{3}{|c|}{1951} \\
\hline & Total & French & $\begin{array}{l}\text { French as a } \\
\% \text { of total }\end{array}$ & Total & French & $\begin{array}{c}\text { French as a } \\
\% \text { of total }\end{array}$ \\
\hline & $\begin{array}{l}41,362 \\
21,492 \\
19,870\end{array}$ & $\begin{array}{l}39,842 \\
20,858 \\
18,984\end{array}$ & $\begin{array}{l}93,3 \\
97.1 \\
95.5\end{array}$ & \begin{tabular}{|l}
$\mathbf{1 7 9 , 6 0 0}$ \\
85,745 \\
93,855
\end{tabular} & $\begin{array}{r}\mathbf{1 7 1 , 8 6 8} \\
82,592 \\
89,276\end{array}$ & $\begin{array}{l}96.7 \\
96.3 \\
95.1\end{array}$ \\
\hline $\begin{array}{l}\text { Quebec Metropolitan } \\
\text { Lévis } \\
\text { Quebec }\end{array}$ & $\begin{array}{r}104,137 \\
24,831 \\
79,306\end{array}$ & $\begin{array}{l}78,277 \\
22,706 \\
55,571\end{array}$ & $\begin{array}{l}75.2 \\
91.4 \\
70.1\end{array}$ & \begin{tabular}{|l|}
296,515 \\
43,625 \\
252,890
\end{tabular} & $\begin{array}{r}279,528 \\
42,743 \\
236,785\end{array}$ & $\begin{array}{l}94.3 \\
98.0 \\
93.6\end{array}$ \\
\hline $\begin{array}{l}\text { Quebec Laurentides } \\
\text { Charlevoix East } \\
\text { Charlevoix West } \\
\text { Montmorency No. } 1 \\
\text { Montmorency No. } 2 \\
\text { Portneuf }\end{array}$ & $\begin{array}{l}12,085 \\
22,569\end{array}$ & $\begin{array}{l}\mathbf{4 7 , 1 6 8} \\
15,270\end{array}$ & $\begin{array}{l}93.8 \\
97.8\end{array}$ & $\begin{array}{l}93,101 \\
28,259\end{array}$ & $\begin{array}{l}90,953 \\
27,784\end{array}$ & $\begin{array}{l}97.7 \\
98.3\end{array}$ \\
\hline $\begin{array}{l}\text { South Shore (Que.) } \\
\text { Beauce } \\
\text { Bellechasae } \\
\text { Dorchester } \\
\text { L'Islet } \\
\text { Lotbinière } \\
\text { Montmagny }\end{array}$ & $\begin{array}{r}106,679 \\
23,485 \\
17,697 \\
17,779 \\
13,517 \\
20,606 \\
13,555\end{array}$ & $\begin{array}{l}\mathbf{9 9 , 1 6 1} \\
22,449 \\
17,542 \\
14,996 \\
13,375 \\
17,340 \\
13,449\end{array}$ & $\begin{array}{l}93.0 \\
95.6 \\
99.5 \\
84.3 \\
98.9 \\
84.2 \\
99.2\end{array}$ & $\begin{array}{r}\mathbf{1 8 9 , 1 1 2} \\
54,973 \\
25,332 \\
33,313 \\
22,996 \\
27,985 \\
24,514\end{array}$ & $\begin{array}{r}\mathbf{1 8 6 , 4 8 1} \\
54,445 \\
25,193 \\
32,435 \\
22,532 \\
27,456 \\
24,420\end{array}$ & $\begin{array}{l}98.6 \\
99.0 \\
99.5 \\
97.4 \\
98.0 \\
98.1 \\
99.6\end{array}$ \\
\hline $\begin{array}{l}\text { Saguenay } \\
\text { Chicoutimi } \\
\text { Lac Saint-Jean E. } \\
\text { Lac Saint-Jean W. }\end{array}$ & $\begin{array}{r}17,493 \\
11,812 \\
5,681\end{array}$ & $\begin{array}{r}16,643 \\
11,376 \\
5,267\end{array}$ & $\begin{array}{l}95.1 \\
96.3\end{array}$ & $\begin{array}{r}\mathbf{1 9 7 , 9 1 0} \\
115,904 \\
31,128 \\
50,878\end{array}$ & $\begin{array}{r}\mathbf{1 8 9 , 8 6 8} \\
111,510 \\
29,086 \\
49,257\end{array}$ & $\begin{array}{l}95.9 \\
96.2 \\
93.4 \\
96.8\end{array}$ \\
\hline 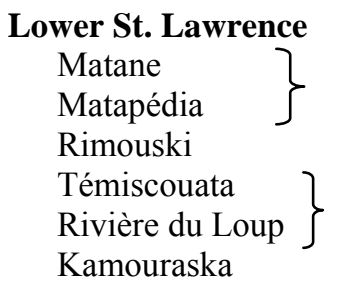 & $\begin{array}{l}71,163 \\
10,022 \\
17,396 \\
22,491 \\
21,254\end{array}$ & $\begin{array}{r}68,804 \\
9,076 \\
16, \mathrm{~S} 81 \\
21,809 \\
21,038\end{array}$ & $\begin{array}{l}96.7 \\
90.6 \\
97.0\end{array}$ & $\begin{array}{r}\mathbf{2 0 9 , 6 2 4} \\
30,243 \\
33,939 \\
53,220 \\
28,175 \\
37,375 \\
26,672\end{array}$ & $\begin{array}{r}206,863 \\
29,751 \\
33,532 \\
52,353 \\
27,832 \\
37,008 \\
26,387\end{array}$ & $\begin{array}{l}98.7 \\
98.4 \\
98.8 \\
98.4 \\
98.8 \\
99.0 \\
98.9\end{array}$ \\
\hline $\begin{array}{l}\text { Gaspé } \\
\text { Bonaventure } \\
\text { Gaspé E. } \\
\text { Gaspé W. } \\
\text { Madeleine Islands }\end{array}$ & $\begin{array}{l}34,652 \\
15,923 \\
\\
18,729\end{array}$ & $\begin{array}{r}22,501 \\
9,545\end{array}$ & $\begin{array}{l}64.9 \\
59.9\end{array}$ & $\begin{array}{r}\mathbf{1 0 3 , 6 5 1} \\
41,121 \\
37,442 \\
15,089 \\
9,999\end{array}$ & $\begin{array}{r}85,699 \\
32,065 \\
29,750 \\
14,720 \\
9,164\end{array}$ & $\begin{array}{l}82.7 \\
78.0 \\
79.5 \\
97.6 \\
91.6\end{array}$ \\
\hline $\begin{array}{l}\text { Gulf } \\
\text { Saguenay }\end{array}$ & $\begin{array}{l}6,487 \\
5,487\end{array}$ & $\begin{array}{l}3,619 \\
3,519\end{array}$ & $\begin{array}{l}64.1 \\
64.1\end{array}$ & $\begin{array}{r}42,661 \\
42,664\end{array}$ & $\begin{array}{l}38,005 \\
33,005\end{array}$ & $\begin{array}{l}77.4 \\
77.4\end{array}$ \\
\hline $\left.\begin{array}{l}\text { Ottawa-Gatineau } \\
\text { Hull } \\
\text { Gatineau } \\
\text { Papineau } \\
\text { Pontiac }\end{array}\right\}$ & $\begin{array}{l}54,125 \\
23,057 \\
14,521 \\
16,547\end{array}$ & $\begin{array}{r}24,806 \\
11,454 \\
9,820 \\
3,532\end{array}$ & $\begin{array}{l}45.8 \\
49.7 \\
67.6 \\
21.3\end{array}$ & $\begin{array}{r}\mathbf{1 4 2 , 6 5 9} \\
57,318 \\
35,264 \\
29,381 \\
20,696\end{array}$ & $\begin{array}{r}110,303 \\
50,690 \\
24,685 \\
25,004 \\
9,924\end{array}$ & $\begin{array}{l}77.3 \\
88.4 \\
70.0 \\
85.1 \\
48.0\end{array}$ \\
\hline $\begin{array}{l}\text { Abitibi } \\
\quad \text { Abitibi } \\
\text { Témiscamingue }\end{array}$ & $\begin{array}{l}- \\
- \\
-\end{array}$ & $\begin{array}{l}- \\
- \\
-\end{array}$ & $\begin{array}{l}- \\
- \\
-\end{array}$ & $\begin{array}{r}\mathbf{1 4 1 , 4 5 8} \\
86,356 \\
55,102\end{array}$ & $\begin{array}{r}121,978 \\
76,904 \\
45,074\end{array}$ & $\begin{array}{l}86.2 \\
89.1 \\
81.8\end{array}$ \\
\hline
\end{tabular}


sub-zone increased from 50.0 to 86.4 per cent French, while the agricultural sub-zone went from 79.6 to 92.2 per cent French.

The St. Maurice valley, almost entirely French from the beginning, dropped very slightly, but the counties of the Laurentians adjacent to Quebec City increased from 93.8 to 97.7 per cent. Metropolitan Quebec increased from 75.2 per cent French to 94.3 per cent, while Montreal hardly changed from its 64.6 per cent of 1871. The Saguenay and Lower St. Lawrence show very slight change, while the Gaspé area shows an increase from 64.9 to 82.7 per cent, a similar change to Saguenay County on the other side of the river.

Particularly striking is the increase in the counties of Quebec near Ottawa where the percentage French rose from 45.8 in 1871 to 77.3 . This is similar to the change in the Ontario county of Russel from 50.4 to 81.9 in the same period.

Table 2 shows, for each zone of the province, the percentage French to the total population for each census from 1871 to 1951 . There is a striking uniformity in the changes which have taken place over the 80 -year period. For example, the industrial portion of the Eastern Townships represents the largest increase, and its per cent French, in every decade without exception, gains between 2.5 and 7 per cent. Oscillations are only to be found in the table where the net change has been very slight. The Montreal Plains industrial counties show an increase from 92.1 to 94.3 per cent over the 80 years and this includes four decades of increase and four of decrease.

Trends as uniform as these would seem to offer opportunities for prediction safer than those presented by most demographic data. It seems clear that if industrialization continues at a high rate, the number of French in urban areas will increase as a result of migration. Whether or not the present rate of industrial growth continues, the differential birth rate demonstrated by other students ${ }^{1}$ will have the effect of increasing the proportion French in both industrial and farm areas of the province.

Sociologists see the spatial distribution of groups such as the French and English in Quebec as the unplanned result of individual movements in which people take up the location to which they

Enid CHARLES, The changing size of the Canadian family, 1941, Census Monograph, Dominion Bureau of Statistics, Ottawa. 
[p. 73]

TABLE 2

PERCENTAGE FRENCH TO TOTAL POPULATION FOR ZONES OF THE PROVINCE OF QUEBEC, CENSUS YEARS 1871-1951

\begin{tabular}{|c|c|c|c|c|c|c|c|c|c|}
\hline & $\begin{array}{c}1871 \\
\%\end{array}$ & $\begin{array}{c}1881 \\
\%\end{array}$ & $\begin{array}{c}1891 \\
\%\end{array}$ & $\begin{array}{c}1901 \\
\%\end{array}$ & $\begin{array}{c}1911 \\
\%\end{array}$ & $\begin{array}{c}1921 \\
\%\end{array}$ & $\begin{array}{c}1931 \\
\%\end{array}$ & $\begin{array}{c}1941 \\
\%\end{array}$ & $\begin{array}{c}1951 \\
\%\end{array}$ \\
\hline Total & 78.0 & 79.0 & 79.7 & 80.2 & 80.1 & 80.0 & 79.0 & 80.9 & 82.0 \\
\hline Montreal Metropolitan & 64.6 & 65.5 & 63.5 & 65.5 & 63.7 & 61.5 & 60.8 & 63.2 & 65.1 \\
\hline $\begin{array}{l}\text { Montreal Plains } \\
\text { Industrial }\end{array}$ & 92.1 & 93.0 & 94.6 & 93.9 & 93.4 & 94.9 & 92.4 & 94.6 & 94.3 \\
\hline Agricultural & 80.8 & 81.5 & 82.1 & 81.7 & 82.9 & 83.2 & 83.6 & 84.6 & 83.7 \\
\hline $\begin{array}{l}\text { Montreal Laurentian } \\
\text { Eastern Townships }\end{array}$ & 87.9 & 88.5 & 89.8 & 90.5 & 91.1 & 91.6 & 91,8 & 91.7 & 91.6 \\
\hline Industrial & 50.0 & 55.3 & 62.1 & 66.2 & 71.6 & 77.3 & 79.8 & 82.8 & 86.4 \\
\hline Agricultural & 79.6 & 79.3 & 82.8 & 84.3 & 86.9 & 88.8 & 89.9 & 91.0 & 92.2 \\
\hline St. Maurice Valley & 96.3 & 95.9 & 96.8 & 97.0 & 93.4 & 95.0 & 95.0 & 95.1 & 95.7 \\
\hline Quebec Metropolitan & 75.2 & 80.0 & 85.2 & 86.0 & 88.8 & 91.4 & 92.6 & 93.1 & 94.3 \\
\hline Quebec Laurentides & 93.8 & 94.8 & 96.4 & 96.5 & 97.2 & 97.3 & 97.0 & 97.8 & 97.7 \\
\hline South Shore (Que.) & 93.0 & 94.7 & 96.3 & 96.0 & 97.7 & 98.1 & 98.4 & 98.7 & 98.6 \\
\hline St. Maurice Valley & 96.3 & 95.9 & 96.8 & 97.0 & 93.4 & 95.0 & 95.0 & 95.1 & 95.7 \\
\hline Saguenay & 95.1 & 97.9 & 99.2 & 98.4 & 99.1 & 98.1 & 95.6 & 96.3 & 95.9 \\
\hline Lower St. Lawrence & 96.7 & 96.6 & 98.5 & 97.0 & 97.9 & 98.6 & 98.1 & 98.0 & 98.7 \\
\hline Gaspé & 64.9 & 68.1 & 68.5 & 72.2 & 74.7 & 75.4 & 77.7 & 81.0 & 82.7 \\
\hline Gulf & 64.1 & 70.9 & 76.1 & 69.6 & 78.5 & 71.6 & 71.4 & 74.2 & 77.4 \\
\hline Ottawa-Gatineau & 45.8 & 50.1 & 56.3 & 60.3 & 65.5 & 69.6 & 72.0 & 75.3 & 77.3 \\
\hline Abitibi & - & - & 53.1 & 45.3 & 65.6 & 85.3 & 81.1 & 83.6 & 86.2 \\
\hline
\end{tabular}

are in some sense best suited. An ecological process known as succession has resulted, as large French families bought farms from the English whose families were smaller, for example in the Eastern Townships ${ }^{1}$. According to one of Horace Miner's informants, about one-quarter of the farmers of St. Denis place two sons on farms in each generation ${ }^{2}$.

For a study of succession in agricultural areas one should ideally have data on individual farms in each locality at each census : whether they are operated by English-speaking or by French-speaking farmers, their family sizes, and hired help, and most particularly, the departures of individual family members. Lacking these, we use the changing residence of the population as a whole [p.

See Aileen D. Ross, Ethnic relations and social structures : A study of the Invasion of French-speaking Canadians into an English-Canadian district, unpublished Ph. D. Thesis submitted to the Department of Sociology, University of Chicago, 1951.

2 Horace R. MINER, St. Denis, a French-Canadian parish, Chicago, The University of Chicago Press, 1939. 
74] to derive estimates of actual movement. The breakdown of the movement into French and English must await further study.

\section{AN ESTMATE OF THE MOVEMENT FROM AGRICULTURE TO INDUSTRY}

The large families of French Canada are seen in many ways. They are the hope of the future, the sign of a robust and vigorous national life, the result of moral principles and the assurance of its continuance. These are not the concern of a purely demographic paper, which takes up numerical aspects only. Many writers have alluded to the fact that if farms are not to be divided, then there must be a single inheritor of the family lands in each generation. The non-inheriting children can remain on the farm as dependents or can leave to found new farms elsewhere, or they can go into non-farm occupations. In Quebec, if they leave the family farm and become farmers elsewhere, they must either buy land, in general from the English, or settle new territories. If they leave agriculture they may become priests or storekeepers, or go into city factory work. The various logical possibilities are shown on Chart 1.

The possibilities of this scheme are rather well known. Not scholars alone but every person and every family deals more or less consciously with the arithmetical paradox arising when lands are inherited by one child and families are large. Any circumstance which affects individual families so directly is sure to-stand out in popular consciousness and to be a favorite subject of discussion and of literature. In this respect, the migration from the land is quite the opposite of the differential in family size (discussed further in Part 4 of this paper), the latter being visible only as a statistical difference between groups whose family sizes on the ground do not look noticeably different.

Although the phenomenon of migration from farms is well known, it has not been measured. No census volume or statistical yearbook shows the number of French-Canadian young men and women leaving their parents' farms. To have objective measurement would be valuable, for the actual amount of movement may turn out to be much greater or much less than estimated by popular and scholarly guesses. In forecasting the amount of industry that 
[p. 75]

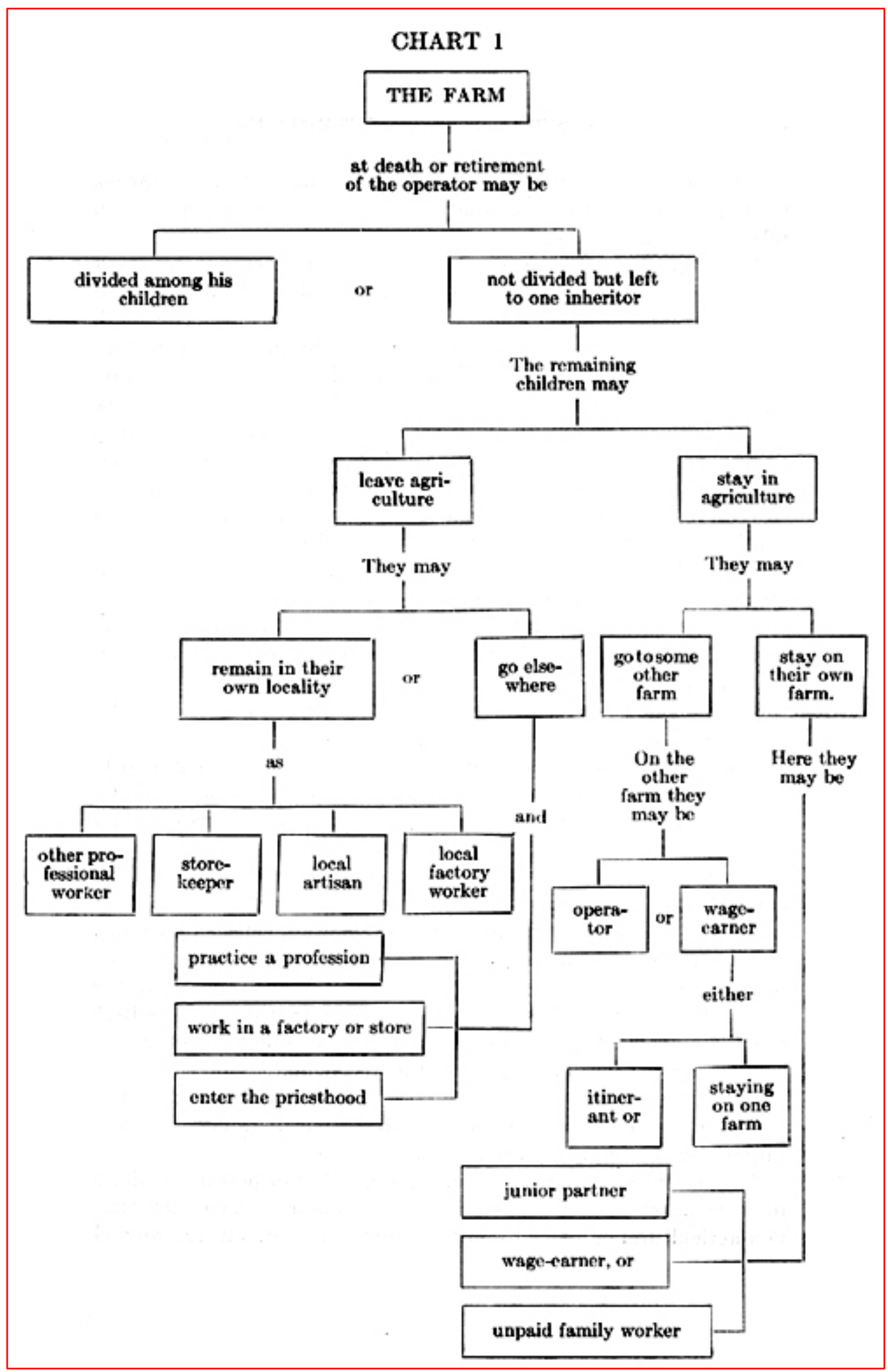

[p. 76] 
will be needed to continue to take up the flow from the farms, we require a knowledge of what the flow has been in the past in relation to past birth rates.

The importance of measurement, however, does not by itself make measurement possible. Statistical results sufficiently accurate to be useful, for the past period with which we are concerned, may simply not exist, - it is possible for such a phenomenon to be lost without trace. This is fortunately not quite the case. The movement from farms with the growth of a factory economy underlies those facts on the number of persons residing in different parts of the province at successive censuses which we have discussed in Part 1 , and by the use of these facts of residence and other data we can infer how many people must have moved. To do so involves assumptions at several points, which we hope to cover with suitable safeguards. It may be well to describe the general strategy before we deal with specific figures.

The essence of the strategy is the use of two more or less independent approaches. Admitting the arbitrariness of the assumptions in any one method, we use two methods and consider that the difference between them is at least a first step in measuring the error of each.

The first method is confined entirely to 13 counties of the province. In all of these, the population is largely engaged in farming. They are the main source of migration to cities, and, what is essential to our calculation, their areas are either fixed through the period from 1871 to 1951 or their populations can be adjusted to the equivalent of fixed areas. Initially we work from the numbers of persons at the several ages found in the counties, census by census, and make assumptions in regard to mortality among them. If, in the ages 15-59 there were 64,000 men in 1901, and if new entrants (from the age group 5-15) less deaths equal 18,000 , and the 1911 population is 68,000 , then 14,000 men must have left. Net migration is thus a residual figure in the reconciliation of successive censuses. It is expanded by the ratio of all farms in the province to those in the 13 counties, to constitute our Estimate 1 of the province-wide migration from farms.

The second approach is through the number of persons working in agriculture and in non-agricultural industry. The fact that non-agricultural industry rose by 748,000 while agriculture dropped [p. 77] 17,000 between 1891 and 1951 should provide a clue to the movement. The change over the whole period, however, conceals a difference that arises very conspicuously in the 1940's. During the war and post-war years, the population in agriculture in the Province of Quebec dropped from 252,000 to 188,000, a decline of 64,000. This decline more than counterbalanced the steady rise that had been shown from 1901, and hence the surprising result that, although the Province of Quebec is almost three times as great in population in 1951 as it was in 1901, it contains fewer men in agriculture. The increase in non-agricultural industry is shown in every one of the thirteen main occupational groups, except fishing and trapping which, like farming, declined sharply. The rise from 79,000 to 237,000 in manufacturing occupations is especially conspicuous (Table 3 ). 
We first estimate the natural increase and the net movement for the province as a whole, and then calculate the proportion of this natural increase which arises on farms. By subtracting from the natural increase on farms the actual increase of farm workers between successive censuses, we obtain our Estimate 2 of the net outflow from agriculture.

If methods 1 and 2 produce similar figures, this is evidence that both are realistic. We will not bother the reader here by giving the arithmetic of their computation but will remain satisfied with presenting Table 4 which shows the results of the two methods ${ }^{1}$.

In total and in five of the eight decades, agreement is surprisingly close. The main discrepancies are shown in 1871-81 and in the decades containing the first and second world wars.

To what extent does the degree of agreement between the two methods check either of them ? Agreement does not demonstrate the suitability of the death rates used, since the same rates entered both calculations. Their appropriateness is however to be judged by the fact that they produce a number of deaths lower in the total of all ages than those officially recorded for the Province of Quebec, rural and urban together. Differentials between the youngest ages of life and older ages, and between rural and urban parts, may be such that the survival rates here used are not too high for the favoured group of rural men of working ages. Any

Full detail of these calculations will be presented in another paper shortly to be published by the author. 
[p. 78]

TABLE 3

MALES GAINFULLY OCCUPIED, $10^{\mathrm{a}}$ YEARS OF AGE AND OVER, BY OCCUPATION GROUP, FOR QUEBEC, 1891 TO 1951

\begin{tabular}{|c|c|c|c|c|c|c|c|}
\hline OCCUPATION GROUP & 1891 & 1901 & 1911 & 1921 & 1031 & 1941 & 1951 \\
\hline $\begin{array}{l}\text { All occupations } \\
\text { Agriculture } \\
\text { Fishing and trapping } \\
\text { Logging } \\
\text { Mining, quarrying } \\
\text { Manufacturing } \\
\text { Construction }\end{array}$ & $\begin{array}{c}399,039 \\
204,552^{b} \\
4,265^{c} \\
4,206 \\
2,119 \\
52058 \\
24,183\end{array}$ & $\left.\begin{array}{r}435,034 \\
194,381 \\
4,317^{d} \\
3,551 \\
1,338 \\
101,884\end{array}\right\}$ & $\begin{array}{c}552,140 \\
201,599 \\
4,431 \\
11,278^{f} \\
5,560^{g} \\
79,288 \\
35,085\end{array}$ & $\begin{array}{r}646,440 \\
217,416 \\
4,005^{e} \\
10,838 \\
4,118 \\
87,793 \\
44,887\end{array}$ & $\begin{array}{r}823,287 \\
225,914 \\
6,418 \\
15,557 \\
6,128 \\
111,352 \\
62,831\end{array}$ & $\begin{array}{r}928,464 \\
251,539 \\
8,081 \\
30,457 \\
9,977 \\
173,288 \\
69,961\end{array}$ & $\begin{array}{r}1,130,194 \\
187,846 \\
5,538 \\
35,935 \\
12,246 \\
237,189 \\
98,510\end{array}$ \\
\hline $\begin{array}{l}\text { Transportation and communication } \\
\text { Trade and finance }\end{array}$ & $\begin{array}{l}15,533 \\
23,788\end{array}$ & $\{45,171\}$ & $\begin{array}{l}34,952 \\
51,131\end{array}$ & $\begin{array}{l}41,263 \\
63,176\end{array}$ & $\begin{array}{l}66,018 \\
78,388\end{array}$ & $\begin{array}{l}79,317 \\
81,684\end{array}$ & $\begin{array}{l}121,643 \\
106,274\end{array}$ \\
\hline $\begin{array}{l}\text { Service } \\
\text { Professional } \\
\text { Personal }\end{array}$ & $\begin{array}{r}23,918 \\
9,332 \\
9,307\end{array}$ & $\begin{array}{l}27,613 \\
\ldots \ldots \ldots . \\
13,202\end{array}$ & $\begin{array}{l}33,729 \\
14,165 \\
15,806\end{array}$ & $\begin{array}{l}46,116 \\
20,388 \\
16,753\end{array}$ & $\begin{array}{l}73,714 \\
29,466 \\
35,021\end{array}$ & $\begin{array}{l}89,967 \\
36,280 \\
41,534\end{array}$ & $\begin{array}{r}134,070 \\
51,500 \\
56,410\end{array}$ \\
\hline $\begin{array}{l}\text { Clerical } \\
\text { Labourers } \\
\text { Not stated }\end{array}$ & $\begin{array}{r}5,998^{h} \\
36,865 \\
1,564\end{array}$ & $\begin{array}{r}15,396^{h} \\
41,241 \\
242 \\
\end{array}$ & $\begin{array}{l}17,219 \\
77,868 \\
\ldots \ldots \ldots \ldots \\
\end{array}$ & $\begin{array}{c}33,086^{i} \\
91,368 \\
2,375\end{array}$ & $\begin{array}{r}43,258 \\
133,368 \\
341\end{array}$ & $\begin{array}{r}49,404 \\
81,038 \\
3,751 \\
\end{array}$ & $\begin{array}{r}69,207 \\
100,242 \\
21,494\end{array}$ \\
\hline
\end{tabular}

a 14 years and over in 1941 and 1950.

$b$ Includes all farmers' sons, 14 years and over, whether or not reported with gainful occupation.

c Does not include nomadic Indians.

$d$ Does not include Indians.

$e \quad$ Does not include Indians on Reserves.

$f \quad$ Includes pulp mill employees.

$g$ Includes almost all mine and smelter employees, except clerical workers.

$h$ Clerical workers in government service were included with service.

i Includes proof readers, shippers, weighmen, and postmen classified elsewhere in other years. The addition of these people to the 1931 figure would have added 18.0 p.c. to the number of males in this occupation group.

$j \quad$ Labourers in all industries except agriculture, fishing, logging and mining are included in this group.

NoTE : Occupations were rearranged as far as possible on the basis of the 1931 classification, though some adjustment of the 1931 grouping was necessary 
[p. 79]

TABLE 4

NET OUT-MIGRANTS FROM FARMS

OF THE PROVINCE OF QUEBEC CALCULATED ON :

\begin{tabular}{l|c|c}
\hline \multirow{2}{*}{} & Method 1 & Method 2 \\
\cline { 2 - 3 } & \multicolumn{2}{|c|}{ 000's } \\
\hline $1871-81$ & 34 & 12 \\
$1881-91$ & 55 & 55 \\
$1991-1901$ & 57 & 70 \\
$1901-11$ & 43 & 48 \\
$1911-21$ & 54 & 57 \\
$1921-31$ & 61 & 34 \\
$1931-41$ & 33 & 114 \\
$1941-51$ & 57 & 430 \\
& & \\
\hline
\end{tabular}

error is probably in the direction of using death rates that are too low, and thus exaggerating the movement off the farms. Errors in mortality, however, even if substantial, can have only a small effect on the movers at the ages in which we are interested. For the ages 15 to 59 , an error in the rates of 20 per cent leads to an error in net migrants of from 5 per cent to 10 per cent.

The two methods used are otherwise independent. Thus the assumption of an equal per cent of male population engaging in gainful activity in farm as in non-farm areas affects Estimate 2 only. The fact that, on the one hand, the 13 farm countries include contain a random sample of the entire farm population, affects Estimate 1 only.

The totals of out-migration for each decade can be expressed in two kinds of rates. Insofar as we are interested in how the migration affects the average farm, we seek the number of migrants per farm per decade. The simplest way of doing this is to relate [p. 80] the migrants of the 13 counties of, Estimate 1 to the number of farms in those counties. The number of farms in these counties as given will serve (Table 5) as the denominator for the ratio of migrants to farms. One-tenth of the ratio of out-migrants to farms (column 3 of Table 5) may be thought of as the annual average number of persons leaving per farm. Its reciprocal, which is shown in column (4), estimates the average interval in years between successive departures.

The sort of minor improvement which has here been disregarded is to use the number of farms at the middle rather than at the end of the intercensal period, for changes in number of farms are small in relation to other difficulties of the computation.

The age distribution of the movers is a by-product of this work which will be required for the second way of regarding the figures of movement from farms. 
TABLE 5

NUMBER OF FARMS AND MIGRANTS IN 13 QUEBEC COUNTIES 1871-1951

\begin{tabular}{l|c|c|c|c}
\hline \hline & Farms & $\begin{array}{c}\text { Out-migrants } \\
15-59 \text { years of age }\end{array}$ & $\begin{array}{c}\text { Average number of } \\
\text { years, elapsing between } \\
\text { successive Out-migrants } \\
\text { on each farm }\end{array}$ & $\begin{array}{c}\text { Average } \\
\text { Number of } \\
\text { Out-migrants }\end{array}$ \\
\hline $\mathbf{1 )}$ & $\mathbf{( 2 )}$ & & $\mathbf{( 3 )}$ & $\mathbf{( 4 )}$ \\
\hline 1871 & 28,629 & $-12,149$ & $(2) /(1) \div 10$ & $1 / 3$ \\
1881 & 33,032 & $-17,135$ & .042 & 24 \\
1891 & 39,554 & $-17,944$ & .052 & 22 \\
1901 & 31,661 & $-14,241$ & .045 & 21 \\
1911 & 38,913 & $-18,406$ & .045 & 17 \\
1921 & 33,839 & $-19,875$ & .047 & 30 \\
1931 & 33,154 & $-10,827$ & .059 & 18 \\
1941 & 35,419 & $-19,390$ & .033 & \\
1951 & 30,972 & \multicolumn{3}{c}{} \\
\hline
\end{tabular}

Table 6 refers to the 13 counties which have been arbitrarily selected and for which absolute numbers do not have significance.

[p. 81] We see that 47 per cent of the out-of-county movers have been between 20 and 29 years of age over the period 1871-1951 and 78 per cent were between 15 and 34 years. There is a small return movement at ages beyond 60 , not shown in the table. Substantial consistency was found in the age pattern for the several decades.

TABLE 6

MALE OUT-MIGRANTS BY AGE GROUP FROM 13 COUNTIES OF QUEBEC, 1871-1951

\begin{tabular}{|c|c|}
\hline Age & $\begin{array}{c}\text { Per cent of Out-migrants } \\
10-59\end{array}$ \\
\hline $10-14$ years & 7.9 \\
\hline $15-19$ years & 14.9 \\
\hline 20-24 years & 22.6 \\
\hline $25-29$ years & 24.9 \\
\hline $30-34$ years & 15.7 \\
\hline $35-39$ years & 6.0 \\
\hline $40-44$ years & 3.4 \\
\hline 45-49 years & 2.5 \\
\hline $50-54$ years & 1.1 \\
\hline $55-59$ years & 1.0 \\
\hline Total & 100.0 \\
\hline
\end{tabular}


Table 7 shows for the 13 counties the number of males enumerated at 15 19 years of age in successive censuses (column 1). One-fifth of this number gives the rate at which the new generation reaches working age each year, and so provides an estimate of the population from which the migrants come. There is no single age at which persons leave farms but since Table 5 has shown that the majority go between the ages of 15 and 34, Table 7 neglects later ages. The numbers of migrants shown for a decade are ten times the average annual number, and the fraction leaving annually can therefore be obtained by dividing one-tenth of the number of migrants by one-fifth of the number of males at ages 15-19 at the beginning of the decade. Since the migrants attain the ages [p. 82] specified through the course of the decade rather than at the beginning, there is a rough correspondence between the time reference of numerator and denominator. The resulting quotients expressed as percentages are shown in column 3 of Table 7.

TABLE 7

\section{MALE MIGRANTS AND MEN COMING OF AGE IN 13 COUNTIES OF ESTIMATE 1}

\begin{tabular}{l|c|c|c}
\hline \hline & $\begin{array}{c}\text { Population 15-19 at } \\
\text { beginning of decade }\end{array}$ & $\begin{array}{c}\text { Migrants 15-24 } \\
\text { during decade }\end{array}$ & $\begin{array}{c}\text { Annual percentage } \\
\text { migration of men } \\
\text { coming of age } \\
\mathbf{( 2 )} \mathbf{~ . 5}\end{array}$ \\
\hline & $\mathbf{( 1 )}$ & $\mathbf{( 2 )}$ & $\mathbf{( 3 )}$ \\
\hline $1871-81$ & 12,658 & 9,998 & 39.5 \\
$1881-91$ & 13,141 & 14,349 & 54.6 \\
$1891-1901$ & 13,447 & 15,115 & 56.2 \\
$1901-11$ & 13,179 & 12,490 & 47.4 \\
$1911-21$ & 13,830 & 15,310 & 55.4 \\
$1921-31$ & 15,088 & 16,251 & 53.9 \\
$1931-41$ & 15,583 & 10,004 & 32.1 \\
$1941-51$ & 17,126 & 16,678 & 48.7 \\
\hline \multicolumn{1}{c|}{ Total 1871-1951 } & $\mathbf{1 1 4 , 0 5 2}$ & $\mathbf{1 1 0 , 1 9 5}$ & $\mathbf{4 8 . 3}$ \\
\hline
\end{tabular}

The ratios average about 48 per cent. In other words, one farm boy out of two leaves his county between the ages of 15 and 34 . The smaller numbers leaving in the first decade 1871-81 may be due to the filling up of the counties or it may be an error, since our Estimate 2 shows a much larger number in this decade. After this, the per cent leaving is fairly level at about 50 from 1881 to 1931. During the 30's, there was a drop which constitutes the backing up of population on the farms ${ }^{1}$ due to lack of jobs in industry.

Referred to in Everett-C. HUGHES, French Canada in transition, Chicago, University of Chicago Press, 1941. 


\section{[p. 83]}

Miner's description of the family cycle has often been referred to. It will be quoted again here in interpreting the figures of the outflow from farms : «...By the time the young couple have been married eight years, they have had five children, one of whom had died. The eldest child is seven years old, the youngest a babe in arms. The family cycle is so regular that native expression gives voice to such a remark as "He is just a young man. He has only four or five children." ...In eight more years the father is forty-two and the couple has had ten children, three of whom have died. The eldest sons are helping in the field, and there is no labor problem. By this time the father has begun to think seriously of plans for the future of his children, for whom he is responsible. He will ultimately have to arrange for six children. Obviously, one of these, a boy, will inherit the parental land ... When the young man inherits, the cycle recommences ${ }^{1}$. »

Miner sums up the outlooks of the ten children : «... four die before reaching twenty-five years; one inherits the paternal land; one marries a farmer; and one (if a boy) enters priesthood, or profession, or (if a girl) enters convent, becomes a school teacher, or marries a professional man. There are still three children unaccounted for. The father, during his management of the farm, although passing on the responsibility to his successor in the latter's first years, tries to buy another farm or save the money for a son to get a farm somewhere. A local informant estimated that one-quarter gives the boy some technical training or sends him to cities or industrial centers where he can get work ${ }^{2}$. »

It is from among the three children unaccounted for that the migrants must come. Miner later refers to the unmarried population of the parish : men in this unmarried population may become hired hands to help families at the stage of the cycle where the siblings of the inheritor have left and his children are not yet old enough to take part in farm work.

These statements seem broadly consistent with our calculation of about 50 per cent of young men leaving the county of their birth and a young man leaving each farm every 20 years. However, ours is an average, not a typical, figure ; it takes in farms which [p. 84] have no children at all; it includes all farms, English as well as French. Allowance for these and other crudities awaits further analysis.

http://classiques.uqac.ca/classiques/hughes_everett_cherrington/hughes_ec.html

Horace MINER, op. cit., pp. 81-83.

http://classiques.uqac.ca/contemporains/miner_horace/miner_horace.html

Ibid. 


\section{THE CHANGING DIVISION OF LABOUR}

Our third section follows the men who left farms to enter the factories and other urban economic activity. Much scholarly work has been done on this topic, including useful interpretation of available statistics. The encouragement and example of Professor Everett-C. Hughes have resulted in such studies as those of Roy and Jamieson, and students of the Laval Faculty of Social Sciences have studied specific industries.

The fundamental treatment of the division of labour between French and English is by Professor Hughes himself ${ }^{1}$. He considers a factory not only as the site of a process of production, but as a social system as well. This means that the notion of "qualification " for the job must be extended to include other items than mere technical competence. If qualification actually meant technical competence only, if the directors of an enterprise acted in robot-like fashion to maximize profits, each time a vacancy occurred, they would consider all candidates offering themselves at the given salary, they would have them arranged exactly in order of skill at the specific work, and would pick the top one from the list. This conception of the method of selection is itself a product of culture, and however much we all subscribe to the culture which prescribes it as the ideal, sociologists must attempt a more descriptive statement, an objective examination of the choices which are not purely objective in the profit-maximizing sense.

The qualifications begin of course with the technical knowledge which is gained in schools; they also involve the experience gained on the job as well as such qualities as initiative and reliability of performance. Finally, they include what is implied by the need to fit into a social organization. For some posts, as Professor Hughes points out, the criteria of selection may include that the appointee be of such background that he can be safely and com-[p. 85] fortably entertained at dinner. For other posts, such social qualifications are not important. When the confidence of management is primary to the job, the appointee tends ethnically to resemble management. When it is the confidence of staff that is primary to the job, the appointee resembles staff. The suitability of a person is then not established once, for all purposes, but in a series of stages, of separate gestures, for example in the form of promotions, each of which constitutes, in Hughes' words, a « vote of confidence. » These are some of the factors which operate in our bi-cultural industrial situation.

The existing studies which generalize to Quebec or the city of Montreal ${ }^{2}$ show the consequent division of labour at the 1931 census. It was one in

Op. cit.

S. M. JAMIESON, French and English in the institutional structure of Montreal, A study of the social and economic division of labour, M. A. Thesis, McGill University, 1938. 
which « the French Canadians are, as French human geographers would say, the passive element in the human geography of this region. The English are the active, episodic, catastrophic element... ${ }^{1} \gg$ My interest here is the division of labour between French and English in Canada as a whole, and I have used the 1941 census to see what change took place through the 1930's.

The news on the 1930's can be discussed in the great detail of 400 occupation classes. Table 8 is confined to highlights. In transport, for example, the railway running trades, in which the French have not been well represented, showed little change between 1931 and 1941. French chauffeurs and taxi drivers, on the other hand, who already constituted 42 per cent of the occupation, moved up to 44 per cent ; French truck drivers from 24 per cent to 30 per cent; French messengers from 24 per cent to 38 per cent. In commercial occupations, the per cent of storekeepers who were French showed little change, but the French increased relatively as sales clerks and diminished as commercial travellers.

The professional services are of central interest. Among chemists and engineers, there was no appreciable change in the proportion French, while the traditional fields of doctor, lawyer, notary and 
[p. 86]

TABLE 8

PERCENTAGE FRENCH TO TOTAL FOR SELECTED OCCUPATIONS, CANADA, 1931 AND 1941

\begin{tabular}{|c|c|c|c|c|c|c|}
\hline & \multicolumn{3}{|c|}{1931} & \multicolumn{3}{|c|}{1941} \\
\hline & Total & French & $\%$ & Total & French & $\%$ \\
\hline All occupations ${ }^{a}$ & $3,260,014$ & 808,490 & 24,8 & $3,353,416$ & 939,769 & 28.0 \\
\hline Agriculture & $1,107,766$ & 275,738 & 24.9 & $1,064,847$ & 302,004 & 28.4 \\
\hline Farmers and stock raisers & 626,112 & 141,070 & 22.5 & 630,709 & 158,155 & 25.1 \\
\hline Farm labourers & 478,632 & 134,244 & 28.0 & 431,102 & 143,490 & 33.3 \\
\hline Fishing, Hunting and Trapping & 47,408 & 10,067 & 21.2 & 61,126 & 11,047 & 21.6 \\
\hline Fishermen & 33,620 & 9,017 & 26.8 & 33,273 & 9,904 & 29.8 \\
\hline Hunters, trappers, guides & 13,798 & 1,050 & 7.6 & 17,853 & 1,143 & 6.4 \\
\hline Logging & 43,996 & 18,614 & 42.3 & 80,248 & 40,395 & 60.3 \\
\hline Owners and Managers. & 2,463 & 851 & 34.6 & 2,004 & 799 & 39.9 \\
\hline Foremen & 912 & 384 & 42.1 & 1,321 & 663 & 50.2 \\
\hline Foresters and timber cruisers & 3,182 & 1,190 & 37.4 & 2,923 & 1,292 & 44.2 \\
\hline Lumbermen & 37,438 & 16,189 & 43.2 & 74,000 & 37,641 & 50.9 \\
\hline Mining and Quarrying & 58,685 & 7,910 & 13.5 & 71,861 & 13,077 & 18.2 \\
\hline Owners and Managers & 1,249 & 131 & 10.5 & 1,360 & 93 & 6.8 \\
\hline Foremen & 2,001 & 272 & 13.6 & 2,804 & 410 & 14.6 \\
\hline Manufacturing & 394,823 & 94,055 & 23.8 & 561,001 & 164,886 & 27.6 \\
\hline Owners and Managers & 36,936 & 7,691 & 20.8 & 35,499 & 6,506 & 18.3 \\
\hline Foremen ${ }^{b}$ & 17,674 & 4,323 & 24.5 & 28,555 & 6,735 & 23.6 \\
\hline Bakers & 10,539 & 3,256 & 30.9 & 10,793 & 3,713 & 34.4 \\
\hline Machinists - metal & 32,476 & 6,240 & 19.2 & 42,924 & 10,001 & 23.3 \\
\hline Printers & 15,576 & 2,177 & 14.0 & 15,997 & 3,583 & 22.4 \\
\hline Stationary enginemen & 21,116 & 2,821 & 13.4 & 29,792 & 6,760 & 22.7 \\
\hline Construction & 202,970 & 59,565 & 29.3 & 212,716 & 70.969 & 33.4 \\
\hline Owners and Managers & 13,012 & 3,022 & 23.2 & 9,357 & 2,000 & 21.4 \\
\hline Foremen & 5,381 & 1,360 & 25.3 & 4,481 & 1,293 & 28.9 \\
\hline Carpenters & 81,264 & 26,457 & 32.6 & 89,787 & 32,682 & 36.4 \\
\hline Painters, decorators, glaziers & 34,827 & 10,086 & 29.0 & 38,416 & 13,138 & 34.2 \\
\hline Plumbers and pipe fitters & 17,471 & 5,365 & 30.7 & 18,937 & 6,439 & 34.0 \\
\hline Transportation and Communication & 271,244 & 61,746 & 22.8 & 294,800 & 80,754 & 27.4 \\
\hline Owners, officials, managers. & 8,397 & 1,287 & 15.3 & 8,299 & 1,080 & 13.0 \\
\hline Chauffeurs and taxi drivers & 15,388 & 6,398 & 41.6 & 15,090 & 6,567 & 43.5 \\
\hline Locomotive engineers & 7,920 & 1,021 & 12.9 & 7,088 & 907 & 12.8 \\
\hline Locomotive firemen & 5,948 & 919 & 15.5 & 5,235 & 909 & 17.4 \\
\hline Longshoremen and stevedores & 4,816 & 2,093 & 43.5 & 9,476 & 4,168 & 44.0 \\
\hline Messengers & 12,880 & 3,041 & 23.6 & 11,711 & 4,418 & 37.7 \\
\hline Sectionmen and trackmen & 23,587 & 3,871 & 16.4 & 24,422 & 4,928 & 20.2 \\
\hline Teamsters \& carriage drivers & 22,286 & 6,879 & 30.9 & 18,720 & 6,515 & 34.8 \\
\hline Truck drivers & 43,698 & 10,671 & 24.4 & 80,403 & 23,799 & 29.6 \\
\hline
\end{tabular}

\footnotetext{
${ }^{\text {a }}$ Not including males in « not stated » classification.
}

${ }^{\mathrm{b}}$ Including inspectors, testers-chemicals and inspectors, gaugers-metal. 
[p. 87]

TABLE 8 (continued)

PERCENTAGE FRENCH TO TOTAL FOR SELECTED OCCUPATIONS, CANADA 1931 AND 1941

\begin{tabular}{|c|c|c|c|c|c|c|}
\hline & \multicolumn{3}{|c|}{1931} & \multicolumn{3}{|c|}{1941} \\
\hline & Total & French & $\begin{array}{c}\text { Percent } \\
\text { age }\end{array}$ & Total & French & $\begin{array}{c}\text { Percent } \\
\text { age }\end{array}$ \\
\hline Trade & 269,799 & 65,472 & 21.4 & 266,023 & 62,806 & 23.6 \\
\hline $\begin{array}{l}\text { Owners, managers, dealers - } \\
\quad \text { retail }\end{array}$ & 94,644 & 20,698 & 21.9 & 100,756 & 23,486 & 23.3 \\
\hline $\begin{array}{l}\text { Owners, managers, dealers - } \\
\text { wholesale }\end{array}$ & 13,336 & 1,516 & 11.4 & 20,188 & 2,871 & 14.2 \\
\hline Commercial travellers & 16,495 & 5,465 & 33.1 & 29,882 & 6,575 & 22.0 \\
\hline Salespersons in stores & 100,537 & 22,680 & 22.6 & 81,270 & 24,282 & 29.9 \\
\hline Finance & 36,252 & 6,333 & 17.5 & 30,576 & 5,783 & 18.9 \\
\hline Owners, managers, officials & 8,557 & 1,368 & 16.0 & 8,241 & 1,338 & 16.2 \\
\hline Insurance agents & 17,049 & 3,795 & 22.3 & 14,571 & 3,596 & 24.7 \\
\hline Service & 270,673 & 58,873 & 21.8 & 308,550 & 76,951 & 24.9 \\
\hline Architects & 1,296 & 234 & 18.1 & 1,186 & 271 & 22.8 \\
\hline Artists and art teachers & 1,909 & 296 & 15.5 & 2,328 & 404 & 17.4 \\
\hline Authors, editors, journalists & 2,880 & 432 & 15.0 & 3,434 & 731 & 21.3 \\
\hline Clergymen and priests & 12,662 & 3,695 & 29.2 & 14,077 & 4,514 & 32.1 \\
\hline Dentists & 4,007 & 674 & 16.8 & 3,695 & 727 & 19.7 \\
\hline Draughtsmen and designers & 4,596 & 526 & 11.4 & 5,596 & 855 & 15.3 \\
\hline Engineers - professional & 15,818 & 1,938 & 12.3 & 18,547 & 2,378 & 12.8 \\
\hline Lawyers and notaries & 8,004 & 2,081 & 26.0 & 7,791 & 2,249 & 28.9 \\
\hline Physicians and surgeons & 9,817 & 2,204 & 22.5 & 10,339 & 2,470 & 23.9 \\
\hline Professors and college principals & 2,941 & 1,570 & 53.4 & 3,858 & 2,208 & 57.2 \\
\hline Teachers - schools & 18,274 & 4,649 & 25.4 & 21,988 & 5,519 & 25.1 \\
\hline Policemen and detectives & 10,900 & 2,799 & 25.7 & 15,960 & 4,711 & 29.5 \\
\hline Postmasters & 2,439 & 463 & 19.0 & 3,205 & 731 & 22.8 \\
\hline Postmen and mail carriers & 6,700 & 1,640 & 24.5 & 7,310 & 2,044 & 28.0 \\
\hline Owners and managers - hotels & 5,399 & 1,722 & 31.9 & 5,945 & 1,826 & 30.7 \\
\hline Owners and managers - restaurants & 9,765 & 2,368 & 24.2 & 10,859 & 3,535 & 32.6 \\
\hline Barbers, hairdressers, manicurists & 16,368 & 5,406 & 33.0 & 14,889 & 5,137 & 34.5 \\
\hline Cooks & 17,832 & 3,300 & 18.5 & 17,947 & 4,263 & 23.9 \\
\hline Guards and caretakers n. e. s & 13,411 & 3,663 & 27.3 & 20,815 & 5,821 & 28.0 \\
\hline Janitors and sextons & 14,691 & 1,878 & 12.8 & 19,221 & 3,628 & 18.9 \\
\hline Laundrymen & 9,607 & 1,225 & 12.8 & 5,419 & 732 & 13.5 \\
\hline Lodging and boarding housekeepers & 1,742 & 299 & 17.2 & 2,208 & 366 & 16.6 \\
\hline Waiters & 11,203 & 2,149 & 19.2 & 13,735 & 3,728 & 27.1 \\
\hline Clerical & 141,191 & 26,876 & 19.0 & 159,779 & 34,586 & 21.6 \\
\hline Accountants and auditors & 46,405 & 9,133 & 19.7 & 46,040 & 11,258 & 24.5 \\
\hline Book-keepers and cashiers & & & & & & \\
\hline Office clerks & 94,673 & 17,340 & 18.3 & 110,043 & 22,397 & 20.4 \\
\hline Shipping clerks & 15,045 & 2,281 & 15.2 & 23,044 & 4,628 & 20.1 \\
\hline $\begin{array}{l}\text { Labourers (not in agriculture, } \\
\text { fishing, logging or mining) }\end{array}$ & 428,062 & 133,400 & 31.2 & 251,889 & 86,511 & 34.3 \\
\hline
\end{tabular}


priest showed a rise about equal to the gain in the proportion of the labour force which is French. Though the proportion of engineers who were French did not increase, the percentage of draughts-men rose from 11 to 15 . Going further from the old professions, we find that policemen, detectives, and postmasters increased appreciably in the proportion French, and in such services as janitors, waiters, and cooks the proportion French increased substantially.

In the clerical group taken as a whole, the proportion of French increased slightly less than it did among the gainfully occupied. Accountants and bookkeepers however increased from 20 to 25 per cent French, shipping clerks from 15 to 20 per cent. Unfortunately, a class such as « accountants and bookkeepers » lumps individuals of very different income and prestige, and through the possibility of different movements of French and English within it, we are prevented from drawing any very precise conclusion.

Although the statement is not entirely unambiguous, it appears that the description of a division of labour whereby the French Canadians were left behind in business and industry applied no less 10 years ago than it did 20 years ago. However, the 1930's were a time of regression and stand in sharp contrast to the 1940's. Table 9 indicates the relative and absolute decline of agriculture in every province during the 1940's. Quebec dropped from 27 to 17 per cent agriculture, reflecting an extraordinary alteration in the scheme of things, an unprecedented change to take place in a single decade. We therefore await with special interest the 1951 census results showing occupation by origin.

\section{THE INFLUENCE OF CITIES ON FARM FAMILY SIZE}

The influence which the city exerts on the countryside is not easily measured, but some attempt to measure it seems a necessary complement to our discussion. We have already found from censuses the degree to which the cities of the Province of Quebec recruit new population from the countryside. Our last problem is to see if the census can tell us about the effect which industrialization and the increasing size of cities have on those who remain in the countryside. That the city has an effect on the minds and behaviour of those who have moved into it is beyond discussion : 
[p. 89]

TABLE 9

PERCENTAGE OF GAINFULLY OCCUPIED MALES IN AGRICULTURE,
FOR CANADA AND PROVINCES, 1941 AND 1951

\begin{tabular}{l||r|r|r||r|r|r}
\hline \multicolumn{1}{c||}{} & \multicolumn{3}{c||}{$\mathbf{1 9 4 1}$} & \multicolumn{3}{c}{$\mathbf{1 9 5 1}$} \\
\cline { 2 - 7 } \multicolumn{1}{c|}{ ProviNCE } & $\begin{array}{c}\text { Total } \\
\text { gainfully } \\
\text { occupied }\end{array}$ & $\begin{array}{c}\text { Gainfully } \\
\text { occupied in } \\
\text { agriculture }\end{array}$ & $\mathbf{\%}$ & $\begin{array}{c}\text { Total } \\
\text { gainfully } \\
\text { occupied }\end{array}$ & $\begin{array}{c}\text { Gainfully } \\
\text { occupied in } \\
\text { agriculture }\end{array}$ & \% \\
Canada & $3,363,111$ & $1,064,847$ & 31.7 & $4,121,832$ & 797,874 & 19.4 \\
Newfoundland & - & - & - & 89,460 & 3,567 & 4.0 \\
Prince Edward Island & 26,088 & 16,350 & 62.7 & 28,156 & 12,693 & 45.1 \\
Nova Scotia & 153,941 & 36,934 & 24.0 & 178,087 & 22,977 & 12.9 \\
New Brunswick & 119,341 & 41,136 & 34.5 & 134,953 & 26,211 & 19.4 \\
Quebec & 928,464 & 251,539 & 27.1 & $1,130,194$ & 187,846 & 16.6 \\
Ontario & $1,140,105$ & 264,914 & 23.2 & $1,439,966$ & 193,795 & 13.5 \\
Manitoba & 215,705 & 90,774 & 42.1 & 232,296 & 70,430 & 30.3 \\
Saskatchewan & 273,122 & 184,244 & 67.5 & 251,077 & 141,736 & 56.5 \\
Alberta & 247,622 & 138,814 & 56.1 & 291,269 & 111,745 & 38.4 \\
British Columbia & 258,723 & 40,142 & 15.5 & 346,374 & 26,874 & 7.8 \\
9 Provinces & $\mathbf{3 , 3 6 3 , 1 1 1}$ & $\mathbf{1 , 0 6 4 , 8 4 7}$ & $\mathbf{3 1 . 7}$ & $\mathbf{4 , 0 3 2 , 3 7 2}$ & $\mathbf{7 9 4 , 3 0 7}$ & $\mathbf{1 9 . 7}$ \\
\hline
\end{tabular}

what we seek here is its effect on those who remain on the farm.

This point could be attacked in many ways. The anthropologist, for example, might fruitfully examine changes through time in architectural taste, in clothing fashions, in forms of amusement. So far as we are concerned, the data which we must use are simply the number of children born to mothers, as reported in the 1941 census. The specific question that we put to the data is whether the families living near cities are smaller than those further away. If family size in the countryside increases with distance from cities, among families that are the same in income, education, etc., then we have a measure of the extent to which influence cities is pervading the countryside. Several methods of investigation, more or less independent, were used to determine this fact, and their agreement is sufficient for a reasonably firm conclusion.

While this topic is under study, it is convenient to examine a related question, namely whether the Canadian of French ancestry is influenced by neighbours who are English-speaking. It may be assumed that the French who live near the English have more [p. 90] likelihood of contact with them than those who live farther away, and that if any difference in behaviour between the " near » French and the " far » ones can be found, that difference will be a consequence of the difference in contact. The inference, once again, depends on ensuring that the "near» and «far» French are similar in respects other than distance from the English, and we shall try to ensure this as much as it is possible. 
In the same way, people who live near cities may be expected to be relatively exposed to the social psychological influences of urban life : a farmer who lives within a few miles of a city visits it more often, has more friends and relatives who live in it, receives more visitors from it, enters more often into commercial contacts with city people, than a farmer who lives farther away. If this is not true in each individual case, it is certainly true on the average.

Perhaps the most notable instance of diffusion in history is the contemporary spread of ways, identified as "modern », which follow the industrial revolution into corners of the world where traditional ways have been dominant. Extensive data have been presented on one aspect of this many-sided diffusion, namely change in family size. Most writers of differential fertility, whether sociological or biological in their orientation, would recognize some affiliation of their subject to the industrial revolution.

Throughout western countries, it has been the better-off people, the urban, the educated, who have most quickly and completely taken on the smallfamily pattern. This route of acceptance recalls the movements of fashion whose travel, down prestige gradients, has been noted by Sapir ${ }^{1}$.

French-Canadian families have always been large and they are still large. A rate of 63 births per thousand inhabitants was shown in the 1660's, and the level stayed not much below this until the middle of the 19 th century ${ }^{2}$. In the past 100 years, there has been some drop : the lowest point, 25 per thousand, was reached in the 1930's, while the post-war period has been consistently around 30. The trend of births is made somewhat obscure by reason of the extraordinary decline in the thirties and the recovery in the forties. The following table shows, however, [p. 91] that French and total birth rates have, to some extend, come together over the past 20 years.

Edward SAPIE, Art fashion, Encyclopedia of the Social Sciences.

Province of Quebec Statistical Year-Book, 1913. 
TABLE 10

BIRTH RATES FOR FRENCH AND OTHER ORIGINS FOR CANADA, 1931-51

\begin{tabular}{l|r|r|r}
\hline \hline & All origins & French & Others \\
\hline $\mathbf{1 9 3 1}$ & & & \\
Female Population 15-44 years & $2,306,528$ & 651,188 & $1,655,340$ \\
Births & 240,473 & 92,332 & 148,141 \\
Rate per 1,000 population & 104 & 142 & 89 \\
$\mathbf{1 9 4 1}$ & & & \\
Female Population 15-44 years & $2,651,228$ & 822,691 & $1,828,537$ \\
Births & 255,317 & 101,915 & 153,402 \\
Rate per 1,000 population & 96 & 124 & 84 \\
$\mathbf{1 9 5 1}$ & & & \\
Female Population 1544 years & $3,103,807$ & 981,761 & $2,122,046$ \\
Births & 357,907 & 135,501 & 222,406 \\
Rate per 1,000 population & 115 & 138 & 105 \\
\hline
\end{tabular}

The decline from pioneer days has undoubtedly been associated with the growth of cities, and the moving into occupations where the family has a different significance from what it has on the farm. However, this city-country difference has already been treated by both English and French writers ; as for us, we want to take up the more specialized topic of the differences that are to be found within the farm population itself.

It seems safe to assume that a new trait has a definite course through a society. It starts among the people who are on the sensitive "margin » of the society, that is, those who are psychologically more receptive, and eventually spreads into the "interior ». Our hypothesis is that, for families with a given source of livelihood, the margin has a geographical location.

[p. 92]

First, we have calculated a number of correlations of country averages, using published census tabulations. Three kinds of average for family size and two measures of distance were used; correlations were in some cases calculated both on the original measures and on their transformation into ranks. The overall result was a partial correlation of about .50, that is, about .25 of the intercounty variance of family size was explained by distance from cities, when income, education, and age at marriage were held constant.

However, the research not only required a better control of extraneous variables than the census tabulations permit, but it required an answer controlling these, as far as possible, for individual families, not for counties. To secure this, a very small sample of 1,056 families was tabulated by hand. 
Because the families were selected at random, it is possible to draw inferences from the sample with known probability of error. Total children ever born to women aged 45-74, i.e. whose families were approximately complete, was the measure of fertility, and the sample was composed partly of families living near cities and partly of those living far from cities. The entire tabulation was confined to a homogeneous group : complete families in which both husband and wife were French, Catholic, born and now living on a farm, and the husband a farm operator. Within this group, dichotomous classifications were made for present age of wife (45-54 and 55-74), age at marriage (-20 and 2024), and years of schooling ( -7 and 7 and over), so that the effect of these could be balanced out between the families near cities and those far away, without narrowing the scope of the investigation. Because income was not on the same schedule, it could not be matched for the individual farmers but only for the counties in which they lived. Two degrees of association with the English were distinguished by dividing the French families into those who lived in an enumeration area containing five or more English-speaking families, and those living in an area containing fewer than five ${ }^{1}$.

Before analyzing the 1,056 cases drawn into the sample, it was noted that the average of children ever born to mothers in distant [p. 93] places was 10.7 and in near places 9.1, a difference of 1.6 children (see Table 11). Because of the unequal numbers in the sub-classes however, this difference is not independent of the ages at marriage, etc. It would be arithmetically somewhat difficult to estimate the average number of children in near and far places separately, but the estimate of the difference between them is easily ascertained and is all that the problem requires. It turns out to be 1.28 children with a standard error of about .27 .

Although it is impossible to establish that distance is the cause of the difference, as can be done in an experiment where families are allocated at random, yet, it may be said with high probability that the difference secured in the sample is the same in direction as that which would be found by examination of all of the families in the two sets of counties. In other words, the strength or the weakness of the inference is not in the sample size, but in the completeness with which variables which might be confounded with distance, have been eliminated.

Significant results were attained, not only on distance but on three of the other five variables - age at marriage, income, and years of schooling. Coresidence with the English, on the other hand, does not seem to be related to family size. Evidently it is not a trait which is carried in any important degree through the sorts of contacts which exist between English and French.

We now consider the meaning of our statistical result in broader terms, starting with the notion of a " route of acceptance » of new culture traits. It is known that in general they go from rich to poor, from city to country, etc. The change in family size which is spreading with the contemporary spread of the

For a more elaborate account of the method used in this analysis, see Nathan KEYFITZ, $A$ factorial arrangement of comparisons of family size, American Journal of Sociology, vol. LVIII, No 5, March 1952, pp. 470-480. 
industrial revolution, as one of the few traits whose movement among sections of the population is statistically documented, serves as a tracer of new traits in general.

This part of our investigation is concerned with whether the route of acceptance has a spatial dimension. It is not to be expected that a space differential would be detectable in a mobile society. In a less mobile one, especially in that section of it which is on the land where the impact of changed ways of doing things is cushioned by an agriculture at least partly independent of the market, it is a priori likely that the handing on of new traits is to groups farther from the city by those nearer. 
[p. 94]

TABLE 11

RESULT OF HAND COMPILATION OF 1,056 FAMILIES FROM 1941 CENSUS SCHEDULES : SHOWING FOR EACH CELL AVERAGE NUMBER OF CHILDREN EVER BORN AND NUMBER OF FAMILIES ON WHICH AVERAGE IS BASED

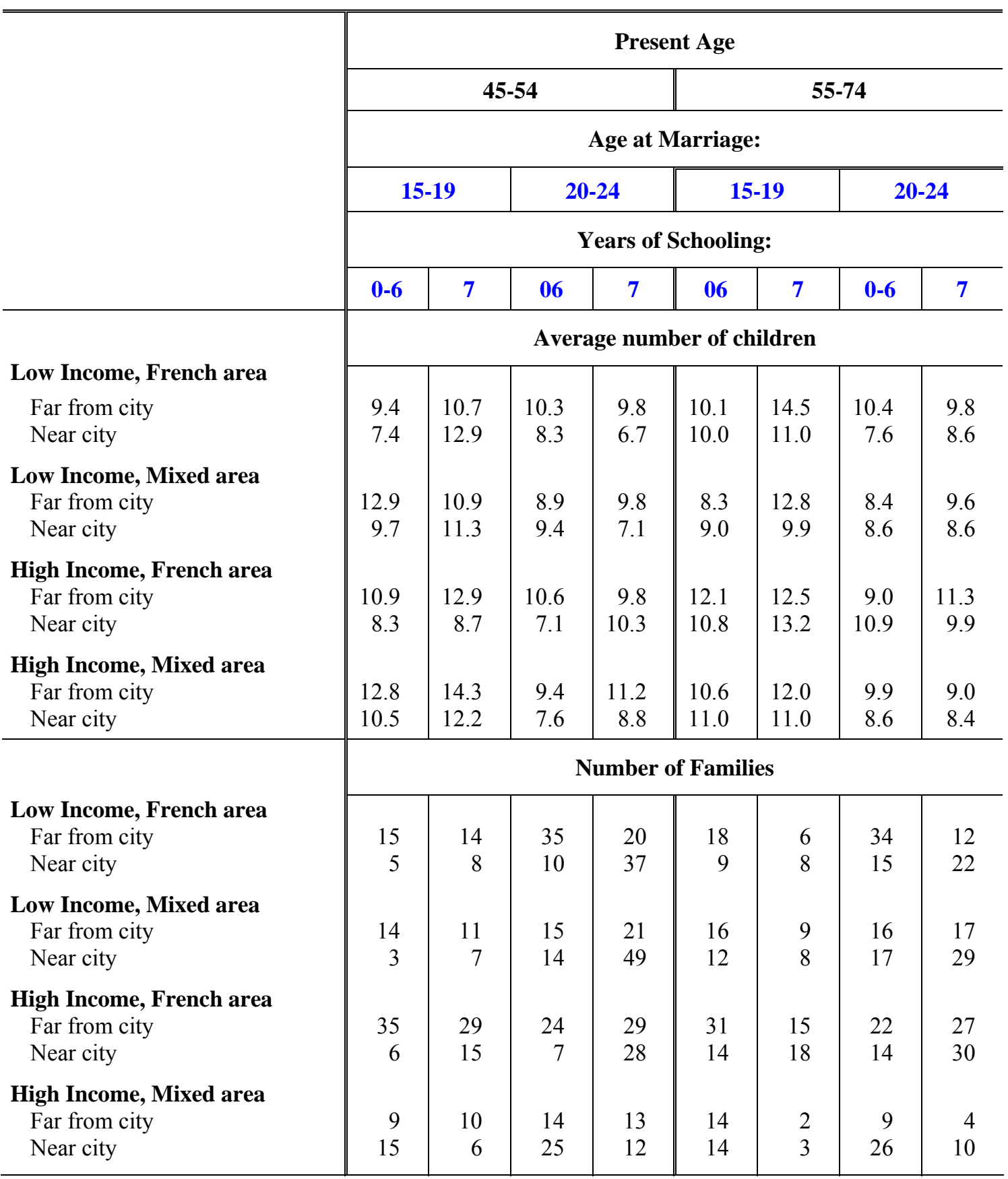


[p. 95]

When the statistical data are examined on this point, and they rather consistently report that, at a moment of time, there is a difference in family size, evidence of the movement is provided. Some social effect appears to flow from cities which influence the number of children born to those living near-by, but no effect flows from English-speaking people to French. Though there is undoubtedly contact between French and English, in business as in social life, the behaviour of the French farmer, in one fundamental matter at least, is not determined by it. The influence of the English-speaking world upon him appears to be via the French cities. 


\title{
COMMENTS
}

\author{
Oswald Hall
}

$\underline{\text { Retour à la table des matières }}$

One of the universal features of industrialization is the fact that industry mobilizes a set of people, who are ignorant of the ways of the urban « work world », and makes them part of the industrial community. In so doing, to use a phrase of E.-C. Hughes, it sorts and sifts them. That is to say, it sorts and sifts them into occupational classes, into social classes, frequently by ethnic background. And it may sort them out spatially as far as their places of residence in the community are concerned. Industry, in mobilizing a work force, is a formidable mixer of diverse peoples but it also sorts and sifts on a grand level.

Mr. Keyfitz is introducing us to some of the ways in which the rural population of Quebec has been affected by industrialization. Each of the four main sections of his lucid paper invites, or indeed provokes, one to ask further questions. My comments are restricted to the second section, wherein he attempts an analysis of the flow of migrants from the farms, and considers their fates in the urban industrial world. His statistics give us a picture of the Quebec farm workers leaving the farm, entering the urban world, where they appear as an increasing or decreasing proportion of various kinds of industrial workers. For example, we have estimates of those who have migrated in the decade 1931-41 and estimates for the proportion of French among various occupations e.g., truck drivers rose from 24 per cent of the total to 30 per cent in this decade.

These skeletal figures, set forth in a manner of precise elegance, raise a host of further questions. We have here indisputable evidence of geographical movement of farm members and similar evidence of changes in the composition of industrial occupations. What has transpired within these two changes ?

First, there has gone on a process of selection. Notwithstanding Mr. Keyfitz' statement to the contrary, we actually know little about how the migrants are selected for the urban jobs. We do have accurate, and indeed artistic, accounts of the way in which the family on the farm selects the son to inherit the farm. Miner and Arensberg have documented this matter in great detail. Every [p. 97] thirty years or so, the farm requires a new family to run it 
and the current family selects a son whose age, temperament, skill, marital condition, and number of children make him the desirable new owner. The process of selection is sharp and clear.

We have knowledge, too, of the way the farm family selects a member for the learned professions, though here the matter gets out of its hands a bit. It may select a son for the priesthood and make sacrifices to pay for his training, but it cannot guarantee that he will be successful in his studies. It may find itself with an unsuccessful candidate on its hands, who has to be fitted into the work world in some second-best fashion.

A different pattern emerges with the girl selected for the convent. This may be a case in which the girl has failed to find a husband, and bit by bit, comes to accept the life of the convent as the appropriate alternative. In a sense, we can say that she is selected to the convent life because she has been rejected in the marriage market. There are probably a great many places in the work world where the jobs are filled by a process of selection by rejection. Anyone who has spent time in a hospital ward has probably realized that the people who make nice nurses also make nice wives at an early age ; other nurses go on to be supervisors.

To a considerable degree, then, the farm family selects the members to migrate by a process of rejection. It would be of interest to know in what ways the ones who leave differ from those who remain on the farms. It would be of equal importance to understand how selection by rejection affects the one who leaves. Miner has given us a vivid picture of the way in which the son, selected to remain on the farm, develops an equable, self-confident personality - in sharp contrast to that of the boys who, in Arensberg's words, know they « have to travel».

When we turn to the industrial experiences of the rural migrants, other questions emerge. Keyfitz informs us that in the wake of such migration the numbers of French truck drivers increased substantially. He doesn't tell us whether any of these truck drivers are recent migrants from the farms. Perhaps none of these truck drivers came directly from the farms, but the farms supplied migrants who entered more lowly occupation, thereby releasing urban dwellers for the jobs as drivers. In other words the occupations of the industrial world comprise a hierarchy [p. 98] ranging from lowly, despised sorts of jobs to ones that bear prestige and are striven for. Furthermore the migrant from the farm enters this hierarchy at a very low level. Thereafter his destiny is bound up with the extent to which he and his children can climb in this hierarchy of jobs and occupations.

It would be unrealistic of course to think of the new migrants as taking over completely a set of jobs at the bottom of the job hierarchy. Rather, they share these jobs with a set of people who are urban in outlook. Part of the drama of the work world consists of the ways in which urban industrial people deal with the greenhorns from the farm. There is no automatic welcome here. The French-speaking farmers in the Eastern Townships are not automatically welcomed by the English farmers there. These self same French-speaking farmers, faced with the invasion of other French-speaking farmers from the hinterland of Quebec, are likely to apply the epithet «black feet» to the 
newcomers. Nor are these merely rural prejudices. The young doctor from the sticks is not welcomed as an immediate equal colleague by his city bred copractitioners. There is a universal process of partial acceptance and partial rejection here which is an inescapable feature of assimilating the farm migrant into the industrial labour force.

I would like to introduce one further notion. I have stressed the fact that all occupational groups are sensitive to the invasion of their ranks by any kind of newcomer - be he of a different race, language, religion, sex, age or education. In our own society, ethnic groups are concerned about their fates, as groups, in their distribution among the various occupations and jobs which comprise the work world. But no group restricts its attention solely to its own fate. If the French-speaking truck drivers increase from 24 to 30 per cent, some groups have declined proportionately. If these jobs have prestige, some group feels its fate threatened by the success of the French-speaking worker in taking over such jobs. Given our multi-cultural industrial world, this phenomenon is inescapable. The achievements of one group are the measure (to some degree) of the failures of another to keep up in this struggle. Seen in this light, the industrial work world represents a drama on a set of stages, so to speak, on which stages diverse ethnic groups are engaged, at the various points in time, in a [p. 99] struggle with other groups for representation in the multitudinous kinds of jobs and occupations which make up the industrial world. There is room on these stages for concern and anxiety, for jubilation and for renunciation, for hostility and for accommodation as these historic groups strive to achieve their varied notions of their collective destinies.

In conclusion, one might say, in the language of Kenneth Burke, that the industrial world represents, for the incoming migrant, a dramatic spectacle. The scene of the drama is the newly industrialized community. The act under way is the upward mobility of workers. The actors on the stage are the various ethnic groupings of the society. The agencies employed are the methods of selection by which workers are chosen for the various jobs and occupations. The end of the action is the fate or destiny of the ethnic groups as historic units. Mr. Keyfitz's paper represents a lucid, elegant and significant design of the stage on which the Quebec industrial spectacle is going on. 
[p. 101]

\title{
CHAPTER V
}

\section{THE CHANGING SOCIAL STRUCTURES}

\author{
Jean-Charles Falardeau
}

$\underline{\text { Retour à la table des matières }}$

Few of the valuable historical and economic studies of French Canadian society describe the main patterns of its culture and the characteristic elements of its structure. Well-intentioned accounts by visiting observers have often suffered from an exotic slant that distorted otherwise penetrating intuitions. The pioneer Canadian sociologist Léon Gérin has left us the only valuable monograph on the rural French Canada of the past ${ }^{1}$; more recently, Horace Miner has systematically analysed a rural community of the present ${ }^{2}$. For the past ten years, almost any one commenting on or writing about contemporary urban and industrial French Canada has made use of Everett-C. Hughes' admirable French Canada in transition ${ }^{3}$ which hits at many essential aspects of our changing society beyond the perspective of the individual town of Cantonville. A certain number of research projects undertaken at the University of Montreal and at Laval during the last decade reflect the first consistent attempt by French-Canadian scholars to study their society, as part of the Canadian whole and as part of the North American continent.

This essay summarizes what is now known, on the basis of such research about the social organization of French Canada ${ }^{4}$. More precisely, it ascertains

L'Habitant de Saint-Justin, in Mémoires de la Société royale du Canada, $2^{\mathrm{e}}$ série, vol. IV, 1898, pp. 139-216 ; also, Le type économique et social des Canadiens, Montréal, Éditions de l'Action canadienne-française, 1937.

2 St. Denis, A French-Canadian Parish, University of Chicago Press, 1939. http://classiques.uqac.ca/contemporains/miner_horace/miner_horace.html

Chicago, The University of Chicago Press, 1941.

4 This chapter is particularly indebted to a research seminar conducted by the Department of Sociology of the Faculty of Social Sciences at Laval University during the second semester of 1951-1952. To the graduate students who participated in the seminar : Fernand 
the extent to which the process of Indus-[p. 102] trialization has been associated with changes in the historically important structures of our society. An investigation of this problem centers around a few general questions: What traditional institutions, if any, have remained untouched? Which have been transformed? Which have been forgotten or utterly discarded? What new structures have been imported or created in anticipation of, and in response to new situations? All that one can hope for at this stage is to clear a path toward a broad vista. Yet, these questions cannot be ignored; answers to them can be found only by examining our society as a whole, as it was and as it is.

Since the data on certain fundamental problems has not even been gathered, we have to rely upon a great number of tentative generalizations. Our task consists more in stating research problems than in presenting a definite picture. Even so, we must distinguish between at least three levels of phenomena that constitute the totality of social life : the ecological structure of the local communities; the division of social labour within the society and the new trends in family life, in parochial organization, in the relationships between the clergy and the urban population and in the patterns of communication between the English and the French ; finally, the many ways in which the traditional symbols and values of our society have been modified and the corresponding motivations, attitudes and outlook that have recently developed among significant groups of the population.

\section{CHANGES IN THE ECOLOGICAL STRUCTURE OF THE COMMUNITIES}

In Quebec as elsewhere, new industries have burst existing communities and have brought new ones into being. Yet, there are still many urban communities, even cities of appreciable size, whose chief function is far from industrial. There are others in which industry and other economic activities are equally important. As Faucher and Lamontagne indicate in their historical essay, typical geographical-industrial complexes have been created at successive stages in our industrial development. The growth of industries, especially since the 20 's, has determined a compartmentation of the province into new economic regions. The most [p. 103] accurate of the recent studies recognize the fifteen areas referred to by Keyfitz and it is the task of the economic geographer to delineate and to describe them more fully. We need only recall here that the types of urban or semi-urban communities vary from region to region and, within regions, according to the type of dominant industries.

Dumont, Gilles Beausoleil, Yves Martin, Gérald Fortin and Luc Lessard, the author expresses his gratitude for their valuable cooperation and suggestions. 


\section{Types of communities :}

Most of the existing schemes of classification of the urban communities of Quebec are based on criteria such as population, juridical status or administrative functions, that have only secondary or indirect significance. A new, meaningful typology is needed and it should be established with regard to the degree of industrialization. Two leading questions should guide the choice of the criteria of classification : 1 . Which was there first, industry or the community? 2. At what period in the history of the province has industry given rise to, or transformed the community? The first question, as will presently be shown, has an important bearing on the ecological structure of the communities. The twofold classification which it suggests lends itself to a cross-classification based on whether industry is single or multiple in the communities. The second question, while referring to the general economic evolution, will help to determine the important criteria for further crossclassifying the communities by types of dominant industries, such as pulp and paper, textile, mining, etc. Whatever the degree of its final refinement, such a classification would ultimately be polarised around three main types of communities: 1. those where one or more industries have exclusive importance ; 2 . those where the importance of industry is shared with other economic activities ; 3 . those where industry is nonexistent.

Professor Everett-C. Hughes was not far from this conception when, in 1936, he proposed the following five-class typology of French-Canadian communities : 1 . the old, settled agricultural parishes ; 2 . the new agricultural and fishing communities ; 3 . the old, small French towns which, of late, have been invaded by industry; 4 . the new frontier-towns where industry came first ; 5. the former English towns where French farmers have moved in as labour. Montreal and Quebec were considered as special [p. 104] cases ${ }^{1}$. More recent research enables us to submit the following scheme which envisages all the Quebec communities as located somewhere along a continuum, one extreme being the single industry, company-town type of community, like Arvida, the other extreme being the non-industrial, administrative or educational center, such as, perhaps, Nicolet or L'Assomption. The classification is as follows :

Bulletin of the Society for Social Research, University of Chicago, June 1936, pp. 1, 2, 8. 
1. Single-industry, company-owned communities

2. Single, dominant industry centers, which are subdivided into:

a) Pulp and paper centers ;

b) Textile communities ;

c) Mining towns ;

d) Hydro-electric and chemical centers ;

3. The mixed, industrial-commercial towns ;

4. The predominantly trading centers ;

5. The non-industrial towns, which may themselves be subdivided into many sub-categories.

Montreal and Quebec are also considered as special cases.

This typology is only tentative, but in our opinion, points in the right direction by assuming that the most telling feature of contemporary communities is the extent to which their existence and social organization depend on industry. It is in the light of this basic factor that comparisons between the population volume, the ecological structure, the occupational and ethnic distribution and the complement of institutions of different categories of communities assume their full meaning.

\section{Ecological structure of urban communities}

The church building marked the center of the territorial pattern of the former French-Canadian rural community or small "provincial» town. Around the church clustered other ecclesiastical, educational and public buildings, while the general stores and the offices of the few local professional men extended from there along one main artery. In medium-sized towns, these features were magnified into more complex combinations which often involved [p.105] some territorial distribution of the local population into areas differentiated by occupational and social status.

In the more recent communities of the frontier areas or of the older regions which have been created by industry, this pattern has been drastically altered. It is now with reference to the factory, the plant or the mining pit that the workers' houses, the service establishments and other community institutions have successively located themselves. The beverage or the gambling house, the grab-bag drug-store and the department store often chronologically preceded the parochial churches or at least competed with them as interest centers. In communities invaded by industry, either the factories were established at the periphery or outside the existing settlement and acted as new poles of human concentration, or they were located within the boundaries and determined a geographical re-distribution of the residential districts and of their service institutions. 
The rural community of former days had not been planned in the modern sense of the word but it had an organic unity of its own. It had esthetic as well as functional interest. Our new urban communities have grown without much planning. Many of them look as though the slum districts of metropolitan cities had been superimposed overnight over large villages. The workers' areas of most of these communities have been built like temporary settlements. Here is, for example, the description which a recent observer gives of them : " One needs only walk through these districts to realize that they look improvised. Dwellings look like camping houses. One would guess that they are provisional, only built to shelter seasonal workers: no planning, no architectural preoccupation... only sad streets edged by ugly-looking houses. $\gg{ }^{1}$ The saddest part of the story is that this type of cheap, distressing architecture has now spread from the periphery of our mushrooming urban communities into the countryside, along the formerly picturesque roads of even the most secluded rural areas of the province. A motor-car trip between Montreal and Quebec, or down the south shore of the Saint Lawrence from Levis, gives one the impression of driving through a perpetual extension of the worst-looking areas of Valleyfield or Drummondville.

[p. 106] From such districts, generally well marked-off from the rest of the community, one passes on to the residential areas of the well-to-do Frenchspeaking middle or bourgeois classes, generally still in the shadow of the mother-church of the community. Then, somewhere beyond, segregated either by parks, by a river or by the company golf course, one discovers the residential area of the English-speaking managers, technicians and often foremen of the industries. Very frequently, the spatial distribution of the French and of the English in our urban communities reproduces their respective position in the industrial hierarchical order. There is, within each city, an English community with its two or three protestant churches, its school, its community center and the like, and a French community subdivided into characteristic areas. On this basic theme, there are indeed many variations. Whatever the variation, the overall impression is that most of our urban communities are beginning to look more and more like any urban community on this continent. As a correspondent from the London Times recently remarked: "The west End of Montreal might be in an American metropolis, the main shopping street of Quebec city in a middle-sized American town... ${ }^{2}$

Gérard PELLETIER, D'un prolétariat spirituel, Esprit, ${ }^{\text {os }}$ 193-194, août-septembre 1952, p. 194.

The Times, London, 20 March 1952, Progress in Quebec : French Canadians' adoption of new industries. 


\section{CHANGES IN SOCIAL ORGANIZATION}

It is within the matrix of such changing communities that French-Canadian society has been gradually transformed, at times with sudden outbreaks, at times at a slow, often unnoticeable tempo. The complete story of this transformation cannot be known before we are in possession of intensive monographs that will fully report what has actually happened in some crucial areas of our social life. The most fundamental of these is the occupational structure. The embedding of industry in any society immediately brings about new life activities for all those whom it calls to its service in one way or another. Changes at the level of occupations are thus the origin of a chain reaction of changes throughout the social order: in the organization of the family ; in the relationships between society and the Church; in the lively [p. 107] area of contact, communication and cooperation between French and English.

\section{Occupational diversification}

The shoe factories of former days; the textile and the pulp and paper mills of the turn of the century and of the early 20 's ; the frontier mining concerns of Abitibi, the heavy metallurgical centers and the hydro-electric and refining centers of more recent date, - all these, as they established themselves at various stages, absorbed growing segments of a working population consisting either of former rural farmers and artisans, or of urban craftsmen, day laborers and inexperienced young adults. The statistical literature on the typical stages of this evolution is well known and Keyfitz' study sums up the tell-tale signs of the present trends. Between 1871 and 1951, about 400,000 rural young men left the farms on which they were born and, whereas the absolute number of people engaged in non-agricultural industry increased by 748,000 , the absolute number of those in agriculture decreased by $17,000 .{ }^{1}$ In 1951 , only 17 per cent of the total gainfully employed population is engaged in agriculture. There are, in the province, approximately 12,000 industrial establishments employing over 400,000 salaried workers who represent one third of the total salaried population of Canada and about 30 per cent of the total Quebec population. ${ }^{2}$

This re-orientation has involved women as well as men. The female industrial hand-worker has been a familiar social type in Quebec for many

See chapter IV, Population problems ; also, chapter II, Recent industrial growth.

Aurèle GAGNON, Étude des occupations de la population canadienne-française de la province de Québec, in Contributions à 1'Étude des sciences de 1'homme, édité par le Centre de recherches en relations humaines, Montréal, ${ }^{\circ}$ 1, pp. 147-160. 
years. Her immediate ancestor is the country girl who, back in the 1860's or 70 's, migrated to the New England states with her family or her husband and settled there as textile weaver. Leather and shoe industries, corset and garment factories have, for over fifty years, made use of women's work in this province and they were followed by the textile mills which attracted a great number of women from the country. World War II intensified this process tremendously. Ammunition factories and expanding wartime industries depopulated the country of thousands of women, [p. 108] married and unmarried, and automatically absorbed the total force of domestic servants. It has been estimated that a total of about 60,000 women in Quebec left the country for the factory between 1941 and 1944 and the data available indicate that very few of them returned to the country after the war ${ }^{1}$. From what we know, the greatest proportion either married workers in the cities or moved along to larger industrial centers, particularly Montreal and even Toronto.

But statistics, elaborate as they may be, reflect only the superficial part of the more deeply interesting story. Many observers, including Miner and Hughes, have suggested that one function of industry in Quebec has been to absorb the constant overflow of farm population at each generation which formerly had to migrate to new colonization areas or outside the province. Most likely, the history of many of these migrants, especially those of an older generation, must have a content and a shape similar to the adventures of the old Euchariste Moisan, the pathetic key character in Ringuet's novel Thirty acres who, after a lifetime on a prosperous Quebec farm, ends up as night watchman in a New England garage. We still have to learn what have been the psychological and sociological consequences of such uprootings. We would also like to know what have been the typical sequences of occupations of individuals and families who had to shift from farm to factory during the last three or four decades. It is fairly well recognized that most French-Canadians entered the industrial market at the lowest level of unskilled work. They had to learn and to master unknown skills on the job, the hard way and the slow way. It was to provide their sons with specialized training that technical schools, arts and crafts schools were eventually founded, although at a relatively recent date. $^{2}$

Becoming an industrial worker meant, for the French-Canadian, not only learning new skills but entering the highly competitive struggle of a new impersonal work world for which his traditional education had not equipped him. It meant moving into a status [p. 109] of occupational subordination to a culturally-alien employer, whether anonymous or individualized. He was used to social relationships of a highly personal and emotional character and felt like a stranger in the bureaucratic, hierarchical social universe of the factory or the plant where most English and Protestant foremen and managers put a premium on technical efficiency and communicated with him in a language he

Madame Henri VAUTELET, Mémoire sur l'orientation du travail féminin d'après-guerre, publié sous les auspices de la Fédération nationale Saint-Jean-Baptiste, Montréal, p. 13 ; Gonzalve POULIN, o.f.m., Orientations nouvelles de la femme canadienne, Culture, vol. V, n, 4, décembre 1944, pp. 403-414.

See chapter VIII, by Léon LORTIE, Le système scolaire. 
did not master. New values as well as new goals of life ambition were imposed upon him. The almost inevitable result was frustration, loss of selfconfidence and a growing consciousness of alienation. These feelings breed occupational instability. Actually, one leitmotiv that recurs obsessingly throughout the greatest number of case histories of French-Canadian workers that have already been gathered ${ }^{1}$ is the litany of the successive occupations held by the family head in the course of his lifetime.

These remarks emphasize certain aspects of what could be called the «French Canadian differential» in the system of division of social labour in Quebec. Within this system, the English perform especially the financial, managerial and technical functions while the French are rather concentrated around the services, clerical, small industry, commercial and professional activities. The latter have striven, for the last thirty years, to ascend the higher rungs of the industrial ladder. The specialized occupations associated with modern technology such as chemistry, civil and mining engineering, physics, have become possible fields of vocational orientation over against law, medicine and priesthood which traditionally constituted the exclusive trilogy of professional ambition. The emergence of these occupations also influenced the re-orientation of university teaching and research. Yet, it seems that the actual achievement of French-Canadians in the new scientific professions remains of a modest order and Professor Hughes pertinently indicates some of the deep cultural reasons that may explain this reluctance. ${ }^{2}$

Among a total of 9,304 students who, between 1939 and 1950, graduated with their B.A. degree from the classical colleges in the province, 3,447 or 37 per cent entered the priesthood. Of the [p. 110] remaining 5,857, 40 per cent chose the medical profession, 16 per cent engineering, 11 per cent law, 8 per cent commerce and only 7 per cent " applied sciences. ${ }^{3}$ A recent monograph on the engineering profession shows that in 1949 the two French universities of Montreal and Quebec produced only 3 per cent of the total 3,300 students graduating as engineers in Canadian universities and that, in 1951, the 1,800 engineers of French origin in Canada constituted only 5.1 per cent of the total number $(35,000)$ of Canadian engineers and about 25 per cent of all the engineers in Quebec. ${ }^{4}$ At a symposium organized in 1947 by the ACFAS on «The position of French-Canadians in scientific careers", our colleague Cyrias Ouellet estimated that about only 5 per cent of the Canadian physicists and mathematicians are French-speaking and that the universities of Montreal and Quebec turn out a total annual production of only ten to fifteen. Six per cent of the memberships of the Canadian Institute of Chemistry are French

\footnotetext{
By the Department of Sociology at Laval.

See chapter X, Regards sur le Québec.

The fact that the students coming out of the classical colleges are still largely attracted by the traditional university Faculties is interestingly confirmed by the remarks of Arthur Tremblay on the present vocational trends among young French-Canadians (in his Commentaires of chapter VIII, infra). The data just reported have been gathered by the monthly review L'Enseignement secondaire and are cited by Huet MASSUE in Premier supplément à l'étude de la contribution de Polytechnique au Génie canadien, Revue trimestrielle canadienne, Montréal, $38^{\mathrm{e}}$ année, numéro spécial, janvier 1952, pp. 47, 49.

Huet MASSUE, op. cit., pp. 7, 14.
} 
and, whereas 15 per cent of the Montreal area chemists are French, the percentage is still lower in such industrial centers as Arvida, Shawinigan and Beloeil. ${ }^{1}$ The French-Canadians' own invasion of the higher technical occupations offered by the invading industries is still a timid and slow process.

\section{The family :}

The daughter of Maria Chapdelaine who was an ammunition-factory worker at Valcartier during the war now lives with her own family of five children in the Rosemont ward of Montreal. Maria's married brothers are employees of the Aluminum Company at Arvida and Shipshaw after having been workers at the Jonquière [p. 111] pulp plant. This fictitious epilogue to Louis Hémon's classic on French-Canadian family life on the frontier corresponds to thousands of actual histories. On the basis of the family cases already referred to, it seems that a great number of French-Canadian families do move geographically to an amazing degree during their lifetime as families. The greatest proportion of them is now three or four generations away from rural experience. Yet, their behaviour reflects a mixture of a strict adhesion to the traditional mores and of impatience to conform to exaggerated forms of emancipation.

Enid Charles' studies have shown that there is a " French-Canadian culture complex » with regard to family and that, if the size of families still remains rather high in more recent urban communities, it tends to decrease in larger cities, and strikingly so in upper-class suburban areas ${ }^{2}$. Keyfitz' study has elaborated these data. In 1950, the discussions at the Laval Department of Industrial Relations Sixth Annual Conference on the «Social security of the workers' family » brought out the extent to which families of French-Canadian industrial workers have shifted away from the spirit of familism and from the internal solidarity that was characteristic of our rural families. The family whose head is a wage-earner, and more particularly, a factory wage-earner, is economically unstable and vulnerable ${ }^{3}$. A survey made in 1945 in Quebec City showed the great fragility of the economic cycle of such families : the per capita income of the family, highest when the family is formed, constantly decreases till it reaches a low point at the time when the head of the family is

Cyrias OUELLET, Mathématiques, physique et chimie, in La situation des Canadiens français dans les carrières scientifiques, Symposium tenu à l'Université de Montréal, le 13 octobre 1947, lors du $\mathrm{XV}^{\mathrm{e}}$ Congrès de l'Association canadienne-française pour l'Avancement des sciences, Document $n^{\circ} 4$ de Pédagogie et d'Orientation, publié par l'École de Pédagogie et d'Orientation de l'Université Laval, Québec, juin 1948, pp. 6-14.

Enid CHARLES, The changing size of the family in Canada, Eighth Census of Canada, 1941, Census monograph No. 1, Ottawa, 1948.

See, in particular, Maurice TREMBLAY, Sécurité de la famille ouvrière : Position du problème et principes de solution, dans Sécurité de la famille ouvrière, Sixième Congrès des Relations industrielles de Laval, Québec, Les Presses Universitaires Laval, 1951, pp. 13-14; see also, Gonzalve POULIN, o.f.m., Problèmes de la famille canadiennefrançaise, published by Le Centre de culture populaire de Laval, Les Presses universitaires Laval, 1952, ch. II, Transformations de la famille canadienne-française. 
between 45 and 49 years of age ; it increases slightly during the next ten years, then decreases again ${ }^{1}$. The material and non-material heritage which the family can give its children is drastically limited. Most [p. 112] families can select only a few of their children for advanced studies in classical colleges. In general, girls have priority over boys at the time of this selection. The other children must remain satisfied with commercial studies or work their way somehow through higher schools. On the other hand, wage-earning children become economically adults as far as their family relationship are concerned. The novels of Roger Lemelin and Gabrielle Roy suggest what this reorientation of relationships between father, mother, and working children, implies in terms of frustrations of the former and emancipation of the latter. Equalitarian and democratic-minded family units have substituted themselves for families of the traditional authoritarian, quasi-patriarcal type.

\section{Relations between clergy and society :}

It is difficult to understand French-Canadian society past and present without reference to the Catholic Church. For it is the clergy which has historically integrated, dominated and controlled our society. It has molded its basic institutions, its traditions, its mentality. Given the importance of the priests in parochial life as well as the initiatives which they were the first to take in the field of education, their autonomy in spiritual matters expanded into a considerable influence on all planes of intellectual, professional, economic and social life. Two essential features of the relationship between the Church and French-Canadian society are not generally given enough attention. First, the French-Canadian clergy has never been recruited from any particular upper-class of society. Its members have always come from all walks of life, mostly from rural and urban middle-class families. Almost every French-speaking family has one of its members or a close relative in the clergy or in the religious orders and congregations. Similarly, any former college student remains bound by the old school tie to an impressive cluster of priests. The clergy is neither above nor beyond but within the community. This, as Lord Durham noted in his famous Report, makes for a strong, personal type of relationship between the people and the priests. The same personal character can be observed in both the informal and the formal relationship between the Church as such and the State, federal or provincial. Although there is no written legal covenant or con-[p. 113] cordat defining the status of the Catholic Church in Quebec, - perhaps because there is no such formal definition, - the relationship between Church and State has always taken for granted the fullest and most intimate co-operation. The actual situation is one of unwritten, global alliance.

Maurice LAMONTAGNE and Jean-C. FALARDEAU, The life cycle of French-Canadian urban families, Canadian Journal of Economics and Political Science, Vol. XIII, No. 2, May 1947, pp. 233-247. 
The spiritual and social functions of the clergy have been historically concentrated in the parish, which is the ultimate, microcosmic, organizational unit of the Church. In rural French Canada, the parish was also the integrating unit of local community life. As Léon Gérin, Miner and others have pointed out, the role of faithful parishioner totally absorbed that of citizen and the whole social life of the rural habitant, till very recently, was completely motivated by his participation in a parochially-defined religious system of action. The clergy still owns or controls, directly or indirectly, teaching institutions at the primary, secondary and university levels. It has organized or sponsored hospitals and social welfare institutions, professional associations, such as the Catholic Syndicates, economic reform movements, such as the Cooperative movement, and adult education.

The way in which urban life as such and more especially the way in which the invasion of hitherto stabilized urban communities by industrial workers transformed the traditional parochial equilibrium are well enough known. Everett-C. Hughes, for example, has described how the former single parish of Cantonville was eventually broken up into three new parochial units. The phenomenon of the social differentiation and ranking of urban parishes according to the socio-economic areas of which they are parts has been described for Quebec City, Montreal and elsewhere ${ }^{1}$. The sophisticated French-Canadian urbanite tends to be parochially an extraterritorial. The attachment which he may feel for $a$ parish church, not necessarily his, is determined by prestige motivation of a secular, not of a religious character. An observer already quoted remarks that « there are no significant bonds between the (urban) faithful and their pastor any more... The rural farmer could, in all confidence, go to see and talk with his pastor and submit his problems to him. The urban worker has to ring at a rectory, on the door of which office hours are posted, and where all he can expect are [p. 114] impersonal relations with the priest who happens to be on duty ... The parish is no longer a centre of life ... The attitude of the workers toward the Church is more and more similar to the attitude which they adopt toward the industrial institutions which employ them ... Like the factory, the parish is now interchangeable. ${ }^{2} \gg$ In other words, the parochial religious universe of the French-Canadian worker is becoming disenchanted. It is already impersonal and bureaucratic.

Further questions remain to be answered if one seeks to evaluate the actual degree of such disenchantment. For example, under what social conditions does the parish as an institution cease to be the main local integrating unit in a Catholic society such as ours? Which social groups and classes are first to dissociate themselves from the parish? To what social sanctions are they submitted, or with what admiration are they viewed by others? What other forms of religious behavior do they adopt and to what extent do they remain in actual contact with the larger Church ? Actually, the Church, in Quebec, as in other countries, has been aware of this spiritual alienation of urban masses in our time and, for the past thirty years or so, has been active in developing new

Jean-C. FALARDEAU, The parish as an institutional type, Canadian Journal of Economics and Political Science, Vol. XV, No. 3, August 1949, pp. 353-367.

Gérard PELLETIER, op. cit., pp. 195-196. 
institutional systems of apostolic action. One thinks, in particular, of the modern Catholic Action movement, the philosophy of which is that the Church, over-looking the parochial framework, must reach the members of professional groups and socio-economic classes. Hence, the emergence of numerous age, sex and occupational associations such as the Jeunesse ouvrière catholique, the Jeunesse étudiante catholique, and the like. These movements flourished in Quebec chiefly between the thirties and the Second World War, but close observers point out that the successful formula for attracting young workers has still to be found.

The most fascinating development has been that of the Canadian and Catholic Confederation of Labour, more popularly known as the Catholic Syndicates ${ }^{1}$. Far from all French-Canadian workers are unionized, nor do all those who are union members belong to the Catholic Syndicates, although nearly all the Syndicate [p. 115] members are Catholic and French-speaking. There is no information about the union affiliation of the Quebec Frenchspeaking workers in particular. Nonetheless, a thumb-nail sketch of the total organized labour force in the province provides a useful frame of reference. In 1953, out of an estimated total of 265,000 union members in Quebec, more than 100,000 were claimed by the Canadian and Catholic Confederation of Labour, about 115,000 by the Canadian Trades and Labour Congress, and 50,000 by the Canadian Congress of Labour.

The history of Catholic unionism in Quebec has been written only in part. What we know tells of a meritorious effort to create, within the existing social order, institutions specifically intended to meet the needs of the FrenchCanadian industrial workers ${ }^{2}$. The development shows three distinctive stages : from 1900 to 1921, the first phase of gestation, stimulated by Churchinspired study groups in Montreal and Quebec from 1921 to about 1943, the second phase of integration and "promising realizations "; finally, the contemporary re-orientation of the movement. Formally established in 1921 under the stimulus and sponsorship of the Church, the Catholic Labour Confederation has been typically a Quebec movement. Through the intermediary of unit chaplains who where the representatives of the Church, leadership came from above and the ideology of the Syndicates remained for a long time static and paternalistic. The Syndicates developed a paradoxical complex of submissiveness to employers and xenophobia against «alien » management as well as against «alien» viz. non-French and non-Catholic workers. Most often, the Catholic Syndicates were close equivalents of company unions. Whenever an important conflict arose between a company and a syndicate, the informal pattern of reaching a solution, notwithstanding the formal procedure stated by the written law, involved personal negotiations

See chapter VI, L'Évolution juridique by Jacques PERRAULT, and the Rev. Jacques COUSINEAU'S Commentaires on chapter IX.

See, Gérard TREMBLAY, Le syndicalisme catholique à Montréal, in L'Organisation ouvrière catholique au Canada, Montréal, L'École sociale populaire, pamphlet no. 105, 1922 ; H. A. LOGAN, Trade Unions in Canada, Toronto, The Macmillan Company, 1948, ch. XXIV-XXV; Jean-Pierre DESPRÉS, Le mouvement ouvrier canadien, Montréal, Éditions Fides, 1946, ch. II. 
between the representatives of the Church, management and government. Of late, the Catholic labour movement has found from within its ranks [p. 116] militant lay leaders inspired by a mature rationale ${ }^{1}$. In our opinion, the significant rite de passage of the Catholic Syndicates to adulthood and maturity happened a few years ago, at the time of the famous Asbestos strike. For the first time, the tradition of tripartite discussions was broken. The Syndicates decided to speak for themselves. They also took upon themselves to state what was the issue in this particular labour conflict. Organized Catholic labour actually fought for and obtained the recognition of a new status. From then on, it would be an equal partner with Church, State and Industry. The feeling of solidarity between all the labour organizations in the province was considerably reinforced. It was the end of an era, perhaps the most important date in the social history of Quebec's twentieth century. ${ }^{2}$

\section{Class structure :}

One irreversible transformation of contemporary Quebec has been the creation of a French-Canadian urban demo. Long before this demo became noticeable, the structure of social classes had been changing. In order to realize it, we can refer to the homogeneous and relatively classless rural communities of the type described by Miner. There, far below the small group consisting of the curé and a few persons of high political and ancestral prestige, most families and individuals enjoyed an identical status associated with the ownership of equally-valued lands. We may also refer to the class system of the whole French-Canadian society as it appeared at the turn of the century. As in many minority societies, the criteria of social prestige were those connected with a high degree of education and with any expression of achievement of a moral, intellectual or political order. At the highest level of society were the clergy who enjoyed the prestige associated with the Church. The next highest stratum was that of the professional men, the politicians and other public figures and those recognized as intellectuals of one variety or another. At a rela-[p. 117] tively lower level were the merchants and businessmen who constituted the mobile upper segment of an otherwise illdefined French-Canadian middle-class, from whose lower ranks the workers were gradually marking themselves out as a socially identified group.

This class system has expanded in many directions. In fact, there is hardly one system now but a congeries of contrasting local systems. These vary from area to area, depending on the volume and heterogeneity of industry, the degree of occupational diversification, the intensity of urbanization and the

See Jean MARCHAND, Quelques aspects idéologiques des relations ouvrières patronales paper given at the twenty-fifth annual meeting of the Canadian Political Science Association, University of Western Ontario, June 3-5, 1953 published in Hermes, vol. III, No. 9, Quebec, Fall 1953.

2 An overall study of the Asbestos strike is now in preparation by a group of jurists, economists and labour specialists. It will be published shortly under the auspices of the Canadian research foundation known as Recherches Sociales. 
pattern of ethnic relations in each area. Proximity to Montreal is also an important factor. Consequently, until more research is done, one must remain satisfied with describing the class structure of a few communities which have been recently investigated because they were tentatively considered as typical.

The first is a community which was a prosperous pulp town in the 20's and which now lies at the periphery of the Chicoutimi-Arvida conurbation. Amazingly enough, its class structure, with one variation, appears to reproduce the traditional pattern in which one finds, in a descending order : the clergy, the professional men, the merchants and the working population of commuters to Arvida. The case of Chicoutimi itself is of a new character. There, the "big merchants " are on the same social level as the professional class, whereas a sensitive upper-middle class of bank managers and insurance executives struggles to be socially dissociated from the large core of an illdefined bourgeois-like, highly sophisticated mass of clerical, highly-skilled and even semi-skilled workers. Two areas of the town are solidly of workingclass status.

A blossoming light-industry town, north of Montreal, exhibits similar features. Prior to World War II, the class structure of this town showed a neat dichotomy between the professional class, managers of industry and tradesmen on the one hand, and workers on the other. In contrast, the post-war structure reveals vivid class distinctions, in the following descending order : managers of industry and professional men, merchants and civil servants, white-collar workers, foremen and workers. Finally, the class structure of an Eastern township mining community reflects the uncertainty of the population, first, concerning the relative prestige of the local politicians and of the English managers of the in-[p. 118] dustries, then, concerning the relative prestige of professional men and big merchants. The significant criterion for distinguishing between the two main social categories is the distinction between the occupations salissantes and the occupations non salissantes, the latter being associated with an assumed high degree of education.

From these and other recent observations in Quebec and Montreal a few provisional generalizations can be suggested. First, it seems that at the upper level of our society, the hitherto untouched prestige of the old professions is now transferred to other occupations and social activities as a criterion of social ranking. Recently imported professions, such as architecture, engineering, chemistry, have become as highly-valued as medicine and law. Economic professions such as bank and corporation management, investment banking, factory ownership, and the like, are also enjoying almost the same social prestige as the older professions. More precisely, these professions are now looked upon by young men and their fathers as life goals as worthy as the older ones. Secondly, the farmers, except in the poorer or frontier resettlement areas, are now thinning out into a residual, well-to-do and businesslike social category. The most universally felt social cleavage is that between white-collar workers, as a whole, and industrial and unskilled workers, as a whole. Workers are themselves sensitive to imperious class distinctions within their social universe, on the basis of : a) skill ; b) closeness to management; and, $c$ ) the proved ability to provide one's children with advanced education. It 
goes without saying that labour unions have been potent in determining and emphasizing class-consciousness among workers.

An acute feeling of social distance and social discrimination does now exist between these two levels of our society and it is checked only by the feeling of moral and social superiority shared by the thousands of families of all classes who have members in the clergy. Then, notwithstanding this new cleavage, one finds, especially in urban communities of recent development as well as in large French-speaking areas of Montreal, a great uncertainty about the precise level of one's rank. If French-Canadians were, in the past, reputedly less socially ambitious and mobile than the rest of North America, they are now at the other extreme, in a state close to social nervousness.

[p. 119]

In many of the larger communities, the behaviour of French-Canadian middle-class families can be characterized as that of erratic nouveaux riches. Indeed, it seems that we now have two overlapping scales of social stratification, each oriented toward a set of values which is in conflict with the other. One of the scales perpetuates the traditional ideal. It recognizes the clergy as the supreme social group and gives priority to spiritual and intellectual achievement. The other also takes the clergy for granted but it is closer to the secular, economic scales of prestige prevalent in the remainder of the North-American "money society. » If one wanted a fruitful general research hypothesis, it could be suggested that two main significant criteria of class rank in Quebec today are a) identification with, and closeness to the ecclesiastical power $b$ ) and identification with and closeness to the political power ${ }^{1}$.

We must not overlook a third important criterion of status evaluation. It is closeness to, and identification with the English. Wealth, and the social success of which it is evidence, have often had an "English» and «Protestant» connotation in Quebec. More exactly, economic success has been evidence of an ability to master skills and dominate institutions which were historically the almost exclusive privilege of the dominant ethnic group. Economic success is the ambivalent sign of a revenge and of close professional or social association with the English, since money can be made only out of institutions or activities originally controlled by the English. Actually, it must be realized that Everett Hughes' statement, quoted by Keyfitz, must now be supplemented with the remark that French-Canadians have the rewarding feeling of being now more and more active, and not only passive, as in the past, in the industrial process. They are now found in somewhat increasing numbers among the owners and managers of great industries, and correspondingly, they have less of an inferiority complex towards the English.

Attitude towards the English have also changed considerably because of more numerous and closer contacts not only among colleagues within the

Jean-C. FALARDEAU, Refixions sur nos classes sociales, Nouvelle Revue Canadienne, vol. $1, \mathrm{n}^{\circ} 3$, juin-juillet 1951, pp. 1-9. 
industrial hierarchy, but through membership in scores of professional or service associations. The history of the development of French-English relations in Quebec will, to a great [p. 120] extent, have to be the history of the social clubs and of the professional associations. I suppose one could justly remark that Quebec, having fabricated its Middletowns, is now producing its own Babbits. Yet, if industry accounts chiefly for the blossoming of these types of associations, an inevitable by-product of urban life has been the multiplication of groupings of all sorts in which urban newcomers or emancipated workers seem to have found interests and social rewards which they could no longer obtain from parochial or other traditional institutions. This becomes more manifest when one observes the changes in the attitudes of our population.

\section{CHANGES IN VALUES AND ATTITUDES}

The foregoing sketchy analysis suggests the direction towards which and the extent to which the way of life of the French-Canadians has been modified. Actually, they are in the process of painfully improvising a whole urban culture of their own. The Industrial Revolution in Quebec abruptly disturbed a pastoral symphony. New themes and new leitmotivs were brought in which did not have meaning for the local culture. This clerical-rural culture could not adequately prepare the people to meet the expectations and the demands of industrial urban life. When they came to the factories, they found embryonic communities or no community at all, and no existing urban culture into which they could integrate themselves. Or rather, they found institutions and expectations of behaviour that were dominated by the values of the past. They reacted as though they had become estranged or entrapped. We have noted that many groups and many classes still act according to a trial-and-error pattern, undetermined between conflicting norms. On the whole, it would seem that the new worldly ambition of French-Canadian workers and middleclass deviants remains tempered by a deep-rooted drive for stability and security. The career-line of the Quebec industrial or clerical white-collar worker is chiefly determined by a quest for security and involves expectations of occupational advancement through personal relationships. In contrast with this, the familiar North American glamorous symbols of male and female success as well as the myths and standards of the social gospel according to [p. 121] Hollywood are becoming ingrained in our mores. The dreams of the younger and the frustrations of the older are patterned through the channels of escapism created by the North American culture.

Organized labour and particularly the Catholic Syndicates have offered to the workers a broad and politically coherent outlook. They have developed a sense of identification with workers of the whole country, the satisfaction of cooperating within the framework of national and international associations, and a new definition of their ambitions in terms of socio-economic interests, welfare programs and political responsibility. The greater sophistication of the 
urban bourgeoisie and of the sponge-like upper middle-classes is also apparent in the fact that these classes are providing fewer recruits for the clergy. Since most of the recruits for the clergy and the orders now come from families with a working-class background and fresh urban experience, it may very well be that the way in which this new type of clergy will define the goals and the needs of the French-Canadian society will, for the coming years, share the uncertainty now typical of our lower classes. Our clergy seems less sure of the pertinence of certain of its ancient forms of action within the community. As it has been strangely unaware of clericalism in the past, it also seems hardly aware of recurring subtle or striking forms of anti-clericalism. The continuance of its traditional authority, still formally acknowledged, may depend on its ability to formulate with clarity a liberal, long-range labour policy and on its ability to re-orient the pattern of its relationships with larger segments of the population who have developed a stronger sense of responsibility.

As a last indication of the self-destructive character of some of these cultural and spiritual changes in Quebec, a brief reference must be made to the way in which intellectuals state the problem. One of them recently submitted that the main element of our intellectual drama is that our writers are either embarrassed, unable or not free to express the true nature of our social situation. ${ }^{1}$ With Ringuet's novel, Thirty acres, our literature reached the sociological level and came to the end of a long era focussed on country life. With Gabrielle Roy and Roger Lemelin, this sociological interest is, for the first time, focussed on urban life. Almost [p. 122] all our essayists and writers seemingly rejoice in moral, philosophical or facile psychological topics. It is further suggested that they are escapists who, while pretending to embark upon introspection, actually talk about something else. They are blocked by social pressures and sanctions which prevent the free expression of the real problems.

For these reasons, it may be that the first really great writer of French Canada will have to be someone of the caliber and type of James Joyce. Our social milieu is quite similar to the Dublin society where Stephen Dedalus had to forge the esthetic instrument of a total definition of himself and ... to accept the inevitability of exile. When our James Joyce will reveal himself and what will happen to him is anybody's guess. Let us hope that when a FrenchCanadian Leopold Bloom is presented to us, we shall recognize him as a not too disintegrated man in a not too disorganized world.

Jean-C. FALARDFAU

Maurice BLAIN, Sur la liberté de l'esprit, Esprit, n- 193-194, août-septembre 1952, pp. 201-213. 
[p. 123]

\title{
COMMENTS
}

\author{
Aileen D. Ross
}

$\underline{\text { Retour à la table des matières }}$

Professor Falardeau has presented a comprehensive analysis of the effects of industrialization on the people of Quebec. He has had comparative studies of the effect of industrialization on social behaviour in other societies at his disposal to aid him in this monumental task, but very little material from actual studies of the Quebec scene. This latter consideration emphasizes not only the importance of his work, but the skill with which he has drawn together many separate studies and scattered ideas. In fact, his analysis is so impressive that the remarks I have to make will be concerned with sins of omission, rather than sins of commission.

One of the serious omissions, in my opinion, is that there is no reference to the rise of different types of informally organized groups during this change in the basic economic structure of the province. Sociologists have found that groups such as cliques are a universal phenomenon of industrialization. They are now considered to be so important for the participants that it is felt that they enable us to understand much behaviour that was formerly ignored as being « irrational » by the man in the street. For example, the conviction in our society that economic gain is the chief incentive to work has closed the eyes of many business men and social scientists concerned with " rational activity » to the importance of the opinion of the informal group in shaping man's motivations. Thus it cannot be too strongly stressed that the essence of the change in man's attitudes and actions cannot be understood without taking these groups into consideration.

It could perhaps even be maintained that the rise of informal groupings could be used as indices of fundamental change in social structure in a more telling and instructive way than changes in formal organizations. In this respect, it would be important to take into consideration the effect not only of work-cliques, but of many other types including even such phenomena as the rise of the French-Canadian equivalent of the « bobby-soxer ».

Another very important point which Professor Falardeau has not emphasized, although it is brought out in many essays of this book, is that the 
industrialization of Quebec cannot be understood [p. 124] in isolation, but must take into account a larger Canadian picture. For there are many indirect social effects of the impact of English Canada on French Canada which are pertinent to the final analysis of social change which has been summed up under the term of industrialization. In this context, Professor Everett-C. Hughes has repeatedly pointed out that many studies of minority groups are ineffective in that they are concerned only with the minority group point of view, and fail to take into account the effect of the minority group on the dominant group. For example, it was quite evident in my own research of the English reaction to the steady movement of French population into the Eastern Townships that, in such areas, the English Canadians feel themselves to be the minority, and display attitudes and behaviour similar to French Canadians confronted by English-Canadian economic competition and encroachment elsewhere. Thus the relationships between French and English are quite different in the Eastern Townships from those in other areas of Quebec where the English consider themselves to be the dominant group. And the impact of one group on the other is correspondingly different.

This means that a study of the adjustment of either one group to changing condition must always take the other group into consideration within a much more flexible framework of thought than is usual when one group is assigned a position of complete dominance and the other complete minority status. 
[p. 125]

\title{
CHAPITRE VI \\ L'ÉVOLUTION JURIDIQUE
}

\author{
Jacques Perreault
}

$\underline{\text { Retour à la table des matières }}$

Une relation, même succincte, de la genèse et des développements des principaux mouvements sociaux dont l'existence a été directement ou indirectement provoquée par l'industrialisation de notre province depuis trente ou cinquante ans exigerait, pour être au point, l'exposé de toute l'histoire sociale contemporaine du Canada français. Ce tableau enchevêtré nous présente, au point de départ, les Chevaliers du Travail et les Caisses populaires Desjardins, et, au stade actuel, le coopératisme et le syndicalisme catholique adulte, stabilisé, progressif. Entre ces deux moments, que d'efforts, de succès ou d'échecs qui nous disent, sur le plan économique, professionnel, politique ou même religieux, l'ambition qu'ont eue des porte-parole spontanés ou des chefs acceptés de répondre aux besoins nouveaux de notre société ! Que l'on songe seulement à des entreprises aussi diverses que les programmes de colonisation et de "retour à la terre ", l'organisation professionnelle des agriculteurs, l'emprise régionale de partis politiques marginaux tels que le Crédit social, l'histoire de la J.O.C. et la création des Services sociaux.

Ces innombrables croisades et mouvements manifestent des préoccupations inédites, des réponses patientes ou improvisées à des situations sociales inattendues, bref, une société qui fait éclater les cadres traditionnels qui l'étouffent.

D'autre part, en réponse aux relations sociales nouvelles créées par la venue des entreprises industrielles dans notre milieu, apparaît tout un système juridique de caractère nouveau. Un droit nouveau se constitue, avec un inévitable retard sur les événements, et reflète à sa façon l'évolution de nos structures sociales et économiques, nos conceptions de l'ordre politique et juridique. Ce sont ces transformations juridiques que je veux tenter d'expliquer. 
Mon dessein est d'indiquer, dans une perspective très générale, comment la pression graduelle ou violente de l'industrialisation a [p. 126] fait éclater les anciens cadres juridiques de notre société; comment sont devenues sans valeur pratique des règles juridiques qui furent élaborées au XVIII ${ }^{\mathrm{e}}$ et au XIX ${ }^{\mathrm{e}}$ siècles, que nous retrouvons encore dans nos textes de loi, mais qui ne peuvent plus servir à régir l'activité d'une société industrielle ni à résoudre les conflits qui surgissent entre les groupes qui participent à notre vie économique. J'essaierai, en faisant état de quelques cas concrets, d'illustrer comment cette évolution juridique s'est accomplie depuis trente ou cinquante ans et se continue encore sous nos yeux.

Évoquons d'abord les principaux secteurs de notre vie sociale où l'industrialisation a déterminé de nouvelles relations entre les citoyens. Jusqu'aux environs du deuxième tiers du $\mathrm{XIX}^{\mathrm{e}}$ siècle, l'organisation économique et sociale du Québec de langue française était caractérisée par une prédominance de l'agriculture et de l'artisanat. Le commerce dans son ensemble, jusque vers 1880 ou 1890, était l'apanage d'une «aristocratie » étrangère au milieu canadien-français. L'individualisme était une nécessité encore plus qu'une qualité. Chacun travaillait pour soi et les relations entre concitoyens se réduisaient à un minimum. Les règles juridiques relativement simples du droit civil pouvaient suffire à régir l'activité humaine. Les conflits qui surgissaient entre voisins se réglaient assez aisément par l'application des règles traditionnelles de notre droit.

L'industrialisation a changé ce régime. Les relations entre citoyens, que l'on considérait autrefois uniquement civiles et de droit privé, sont devenues des relations collectives, commerciales ou industrielles: relations entre ouvriers et patrons; relations entre cultivateurs qui, par leurs coopératives, font un commerce de l'exploitation du sol; relations entre commerçants et consommateurs; relations anonymes entre individus que la vie économique met en contact par l'intermédiaire d'innombrables institutions.

D'une telle complication est née la nécessité, pour le gouvernement, d'intervenir sans cesse dans le domaine administratif et dans le domaine de la législation. Ce n'est pas la complexité de notre droit administratif qui a causé la complexité de nos structures économiques et fiscales. Au contraire, c'est la participation de tous à la vie économique résultant de l'industrialisation, de la commercialisation et de la collectivisation des occupations de notre popu-[p. 127] lation, qui a rendu inévitable la multiplication de nos lois administratives et fiscales.

Quelques remarques sur l'évolution du droit en général aideront mieux à saisir ce qui s'est passé dans notre province en particulier. On peut poser, comme axiome élémentaire, que le droit est un élément statique des activités sociales, économiques et politiques. Par essence, le droit est conservateur et tend à stabiliser les structures d'une société. Quoi que l'on ait pu écrire à son sujet, il ne peut pas exister de droit révolutionnaire. L'ensemble des lois positives d'un pays, à un moment donné, ne constitue jamais un droit véritablement «progressif». Ce que l'on constate dans la plupart des pays occidentaux à l'époque moderne, c'est, d'une part, un droit composé en grande partie de règles juridiques publiques ou privées, édictées par l'État, élaborées 
depuis longtemps, claires, nettes et précises, admises par la majorité des citoyens. C'est, d'autre part, hors des cadres de ce droit bien déterminé, rigide, traditionnel, l'existence, à des degrés divers, d'un droit en formation, d'un droit qui se crée ou qui essaie de se créer pour résoudre de nouveaux problèmes politiques, économiques ou sociaux. Mais ce droit en formation est, en règle générale, réclamé par une minorité de non-conformistes, par une population en butte à des problèmes nouveaux. C'est un droit discuté.

Ce droit en formation est un droit imparfait et informe. Les problèmes nouveaux qui se posent ne sont pas encore résolus. Il est impossible de trouver la règle de droit parfaite pour résoudre un problème politique, économique ou social qui vient de se présenter subitement et qui bouleverse les situations familières tout autant que les notions traditionnelles. Des modifications juridiques sont demandées par ceux qui veulent obtenir leur place au soleil, mais ce droit nouveau est combattu par tous ceux à qui les changements politiques, économiques ou sociaux menacent de ravir des privilèges ou des intérêts acquis. Les «privilégiés » s'attachent au droit traditionnel, sauvegarde de leurs intérêts, et combattent âprement aussi bien les réformes sociales, économiques et politiques que les lois nouvelles qu'exigent les transformations de la société. Ce droit en formation ne trouve aucun appui auprès de la masse d'indifférents qui, par habitude ou pour d'autres raisons, trouvent plus simple d'être conformistes et de n'accepter que l'ancien corps de droit, depuis longtemps établi et qui fait loi dans le pays.

[p. 128]

En conséquence, non seulement le droit va-t-il généralement être en retard sur l'évolution sociale, puisque la solution d'un problème ne peut être recherchée que lorsque ceux qu'il touche sont conscients de ce problème et de l'urgence d'une solution, mais sa croissance sera encore retardée, soit par des oppositions systématiques ou violentes, soit par l'indifférence de la majorité de la population.

Le droit ne se trouve pas formulé d'avance dans quelques principes généraux. Il est édicté par le législateur et sa formulation, sous la pression de forces économiques ou sous la pression de l'opinion publique, se fait de façon indirecte, imparfaite, hésitante, par tâtonnements. Le résultat est que même ceux qui veulent une modification dans les lois n'ont pas vraiment conscience de la loi dont ils ressentent la nécessité. Ce n'est qu'en cherchant dans l'ombre que l'on va finir, après bien des années et parfois des siècles, par découvrir la règle juridique qui convient au problème qu'il s'agissait de résoudre. Mais déjà ce problème est dépassé et de nouveaux problèmes obligent le droit à se renouveler.

De quelle façon ces problèmes se sont-ils présentés au Canada français ? Notre droit civil de 1867 s'inspire du droit français des $\mathrm{XVII}^{\mathrm{e}}$, et $\mathrm{XVIII}^{\mathrm{e}}$ siècles, garantie des droits de la bourgeoisie et des propriétaires ruraux de France qui avaient été arrachés à la féodalité et à l'aristocratie. Stabilisé et codifié au début du XIXe siècle ce droit est essentiellement un droit de l'individu, du contrat, de l'obligation contractuelle. Il est la résultante d'une lutte qui a duré pendant près de trois siècles, du XVI siècle à la Révolution française, entre, d'une part, les bourgeois et les propriétaires ruraux qui 
voulaient une réforme d'ordre fiscal et politique, et, d'autre part, les féodaux et la monarchie qui jouissaient de privilèges établis depuis le Moyen-Âge, privilèges depuis longtemps sans justification ni raison.

Ce droit, avec les modifications qu'il a connues jusqu'en 1866, était adapté à la vie canadienne-française des débuts du $\mathrm{XIX}^{\mathrm{e}}$, siècle. Mais, en 1890 commença une ère nouvelle. Notre droit civil devint rapidement insuffisant parce qu'il n'apportait pas la solution exigée par l'industrialisation. Ainsi, à titre d'exemple, encore aujourd'hui, on ne trouve, dans notre code civil (aux articles 1666 et suivants), que cinq articles régissant les relations entre employeurs et employés. Ces dispositions étaient-elles adéquates en 1866 ? Elles sont [p. 129] archaïques en 1953. La même remarque, à mon avis, s'applique au droit constitutionnel. Si nous évoquons les débuts de l'industrialisation de notre province, vers 1890, nous constatons que le droit constitutionnel qui établissait alors les normes d'équilibre entre le pouvoir fédéral et les pouvoirs provinciaux avait été promulgué en 1867, à une époque où l'industrialisation du pays n'était pas vraiment commencée. Et, nous n'avons pas encore pu, ou nous n'avons pas su nous débarrasser, en 1953, de cette Constitution de 1867 qui n'a pas été faite (que l'on soit centralisateur ou autonomiste) pour une société industrielle comme la nôtre. Il en est de même en droit pénal ou criminel : les textes qui peuvent avoir trait aux problèmes industriels sont tout à fait récents et notre droit pénal, tel que codifié en 1892, ne tient aucun compte de l'évolution sociale déterminée par l'ère industrielle.

Pour illustrer le fait que notre droit est facteur de retardement, je voudrais noter un phénomène qui fut en quelque sorte l'axe de notre évolution juridique dans le domaine des relations du travail depuis une cinquantaine d'années.

Les conflits d'intérêts dans une société telle que la nôtre en 1850 sont essentiellement des conflits individuels. Dans toute fabrique ou dans tout atelier, les employés sont peu nombreux. L'employeur a sur eux un contrôle direct, autoritaire, dur ou débonnaire. Les relations sont individuelles et les conflits d'intérêt sont individuels. Si, d'occasion, quelqu'un est lésé par son voisin, il n'y a qu'un conflit d'intérêt purement individuel. Un tel conflit va se résoudre automatiquement en un conflit de droits. Encore aujourd'hui, en droit privé, la victime d'un chauffeur d'automobile ne songe pas à utiliser la force pour se faire payer l'indemnité qui lui est due. Sa famille ne pensera pas, non plus, à partir en guerre contre la famille de l'auteur du dommage pour l'obliger à payer l'indemnité qui peut être due. Spontanément, on se demande : « qui est responsable d'après le droit?» $\mathrm{Si}$ on ne peut s'entendre à l'amiable, on a recours aux tribunaux de droit commun qui décident du cas d'après les règles de droit civil et de procédure.

Mais, alors que toute notre législation et toute notre organisation judiciaire se sont lentement organisées puis stabilisées autour de ces conflits individuels, est apparu, avec la multiplication des industries, le conflit collectif. Supposons qu'il s'agissait, vers 1890, d'établir, par exemple, une fabrique de locomotives. Il [p. 130] fallait s'adresser à une collectivité d'épargnants pour constituer un capital économique, collectif et anonyme. Une gérance collective construisait l'outillage économique, - usine, machinerie, etc. -, et l'on devait enfin s'adresser à une collectivité de travailleurs. Il en fallait 500, 1,000 ou 10,000 
que l'on faisait entrer dans l'usine. Le travail était collectif avant même qu'on en ait eu conscience. L'épargne agissait collectivement, par l'intermédiaire de ses gérants, pour exploiter le capital économique, et les ouvriers travaillaient collectivement pour produire.

Mais une telle situation, de soi, engendre un conflit d'intérêts au sujet du produit de l'industrie. Les épargnants qui ont fait des placements veulent avoir suffisamment de revenus pour déprécier et pour renouveler leur capital économique. Ils veulent faire des réserves pour de nouveaux placements, de nouveaux développements industriels. Ils espèrent aussi avoir un surplus que l'on appelle " profit ». L'ouvrier, de son côté, désire une part de plus en plus grande du profit de l'industrie sous forme de salaire. Lorsqu'il a obtenu un salaire minimum, il veut obtenir une part de plus en plus grande du profit de l'industrie pour améliorer son statut dans un monde où, sans qu'il soit luimême à blâmer, le standard de vie s'est élevé. Donc, conflits d'intérêts, mais conflits collectifs que les cadres juridiques traditionnels ne peuvent aucunement résoudre. Avant que d'autres cadres juridiques soient créés par des lois nouvelles pour résoudre ces conflits collectifs, il faut d'abord faire éclater, en quelque sorte, les règles anciennes.

Or, historiquement, cet éclatement fut long et pénible. Il se manifesta en particulier sous la forme de grèves qui devinrent, à partir du dernier tiers du $\mathrm{XIX}^{\mathrm{e}}$ siècle, un élément inévitable de la vie économique nord-américaine. Ce phénomène n'est pas particulier à la province de Québec : on le retrouve dans tous les pays modernes. Il acquit cependant ici un caractère plus complexe.

La différence dans le degré de notre évolution juridique tient aussi à la date récente de notre industrialisation. Il y a, chez-nous, quatre facteurs qui, au point de vue juridique, ont aggravé la situation. En premier lieu, les Canadiens français, minorité culturelle et ethnique, se sont attachés à leur droit français du début du XIX ${ }^{\mathrm{e}}$ siècle comme à une institution essentielle à leur survie. C'est un sentiment répandu dans toutes les classes moyennes et chez la majorité des avocats que toutes les innovations [p 131] juridiques, même celles que rendent nécessaires les circonstances économiques et sociales actuelles, apportées à notre ensemble de lois françaises, auront pour effet d'introduire chez-nous des principes juridiques inspirés du droit anglo-saxon ou américain, incompatibles avec le droit français et devant entraîner la disparition de ce dernier.

En second lieu, l'industrialisation du Québec s'est produite beaucoup plus tard que celle des autres provinces industrielles du Canada et des États-Unis. $\mathrm{Au}$ lieu de s'amorcer progressivement, elle nous a été imposée, en quelque sorte, d'un seul coup, par les industriels britanniques et américains. Il n'y a pas eu de période d'adaptation sociale et économique au cours de laquelle nous aurions pu essayer de formuler de nouvelles lois. Nous nous sommes réveillés avec des industries installées chez-nous par des capitaux britanniques et américains alors que l'organisme législatif et judiciaire n'avait pas eu le temps de s'adapter à cette nouvelle condition.

Un troisième facteur, dont l'effet sur le plan juridique ne fut qu'indirect mais qui constitua un véritable désastre pour la collectivité canadiennefrançaise fut l'émigration massive vers les États-Unis, en particulier de 1850 à 1925. Pendant soixante-quinze ans, les éléments canadiens-français souvent 
les plus aventureux, les plus novateurs, les plus énergiques, ont choisi d'émigrer. Cette hémorragie a entrainé deux conséquences qui nous ont causé un tort considérable. Premièrement, une certaine stagnation. Si l'on étudie notre histoire, de 1850 à 1925, il faut constater une inertie sociale qui n'existait pas avant 1850 et qui n'a cessé qu'après 1925, quand les Canadiens français ont cessé de se diriger vers les États-Unis, Cette déperdition d'énergie n'a sûrement pas été sans retarder notre évolution juridique. En second lieu, nous n'avons pas eu dans la province de Québec ce que l'on a appelé le frontier spirit aux États-Unis, dans l'Ontario ou dans l'Ouest canadien. Même les états de l'Est américain se sont ressentis des bienfaits de ce frontier spirit. Or, ce stimulant nous a manqué. Il n'y a qu'à songer à l'Abitibi et au Lac-Saint-Jean, où cette mentalité novatrice est agissante pour regretter qu'elle ait été inexistante dans le reste du Québec. Nous avons laissé faire l'industrialisation sans réagir.

Le quatrième facteur - et c'est peut-être la constatation la plus affligeante est que l'ouvrier canadien-français a perdu contact [p. 132] avec son groupe social et culturel beaucoup plus rapidement et beaucoup plus complètement que l'ouvrier américain ou même l'ouvrier ontarien. Le Canadien français s'est prolétarisé très vite, il a perdu le sens de sa propre culture qui a persisté dans les campagnes et dans les classes moyennes. Il a également perdu les habitudes sociales anciennes, avec le résultat qu'il est devenu, plus que l'ouvrier américain, un isolé.

De ces divers phénomènes ont résulté trois conséquences principales qui ont eu une influence directe sur notre évolution juridique. Les ouvriers canadiens-français, ainsi coupés de tout lien avec leur milieu culturel, sont moins conscients que les ouvriers américains d'un besoin d'institutions et de règles juridiques nouvelles pour supprimer les maux dont ils souffrent. Ils sont plus apathiques, plus inertes. La deuxième conséquence est que l'ouvrier canadien-français a été « éveillé » par les «étrangers ». C'est le syndicalisme américain qui est venu dire aux ouvriers canadiens-français : «Organisez-vous en syndicats, établissez chez-vous au moins deux institutions : le syndicalisme et la convention collective. » On les a établies, de 1890 à 1925 ou 1930, à la façon de tous les pays industriels, c'est-à-dire avec assez de violence, d'autant plus que les cadres juridiques existants ne suffisaient pas à régir les problèmes nouveaux. Troisième conséquence : cette attitude de la classe ouvrière dirigée par des chefs syndicalistes américains ou des chefs canadiens formés au syndicalisme américain, a provoqué une vive opposition, et, disons le mot, une forte animosité de la part de la classe rurale et des classes moyennes canadiennes-françaises. En conséquence, le pouvoir politique, dominé par les classes rurales et par les classes moyennes (tant à Ottawa que dans le domaine provincial), n'a légiféré dans le domaine industriel qu'à contrecœur et presque trop tard.

Deux autres exemples, parmi les plus importants, permettront de noter les étapes typiques des processus selon lesquels se sont élaborés dans notre société, l'établissement de formes juridiques nouvelles et l'institutionnalisation de mouvements sociaux. Le premier est celui de notre « Loi des Accidents du travail». Cette mesure de sécurité sociale répond à un besoin qui s'est 
manifesté très tôt dans notre province comme dans tous les pays, dès que sont apparues les industries de type moderne. L'artisan d'autrefois contrôlait ses outils et en était généralement propriétaire. Il était aussi le [p. 133] maître de son propre travail et, par conséquent, son risque d'accident était réduit au minimum. L'artisan pouvait, jusqu'à un certain point, contrôler le risque d'accident. Dans l'industrie moderne, au contraire, l'ouvrier n'est pas propriétaire de la machine et ne la contrôle pas. La machine, très souvent, est contrôlée par des ingénieurs et par des ouvriers spécialisés. L'ouvrier ne travaille pas seul mais dans une usine complexe, en compagnie d'un grand nombre de personnes. Il n'est pas son propre maître : d'où, pour lui, risque d'accident accru, risque d'accident incontrôlable. La société industrielle crée l'insécurité. Il est donc juste que ce soit la société industrielle elle-même qui garantisse la sécurité du travail et soit responsable de la sécurité « sociale. »

Or, que disait à ce sujet le droit au début du $\mathrm{XX}^{\mathrm{e}}$ siècle, il y a à peine cinquante ans? La règle générale était que «celui qui fait tort à autrui est responsable des dommages qu'il cause par sa faute ou par son fait » (je cite librement l'article 1053 de notre code civil). Celui qui subissait un accident avait donc ce qu'en procédure on appelle le «fardeau de la preuve.» En d'autres termes, c'est l'ouvrier blessé qui devait prouver que le patron était en faute avant de pouvoir toucher une indemnité. S'il ne parvenait pas à établir cette preuve, il perdait son procès et ne recevait aucune indemnité. Une enquête menée vers 1893 dans diverses grandes industries révéla que sur 100 accidents, il y en avait 12 que l'ouvrier gagnait, 20 où les tribunaux décidaient que l'accident était survenu à la suite de la faute de l'employé et enfin 68 où l'ouvrier, incapable de prouver hors de tout doute la faute de l'employeur, perdait tout recours et devait subir son mal sans espoir. Ainsi, 88 pour cent des ouvriers accidentés n'étaient pas indemnisés pour dommages subis dans les établissements industriels à la suite d'accidents du travail.

On a d'abord essayé de contourner la loi existante ou de se servir des textes existants et on a fait valoir le raisonnement suivant «Le propriétaire est responsable des accidents causés par sa chose or, l'accident est causé par l'usine; donc, aucune nécessité d'une nouvelle loi: sauf le cas de faute de l'ouvrier, c'est le patron qui sera responsable puisque c'est l'usine qui a causé l'accident. » Mais il subsistait un très grand nombre de cas où l'ouvrier était en faute ou ne pouvait pas prouver que c'était la faute du patron qui avait causé directement le dommage.

\section{[p 134]}

On eut alors recours (c'est une décision de notre Cour Suprême du Canada en 1909, dans la cause de la Shawinigan Carbide Co. vs Doucet, 42 Can. S.C.R., p. 281) à la notion de « responsabilité contractuelle». Le raisonnement juridique devint le suivant: «Au moment du contrat de travail, l'employé s'engage à travailler et à être loyal; le patron s'engage à payer un salaire et à garantir des conditions de travail telles que l'employé ne sera ni blessé ni tué à la suite d'un accident de travail. » Cette théorie renversait le fardeau de la preuve. C'était dorénavant le patron qui devait prouver que l'accident était survenu sans sa faute, sinon il devait payer une indemnité à l'ouvrier accidenté. Mais bientôt encore cette fiction légale se révéla insuffisante 
puisque le patron pouvait toujours avoir recours à des avocats et à des experts qui parvenaient à prouver que l'accident ne pouvait avoir été causé par sa faute.

Des juristes français, vers cette époque, firent valoir une nouvelle théorie, celle du «risque créé ». Cette théorie est basée sur l'ancien droit civil (art. 1053 ) et peut se résumer comme suit : "Toute personne qui sait discerner le bien du mal est responsable du dommage qu'elle cause à autrui par sa faute, par son fait ou par sa négligence, inhabilité ou imprudence. Or, c'est le patron qui crée le risque puisqu'il construit une usine avec des machineries. S'il n'y avait pas cette usine et ces machineries, l'ouvrier n'y travaillerait pas et, par conséquent, n'y serait jamais blessé. Donc, comme le patron a créé l'usine, il a créé le risque et, par son fait, virtuellement, dès le début, il est cause du dommage que subit l'ouvrier lors d'un accident de travail. " Cette théorie, proposée par les auteurs français, fut repoussée par nos juristes, entre autres, par le plus célèbre d'entre eux, P.-B. Mignault. Mais, paradoxalement, au moment où elle était repoussée par nos juristes et nos tribunaux, elle fut acceptée par les législateurs.

En 1909, les législateurs québécois, constatant que ces diverses façons d'interpréter la loi existante ne satisfaisaient plus aux besoins de sécurité dans les établissements industriels, édictaient la première "Loi des accidents du travail ». La base de cette loi est précisément la théorie du « risque créé ». On y dit: "L'ensemble des industries crée des risques; par conséquent, c'est l'ensemble des industries qui doit indemniser les ouvriers lorsqu'ils subissent un dommage par suite d'un accident de travail. » Cette loi a subi une évolution assez intéressante qui s'est répétée pour [p. 135] presque toutes nos lois ouvrières ou sociales depuis une quarantaine d'années, Au début, on a simplement créé une loi administrée par les tribunaux de droit commun. Peu à peu, à la suite d'une série d'amendements, on a remplacé le tribunal de droit commun par un tribunal administratif. Plus tard, à ce tribunal administratif luimême on a substitué un simple service administratif. En d'autres termes, pour disposer de chacun des 80,000 à 90,000 cas d'accidents de travail qui sont rapportés chaque année dans l'industrie québécoise, il existe une procédure, prévue par la loi, qui entre automatiquement en jeu en vue d'indemniser l'ouvrier. Le droit civil traditionnel a vite été complètement abrogé en ce domaine.

Le second exemple qui doit retenir notre attention est celui du syndicalisme. Le syndicalisme a commencé chez nous vers 1828 . Dès 1828 , il existait à Montréal un syndicat d'imprimeurs. Ce syndicalisme était en marge de la loi puisque, d'après le droit en vigueur dans les provinces anglaises aussi bien que dans la province de Québec, toute association destinée à améliorer les conditions de travail des ouvriers constituait une entente concertée, une « conspiration » pour faire hausser les prix des marchands. Des syndicats de ce genre réussirent cependant à vivoter jusque vers 1872. En 1872, à la suite d'une grève réprimée assez brutalement, à Toronto, le Parlement fédéral donnait droit de cité ou existence légale aux syndicats ouvriers. Bien que cette loi s'appliquât à la province de Québec, les syndicats ouvriers continuèrent d'y être considérés d'un mauvais œil. On les disait inspirés par le syndicalisme 
américain. On les considérait comme dirigés par des étrangers et l'on s'attaquait à leur caractère de neutralité ou de non-confessionnalité. Jusqu'en 1898, nos tribunaux ne voulurent pas admettre l'action du syndicalisme et il fallut une décision de la Cour Suprême du Canada (dans la cause de Perrault vs Gauthier, 28 Can. S.C.R., p. 241) en 1898, pour que les tribunaux de la province de Québec admettent l'existence des syndicats ouvriers. Il faudra même attendre une décision de notre Cour d'appel, en 1942, pour que les tribunaux de la province de Québec affirment, une seconde fois et de façon non équivoque, la parfaite légalité du syndicalisme ouvrier.

Cette attitude de nos tribunaux était purement négative et réactionnaire. Il y eut, d'autre part, dans notre province, une [p. 136] attitude " constructive " envers le syndicalisme. L'idée en germa à la suite de l'intervention du cardinal Bégin dans une grève de cordonniers, vers 1902, et se réalisa en 1921 lorsqu'on fonda les Syndicats catholiques. Le syndicalisme catholique et « national », ou « catholique et canadien-français », a constitué, à mon avis, une résistance constructive au syndicalisme d'origine américaine. À la suite d'une évolution assez longue, ce syndicalisme catholique est devenu un cadre de plus en plus dynamique du mouvement ouvrier dans la province de Québec. Bien plus, il pose le problème du pluralisme syndical, puisqu'il coexiste avec d'autres fédérations syndicales qui se partagent la classe ouvrière. Ces divers groupes se font entre eux une concurrence de bon aloi qui les oblige à maintenir des normes élevées d'activité syndicale.

En conclusion, on peut d'abord répéter que le décalage est inévitable entre l'apparition de certains mouvements sociaux et la législation destinée à régir les nouvelles relations sociales résultant de ces changements. Non seulement ce décalage est inévitable mais il est nécessaire. Il est important de ne pas légiférer à la hâte ni d'édicter de lois qui ne conviendraient pas aux sujets qu'elles sont appelées à régir. Remarquons aussi que notre évolution juridique s'est cristallisée dans une législation à la fois massive et confuse. Les lois s'ajoutent les unes aux autres ; assez souvent elles se contredisent. Néanmoins, bien qu'il y aurait un grand nombre d'améliorations à apporter, j'estime qu'il y aurait danger de vouloir rationaliser trop vite, de vouloir codifier dès maintenant, de façon définitive, notre législation ouvrière. Notre évolution économique et sociale n'est pas terminée et il serait imprudent, à mon sens, de décréter une fois pour toutes que la législation ouvrière doit aller « jusque-là » et pas plus loin.

À raison de la complexité croissante de nos problèmes économiques et sociaux, il faudrait accorder, dans notre province, une plus grande importance aux recherches sociales afin qu'une opinion publique plus éclairée soit en mesure de réclamer ce perfectionnement sans cesse renouvelé de la législation qu'exigent les conditions toujours modifiées de notre existence collective. 


\title{
COMMENTAIRES
}

\author{
Eugène Forsey
}

$\underline{\text { Retour à la table des matières }}$

Si les dimensions du sujet traité par M. Perrault semblent «vastes » à un juriste, combien plus encore le paraissent-elles à un observateur qui n'est ni juriste, ni sociologue. Quels jugements peut porter sur « l'évolution juridique du Québec » celui dont l'intérêt juridique s'est surtout concentré sur le droit constitutionnel dans la perspective (caractérisée comme «barbare» par le professeur Frank Scott) de la common law anglaise? Par ailleurs, les mouvements sociaux ne se composent ni de savants ni de juristes: ils entraînent ou mobilisent les masses, dont nous sommes tous. L'évolution juridique impose de nouvelles normes de comportement à tous et à chacun des participants du drame social, dans toutes les sphères d'activité humaine, qu'il s'agisse de la finance, du commerce, du travail ou de la vie privée. C'est dans cette optique de l'acteur social moyen que je veux considérer quelques aspects des problèmes soulevés par le précédent chapitre.

Dans l'ensemble, je suis d'accord avec les propositions et les conclusions générales de $M$. Perrault, mais je ne partage pas tout à fait son opinion sur la nature de notre droit constitutionnel vers 1890, au moment des débuts de l'industrialisation du Québec. « Le droit constitutionnel qui établissait alors les normes d'équilibre entre le pouvoir fédéral et les pouvoirs provinciaux, écrit M. Perrault, avait été promulgué en 1867, à une époque où l'industrialisation du pays n'était pas vraiment commencée. Et nous n'avons pas encore pu, ou nous n'avons pas su nous débarrasser en 1953, de cette Constitution de 1867 qui n'a pas été faite (que l'on soit centralisateur ou autonomiste) pour une société industrielle comme la nôtre. »

Je précise tout d'abord que je ne suis personnellement ni «centralisateur » ni «autonomiste». Ma position pourrait assez bien se caractériser en transposant la phrase fameuse de l'ancien premier ministre du Canada, M. Mackenzie King: "Not necessarily centralization, but centralization when necessary. » En d'autres termes, je suis en faveur des autonomies provinciales dans toute la mesure du possible, tout en reconnaissant que des problèmes tels que la [p. 138] défense et le commerce international ne peuvent être adéquatement résolus que sur le plan national. Or, les "Pères» de la Confédération canadienne ont bien défini les problèmes qui, par leur nature même, exigent la centralisation. Bien plus, je soumets que même si la Confédération fut instituée avant l'industrialisation du pays, la Loi de 1867, 
loin d'être surannée, contient des principes à la lumière desquels nous pouvons valablement poser et résoudre les problèmes de notre société industrielle.

En premier lieu, les Pères de notre Confédération, à l'encontre des Pères de la Constitution américaine, ne dressèrent aucune liste des domaines où prévaudrait la juridiction fédérale. Au contraire, ils statuèrent explicitement : "Il sera loisible à la reine, de l'avis et du consentement du Sénat et de la Chambre des Communes, de faire des lois pour la paix, l'ordre et le bon gouvernement du Canada, relativement à toutes les matières ne tombant pas dans les catégories des sujets par le présent Acte exclusivement assignés aux législatures des provinces; mais, pour plus de garantie, sans toutefois restreindre la généralité des termes ci-haut employés dans cette section, il est par le présent déclaré que (nonobstant toute disposition énoncée dans le présent Acte) l'autorité exclusive du Parlement du Canada s'étend à toutes les matières tombant dans les catégories ci-dessous énumérées, savoir : ... »-suit une liste de ces matières. Cette liste ne renferme donc que des exemples de la juridiction fédérale. Celle-ci s'étend à la paix, l'ordre et le bon gouvernement du Canada, sauf les exceptions énumérées aux articles 92 et 93.

Je veux, à ce propos, citer quelques paroles de Sir John A. Macdonald, au cours des débats sur la Confédération, en 1865: «En fait, les Américains commencèrent par où ils auraient dû finir ... Ici nous avons adopté un système différent : nous avons concentré la force dans le gouvernement général. Nous avons déféré à la législature générale toutes les grandes questions de législation. Nous lui avons conféré, non seulement en les spécifiant et détaillant, tous les pouvoirs inhérents à la souveraineté et à la nationalité mais nous avons expressément déclaré que tous les sujets d'un intérêt général, non délégués aux législatures locales, seraient du ressort du gouvernement fédéré et que les matières locales seraient du ressort des gouvernements locaux ... Toutes les grandes questions affectant les intérêts de la Confédération dans son ensemble [p. 139] sont laissées au parlement fédéral, tandis que les questions et les lois d'intérêt local sont laissées à la juridiction des parlements locaux ... À part tous les pouvoirs spécialement désignés dans le $37^{\mathrm{e}}$ et dernier article de cette partie de la Constitution, se trouve conférée à la législature générale la grande législation souveraine, c'est-à-dire le pouvoir de légiférer sur toutes les matières d'un caractère général qui ne seront pas spécialement et exclusivement réservées au contrôle des législatures et des gouvernement locaux. Telle est justement la disposition qui manque à la Constitution des États-Unis ; c'est là où l'on trouve ce côté vulnérable du système américain, le vide qui enlève à la Constitution américaine sa force de cohésion. C'est là ce que l'on peut appeler une sage et nécessaire disposition. Par elle nous concentrons la force dans le parlement central et faisons de la Confédération un seul peuple et un seul gouvernement, au lieu de cinq peuples et cinq gouvernements ... une province unie, avec des gouvernements locaux et des législatures subordonnés au gouvernement fédéré et à la législature générale. »

Ce que les Pères de la Confédération nous donnèrent, ce fut une Constitution très souple, susceptible de se développer selon l'évolution économique et sociale du pays; une Constitution qui pouvait s'adapter à l'industrialisation. J'en trouve la preuve non seulement dans les quelques 
déclarations de Macdonald lors des débats de 1865, mais dans des lois et des projets de loi aux débuts de l'industrialisation ontarienne qui devança celle du Québec. En 1872, le parlement fédéral vota une «Loi des Associations ouvrières ». À peu près personne ne mit en cause à ce moment la juridiction du Dominion en cette matière. En 1882, en 1883 et en 1884, le gouvernement de Sir John A. Macdonald, dont cinq ministres étaient des Pères de la Confédération, présenta au Parlement des projets de loi touchant les offenses contre les personnes employées dans les fabriques (Factory Bills), projets tout à fait semblables aux lois d'Angleterre et du Massachusetts en ce domaine. De plus, en 1884, quand l'Assemblée législative d'Ontario vota une loi de même nature, le lieutenant-gouverneur informa le ministre fédéral de la Justice qu'il doutait de la constitutionnalité de la loi et proposa qu'on demande à ce sujet l'opinion de la Cour suprême du Canada. La décision du Conseil privé dans le cas de la Loi McCarthy porta la première atteinte sérieuse au pouvoir du gouver-[p. 140] nement fédéral de légiférer pour « la paix, l'ordre et le bon gouvernement du Canada ». Malgré ces événements, la Constitution canadienne, en 1890, restait cependant à peu près intacte, à peu près identique à celle que nous avaient donnée les Pères de la Confédération.

Ce n'est qu'en 1892, à l'occasion de la cause de la Maritime Bank of Canada vs the Receiver-General of New Brunswick, que commença l'œuvre néfaste des «Beaux-Pères » de la Confédération, le Conseil privé anglais. Cette œuvre consista à gonfler les pouvoirs provinciaux aux dépens des légitimes pouvoirs fédéraux tels que ceux-ci avaient été conçus et exercés par les Pères de la Confédération. Elle fut amorcée par Lord Watson en 1892 et achevée par Lord Haldane, dans le cas Snider en 1925. C'est cette œuvre qui a fini par bouleverser et détraquer le sens de notre Constitution touchant les matières de juridiction fédérale et de juridiction provinciale.

L'équilibre entre le pouvoir fédéral et les pouvoirs provinciaux avait été fixé en 1867. Nous reconnaissons qu'à cette époque l'industrialisation du pays n'était pas commencée ou à peine, et que la Constitution de 1867 n'a pas été expressément conçue pour une société industrielle comme la nôtre. Mais ce qui nous importe, c'est qu'elle avait été conçue de telle sorte qu'elle pouvait s'adapter aux besoins croissants d'un pays qui allait s'industrialiser. Or, nous n'avons plus cette Constitution. Le brave Watson et son disciple Haldane nous ont donné un substitut, une Constitution mi-canadienne, mi-écossaise, qui n'est incontestablement pas faite pour une société industrielle comme la nôtre et qui est presque incapable de s'y adapter. Voilà, à mon avis, en quoi consiste notre problème constitutionnel vu sous son vrai jour. La faute n'est pas celle de la Constitution de 1867. C'est celle des juges étrangers qui l'ont dénaturée.

Ces propos peuvent paraître pédants et ne toucher que de très loin le sujet des mouvements sociaux et de l'évolution juridique du Québec contemporain. Je crois cependant que si nous avions pu garder notre Constitution canadienne contre l'invasion des juges-philosophes écossais qui nous ont imposé leur propre conception du fédéralisme au lieu de celle de Cartier et de Macdonald, nous aurions un droit industriel fédéral, bien différent de celui que nous avons en ce moment.

[p. 141] 
On me permettra à ce sujet une dernière remarque touchant un phénomène qui me semble étonnant; comment se fait-il que la grande majorité des Canadiens, d'origine anglaise comme d'origine française, ne regrettent aucunement la disparition de notre propre Constitution canadienne de 1867, mais sont, au contraire, fermement, voire farouchement, attachés à notre Constitution étrangère d'aujourd'hui ? Quelle est l'explication de ce paradoxe ? Je lui trouve, pour ma part, quatre causes principales. En premier lieu, la Constitution originelle, en substance, continue d'exister ; ce n'est qu'une partie, bien qu'une partie très importante qui est disparue. En second lieu, cette révolution constitutionnelle a été faite par un tribunal et non pas par une législature ou par une élection. Cela lui donne un air d'impartialité, de pure rationalité. Troisièmement, l'extension des pouvoirs provinciaux répond au sentiment profond de patriotisme local, sentiment aussi fort et aussi répandu dans les autres provinces que dans le Québec. Enfin, la diminution des pouvoirs fédéraux et l'accroissement des pouvoirs provinciaux convenaient aux intérêts des classes dirigeantes, lesquelles préféraient avoir affaire à plusieurs législatures provinciales qu'à un seul Parlement national : divide et impera. La loyauté de classe l'emporte quelquefois sur le patriotisme !

Inutile de poursuivre ces pensées. Nous avons un droit industriel québécois : il est peut-être « fort, rayonnant et beau ; » il ne l'est peut-être pas. Mais il existe, et $M$. Perrault en a décrit la genèse avec la sérénité du juriste. Je tiens à souligner comme étant d'une importance capitale ce qu'il dit du sentiment répandu parmi les classes dirigeantes, à savoir, la crainte que toutes les innovations, "même celles que rendent nécessaires les circonstances économiques et sociales actuelles ... auront pour effet d'introduire chez-nous des principes juridiques inspirés du droit anglo-saxon ou américain, incompatible avec le droit français et devant entraîner la disparition de ce dernier ». C'est là, à mon avis, un facteur excessivement important et peu compris chez les Canadiens de langue anglaise. En France, comme le dit M. Perrault, " on a pu bouleverser le droit civil », sans danger de désintégration culturelle. Au Canada, îlot circonscrit par un océan de culture anglo-saxonne, la situation était entièrement différente, d'où une plus grande rigidité du droit industriel de la province de Québec.

[p. 142]

Un mot, pour terminer, des mouvements sociaux du Québec et, plus particulièrement, de celui qui, à notre époque a manifestement acquis le plus de signification et d'importance: le syndicalisme catholique. M. Perrault affirme que le syndicalisme catholique québécois « a constitué une résistance constructive au syndicalisme américain ». Je suis d'accord et je précise : " de plus en plus constructive, mais de moins en moins résistante!» M. Perrault ajoute que ce syndicalisme « est devenu un cadre de plus en plus dynamique du mouvement ouvrier dans la province de Québec ». Ici encore je vais plus loin et je complète : le syndicalisme catholique constitue maintenant l'avantgarde du mouvement ouvrier dans la province. C'est là un fait incontestable. Mais il n'en fut pas toujours ainsi. Autrefois, les syndicats catholiques n'étaient guère que des ombres, des illusions, des company unions travesties sous un voile de religion. Depuis quelques années, il nous semble qu'une révolution 
s'est produite au sein du syndicalisme catholique. Nous considérons maintenant les syndicats catholiques comme de vrais syndicats, nous en saluons les chefs comme des collègues respectés, comme des confrères, comme de vrais chefs ouvriers que nous admirons tous. Je crois qu'il existe également chez eux un sentiment de fraternité envers nous. Voilà pourquoi je prétends que le syndicalisme catholique devient de moins en moins une résistance contre le syndicalisme dit «orthodoxe» ( - je ne dis pas: d'inspiration américaine, car le syndicalisme non-confessionnel au Canada s'inspire en grande partie du Canada lui-même et aussi de la Grande-Bretagne d'où lui viennent quelques uns de ses meilleurs chefs.) L'allusion à une " résistance » signifie qu'il y a un ennemi dans les environs. Or, au moins pour nous du Congrès canadien du Travail, la C.T.C.C. n'est plus une confédération ennemie mais une confédération-sœur avec laquelle nous collaborons quotidiennement et de plus en plus cordialement.

M. Perrault note enfin que, dans le Québec, le syndicalisme catholique " pose le problème du pluralisme syndical, puisqu'il coexiste avec d'autres fédérations syndicales qui se partagent la classe ouvrière. Ces divers groupes se font entre eux une concurrence de bon aloi qui les oblige à maintenir des normes élevées d'activité syndicale ». Je sens qu'il est en faveur de ce pluralisme syndical et je reconnais les avantages qu'il en signale. Il est cependant intéressant de souligner que ce pluralisme syndical [p. 143] québécois fut, en quelque sorte, une nécessité historique. C'est dans le Québec que s'est manifesté la première tentative délibérée de coopération entre les divers mouvements syndicaux parce qu'une telle coopération y était un besoin plus impérieux que dans toute autre province du Canada. Le syndicalisme québécois, bien qu'il évolue à un rythme de plus en plus rapide, demeure plus faible que dans la plupart des autres provinces. La classe patronale québécoise est plus forte; le gouvernement provincial ne semble guère sympathique envers le syndicalisme, que celui-ci soit « catholique » ou « international».

Le pluralisme syndical possède d'incontestables avantages. Mais je crois que l'opinion ouvrière devient de plus en plus favorable à l'unité syndicale. C'est là notre idéal. Nous ne pouvons l'atteindre que très lentement. La voie qui y conduit est pleine de difficultés et d'obstacles considérables, d'ordre personnel, institutionnel et idéologique. Tous les centres confédéraux veulent garder leurs propres croyances, leurs propres traditions, leur propre conception de la forme d'organisation qui répond le mieux aux besoins des travailleurs. Chacun a ses chefs respectés et puissants. L'unité qui réconciliera toutes les différences, sans violer les principes et les convictions de qui que ce soit, ne sera pas facile à accomplir. Mais, à mon avis, la tâche s'impose, si nous voulons réellement un mouvement ouvrier efficace, une évolution saine et assez rapide du droit industriel en même temps que le bien-être et le progrès de notre pays tout entier. 
[p. 145]

\title{
CHAPTER VII POLITICAL TRENDS
}

\author{
H. Mason Wade
}

$\underline{\text { Retour à la table des matières }}$

French Canada's political history has always been oriented by the principles of cultural survival and recognition of its rights. But it is worthwhile to examine soberly the facile observation that «plus ça change, plus c'est la même chose ", even when we find Errol Bouchette proclaiming at the opening of the period under discussion, «Emparons-nous de l'industrie!" and we hear the same cry today. History never quite repeats itself, and it is analogies rather than exact parallels which lend interest to historical studies.

At the turn of the century, French Canada was involved in one of the crises which have periodically set it at odds with English Canada. The Boer War split wide open the cleft between French and English Canadians which had been developing for some years, and created a deep division which lasted until recent years. The ethnic division caused by the Riel Rising of 1885 , and by the bitter disputes which ensued over the rights of the French language outside Quebec, was furthered by the interplay of two great and opposed forces, nationalism and imperialism. Though English Canadians were then aligned largely in the imperialist camp and French Canadians in the nationalist one, in fact Canadian nationalism in the post-Confederation period was English in origin, and in the last analysis ever since 1763 the French Canadians have placed a greater reliance on the British connection than their fellowcountrymen, since it affords a certain security to a minority group which has sometimes lacked confidence in the goodwill of the majority. Only in recent years have the French Canadians realized that all English Canadians are not imperialists, and that indeed many of them are as strong Canadian nationalists as any French Canadian.

When the agitation began for a Canadian contingent for South Africa, La Presse expressed the fundamental French-Canadian [p. 146] attitude toward foreign wars, which was later to cause two more major wartime crises in Canada's national life: "We French Canadians belong to one country, Canada ; Canada is for us the whole world; but the English Canadians have 
two countries, one here and one across the sea. " The "pan-Anglo-Saxon " idea not only largely swallowed up early English-Canadian nationalism; it stimulated French-Canadian nationalism, with its strong tendency toward isolationism, and thus largely defeated the chief purposes of its prophets. The situation was a perfect illustration of J. A. Hobson's observation that « aggressive imperialism is an artificial stimulant of nationalism in peoples too foreign to be absorbed and too compact to be permanently crushed. » Canada was singularly fortunate in being governed during fifteen crucial years of this conflict by a French-Canadian Prime Minister who possessed an equal devotion to the spirit of British political institutions and the ideal of Canadian nationhood, and who was able to rally most of his compatriots behind his leadership. But in the end he was driven from office on the eve of the far greater crisis of the First World War by a momentary combination of extreme nationalists and aggressive imperialists, political enemies on either side of the middle path he always favoured. For French Canada, with its devotion to the leader principle, the conflict between nationalism and imperialism is largely the story of Laurier and Henri Bourassa.

We know a good deal about Laurier, who has been studied both sympathetically and critically. But oddly enough no one has even written a biography of Bourassa, much less a careful study of his ideas. Yet in the last analysis, it was Bourassa who started his political life as one of Laurier's favourite bright young men, who brought about the downfall of one of Canada's greatest prime ministers by depriving him of Quebec's support. Bourassa first broke with Laurier on the issue of Canadian participation in the Boer War, and he evolved a new French-Canadian nationalism in reaction to imperialist jingoism. This nationalism was largely a reiteration of the doctrines of the «Canada First » movement in French-Canadian terms. It was stimulated by waving of the Union Jack in school and press, by the swelling tide of British immigration, and the great influx of British capital between 1900 and 1913 ( $\$ 1 \frac{1 / 2}{2}$ billion). It shared in the rapidly developing [p. 147] national consciousness brought about by the settlement of the West and by the industrial development of the East, which to some extent broke down the old provincialism. Laurier expressed this aspect of the new nationalism when he called Canada «the country of the twentieth century». After an early inclination towards imperialism, to offset Conservative charges of Liberal annexationist leanings ; to meet English Canada, then in the full flood of imperialist sentiment, halfway; and since British preference suited Canada's needs after the adoption of the McKinley and Dingley tariffs - Laurier reconciled in some measure the ideals of nationalism and imperialism, having learned the danger in Quebec of yielding too much to Ontario's sentiments, and having experienced the full measure of British imperial federation propaganda. He helped to evolve the modern theory of the British Commonwealth of Nations by stressing Canada's position as an autonomous nation within the Empire.

Bourassa's nationalism was not merely a reaction against imperialism; it was a reaction against the attempt of certain English Canadians since 1885 to make Canada a land of one tongue and one culture, and to treat the French Canadians as foreigners in their own country. Unfortunately for Canadian 
national development, many of the leaders of the imperialist movement were also leaders in the anti-French movement; their "Anglo-Saxon » racism and appeals to British traditions fostered the development of racist feeling in Quebec and a reassertation of Quebec's French traditions. Attacks on the privileges of the French-Canadian minorities outside Quebec developed a French-Canadian group consciousness, a sense of « racial and religious separateness ». The massive immigration directed by Clifford Sifton, whose anti-French sentiments had been made clear in the Manitoba school question, led the French Canadians to suspect a plot to swamp them in an Englishspeaking Canada in which Quebec would have little voice or importance. Each year the young men in the classical colleges became more intent upon stressing their Frenchness and their Catholicity; even the infant labour movement developed national, that is, provincial syndicates as rivals to the national and international unions, while opposition arose to the development of Quebec's natural resources by English and American capital under EnglishCanadian auspices. For some, the new sense of separate-[p. 148] ness involved merely an effort to maintain the faith and culture of French Canada against "Anglo-Saxon» encroachment, while freely collaborating with English Canadians in building up a nation of dual culture. For a more narrow-minded group, it meant a withdrawal within the Chinese Wall of an exclusive and isolated French and Catholic province. For them nationalism was really provincialism, but the movement was not provincial in outlook at the start.

Like his grandfather Louis-Joseph Papineau, Bourassa combined an admiration for British institutions with a passionate devotion to French Canada. Thanks to his experience in negotiating the Laurier-Greenway Agreement in 1896 and as secretary of the Joint High Commission in 1898 and 1899, Bourassa had wider political horizons than most young Quebec politicians. He saw through and denounced the dangerous double game played by both traditional parties : "In the English-speaking provinces, both parties run for the prize of "loyalty" - each side claiming the credit of having done the most for Great Britain. Of sole devotion to Canadian interests, we hear no more ... The only point in real dispute is which will eat the biggest piece of the jingo pie. All this, of course, does not prevent them from selling Canada wholesale to American railway magnates. In Quebec ... it is no longer a question of which party has done more for Great Britain, but the less done, the greater credit claimed. » He feared that this double game would lead to a clash between French and English Canadians, which might end in annexation to the United States.

At the outset, Bourassa displayed an attitude towards imperialism which was at once Canadian and in accordance with the best traditions of English Liberalism. His ideas were not very different from those of Goldwyn Smith, except that he was much more reluctant to envisage the end of the British connection than the Toronto prophet of annexation. His opposition to imperialism made him the hero of the young anglophobe French-Canadian students, who envisaged the formation of a French-Canadian party which would make no concessions to imperialism, as both Conservatives and Liberals had done. 
As Laurier's success gradually eclipsed the Conservative Party, Bourassa became the leader of those French Canadians, particularly the younger generation, who found the Liberal chief too willing to compromise with imperialists and the English Canadians.

[p. 149]

Bourassa's vanity was too great for him not to accept this role, and he did not strongly condemn his followers' anti-English excesses, with which he was not personally in sympathy. In Montreal, Louvigny de Montigny and Olivar Asselin launched a weekly called Les Débats in 1900 which publicized Bourassa's parliamentary skirmishes against imperialism; in Quebec Armand Lavergne distributed Les Débats to Laval students ; in St. Jérome the Nantels published La Nation, with a programme of seeking independence through constitutional means and opposing imperialism. At Drummondville, in June 1902, Napoléon Garceau organized the first mass nationalist meeting, which adopted resolutions of fidelity to French-Canadian nationality and to its constituent elements of faith, language, laws, and traditions, and to the British Crown. Bourassa's ideas received the sanction of $\mathrm{M}^{\text {gr }}$ L.-A. Pâquet, the noted theologian and sacred orator, in his 1902 Saint-Jean-Baptiste Day sermon at Quebec, which hymned the vocation of the French race in North America: "Our mission is less to manipulate capital than to change ideas; it consists less in lighting the fires of factories than to maintain and to make shine afar the luminous fire of religion and thought. » This sermon was a classic example of the messianic nationalism derived from Bossuet and de Maistre, which was to become dominant in later years, tinged with more than a suspicion of sour grapes.

The group of young nationalists who had cut their teeth as contributors to Les Débats founded the Ligue Nationaliste in March 1903. The League's threefold programme, which had been drafted by Olivar Asselin and approved by Bourassa, read thus :

«1. For Canada, in its relations with Great Britain, the largest measure of autonomy compatible with the maintenance of the colonial bond.

«2. For the Canadian provinces, in their relations with the federal power, the largest measure of autonomy compatible with the maintenance of the federal bond.

«3. Adoption by the federal and provincial governments of a policy of Canadian economic and intellectual development. »)

Meanwhile another nationalist group, fired by the spirit of $\mathrm{M}^{\mathrm{gr}}$ Pâquet's messianic nationalism, had grown up since 1900 in the classical colleges of the Montreal region under the direction of Abbé Lionel Groulx, Abbé Émile Chartier and Père Hermas [p. 150] Lalande, s.j. What had begun as a religious movement soon acquired strong political overtones, and the Association catholique de la Jeunesse canadienne-française became the nursery of twentieth century French-Canadian nationalism. Its confusion of religion and 
patriotism was soon carried into every walk of Quebec life by the heady indoctrination which the young élite received in its ranks. Laurier took alarm at these developments and intervened with both Archbishop Bruchési and Bourassa. He got the former to moderate the A.C.J.C.'s enthusiasm for the Drapeau Carillon Sacré-Cœur, and he warned Bourassa of the danger of forming a French party in Quebec which would produce an anti-FrenchCanadian reaction in Ontario. Laurier was indulgent both towards Bourassa and Armand Lavergne, but he was very conscious of Lord Elgin's warning of the danger of racial or religious parties in Canada.

Asselin's Ligue founded a weekly, Le Nationaliste, in March 1904. The paper was to be absolutely independent of both traditional parties. Asselin's chief aid was Jules Fournier, a brilliant young journalist of A.C.J.C. background. While Bourassa disowned any responsibility for Le Nationaliste, it was clearly his organ. The paper was nationalist in a Canadian sense, not merely in a French-Canadian one, and as such its appearance was welcomed by two leading English-Canadian nationalists, Goldwin Smith and John S. Ewart.

The difference between Bourassa's nationalism and that previously known in Quebec was made evident by an exchange between him and Jules-Paul Tardivel, the ultramontane, anglophobe, and separatist editor of La Vérité. Tardivel described his nationalism thus : "Our own nationalism is FrenchCanadian nationalism. We have worked for twenty-three years for the development of French-Canadian national sentiment; what we wish to see flourish is French-Canadian patriotism ; for us, our compatriots are the French Canadians ; for us, our fatherland is - we do not say precisely the Province of Quebec - but French Canada; the nation we wish to see founded at the hour marked by Divine Providence is the French-Canadian nation. These gentlemen of the Ligue appear to take their stand on another point of view. One would say that they wish to work for the development of Canadian sentiment, independent of all questions or origin, language, and religion. »

[p. 151]

Bourassa replied with a definition of the nationalism for which the Ligue stood: "Our own nationalism is a Canadian nationalism founded upon the duality of races and on the particular traditions which this duality involves. We work for the development of a Canadian patriotism which is in our eyes the best guarantee of the existence of the two races and of the mutual respect they owe each other. For us, as for M. Tardivel, our compatriots are the French Canadians ; but the English Canadians are not foreigners, and we regard as allies all among them who respect us and who desire, like us, the maintenance of Canadian autonomy. For us, the fatherland is all Canada, that is, a federation of distinct races and autonomous provinces. The nation that we wish to see develop is the Canadian nation, composed of French Canadians and English Canadians, that is, of two elements separated by language and religion, and by the legal dispositions necessary to the preservation of their respective traditions, but united in a feeling of brotherhood, in a common attachment to the common fatherland. » 
The A.C.J.C. was clearly much more in Tardivel's tradition than in Bourassa's ; but Le Nationaliste adopted a friendly attitude toward the group and Bourassa frequented their meetings. As time passed, the A.C.J.C. became less of a pious confraternity and more of a politico-religious movement, whose support was pledged to Bourassa. Though in 1904 no one rivaled Laurier or matched his hold upon the hearts of Canadians, English and French alike, a groundswell was arising in Quebec which threatened this dominance of his native province. The hero of the young nationalists was Henri Bourassa, not Sir Wilfrid Laurier.

Bourassa introduced a new element into French-Canadian nationalism when he expounded the programme of the Ligue to an audience of 6,000 at Quebec on December 8, 1903. In addition to dealing with Canada's situation in the Empire and with the federal-provincial relationship, he expounded an economic nationalism. He criticized the provincial Liberal administration for selling timber limits on too great a scale, and too frequently to speculators who stripped colonization lots of their wood and then abandoned them. He favoured a law compelling American lumbermen to convert wood into pulp in Quebec mills. He urged that waterpower rights should be leased rather than sold outright. This programme was not very much to the taste of the leading [p. 152] Liberals on the platform, but it was cheered by the students as heartily as Bourassa's political proposals Despite Bourassa's numerous subsequent appeals for more support for colonization, not until after the first World War did the economic element become dominant in nationalism; for the battle against imperialism and in defence of French rights outside Quebec had first to be decided.

1905, the year which saw Joseph Chamberlain's retirement from politics, marked the ebb of the imperialist tide in Canada, while anti-imperialism grew ever stronger and reached its flood in 1911. Laurier had steered a clever course between imperialism and autonomy, but two other great achievements of his regime brought about the beginning of his decline. The massive polyglot immigration since 1897, which had peopled the West and added one-third to the nation's population, revived French Canada's fears for cultural survival, chronic ever since 1763. The rapid development of the West called for the creation of new provinces, and this raised once more the question of minority rights, with ethnic and religious difference whose power to disrupt Canadian national life Laurier already knew only too well. For all his political adroitness and his willingness to compromise, he could not avoid a bitter division of the nation and of his following, and with that division the eventual doom of his administration was assured. Bourassa, backed by the Ligue and the A.C.J.C., took an active part in opposing the government's stand on the North-West school question. In the end, a new French-Canadian grievance against the federal government was added to the lengthy list already familiar to the nationalists.

The nationalists were divided by differences in principle between the Ligue, which put nationalism before religion, and the A.C.J.C., which put religion before nationalism. $L a$ Vérité, now edited by Omer Héroux, Tardivel's son-in-law, quarreled with Le Nationaliste. With imperialism on the wane, 
Bourassa now found more frequent occasion to express his French-Canadian patriotism than the larger Canadianism which he had earlier advanced. He attacked an immigration policy which neglected prospective French and Belgian colonists in favour of Polish and Russian Jews. The rapid increase of the Jewish population of Montreal since 1901 had already roused antisemitism among the French Canadians; and Bourassa thus [p. 153] gave expression to what was to become a standard strand in French Canadian nationalism. His fight against the Sunday Bill, supported by the Lord's Day Alliance of Toronto, brought him new support from labour, for the prospect of the extension of the notably cheerless Toronto Sunday to Quebec aroused popular feeling. The great industrialists joined the opposition to the bill, and made their influence felt in the Senate, which imposed amendments embodying Bourassa's suggestions. His political influence increased, and he found himself for the first time in the great English-Canadian interests which were later to make a brief but effective political alliance with him.

Bourassa continued to be a thorn in the flesh of the Gouin administration, denouncing the mismanagement of the province's natural resources and calling for all manner of reforms. He made capital of the fact that he was prevented from addressing a crowd of 1,500 at St. Roch when Liberal stalwarts laid down a barrage of tomatoes, eggs, and stones. The country parishes gave him a fair hearing, and in September 1905 he called for the formation of a third party, "which ought necessarily absorb the best elements of the two old parties. » He accepted a challenge to resign from the federal House and to run against Turgeon. He lost his election, but decided to remain in the provincial field. Laurier summed up his ex-follower's character not too unkindly : « No one recognizes Bourassa's talent more than I do. He has one capital defect, he does not know how to keep within bounds ... he fights his friends with the same violence as his enemies; he becomes intoxicated with his own words; he grows irritated if contradicted; in the end he overshoots his own mark and allows himself to be drawn along unconsciously from friendly criticism to open war. »

His movement gained new journalistic support when in December 1907 the first number of L'Action sociale appeared at Quebec, with Omer Héroux and Jules Dorion, two of his disciples, as editors. Lavergne upheld the nationalist cause in Bourassa's stead at Ottawa. Lavergne's call for bilingualism in the public services was vigorously supported by the A.C.J.C., which was becoming increasingly political. Bourassa's tumultuous young followers had a way of pushing his demands for equality to the point of provocation. To the dismay of Laurier, Gouin, and other prophets of the middle way, the rising generation was nationalist to a man, and (p. 154] increasingly provincial in its outlook. The Liberal press referred scathingly to " the choirboys of the new pontiff»; but the Conservatives urged Bourassa to run against Lomer Gouin in Montreal, the provincial premier, with their support. After Gouin and Taschereau announced their intention of contesting two seats, Bourassa declared that he would also contest St. Hyacinthe. He succeeded in winning both elections, and derived great prestige from defeating the Liberal leader in his own home district. 
The Nationalist-Conservative alliance against the Liberals grew closer, and it was from Conservative sources that Bourassa got some support for his independent journal, Le Devoir, which was launched in January 1910, after an 18-month campaign for funds. Le Devoir's staff included Georges Pelletier and Omer Héroux of L'Action sociale, and Olivar Asselin and Jules Fournier of Le Nationaliste. Both the ultramontane and liberal wings of the nationalist movement were thus reunited. The new paper opposed the Gouin government; it referred to the "betrayals, weaknesses, and dangers" of Laurier's policy; and it espoused the cause of the newly founded Ontario Association canadienne-française d'éducation which had undertaken the defence of bilingualism in that province. Bourassa promptly attacked Laurier's Navy Bill and his statement that Canada was at war when England was at war. Le Devoir organized a campaign for a plebiscite on the Navy question. While the Globe accused Laurier of trying to separate Canada from England, Le Devoir charged that he was sacrificing Canada to England.

The Navy Bill passed; but the anti-imperialist agitation which had been roused in Quebec did not die down. The nationalists and Conservatives launched a joint campaign for repeal of the Navy Act. At St. Eustache in July, Bourassa denounced Laurier for betraying his followers into imperialism, and for denying the Catholics of half the country the right to have their children taught the religion and the language of their fathers. While Laurier campaigned in the West, Bourassa and his Conservative allies held meeting after meeting in Quebec, He won new prestige in September by his spontaneous reply to Archbishop Bourne at the Eucharistic Congress in Montreal, when the English prelate suggested that the English language was the destined vehicle of Catholicism in North America. A by-election in Arthabaska [p. 155] provided a test of strength between Laurier and Bourassa, and the victory of the Nationalist candidate after a bitterly contested election gave warning of Laurier's approaching downfall.

Somewhat surprisingly, Bourassa on the whole supported reciprocity when the issue was before the House early in 1911. But the issue in Quebec was not reciprocity but imperialism, and Bourassa and his followers conducted a vigorous anti-imperialist campaign while Laurier was in London at the Imperial Conference early that summer. In the face of Conservative opposition to the Reciprocity Bill, Laurier was forced to appeal to the country. In Quebec, politics made very strange bedfellows, with Bourassa joining the imperialists Herbert B. Ames and C. J. Doherty in the common cause of defeating Laurier. Protectionist and imperialist big business was willing to use the nationalist movement to defeat reciprocity. Funds began to flow into the nationalist war chest. One English Conservative in Montreal, who had attacked the nationalists as « rebels and disloyal traitors », took out 40 subscriptions to Le Devoir. The paper's capital tripled. Bourassa stressed that the main issue was imperialism, but when the Liberals sought to divert attention from the Navy question by concentrating on reciprocity as a benefit to the farmers of Quebec, Bourassa began to criticize reciprocity. Bourassa encountered Rodolphe Lemieux in an assemblée contradictoire at St. Hyacinthe, which ended with fights on the platform as well as in the crowd. Bourassa found himself eulogized by the Conservative Gazette and the Star, while Le Devoir had 
become a more influential organ than either the liberal La Presse or La Patrie, within a year and a half after its foundation. Its devotion to the cause of the French language won it the support of the clergy as well as the students. After the bitterest campaign in Quebec's memory, the Laurier regime went down to defeat in September 1911, with the loss of 32 seats in Quebec. The majority in the house was exactly reversed. The outcome was hailed in Quebec as a nationalist triumph; in Ontario as an imperialist one. By his fight against Laurier the nationalist Bourassa had delivered Quebec into the hands of an administration committed to imperialism and unsympathetic to the French Canadians. Thanks to the unscrupulousness of the campaign, Canada was already split by bitter ethnic divisions as one of the great crises of its national life drew near.

[p. 156]

Bourassa soon had an opportunity to exercise his talent for opposition, for the Nationalist-Conservative alliance broke down when Robert Borden refused the nationalist programme of a plebiscite on the naval question, a revised immigration policy, and relief for the grievances of the French minority in the West. Bourassa pamphleteered against the Navy Act and against the government's refusal to guarantee minority educational rights when Keewatin was annexed to Manitoba. He protested vigorously against a bill introduced at Ottawa by an Ontario member which would invalidate any provincial or canonical law against mixed marriages. This bill was directed against application of the papal Ne Temere decree in Quebec. These were not successful campaign for the nationalists, and the Gouin government maintained its majority, thanks to a reaction in favour of Laurier when the Nationalist-Conservative alliance failed to realize his promises.

Bourassa regained much of his influence when he participated in the first Congrès de la Langue française in June, which had been organized by $\mathrm{M}^{\text {sgr }}$ Paul-Eugène Roy, the auxiliary bishop of Quebec, who was devoted to defence of the French language and of national traditions, and to the grouping in a single organization of all the Catholic social movements of the province. This was a national gathering with political implications, since delegations of all the out-lying French groups attended and argued their causes. Bourassa, just returned from travels in Europe, once again eloquently hymned the French tradition and the French language, maintaining the moral right of the French Canadians to use their mother tongue from Halifax to Vancouver. Though the Congress took no significant action, it supplied evidence of the vitality of French Canada by a vast rally of its forces.

Bourassa carried on his war against all the various naval proposals; and he succeeded in defeating the schemes for Canadian contribution of three dreadnaughts or a money contribution, as be had defeated the plan for a Canadian Navy. But increasingly his energy went into the conflict over education rights in Manitoba and Ontario. His followers in Montreal formed the Ligue des droits du Français, which was a more nationalist version of the Société du Parler français. Their programme received support from both the hierarchy and the lower clergy. Though Bourassa kept in touch with the rest of Canada by frequent speaking trips [p. 157] and study of the English-Canadian 
press, his followers became more and more provincial and self-centered in their outlook. As the First World War drew near, Quebec looked westward to its persecuted compatriots rather than towards Europe, while a narrow nationalism predominated in French Canada.

At the outset, sympathy for French and Belgium swept French Canada into unity with English Canada on the war. Laurier and Archbishop Bruchési issued appeals for patriotism, and there was little questioning of their stand, except by Armand Lavergne. But few in Quebec except the French-Canadian leaders were really concerned about world affairs. The anti-imperialist agitation had aroused the traditional folk-hatred of England. Quebec's rank and file failed to share the authentic, feeling for France felt by their leaders who knew and loved France. The people had been exposed too long to ecclesiastical warnings against irreligious and anti-clerical modern France, particularly stressed by the French religious congregations which had taken refuge in Quebec from the anti-clerical laws of 1900-01. The people of Quebec were more concerned with the struggle for educational rights in Ontario than the struggle in Europe. There was no real French leader at Ottawa to offset Sir Sam Hughes' blindness to French-Canadian susceptibilities. The old local militia units were broken up, and the authorities refused to approve proposals to form separate French-Canadian units. Because of the strong French-Canadian group consciousness, the prospect of being thrown into an English-speaking environment had more terrors than the dreadful fates conjured up by patriotic orators as apt to befall Quebec if French Canada failed to do its part.

Bourassa, who had been in Europe at the outbreak of the War, soon objected to the uncritical pro-war enthusiasm which swept Canada, particularly since so much of it came from his traditional rivals. He called for limited participation, based upon a sober estimate of Canada's capacities. In an examination of the English "White Book» on the origins of the War, he stressed that self-interest had guided Britain, and should guide Canada in its course. He was called a traitor by the English press for his stand, and the organs of the hierarchy refuted his thesis in fervently loyalist style. But on the whole, popular French-Canadian opinion tended to support him, as the early patriotic enthusiasm wore off and English [p 158] Canadian scorn for Quebec's enlistment record and Quebec's indignation about the Ontario school question had their effect. Bourassa was mobbed in Ottawa when he attempted to address a public meeting in December 1914. Handbills were circulated calling him the "arch traitor of Canada» and urging that «the skull of rebellion must be smashed ». His own language was not much calmer, for at this period he wrote in Le Devoir : "In the name of religion, liberty, and faithfulness to the British flag, the French Canadians are enjoined to go fight the Prussians of Europe. Shall we let the Prussians of Ontario impose their domination like masters, in the very heart of the Canadian Confederation, under the shelter of the British flag and British institutions? »

By the beginning of 1915 Quebec was far more concerned with Ontario than with Europe. Political scandals in the Militia Department, discrimination against French-Canadian officers, and the bugbear of conscription, which 
Bourassa had already predicted by December 1914, had cooled off French Canada's interest in the War. As Canada's limited supply of manpower felt the pinch, between the increasing need for recruits and the demands of a rapidly expanding munitions industry, conscription was frequently urged. The Nationalists were infuriated when two leading English-Canadian industrialists in Montreal announced that they would not employ men of military age, who should be at the front. Napoléon Garceau protested against such intimidation : " If military service should be obligatory, let it be so for all, rich as well as poor, but under laws passed by the parliament of the country, and not because of the authority or power that money may give to certain personages. » The situation grew steadily more bitter, with anti-conscription demonstrations ; the application of censorship; and calls for the internment of "von Bourassa. » Borden was too wise to make a martyr of Bourassa; and Laurier, Rodolphe Lemieux, and other Liberal leaders vigorously urged voluntary enlistment as the best means to avoid conscription. Bourassa supported Pope Benedict XV's call for peace. The hierarchy became alarmed by the evident conversion of the lower clergy to Bourassa-ism and by its opposition to conscription. Olivar Asselin, after quarreling violently with the loyalist hierarchy on their pro-war stand and participating in anti-conscription movements, finally decided to enlist in 1916. Sir Sam Hughes [p. 159] finally gave some French-Canadian leaders an opportunity to raise French units, but the decision came too late. Quebec was at swordspoints with Ontario, rather than with Germany. Under pressure from both camps, the political truce accepted by Liberals and Conservatives at the outbreak of the War broke down.

As losses mounted in Europe in 1916, the political temperature mounted at home. Bourassa's reasoned attacks on government policy were echoed in far more emotional and uncritical fashion by an ever-wider circle in French Canada. National Registration was followed by conscription in July 1917. It cost the government the support of French Canada, which was left without any representation in the new Union government. Following the "Khaki Election » late in 1917, the Quebec legislature debated a motion by J.-N. Francœur that Quebec would be disposed to accept the breaking of the Confederation Pact of 1867, if in the other provinces it is believed that she is an obstacle to the union, progress, and development of Canada. » The debate provided a safety valve for Quebec's pent-up resentment at English-Canadian attacks. It was clear that Quebec had no serious desire to quit Confederation, but had been driven to consider it by English Canada's intransigent and insulting attitude.

Bourassa, depressed by the breakdown of Confederation and his wife's death, took little part in public life in the early months of 1918. The new idol of the young French-Canadian nationalists was Abbé Lionel Groulx, the founder of the A.C.J.C., who was expounding Canadian history in new and fervidly French-Canadian terms at the Université de Montréal. Passive resistance to national registration and conscription prevailed until the antidraft riots at the end of March 1918 in Quebec City, which most unfortunately, were put down by Toronto troops. A Quebec which had a deep respect for law and order despite its tendency to verbal violence was horrified by the blood then shed, and the public temperature dropped notably. The government 
adopted a policy of conciliation rather than coercion until the end of the war. English Canada lost most of its bitterness against French Canada as time passed, but French Canada never forgot the troubles of 1917-18, which nourished a new nationalist movement which was distinctly provincial and sometimes separatist, as Bourassa's nationalism had never been.

\section{[p. 160]}

Sir Robert Borden was conscious of the necessity of winning Quebec from its isolation by French-Canadian representation in the cabinet, and made overture to Sir Lomer Gouin, who was the titular leader of French Canada after Laurier's death in 1919. These failed at first, despite Borden's offer to resign if that step would ease the situation. Later in the year Borden's decision to resign because of his health was announced, but he was induced to remain in office until July 1920. In the years that followed Borden came to occupy the position of Canada's elder statesman, and by his lectures and writings on constitutional problems did much to formulate the new English-Canadian nationalism which he had helped to crystallize during the War years, despite his imperialist beginnings. In the end, he led in the realization of many of Bourassa's ideals for Canada. With the slow post-war development of EnglishCanadian nationalism, French Canadians were left less isolated politically, if the cleavage between the races still remained deep.

Quebec's wartime retreat into a narrow provincialism predisposed French Canada towards a more rigid isolationism in the post-war world than otherwise probably would have prevailed. The years between 1920 and 1939 were characterized by Canada's increasing involvement in international affairs, and its gradual shift from economic and political dependence upon Britain to a greater economic but lesser political dependence upon the United States. Both historical processes represented a threat to French-Canadian cultural survival, and hence reinforced Quebec's tendency to turn inward upon itself, which did not yield to the new internationalism until the late 1930's. French Canada's long conditioning against imperialism resulted in some years of post-war battling against a British political imperialism that was fast dying, while the lack of an economic point of view among most of the humanistically educated élite long blinded French-Canadian spokesmen to the new American economic influences which offered perhaps an even greater challenge to a minority determined to maintain its separate way of life. The threat was finally recognized as a result of the simultaneous American cultural penetration of Quebec, which was vigorously fought by the élite and generally welcomed by the people, to whom industrialization brought a higher standard of living than they had previously known. Towards the end of the period, American isolationism reinforced traditional French [p. 161] Canadian isolationism, as the younger nationalist leaders adopted Bourassa's tactics of quoting British and American public figures to the embarrassment of Canada's own leaders. These figures were themselves torn between the pull of a new EnglishCanadian nationalism which went largely unrecognized in a Quebec turned in upon itself, and the sometimes conflicting pressures from London and Washington. 
Sir Lomer Gouin retired as premier in 1920, and his successor, LouisAlexandre Taschereau, announced that he would follow the same policy as his predecessor had done for fifteen years : continued development of Quebec's natural resources and wealth, and the maintenance of the province as a " sanctuary of tolerance ». In the following year Gouin accepted a federal nomination, and received Conservative as well as Liberal support. Arthur Meighen's government was roundly defeated, with all his French-Canadian ministers losing their seats, while the Laurier Liberals Gouin, Lemieux, Lapointe, Béland, and Bureau won large majorities. With the new Mackenzie King Liberal Government dependent upon a bloc of 65 Quebec seats, Quebec received a lion's share, after her virtual exclusion from the federal cabinet since 1917. King's instance on Canadian autonomy in various post-war questions continued the reconciliation of Quebec to Confederation. From time to time, as wartime industrial expansion in Quebec resumed after the post-war depression, Premier Taschereau was attacked for administering the province for the benefit of «foreign trusts. " Over $\$ 300$ million of English-Canadian and American capital was invested in the province from 1925-37, mostly in pulp and power developments. Taschereau stated his policy thus in 1927: " The way of success in this province lies in keeping our material resources at home, so that we can develop them here. The key of success is electrical power, so that those who wish to create industries will come here. Such a policy is eminently Canadian and national. »

This policy encountered growing opposition as the belated arrival of the industrial revolution upset Quebec's traditional way of life. With capital and management largely in English-speaking hands, the ethnic feeling aroused by the conscription crisis was heightened by post-war economic developments. The French Canadians were left behind in business and industry, for they lacked both capital, [p. 162] and training in economics, engineering, and the physical sciences. They found themselves no longer masters in their own house, and they blamed their situation on ethnic discrimination rather than on lack of qualifications. The newly industrialized and urbanized habitant blamed the trials of his new life not on the industrial system, but on the fact that is was controlled and imposed by aliens. This economic invasion by cultural aliens produced an economic nationalism. After 1920 the nationalist press came to be characterized more and more by protests against « foreign exploitation of our resources », and agitation in favour of French-Canadian support of FrenchCanadian business and industry. The old opposition to English Canadians was heightened, while a new anti-Americanism grew up. Anti-semitism also increased. French Canada was searching for scapegoats as a result of radical changes which had been imposed upon it from outside, rather than developed from within. A host of irritations arising from the friction of two very different mentalities served to keep ethnic feeling alive.

The French Canadians found their minority status intensified, for they were now arrayed not only against an English-Canadian majority which had imposed its will upon the French Canadians during the war years, but also in opposition to the industrial way of life which prevailed in English-speaking North America. The French Canadians sought to maintain their own « Latin » way of life against an «Anglo-Saxon » materialist one which was favoured by 
great odds. This situation furthered the development of the racism involved in nationalist theories imported from Europe by Abbé Lionel Groulx and other nationalist leaders. Nationalist thinking was increasingly economic rather than political, though the dream of a separate French-Canadian state, "Laurentia », haunted some hot-headed minds. On the other hand, a group of deeply patriotic French Canadians sought to meet the challenge of the times, not by dissent or rejection, but by modifying their traditional culture to meet the new conditions brought about by the industrialization of Quebec. From 1917 to 1928 Quebec turned in upon itself ; from 1932 onwards it looked more abroad, still deeply isolationist, though more and more conscious that its difficulties were not unique. The great depression of 1929, from which Canada did not really rally until the war boom began in 1939, increased the economic emphasis of French-Canadian [p. 163] nationalism and sharpened the ethnic friction. Depression, like war, has always set French and English Canadians at odds, and since French labour and indeed capital, was harder hit than English management and capital after 1929, and the French standard of living had a smaller margin, the result was the development of movements of social discontent in the 1930 's, though the vigorous nationalism of the early twenties had melted away as prosperity increased during the boomdays of the 1920's.

Unemployment reached its peak in Quebec in 1932. It was not surprising that early the following year the L'Action française movement was revived as L'Action nationale, with an aggressive rather than a defensive programme. Young French-Canadians adhered to it enthusiastically, for political action was still open to them, though the depression barred them from normal careers and economic opportunities. They were concerned that the French Canadians were becoming a proletarian people. They demanded that the natural resources of the province should not be administered so as to compromise the FrenchCanadian heritage, while «foreign capitalists » imposed upon them «the worst of dictatorships » and ostracized their engineers and technicians, leaving open to French Canadians only the roles of labourers and servants. They echoed the traditional nationalist positions on the rights of the French language and against discrimination in federal government service. Their Manifesto of the young generation warned : "We ask today what we shall exact tomorrow. » The Jeune-Canada movement gained impetus during the winters of 1932-33 and 1933-34. It was contemptuous of most of the elder statesmen, with the exception of Édouard Montpetit and Abbé Groulx. It was particularly bitter about the politicians, whom it called « the eternal enemies of our race. " The leaders of Les Jeune-Canada succeeded to posts of command in the nationalist movement. They campaigned against the trusts, against communism; they called for a chef to make a new French Canada, as Mussolini had remade Italy and Dolfuss had remade Austria. They were more or less openly separatists. Thus efforts at political action ended with experienced politicians exploiting youthful idealism quite as cynically as the most socially irresponsible trustard might have done natural resources. The movement probably reached its height in 1937, when Abbé Groulx proclaimed at the second Congrès de la Langue [p. 164] française : « Our sole legitimate and imperative destiny can only be this: to constitute in America, in the greatest autonomy possible, this political and spiritual reality ... a Catholic and 
French State ", to which he added, "Whether or not one wishes it, we shall have our French State. This brought about a split between separatists and antiseparatists ; and Bishop Yelle, speaking of the French Canadians of the West on the same occasion, said : "We hear separatism for the Province of Quebec seriously spoken of, we see in it not words of salvation but words of discouragement and defeatism. »

When André Laurendeau became director of L'Action nationale in September 1937, after two years' first-hand contact with the rising tide of Fascism in Europe, he condemned the racism he found upon his return to Canada. He observed with justice - « French Canadians always applaud more willingly anathemas against the extreme left than anethemas against the extreme right. We are too often among those who think, according to the harsh formula of La Vie intellectuelle, that God is on the right. » He warned of the dangerous alliances that might be made in the name of anti-Communism, arguing that anti-Communism and anti-Fascism were mere distractions from the real problems of Quebec, since only a handful really supported Communism and Fascism. He blamed the fascistoid groups in Quebec, which had aroused so much outside comment, on a decreasing lack of faith in popular government. Archbishop Gauthier of Montreal, in condemning Communism in March 1938, also warned that Adrien Arcand's National Social Christian party advanced a watered German Nazism. Then, as the war clouds piled up in Europe, nationalism turned into the traditional channel of anti-imperialism and isolationism, leaving these theoretical problems unsettled.

One result of the second World War, which stepped up the industrialization of Quebec, was to give nationalism a social bent, which marked quite as much of a development as the shift from the political to the economic field after the first World War. That evolution has not yet ended, but it may be far more fruitful, since another effect of the War was to restore to French-Canadian nationalism the internationalism it had had lacked since Bourassa's heyday.

\section{H. Mason WADE}




\title{
COMMENTAIRES
}

\author{
Lorenzo Paré
}

$\underline{\text { Retour à la table des matières }}$

L'essai de M. Wade récapitule de façon à la fois objective et impressionnante les courants et les événements politiques qui ont marqué la vie du Canada français durant les quarante premières années de ce siècle. Une telle synthèse reconstitue, dans l'intégrité de son ensemble, le casse-tête chinois dont nous sommes les observateurs distraits, sinon souvent inconscients. Mais comme cette synthèse pose des problèmes particulièrement aigus pour notre conscience nationale, il est essentiel de vérifier les prémisses qui lui donnent son sens et sa valeur.

Une des principales questions que soulève l'étude de $M$. Wade est de nous faire demander s'il est bien vrai que «French Canada's political history has always been oriented by the principles of cultural survival and recognition of its rights » ? Sans aucun doute. Mais on peut en dire autant de n'importe quel peuple de la terre. Est-il bien exact d'affirmer que notre évolution politique se concrétise dans ce qu'on appelle «le nationalisme», avec des phases antiimpérialistes, politiques, économiques et puis sociales ? À cet énoncé du problème, je me permets de répondre à la fois « oui » et « non ».

« Oui », si l'on s'en tient au contenu anecdotique de l'histoire. «Non », si on pèse sa substance. Le fracas des mouvements de jeunesse peut apparaître, à la faveur de chaque crise, comme une explosion nationaliste ou séparatiste. M. Wade en a cité des exemples. Mais ceux qu'on a appelés les " Jeunes Canada » ou même "fascistes » dans le Québec, s'appelleraient ailleurs des America Firsters, des affidés de l'Order of Orange ou des Klans. L'antisémitisme d'un Arcand, dont M. Wade a parlé, va rejoindre celui d'un McCarthy. Mais un Arcand n'a jamais été élu sénateur par le peuple du Québec ! Des minorités vocales dans la masse d'un peuple ! Le racisme n'a jamais été importé chez les Canadiens français.

En fait, les Canadiens français ne constituent pas un phénomène unique. Sans doute, la rapidité de l'industrialisation dans une société cohérente comme la nôtre offre un champ d'expériences remarquablement circonscrit qui se prête naturellement à des analyses d'ensemble comme celles du présent volume. Mais les effets de cette industrialisation et les problèmes qui en découlent [ $p$. 166] ne sont pas particuliers aux Canadiens français : ils sont les mêmes dans l'univers entier. Il en résulte que ce qu'on appelle le «nationalisme canadien- 
français " n'est que la lutte commune à tous les citoyens du monde pour l'individualité et pour leurs intérêts collectifs. Ce qu'on appelle « nationalisme » chez une minorité entourée de dangers n'est que l'exercice normal de la conscience politique chez les citoyens de n'importe quel autre pays du monde.

Sinon, comment pourrait-on expliquer qu'aucun parti « nationaliste » n'ait jamais réussi à survivre chez les Canadiens français, demeurés plus entêtés que tout autre Canadien peut-être dans le «rouge» ou le «bleu»? Les pétarades isolées ne peuvent pas avoir soutenu le moteur de notre évolution politique. Car s'il est vrai que le nationalisme fut le moteur de la vie politique chez nous, notre évolution se résorbe dans une série d'échecs.

Or, M. Wade a admirablement illustré lui-même que la politique canadienne-française fut loin d'être un échec, en analysant l'histoire aussi bien que les anecdotes de notre évolution politique. Avec une générosité que nous aimons à qualifier de clairvoyante, il a signalé l'influence canadienne-française qui, à travers Laurier, a formulé le nouvel idéal du Commonwealth et qui, à travers l'ancien impérialiste Borden, a précipité l'exercice d'une souveraineté canadienne avant d'oser, sous le premier ministre actuel, le rêve d'une communauté de l'Atlantique-nord. Pendant deux siècles, les Canadiens français ont été le ferment qui a précipité la maturité de l'Empire britannique jusqu'à l'association libre du Commonwealth, qui pousse aujourd'hui à l'extension de son idéal dans la communauté de l'Atlantique afin de reconstituer par ces progrès fragmentaire l'unité elle-même de l'humanité.

Le nationalisme canadien-français n'a donc été un repliement sur soi et un isolationnisme que sous une menace extérieure et accidentelle. Le nationalisme chez nous est un réflexe de défense. Ce n'est pas un mode de vie. C'est un véhicule qui sert, à l'occasion, pour contenir et répandre la pensée canadienne-française. Il ne faut pas confondre le véhicule avec son contenu. C'est un filet d'eau, un ruisseau, - humble mais tenace -, qui se confond toujours dans le grand fleuve de la politique canadienne et désormais, dans l'océan humain.

Selon la thèse de M. Wade, les Canadiens français en seraient arrivés aujourd'hui à la phase du nationalisme social. Encore [p. 167] là, il faut distinguer et répondre à la fois «oui» et «non» Oui, peut-être, si l'on considère les éclats sans lendemains que pourrait provoquer une situation comme celle de Montréal, par exemple, ce monstre industriel qui pompe un tiers du sang français et qui réduit les fils des pionniers à la servitude des prolétaires. Non, certes, si on envisage le problème dans l'ensemble de sa réalité, dans les buts à atteindre et dans les moyens d'y parvenir. La prolétarisation des travailleurs dans une ville comme Montréal n'est pas, non plus, un phénomène particulier au Québec. Elle se retrouve aussi bien à Toronto qu'à Détroit. Nos Syndicats catholiques et nationaux le comprennent. Leur collaboration avec les autres groupements de travailleurs est commencée. La solution qu'ils proposent est celle de l'intégration des classes, et non leur lutte ; celle de la dignité individuelle et non sa mécanisation. Et cette solution, parce qu'elle est humaine, c'est-à-dire universelle, finira par triompher. 
M. Wade a trouvé chez nous une autre sorte de nationalisme qu'il appelle le nationalisme «messianique » et il cite à ce sujet une déclaration de $\mathrm{M}^{\mathrm{gr}}$ L.A. Pâquet, à la fête de la Saint-Jean-Baptiste, en 1902. Voici cette citation de $\mathrm{M}^{\text {gr }}$ Pâquet : " Our mission is less to manipulate capital than to change ideas ; it consists less in lighting the fires of factories than to maintain and to make shine afar the luminous fire of religion and thought. " Le commentaire du conférencier fut le suivant: "This sermon was a classic example of the messianic nationalism derived from Bossuet and de Maistre, which was to become dominant in later years, tinged with more than a suspicion of sour grapes. » Cet idéal demeure! Quand on dit, comme M. Wade, que c'est l'expression d'un "messianisme nationaliste», ce n'est pas dans un sens péjoratif. Ce messianisme n'est-il pas l'obligation formelle de tous les chrétiens?

Les Canadiens français, avec leurs faiblesses et leurs fautes, font tout simplement de leur mieux pour ne pas enfouir le «talent» qui leur a été confié. Ils sont parmi les premiers peuples missionnaires de la terre. Ils ont le droit de communiquer eux aussi, sans violence mais avec ténacité, leur conception de la vie. Car cette conception de la vie qu'ils ont n'est pas, après tout, tellement différente de celles qu'entretiennent tous les autres hommes.

Lorenzo PARÉ 
[p. 169]

\title{
CHAPITRE VIII
}

\author{
LE SYSTÈME SCOLAIRE
}

\section{Léon Lortie}

$\underline{\text { Retour à la table des matières }}$

Les gens de ma génération, surtout ceux qui ont consacré leur vie à l'enseignement, auront vu se transformer le système scolaire du Québec sous la poussée de notre « révolution » industrielle. Cette évolution, qui affecte plus spécialement chacun de ses degrés, n'a pas encore modifié sensiblement la structure essentielle du système quoique l'on puisse discerner depuis un certain temps les symptômes d'une crise imminente. Tel qu'il subsiste encore, ce système est fait de pièces disjointes et il correspond à l'état d'esprit qui régnait lorsqu'il est né, peu après les troubles de 1837, sous le régime de l'Acte d'union des deux Canadas. D'une part, il manifeste une certaine méfiance envers l'État, dont on craignait l'ingérence et, d'autre part, il affirme un particularisme fort prononcé. La question se pose de savoir s'il peut longtemps subsister sous la forme confuse que nous décrirons.

La méfiance envers l'État se traduit d'abord en ce qu'on n'a voulu lui confier que l'enseignement élémentaire jugé indispensable à l'ensemble de la population. Dans ses Lettres sur l'éducation, publiées en 1838, Jean-Baptiste Meilleur proposait un vaste réseau d'écoles primaires dont l'État devait assurer la bonne administration financière et pédagogique. Mais le futur surintendant de l'éducation au Bas-Canada ne voulait pas qu'on soumît les collèges classiques à la régie de l'organisme officiel. Ils avaient, disait-il, donné la preuve de leur excellence et comme ils étaient bien administrés par le clergé, il ne convenait pas de les assujettir à un contrôle qu'on soupçonnait hostile. La surintendance des écoles fut d'abord une fonction dont le titulaire était responsable au pouvoir exécutif et, après la Confédération, Québec eut même un ministère de l'Instruction publique. Mais dès 1875 le Conseil de l'Instruction publique remplaçait ce ministère. La composition et les attributions du Conseil sont de nature à satisfaire aux besoins des deux principaux groupes ethniques et religieux de la population.

[p. 170] 
Le Conseil est divisé en deux comités, l'un catholique, l'autre, protestant. Il est présidé par un surintendant nommé par le Conseil exécutif et qui a les attributions d'un sous-ministre dans les cadres du Secrétariat provincial. Le surintendant sert d'intermédiaire entre le Conseil de l'Instruction publique et le Secrétaire de la province lequel, au sein du cabinet et devant les Chambres, parle au nom du Conseil. Le Comité catholique est formé de tous les archevêques, évêques et vicaires apostoliques de la province et d'un nombre égal de laïcs catholiques nommés par le Conseil exécutif et il est présidé par le surintendant. Les attributions du Conseil de l'Instruction publique sont restreintes à ce qui concerne l'enseignement primaire et les écoles normales mais, dans ce domaine, il a la mission de règlementer sur les programmes, les manuels, la compétence des maîtres, les examens et les diplômes élémentaires et d'écoles normales. On peut dire que cette conception bien particulière reconnaît l'intérêt et les droits respectifs de l'Église et de l'État en matière d'éducation. Quant aux parents, qui sont aussi directement intéressés en la matière, c'est au niveau local, par l'élection des commissaires d'écoles, qu'ils peuvent, sauf à Québec et à Montréal, faire entendre leur voix.

Un tel organisme, d'où sont exclus les collèges classiques, les universités et les écoles techniques, reflète bien l'esprit particulariste qui l'a créé. Il y a plus encore, car le Conseil ne possède pas le monopole de l'enseignement primaire. Rien n'empêche, aux termes de la loi, l'établissement d'écoles élémentaires ou primaires totalement indépendantes de la juridiction du Conseil de l'instruction publique. Il est vrai que ces écoles ne bénéficient pas des avantages qu'offre un système officiellement reconnu, mais la réputation qu'elles peuvent acquérir par la valeur de leurs maîtres et l'excellence de leurs programmes fait que beaucoup de gens les préfèrent, pour l'instruction de leurs enfants, aux écoles publiques. C'est ainsi qu'un dixième de la population scolaire totale de la province de Québec fréquente quelque 520 écoles privées qui comprennent des maternelles, des jardins d'enfants, des couvents et des collèges, dirigés presque tous par des communautés religieuses. Ajoutons enfin que plusieurs ministères administrent directement des écoles de toutes sortes. Le Secrétariat provincial s'occupe des écoles du soir, de l'École des Hautes études commerciales de Montréal, des Écoles des beaux-arts, du Conservatoire de [p. 171] musique et d'art dramatique; le ministère du Bien-être social et de la Jeunesse dirige les écoles techniques, les écoles d'arts et métiers, des écoles spécialisées telles que l'École du meuble et l'École des arts graphiques, des cours par correspondance et des écoles de protection de la jeunesse; le ministère de l'Agriculture administre les écoles moyennes et régionales d'agriculture, l'École de laiterie et l'École de médecine vétérinaire en même temps qu'il subventionne les écoles supérieures d'agriculture; les ministères du Travail, des Terres et Forêts, des Mines, de la Chasse et des Pêcheries et de la Santé ont aussi des écoles qu'ils administrent ou des cours qu'ils subventionnent.

Sous cette diversité se retrouvent néanmoins les quatre éléments fondamentaux d'un système d'instruction publique: les enseignements primaire, secondaire, technique et supérieur. Mais comme aucun principe d'unité n'existe pour intégrer leur action et comme, par ailleurs, les préjugés populaires et le snobisme les opposent souvent les uns aux autres, chacun de 
ces éléments tend à vivre d'une vie autonome. La confusion s'accroît à mesure que chaque élément se développe et envahit le champ du voisin. Des ensembles plus solidement agencés ont eu du mal à s'adapter aux effets de la révolution industrielle. Le manque de cohésion de l'assemblage québécois expose chacune des parties à soutenir seule le choc des événements. Il est donc intéressant de noter de quelle façon ces entités repliées sur elles-mêmes ont voulu réagir contre l'ordre nouveau ou ont tenté de s'y conformer. Une telle analyse nous permettra de mettre aussi en relief les conflits nés de la diversité des attitudes prises indépendamment par chacun des intéressés.

\section{1. ÉVOLUTION DE L'ENSEIGNEMENT PRIMAIRE}

Parce qu'il s'adresse à la masse de la population et que tous les enfants doivent y passer, l'enseignement primaire fut le premier touché par la montée soudaine de l'industrialisation du Québec, aux environs de 1915. Montréal, de par son rôle de métropole, fut le théâtre de presque tous les événements importants qui résultèrent de ce phénomène. Sa population grandit à vue d'œil, enflée par l'afflux des familles rurales qui venaient travailler dans ses usines, ainsi que par l'annexion de nombreuses municipalités incapables de faire face aux charges financières dues à une trop ra-[p. 172] pide expansion. Le premier résultat de cette croissance subite fut la centralisation des quelque quarante commissions scolaires éparses sur le territoire montréalais. La centralisation administrative rendit possible la construction d'une centaine d'écoles en moins de dix ans. Pour fixer les idées à ce sujet, remarquons qu'en 1915, la Commission des Écoles catholiques de Montréal étendait sa juridiction sur 61 écoles (dont 37 lui appartenaient) fréquentées par 29,256 enfants ; dix ans plus tard, elle possédait 194 écoles que fréquentaient 96,000 enfants.

À cette centralisation administrative dont nous venons d'indiquer l'importance et qui se poursuivit de 1917 à 1928, s'ajoute une réforme pédagogique instaurée vers le même temps. La plupart des écoles n'avaient jusque-là que quatre classes et on y enseignait toutes les matières du cours primaire qui se terminait à la sixième année. Presque tous les enfants quittaient l'école après la quatrième année. Pour ceux qui désiraient poursuivre leurs études au-delà de la sixième année à Montréal, l'école du Plateau offrait aux garçons, et l'académie Marchand aux petites filles, des cours complémentaires de deux ans que couronnait un diplôme spécial. La réforme de 1923 s'inspira des programmes de l'instruction publique de France : elle établit un cours élémentaire de six ans réparti en six classes (puis en sept, lorsque l'année préparatoire devint la première année du cours), un cours complémentaire de deux ans, chacun des cycles étant sanctionné par un brevet ou certificat d'études. $\mathrm{Au}$ cours complémentaire on prévoyait un commencement d'orientation : industrielle, commerciale, agricole ou ménagère, selon le sexe des enfants et le milieu qu'ils habitaient. Financé entièrement par l'impôt scolaire, l'enseignement était gratuit et, malgré de vives oppositions, une certaine uniformité des manuels scolaires fut imposée. Un trait typique de 
l'adaptation du système aux temps nouveaux se manifestait dans le fait que le petit Montréalais, dont on sait que les parents aiment à changer de logement le $1^{\mathrm{er}}$ mai, pouvait trouver, dans la nouvelle école qu'il fréquentait, la suite de la leçon qu'il avait suivie la veille dans l'école d'un autre quartier. L'enseignement était organisé et comparable d'une école à une autre. Il ne restait plus, pour être à la page, que de décréter l'école obligatoire mais des oppositions marquées et agissantes retardèrent jusqu'en 1943 l'adoption de cette mesure, sous la forme d'une loi dite « de la fréquentation obligatoire des écoles $»$.

\section{[p. 173]}

Plus encore que cette législation, la fondation de l'enseignement primaire supérieur nous paraît le phénomène important dans l'évolution de l'école primaire. Depuis 1911, la Commission des Écoles catholiques de Montréal s'était fait autoriser à créer des écoles primaires supérieures mais ce n'est que dix ans plus tard qu'elle se prévalut de cette prérogative. Sous la pression exercée alors par $\mathrm{M}^{\mathrm{gr}}$ Philippe Perrier, M. J.-P. Labarre et M. E.-C. Piédalue, on ouvrit timidement une première classe de $10^{\mathrm{e}}$ année à l'école du Plateau. Devant le succès remporté, une deuxième classe fut ouverte solennellement, l'année suivante, à l'école Saint-Louis.

La création de l'enseignement primaire supérieur qui, de Montréal, se répandit dans toutes les villes importantes du Québec, est un phénomène capital car elle marque un élargissement de la pensée des éducateurs, une rupture des cadres traditionnels et une adaptation aux circonstances qui n'est pas loin de signifier la fin de l'isolement dans lequel on avait toujours tenu à se maintenir. Les pionniers du cours primaire supérieur se rendaient compte qu'un très grand nombre d'enfants doués étaient privés d'une instruction complète parce qu'ils ne pouvaient fréquenter des institutions privées, classiques, scientifiques ou commerciales, dont leurs parents ne pouvaient faire les frais. Incapables de se prévaloir d'avantages trop onéreux, tous ces talents restaient en friche et devaient se contenter d'emplois subalternes alors que, mieux instruits, ils eussent pu prétendre à un avenir plus reluisant. Le cours primaire supérieur démocratisait et mettait à la portée de tous une instruction jusque-là réservée à ceux que favorisait la fortune ou que secourait un bienfaiteur.

Prolongement du cours primaire, le nouvel enseignement ne se pose pas, au début, comme un concurrent du cours secondaire classique mais il était inévitable que son succès dût le mettre un jour en compétition avec ce dernier. À la fin des études primaires le choix s'impose désormais entre le collège dont le cours conduit, par le baccalauréat, aux professions libérales, et le cours primaire supérieur qui, dans la pensée de plusieurs, présente un programme plus pratique parce qu'il ne comporte ni grec ni latin. En quoi, alors, ce cours se distingue-t-il de celui des high-schools ? En principe, les deux cours sont parallèles et c'est sans doute cette pensée qui a le plus influencé les champions des écoles nouvelles. Ils [p. 174] sentaient que, pour lutter à armes égales avec les jeunes gens de langue anglaise, les jeunes de langue française devaient posséder une égale instruction. Tant que le Québec avait vécu sous un régime d'économie rurale et presque patriarcale, on avait pu se contenter d'un 
minimum d'instruction et compter, pour réussir dans les affaires, sur les seules qualités personnelles. Cela pouvait, à la rigueur, satisfaire encore les besoins limités du petit commerce entre gens de même origine et de formation semblable. Ce n'était plus possible dans un monde où le commerce et l'industrie imposaient la règle, sinon le règne, de la compétence, du rendement et de la spécialisation. Par le cours primaire supérieur, le système scolaire québécois s'alignait sur une devise étrangère que lui proposait et imposait le voisinage des écoles anglaises. Il était d'autant plus nécessaire de franchir ce pas important que les Catholiques de langue anglaise réclamaient un programme en tout point comparable à celui des high-schools afin de soutenir la concurrence directe des jeunes Anglais protestants. Munis de cet enseignement, ils pouvaient aussi être admis directement dans les universités de langue anglaise. On se demanda pourquoi les diplômés des écoles primaires supérieures ne pourraient pas jouir d'un semblable avantage dans les universités de langue française. Si paradoxal que cela puisse paraître, ces jeunes gens, fils des premiers habitants du pays, se trouvaient dans une situation inférieure à celle des fils d'émigrants de fraîche date. Pour accéder à l'université, Pierre Tremblay devait d'abord passer huit années dans un collège classique et ses parents devaient débourser de dix à vingt dollars par mois pour l'y maintenir jusqu'à l'âge de vingt et un ans afin de l'amener au seuil de l'université d'où il ne devait sortir que quatre ou cinq ans plus tard. De leur côté, Hyman Rosenberg et Ladislas Bromilow n'avaient qu'à passer quatre ans dans un high-school, où leurs parents n'avaient presque aucun frais de scolarité à acquitter, pour pouvoir s'inscrire à McGill d'où ils sortaient quatre ans plus tard, à vingt-deux ans, munis d'un baccalauréat qui leur ouvrait une carrière. Si le Canadien d'expression française voulait soutenir avec quelque chance de succès la concurrence créée par la révolution industrielle il était impérieux de lui ouvrir, au même âge et dans les mêmes conditions qu'à ses concurrents, les portes de certaines facultés universitaires dont les études ne sont pas régies par les exigences des corps professionnels.

[p. 175] De Montréal, qui seule présentait d'abord des conditions favorables à sa naissance et à son développement, l'enseignement primaire supérieur s'est répandu dans toutes les villes importantes et on l'a étendu aux jeunes filles. En certains endroits, on l'a coiffé d'une treizième année qui prépare directement les élèves aux facultés de sciences, de génie et de commerce. On le considère de plus en plus comme un véritable enseignement du second degré et il a fourni les preuves de son efficacité. Le Comité catholique du Conseil de l'instruction publique l'a bien compris lorsqu'il a voulu établir, avec une certaine lenteur, sans doute, un programme bien adapté aux besoins de la jeunesse qui doit y trouver, en même temps que des connaissances pratiques, une formation générale indispensable à ses études futures et au rôle qu'elle jouera bientôt dans la société. $\mathrm{Si}$ on procède lentement c'est que tout le problème de l'enseignement du second degré se trouve mis en question et que le Comité n'a aucune juridiction sur les collèges qui, seuls jusqu'ici, en ont assuré l'existence. Mais le problème est pressant et le Comité a nommé, en 1951, une commission spéciale chargée d'étudier la coordination de l'enseignement à tous les degrés. 


\section{RÉACTIONS DE L'ENSEIGNEMENT SECONDAIRE}

Ceci nous amène à parler de l'enseignement secondaire qui, dans l'ensemble, opposa une résistance foncière aux effets de l'industrialisation tout en paraissant s'adapter aux circonstances. Cela peut, au premier abord, sembler paradoxal mais si on se rappelle que la formule traditionnelle de l'enseignement secondaire québécois est celle du cours classique à base d'humanités gréco-latines et de philosophie, tel qu'il fut conçu dans les collèges des Jésuites à la fin de la Renaissance, on comprendra que les concessions faites à l'enseignement des sciences et la fondation d'externats classiques n'altèrent en rien la structure même du cours et les méthodes pédagogiques. Le but de ce cours, est la formation générale requise pour aborder plus tard l'étude de la théologie, du droit et de la médecine. Le cours, qui dure huit années, est partagé en deux cycles de quatre ans : les classes de grammaire, celles de lettres et de philosophie-sciences, ces dernières étant parfois désignées sous le nom de «cours universitaire » parce qu'il conduit immédiatement au baccalauréat. Dans l'esprit des maîtres, [p. 176] le cycle entier des études classiques est de nature secondaire, tant dans les matières au programme que dans les méthodes pédagogiques dont on se sert.

Les maîtres de l'enseignement secondaire classique ont surtout discerné, dans la marée montante de l'industrialisation, le spectre du matérialisme et de l'américanisation. Il fallait à tout prix résister à la menace qui pesait sur un peuple chrétien et y opposer l'humanisme et le spiritualisme les plus purs, seuls capables de blinder la jeunesse et de la prémunir contre ces périls. Envers et contre tous, on était sûr d'avoir raison et on applaudissait les déclarations des éducateurs américains qui déploraient la faillite des cours à option et qui remettaient en honneur l'étude des humanités.

En raison de cette attitude intransigeante, l'enseignement secondaire subit de durs assauts. Les griefs qu'on lui imputait peuvent se résumer à quelques chefs d'accusation : il était un monopole; il ne préparait pas ses élèves, en négligeant les sciences, aux études universitaires de plus en plus axées sur les sciences; il coûtait trop cher et durait trop longtemps pour être accessible à tous les jeunes gens qui pourraient l'aborder avec profit; il ne tenait pas suffisamment compte des aptitudes de sujets doués pour des études moins abstraites ; il était tellement différent de tout autre genre d'enseignement que les élèves qui devaient le quitter en cours de route ne pouvaient s'intégrer dans aucun autre cours du second degré.

Désireux de conserver l'intégrité du cours classique tout en s'adaptant à la situation nouvelle, les maîtres de l'enseignement classique firent d'abord quelques concessions dans l'enseignement des sciences. Ils reconnurent qu'on 
pouvait améliorer celui-ci, tant en quantité qu'en qualité. Ils allèrent même, il y a quelques années, jusqu'à adopter ce qu'ils avaient toujours considéré comme une erreur pédagogique : la bifurcation en vue d'une spécialisation. Il est vrai que l'option ne s'exerce que dans les deux dernières années du cours et que, de cette façon, l'unité gréco-latine est sauvegardée. Un observateur désintéressé peut s'étonner qu'on ait sacrifié l'essentiel, c'est-à-dire la philosophie, plutôt que de porter atteinte à ce qui est vraiment d'importance secondaire, l'étude des langues mortes. On vient enfin de reconnaître qu'à côté du cours classique traditionnel, il peut exister un enseignement secondaire sans grec, conservant le latin, et orienté vers l'étude des sciences.

\section{[p. 177]}

Une autre réponse aux besoins de l'heure fut la fondation des externats classiques. Leur établissement à Montréal suivit de près celui des écoles primaires supérieures. Ils étaient destinés à faciliter aux jeunes de condition modeste l'accès aux études classiques ainsi qu'à favoriser les vocations sacerdotales en attirant ceux qui, autrement, se seraient dirigés vers les écoles primaires supérieures. Le programme des externats est le même que celui des collèges classiques plus anciens.

S'il a si longtemps résisté aux assauts des forces issues de l'industrialisation, c'est qu'on a toujours considéré l'enseignement classique comme un tout homogène, de nature uniquement secondaire et destiné à former, par l'élimination de ceux qui ne peuvent s'y adapter, une élite professionnelle jalouse de la culture qu'elle croit posséder. Plusieurs se demandent aujourd'hui si on n'a pas exagéré; ils avancent de nombreuses raisons en faveur d'une conception différente. Sans vouloir discuter les buts et les objectifs de l'enseignement « secondaire », ce qui dépasserait les cadres de la présente étude, il convient de remarquer que, dans tous les pays, et quelle que soit la désignation du diplôme ou du certificat qui le sanctionne, cet enseignement se termine lorsque des élèves de dix-sept ou dix-huit ans ont fréquenté l'école durant douze ou treize ans. Cet âge et cette scolarité correspondent à peu près à la fin de la classe de belles-lettres (ou seconde), c'est-à-dire un an après la fin du premier cycle de quatre ans de nos collèges classiques. Plusieurs prétendent que, dans ces institutions, l'enseignement secondaire et ses méthodes pédagogiques devraient se terminer à ce moment. Nous n'avons pas à discuter le mérite de la question mais simplement à faire remarquer que, sous l'influence des conditions économiques imposées par l'industrialisation du Québec, on reconnaît à cette façon de voir de nombreux avantages. On pourrait ainsi, et c'est un point capital, coordonner les deux types d'enseignement secondaire qu'on a jusqu'ici opposés l'un à l'autre. Un même diplôme les sanctionnerait qui aurait une signification académique en même temps qu'une certaine valeur pratique. La seule préoccupation importante serait de maintenir dans le cours ainsi conçu le caractère de formation générale qui est, même si on l'a oublié en certains quartiers, le caractère essentiel de l'enseignement secondaire. Le cours classique n'y perdrait rien tandis que les élèves de l'enseignement primaire supérieur [p. 178] bénéficieraient désormais de ce qui est encore l'apanage d'une minorité. 
Quant au second cycle des études classiques, il est couronné par le baccalauréat qui est, dans notre pays comme partout, sauf en France, un grade universitaire qu'on décerne d'habitude à des jeunes de vingt à vingt-deux ans. Les quatre dernières années du cours classique sont d'ailleurs désignées sous le nom de cours universitaire et leurs programmes comme leurs examens sont régis par les Facultés des arts des universités Laval et de Montréal qui octroient le baccalauréat ès arts. Prétendre, comme on le fait encore, mais heureusement de moins en moins, que ces quatre années sont de l'enseignement «secondaire» est un non-sens pédagogique. C'est rabaisser notre baccalauréat au niveau d'un diplôme de matriculation. Cela importait peu lorsque nous vivions dans une économie fermée mais nous ne pouvons plus nous payer le luxe d'ignorer la valeur économique de quatre années d'études supérieures. Le climat industriel dans lequel nous vivons nous force à mieux comprendre la nature des études et à désigner d'une façon non équivoque ce qui est de nature secondaire et ce qui est universitaire.

$\mathrm{Vu}$ sous cet angle, l'enseignement des collèges classiques nous apparaît dans sa vraie perspective mais nous le voyons aussi coincé entre deux enseignements qui se sont adaptés aux exigences de l'heure. D'une part, le cours primaire supérieur lui fait concurrence et conduit maintenant ses diplômés au seuil des facultés des sciences, de génie et de commerce. Il s'efforce aussi d'obtenir pour ses diplômés l'entrée au cours universitaire des collèges classiques qui les conduira jusqu'aux facultés dont les portes ne s'ouvrent qu'aux bacheliers. De son côté, l'université régit les conditions d'obtention du baccalauréat et elle décerne, pour sanctionner des cours qui se donnent dans ses murs, des baccalauréats en sciences, en sciences appliquées (bientôt en commerce), à des étudiants qui lui viennent des écoles primaires supérieures. Il est à prévoir que, dans un avenir plus ou moins rapproché, cette initiative prendra plus d'ampleur et s'étendra à d'autres domaines spécialisés.

On serait porté à croire, en présence de tant d'empiètements, que le sort des collèges classiques est peu enviable. Au risque d'assombrir encore le tableau, il convient de faire voir un autre aspect de la situation qui est de nature à faire réfléchir. Notons d'abord qu'en dépit des dangers qui les menacent, l'enseignement classique n'a [p. 179] guère perdu de sa vogue. Le nombre des collèges augmente, sans cesse de même que la population scolaire qui les fréquente. Or, cet accroissement coïncide avec une diminution sensible du nombre des vocations sacerdotales en même temps qu'un besoin de plus en plus grand de prêtres pour le ministère paroissial. Assuré exclusivement par des prêtres, tout au moins jusqu'à ces dernières années, l'enseignement classique recourt maintenant aux services de maîtres laïcs. Mais alors qu'un prêtre reçoit une rémunération dérisoire pour son dévouement, et très souvent pour sa compétence, on ne peut exiger pareille abnégation de la part des laïcs et, malgré les vœux maintes fois exprimés par les autorités ecclésiastiques, on ne peut utiliser autant de ces maîtres qu'on le voudrait parce qu'on ne peut leur assurer le traitement qui convient à leurs besoins et à leur état. Qu'adviendra-til lorsque le déséquilibre s'accentuera davantage entre les exigences du ministère paroissial et celles d'un enseignement qu'il faudra donner à un nombre sans cesse croissant d'enfants avides de s'instruire et dont les parents trouvent que l'enseignement classique est déjà fort onéreux même dans les 
externats? Des éducateurs ecclésiastiques ont déjà signalé l'importance du fardeau financier qui menace de plus en plus les collèges classiques et ils ont même invité l'État à les aider davantage, même s'il leur faut, pour cela, abdiquer une partie de leur traditionnelle liberté.

La situation qu'a faite aux collèges classiques la révolution industrielle est donc vraiment angoissante. Ces institutions, qui ont rendu tant de services dans le passé, ne pourraient disparaître sans laisser un vide qui serait infiniment déplorable. Ils ont un rôle important à jouer dans notre économie tout autant que dans notre vie sociale et intellectuelle. Leur utilité nous apparaît d'autant plus nette que nous voyons de grandes universités américaines et canadiennes accueillir favorablement la formule des junior colleges, qui font le pont entre le high school et l'université. À l'heure où les excès de l'industrialisation, qui engendra la spécialisation à outrance, forcent les éducateurs à chercher dans un humanisme spiritualiste et constructif un antidote au matérialisme moderne, il est impérieux que nous conservions l'essentiel d'un enseignement si précieux. Il est même de notre devoir d'en étendre les bienfaits à un plus grand nombre de jeunes gens. Dans les ajustements et les adaptations auxquels il faudra, se résoudre un jour ou l'autre, [p. 180] il est urgent qu'on ne néglige rien pour donner à la jeunesse une formation générale d'autant plus nécessaire que notre survivance économique et sociale nous impose de faire une part importante aux études spécialisées.

Tout compte fait, l'enseignement secondaire classique aura bien agi en ne cédant pas entièrement ni du premier coup aux pressions qui s'exerçaient sur lui. Que serait-il arrivé s'il avait capitulé chaque fois qu'on le sommait de se rendre? Les gages qu'il a déjà donnés l'ont déséquilibré au point qu'il sent maintenant la nécessité de regrouper ses forces. Il sortira transformé de l'épreuve mais il n'en aura acquis que plus de vertus véritables dont la jeunesse fera son profit. Non plus coincé entre deux forces qu'on croyait prêtes à l'anéantir, mais articulé dans l'ensemble d'un système où chacun occupera la place qui lui est naturelle, il ne pourra que rendre de plus grands et de plus signalés services.

\section{DÉVELOPPEMENT DES UNIVERSITÉS}

Comme l'enseignement primaire, celui des universités a subi l'influence de la poussée industrielle et, si on juge par les résultats obtenus depuis trente ans, on serait porté à croire que c'est lui qui a le mieux répondu au défi qui lui fut lancé. Avant 1920, l'université Laval, à Québec, et sa succursale, à Montréal, se contentaient d'être des juxtapositions d'écoles professionnelles où des praticiens bénévoles venaient, en distrayant quelques heures précieuses à leur clientèle, enseigner à, leurs futurs confrères les secrets de leur art. Le professeur de carrière était un phénomène inconnu, les études supérieures étaient inexistantes et la recherche n'intéressait guère que des amateurs isolés, 
étrangers d'ailleurs à la vie universitaire. En même temps que l'université de Montréal, désormais autonome, se lançait dans un programme ambitieux d'enseignement et de recherche en lettres, en sciences, en philosophie et en sciences sociales, de son côté, l'université Laval rajeunie organisait des enseignements semblables et pareillement orientés vers la recherche. Ces deux développements parallèles étaient principalement motivés par le désir de fournir à la jeunesse québécoise les moyens d'obtenir la compétence requise pour participer au progrès technique et économique du pays dont la guerre venait de révéler l'importance à nos compatriotes.

[p. 181]

C'est à ce moment qu'on commença de montrer à la jeunesse qu'elle pouvait et qu'elle devait aspirer à d'autres occupations professionnelles que celles de la pratique légale ou médicale. On avait besoin d'ingénieurs, d'industriels, de chimistes, de physiciens, de biologistes, de géologues, d'économistes et de sociologues; les universités mirent sur pied ou intensifièrent les études qui conduisent à ces carrières. Les progrès purent paraître lents mais l'enseignement universitaire, que vivifie la recherche, est désormais une carrière. Des sociétés savantes naquirent au sein des laboratoires, des publications scientifiques commencèrent de paraitre et, bientôt, de grands instituts furent fondés en microbiologie, en hygiène, en médecine expérimentale, en physiologie, en relations industrielles, en psychologie, en pédagogie et en sciences appliquées. Vers 1933, l'université de Montréal ouvrait les portes de sa Faculté des sciences aux diplômés des écoles primaires supérieures et on voyait plusieurs jeunes filles fréquenter les cours de presque toutes les Facultés. De 125 qu'ils étaient en 1923, le nombre des étudiants en génie à l'École polytechnique passe, moins de dix ans plus tard, à 290, pour atteindre plus de 500 ces dernières années. Cette école possède des laboratoires d'enseignement et de recherche et un Centre de recherches qui sont parmi les plus importants du pays et elle s'apprête à s'installer dans des locaux plus grands encore, sur le campus même de l'université de Montréal à laquelle elle s'est affiliée. À Québec, l'École de chimie, devenue la Faculté des sciences, l'École des mines, et la Faculté de génie forestier enseignent presque toutes les branches du génie et occupent un rang enviable parmi les institutions qui se vouent à la recherche. L'essor de l'École des hautes études commerciales et de l'École universitaire de commerce de Québec n'est pas moins saisissant. Leur influence sur le commerce, l'industrie et la finance gagne chaque jour en importance et insuffle une vie nouvelle à l'économie des Canadiens d'expression française.

Nous avons déjà mentionné que l'évolution des universités vers la spécialisation, sensible dans le domaine des sciences pures et appliquées, importante aussi dans le champ des sciences médicales, a influé sur les destinées de l'enseignement secondaire qui a dû donner plus d'ampleur aux disciplines scientifiques. Dans leurs facultés se sont formés les professeurs de l'enseignement secondaire et les praticiens de la science pure, des sciences appliquées et des sciences sociales, économiques et politiques. Les universités qué-[p. 182] bécoises ont ainsi parcouru, en quelque trente ans, une distance qui les mène bien loin de leur point de départ. 
Deux faits principaux sont la conséquence de cette rapide évolution. Afin de répondre aussi parfaitement que possible aux nécessités de temps et de lieu qui leur sont imposées et auxquelles devront faire face leurs diplômés, les universités Laval et de Montréal, chacune selon sa formule propre, ont abandonné petit à petit la politique d'imitation presque servile de l'université française qu'elles avaient d'abord adoptée. L'influence française y est encore, et le restera probablement toujours importante, car, de toutes les influences étrangères qui peuvent se faire sentir, elle est celle que nous sommes naturellement portés à recevoir et à comprendre. Mais dans leurs cadres et dans la nomenclature des grades universitaires, les universités québécoises ont senti le besoin de se rendre comparables aux institutions canadiennes de langue anglaise. Un industriel qui engage un physicien ou un chimiste n'aura aucun mal à comprendre qu'un bachelier ès sciences physiques de Laval est un candidat qui lui convient tandis qu'il refusera peut-être de se laisser expliquer que la licence ès sciences physiques est un diplôme qui ne diffère guère d'un baccalauréat ès sciences physiques. Afin de rendre les diplômes comparables, on a organisé des cours équivalents à ceux des universités canadiennes de langue anglaise. À tel point qu'il n'y a plus de discussion possible à propos de la valeur de nos baccalauréats ès sciences tandis que nous sommes constamment obligés d'expliquer comment nos baccalauréats ès arts sont, ou non, comparables aux diplômes de même nom que décernent les universités canadiennes de langue anglaise.

La deuxième conséquence est d'ordre économique et financier. L'expansion presque soudaine des enseignements universitaires, la création d'instituts de recherche, la fondation d'écoles nouvelles, l'augmentation de la population étudiante et du personnel enseignant dont la majorité a fait du professorat sa carrière, ont eu comme conséquence de faire dilater le budget de nos universités. Ces progrès ont exigé des locaux nouveaux, plus vastes, mieux outillés et mieux adaptés aux besoins de l'enseignement et de la recherche. Or, de telles transformations supposaient des ressources dépassant de beaucoup celles dont disposaient nos universités et même leurs bienfaiteurs éventuels. Quand les universités ont fait appel à la générosité de la population, celle-ci a montré en quelle haute estime [p. 183] elle tenait l'œuvre universitaire en qui elle voyait l'élément fondamental de notre émancipation économique et de notre avancement culturel. Mais cette aide publique eût été insuffisante si l'État provincial ne fût venu à la rescousse. À plusieurs reprises déjà, le gouvernement provincial avait accordé des octrois aux deux universités. Celle de Montréal n'a pu terminer sa construction sans l'appui financier de l'État; bien mieux, elle tire même une part importante de son budget annuel des coffres du trésor provincial. Comme toutes les autres universités du pays, elle en serait peut-être réduite à cette extrémité même si son évolution n'avait pas été aussi rapide. On ne saurait nier, cependant, entre autres causes, que sa réponse spontanée aux besoins révélés par l'industrialisation a accéléré et accentué la crise financière qu'elle a traversée. La nouvelle charte dont elle fait l'apprentissage consacre en quelque sorte son caractère d'entreprise d'utilité publique sans en faire une université d'état.

Pourrait-on passer sous silence l'aspect nouveau que prennent les questions d'enseignement supérieur depuis que l'État fédéral, à la suite du rapport de la 
Commission Massey-Lévesque, a résolu de venir en aide aux universités ? Sans discuter le mérite de la question, il est intéressant de noter que les commissaires ont écouté les doléances des éducateurs qui leur ont fait voir le sort lamentable de l'enseignement des humanités, qu'on néglige dans la mesure même où on donne plus d'importance et de crédits aux enseignements scientifiques et techniques.

Malgré l'appoint de l'État qui, quel qu'il soit et si bénévole soit-il, risquerait de prendre une part prépondérante dans la structure financière des universités si ces dernières continuent de réclamer son aide, le coût de l'enseignement universitaire a atteint un niveau qui le rend presque inaccessible à certains étudiants. Des bourses, comme celles de l'Aide à la Jeunesse, et des prêts d'honneur ont permis à plusieurs de parer à cette difficulté mais on déplore qu'un grand nombre de jeunes gens doués et méritants ne puissent se prévaloir d'une formation universitaire dont ils feraient plus tard bénéficier la société.

\section{4. ÉLABORATION DE L'ENSEIGNEMENT TECHNIQUE}

Tous les jeunes gens ne sont pas appelés ni toujours aptes à poursuivre des études secondaires ou universitaires. Celles-ci [p. 184] demeureront longtemps, sinon toujours, le privilège d'un nombre relativement restreint d'individus doués et capables d'en profiter. Le sort des autres est divers mais la majorité d'entre eux ont besoin d'être initiés aux métiers et aux techniques utiles dans le monde moderne. Il n'est pas étonnant que, depuis ces dernières années surtout, l'enseignement technique ait accompli d'étonnants progrès dans le Québec. Aux quelques écoles techniques fondées peu après le début du siècle et qui offraient des cours du jour et du soir, sont venues s'ajouter des écoles spécialisées telles que les Écoles du meuble et des arts graphiques, l'École de papeterie des Trois-Rivières, l'École des textiles de Saint-Hyacinthe et un grand nombre d'écoles d'arts et métiers qui, dans presque toutes les villes importantes, constituent un véritable enseignement secondaire technique relevant du ministère du Bien-être social et de la Jeunesse. Des écoles moyennes d'agriculture, une École de laiterie, une École de marine, une École des pêcheries, l'Établissement forestier de Duchesnay, une mine-école, et d'autres encore, s'intéressent à tous les aspects de la vie industrielle du pays québécois tandis que des écoles d'artisanat enseignent les métiers domestiques. L'ensemble de ces institutions constitue une magnifique réponse à la question angoissante que posait l'industrialisation : nos ouvriers pourront-ils, dans cette nouvelle économie, jouer le rôle qui leur revient ou devront-ils se contenter d'être des manœuvres indifférenciés et mal rémunérés? Il est sans doute nécessaire de former des ingénieurs et des savants mais si ceux-ci n'ont, audessous d'eux, qu'une main-d'œuvre pleine de bonne volonté mais peu efficace, on risque de créer un déséquilibre dont les conséquences ne 
tarderaient pas à se faire cruellement sentir. C'est aussi de ce milieu d'ouvriers spécialisés que sortiront bientôt des jeunes gens capables d'accéder à leur tour aux études secondaires et universitaires et dont la plupart, sans doute, à cause de leur milieu, seront plus enclins aux études techniques qu'aux études abstraites. L'École polytechnique a déjà commencé d'admettre à ses cours les diplômés de l'École technique de Montréal qui répondent à ses exigences d'admission.

$\mathrm{Au}$ cours de ce développement de l'enseignement technique, on n'a pas oublié les jeunes filles et on a mis à leur disposition des Écoles de métiers féminins et des Écoles ménagères. Mais ici se dessine une réaction contre l'industrialisation qui menace de distraire la femme de son futur rôle de mère de famille. En changeant leur [p. 185] nom et en modifiant leur programme, les Écoles ménagères régionales sont devenues des Instituts familiaux qui décernent des diplômes permettant à leurs élèves la carrière de maîtresses d'enseignement ménager dans les écoles primaires.

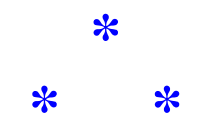

Au moment de conclure, notons que cet exposé, pour être complet, devrait faire état de l'aspect financier du problème scolaire québécois, du syndicalisme dans la profession d'instituteur ainsi que des statistiques rapportant le singulier progrès de l'instruction publique dans le Québec au cours des dernières années. De telles analyses nous entraîneraient au-delà du cadre que nous nous sommes tracé, soit, la description des répercussions de l'industrialisation sur la structure et les programmes de nos écoles à tous les degrés.

Si on nous demande de résumer la situation, nous insisterons sur les problèmes que posent le développement de l'enseignement primaire supérieur et l'expansion de l'enseignement universitaire. Entre ces deux forces animées d'un ressort interne qui répond à chaque nouvel élan de l'industrialisation, l'enseignement secondaire classique se sent de plus en plus comprimé, bien qu'il conserve le prestige d'être la voie royale conduisant aux professions libérales traditionnelles. Il n'est pas besoin d'être pessimiste pour supposer qu'à plus ou moins brève échéance des influences économiques mettront en péril la structure de cet enseignement qui, jusqu'ici, a bénéficié de nombreux privilèges en s'isolant des cadres officiels. Dans son étude, la commission chargée par le Comité catholique du Conseil de l'instruction publique d'étudier la coordination de l'enseignement à tous ses degrés, devra proposer un système qui, non seulement respectera, mais étendra à un plus grand nombre de jeunes gens les bienfaits d'une culture générale et la possibilité d'accéder aux facultés universitaires. Ce serait une démocratisation souhaitable en même temps qu'une mesure de stricte justice envers les enfants doués mais présentement incapables de profiter de ces avantages. Pour cela, il parait opportun que les cadres de l'enseignement secondaire soient unifiés mais qu'à l'intérieur de ceux-ci on puisse à la fois donner la formation générale nécessaire à tous et 
orienter convenablement ceux qui manifestent des aptitudes pour les études abstraites, scientifiques, commerciales ou [p. 186] technique, en ayant soin de tenir compte du sexe des enfants et du milieu agricole ou urbain d'où ils viennent.

L'analyse que nous avons tentée montre qu'on a fait un effort sérieux pour répondre aux exigences nées de notre révolution industrielle. Ces efforts ont réussi dans une certaine mesure mais nous sommes encore loin du compte, ainsi que le révèlent certaines statistiques. Dans une province qui regorge de richesses naturelles que la science et la technique transforment en salaires et en dividendes, le nombre des industriels, des ingénieurs et de gens de science d'expression française est loin de correspondre à l'importance de notre population. Seule une expansion de l'enseignement du second degré pourra conduire aux universités le nombre voulu de candidats aux professions productrices de richesse. Quand on songe que moins de deux mille enfants, y compris ceux de langue anglaise, sont inscrits dans la dernière année du cours primaire supérieur; que quelques centaines seulement fréquentent la même classe des institutions privées équivalentes; que les collèges classiques ne produisent que quelque douze cents bacheliers chaque année; qu'au total, donc, il y a environ trois mille cinq cents enfants susceptibles de s'inscrire dans les universités (et tous ne le peuvent pas), on ne s'étonne pas que les progrès soient lents. En regard de ce nombre, l'Ontario compte plus de treize mille étudiants dans le XIIIth grade qui conduit aux universités. Pour répondre efficacement au défi que nous lance l'industrialisation croissante, nous avons besoin qu'on accorde un soin extrême à la coordination de l'enseignement à tous ses degrés. Sinon, nous serons une fois de plus dépassés par les événements. Il importe cependant que nous évitions les erreurs commises en d'autres milieux et que nous conservions, même au coût de certains sacrifices, le souci de la formation générale qui, au lieu d'être un ornement dont se parent quelques élus, sera la base efficace de la compétence pour un plus grand nombre. Nous ne saurions oublier que l'industrialisation, si elle est une source de richesses pour plusieurs, amène aussi son cortège de problèmes sociaux. La formation générale dont il est question ne saurait être un simple vernis grécolatin qui recouvre un matérialisme foncier mais une solide armature qui soutient tout l'édifice de la spécialisation sans laquelle il n'y a pas de vraie compétence. 
[p. 187]

\title{
COMMENTAIRES
}

\author{
Arthur Tremblay
}

Retour à la table des matières

M. Lortie a brossé un saisissant tableau des répercussions de l'industrialisation sur la structure et les programmes des écoles de la province de Québec. Ce tableau est complet. Je ne vois rien d'essentiel à y ajouter car il met en lumière tous les aspects importants de l'effort tenté par notre système scolaire pour s'adapter aux exigences nouvelles qu'ont entraînées les transformations économiques de notre milieu.

Néanmoins, il serait intéressant, particulièrement pour le bénéfice de ceux qui ne sont pas très familiers avec le système scolaire de la province de Québec, de préciser par des données concrètes, certaines des perturbations générales de notre milieu scolaire que $\mathrm{M}$. Lortie soumet à notre attention. De telles considérations réalistes et objectives nous mettront peut-être aussi en mesure d'évaluer à leur juste degré d'importance des phénomènes qui, à l'heure actuelle, préoccupent plusieurs d'entre nous.

La question à laquelle, me semble-t-il, il faut d'abord répondre pour jauger avec une certaine précision l'influence de l'industrialisation sur notre système d'enseignement est la suivante : "Dans quelle mesure l'industrialisation a-telle participé à l'élaboration de cette structure ou provoqué des déplacements de populations scolaires qui ne se seraient pas produits sans elle ? » Cette influence, comme le souligne M. Lortie, est évidente dans le secteur de la «formation professionnelle» à tous les niveaux. Non seulement a-t-on multiplié les écoles d'un type dont nous possédions déjà quelques exemplaires, telles les écoles d'arts et métiers, mais on a surtout créé beaucoup d'écoles professionnelles de types tout à fait nouveaux : écoles de textile, de papeterie, etc. Entre l'organisation de ce genre d'écoles et le développement industriel de la province, la relation me paraît d'autant plus certaine que plusieurs de ces institutions nouvelles se greffent directement sur une industrie donnée et préparent les techniciens dont elle a besoin : tel est le cas, en particulier, des écoles forestières et de celles que nous venons de mentionner.

Toutefois, il ne semble pas que tous les niveaux de la formation professionnelle aient été également touchés par l'industrialisation. [p. 188] 
C'est au niveau « moyen » et au niveau « supérieur » que les transformations les plus considérables se sont apparemment produites. Au niveau de la formation professionnelle "élémentaire", si l'on excepte les centres d'apprentissage dont la création est toute récente et qui sont encore peu nombreux, nous nous sommes contentés d'assurer une meilleure répartition géographique de deux types d'écoles qui existaient déjà : les écoles d'arts et métiers, et les écoles d'agriculture. Par contre, presque toutes nos écoles moyennes de métiers ont été organisées il y a à peine 25 ou 30 ans; et jusqu'à 1920 environ, l'université ne groupait encore que des facultés à caractère « libéral »: la théologie, la médecine et le droit. Aussi pouvons-nous conclure que l'industrialisation aura profondément modifié la structure de l'université et de l'enseignement professionnel moyen en provoquant la création d'écoles professionnelles manifestement orientées vers l'exploitation des ressources naturelles $\mathrm{du}$ pays. Je verrais même un certain lien entre l'expansion industrielle de notre province et l'institution de facultés apparemment nonindustrielles comme les facultés de sciences sociales. Bien qu'elles soient d'abord ordonnées à l'étude des problèmes humains comme tels, les facultés de ce genre n'apparaissent qu'à partir du moment où la vie sociale a pris des formes et des modalités qui sont en relation directe avec le degré d'industrialisation et d'urbanisation du milieu.

Mais, si importantes qu'elles soient en elles-mêmes, les transformations structurales dont nous venons de parler ne représentent pour ainsi dire que des possibilités théoriques dont la portée réelle dépend du comportement des populations étudiantes auxquelles elles s'adressent. C'est pourquoi je voudrais, à ce point, illustrer certains aspects caractéristiques des effectifs étudiants dans nos établissements scolaires.

Le graphique ci-dessous résume ce que nous pouvons actuellement connaître du degré de mobilité ascendante des jeunes Canadiens français d'un palier à l'autre de notre système d'enseignement. Il est fondé sur des données démographiques récentes puisées dans toute la documentation scolaire disponible. Considérons un groupe de 1,000 garçons, catholiques et français, qui s'inscrivent au premier degré du cours primaire élémentaire, et observons quelle sera leur "carrière scolaire.» Déjà, durant le cours primaire élémentaire, une forte proportion d'entre eux auront abandonné leurs études 
[p. 189]

\section{STRUCTURE ET DÉMOGRAPHIE DE L'ENSEIGNEMENT DANS LA PROVINCE DE QUÉBEC}

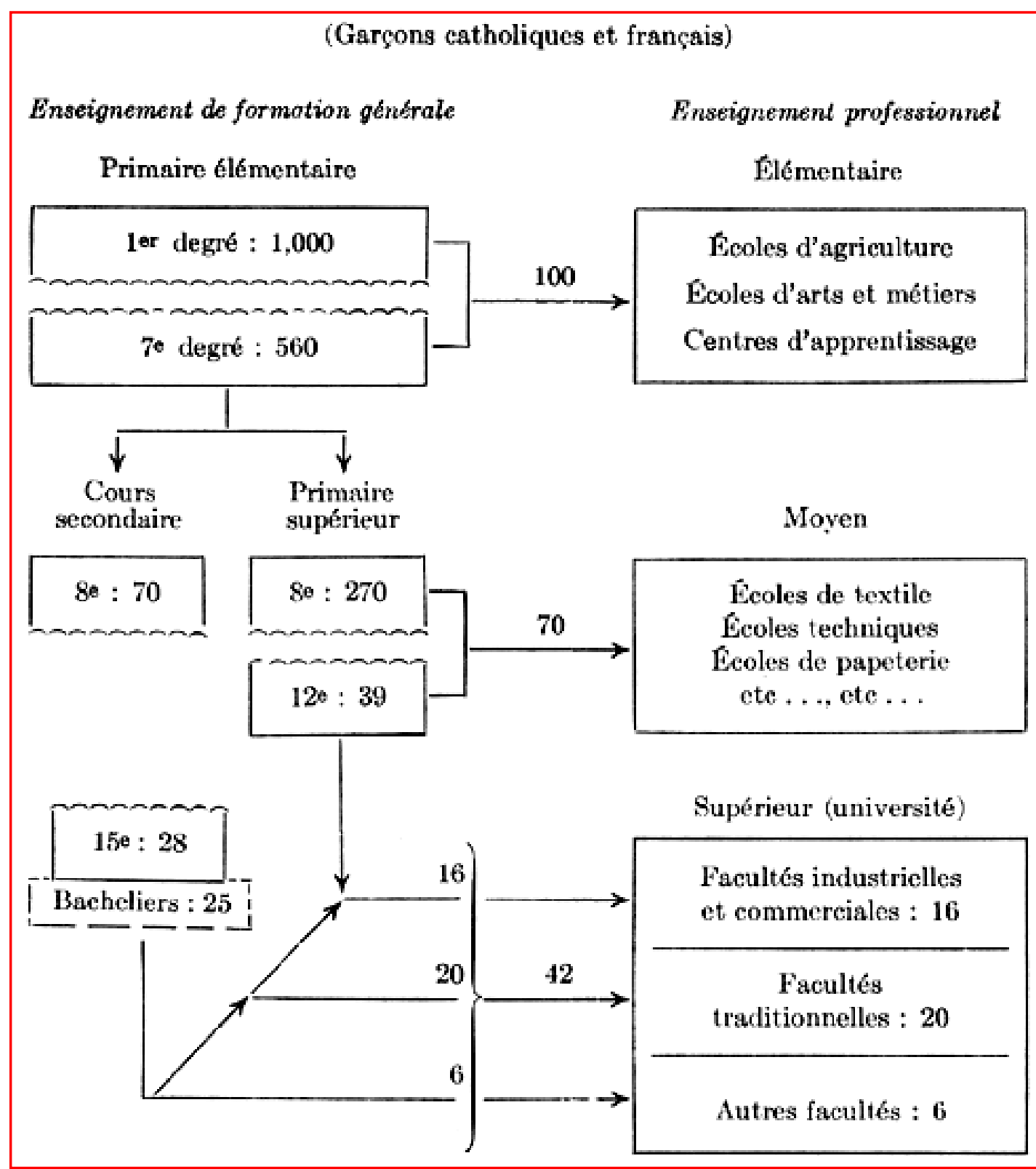

SOURCES : Statistiques de l'Enseignement, 1944-45 ; Annuaire Statistique de la province de Québec, 1950; Statistiques du ministère du Travail et de l'Aide à la Jeunesse, 1951; Annuaires des universités, 1949-50

pour diverses raisons et se seront dirigés vers le travail. Des 1,000 élèves du début il n'en demeurera plus qu'environ 560 en $7^{\mathrm{e}}$ année. Par ailleurs, une centaine se dirigeront, soit avant, soit après leur $7^{\mathrm{e}}$ année, vers des écoles professionnelles « élémen-[p. 190] taires » : écoles d'agriculture, écoles d'arts 
et métiers, centres d'apprentissage. Des 560 qui atteignent la $7^{\mathrm{e}}$ année, 70 vont au cours secondaire et 270 continuent leurs études en $8^{\mathrm{e}}$ année du cours primaire.

Par la suite, après l'un ou l'autre des degrés postérieurs au $7^{\mathrm{e}}$ de l'enseignement primaire supérieur, environ 70 s'orienteront vers des écoles professionnelles «moyennes». Des élèves ayant complété soit le cours secondaire, soit le cours primaire supérieur, un total de 42 accédera aux écoles professionnelles « supérieures » (universitaires). Près de la moitié (un total de 20) de ces derniers s'inscriront à des facultés à caractère libéral ou traditionnel : théologie, médecine ou droit, tandis que près d'un tiers (un total de 16) fréquenteront les facultés qui ont un lien immédiat avec l'industrie ou le commerce : sciences, polytechnique, arpentage, génie forestier, commerce.

Ces données constituent, à mon avis, d'éloquents indices des divers ordres d'influence que l'industrialisation a exercée sur notre enseignement.

En premier lieu, au niveau supérieur de la formation professionnelle: d'inexistantes qu'elles étaient il y a trente ans, les écoles universitaires à caractère industriel ou commercial occupent aujourd'hui, comme pôles d'attraction, un rang presque égal à celui des facultés libérales, bien que cellesci obtiennent encore la préférence. Les premières reçoivent en effet 16 étudiants de notre groupe initial de 1,000, tandis que les secondes en accueillent 20. Bien plus, le milieu de recrutement de ces deux types d'écoles universitaires n'est pas le même. En effet, de la considération de notre échantillon il ressort que, des 1,000 élèves, 25 deviennent bacheliers et 20 parviennent aux facultés universitaires traditionnelles. Comme le baccalauréat ès arts est une condition nécessaire d'entrée dans ces facultés, il est manifeste que quatre-cinquièmes de nos bacheliers se dirigent vers ces dernières. Par contre, les diplômés du cours primaire supérieur qui sont admis à l'université (soit environ un sur trois) vont tous aux facultés industrielles ou commerciales puisque ce sont les seules dont l'accès leur soit permis. Rien d'étonnant qu'ils constituent la majorité des effectifs étudiants de ces facultés.

Deux conclusions découlent de ces observations. D'une part, l'augmentation de la population des collèges classiques, dont l'indice [p. 191] est passé de 100 à 175 au cours de la période 1926-27 à 1944-45, s'est traduite autant à l'avantage démographique des facultés traditionnelles qu'à celui des facultés commerciales et industrielles ${ }^{1}$. D'où l'on peut diagnostiquer une sorte de résistance au mouvement industriel de la part des bacheliers ès arts ; c'est moins à eux qu'aux diplômés d'autres cours «secondaires » que les facultés industrielles ou commerciales doivent l'importance démographique qu'elles ont prise à l'université. À quoi attribuer cette attitude des bacheliers ès arts ? $\mathrm{Au}$ programme des études classiques dont le caractère trop littéraire préparerait mal les candidats aux sciences ou au commerce? Au type de formation dispensée par les collèges en tant que milieux culturels ? Au prestige social et économique des professions libérales ? Autant de questions qui devraient être l'objet d'une recherche approfondie.

Marcel LAUZON, Le besoin d'orientation au cours classique, Document $\mathrm{n}^{\circ} 7 \mathrm{de}$ Pédagogie et d'Orientation, École de Pédagogie et d'Orientation, Québec, 1949. 
D'autre part, bien qu'il soit le principal réservoir d'étudiants pour les facultés industrielles ou commerciales, le cours primaire supérieur ne parvient à conduire à l'université qu'une faible minorité de ceux qui le fréquentent. Ce fait ne s'explique pourtant pas par le manque d'intentions universitaires chez les étudiants eux-mêmes : beaucoup, par exemple, se présentent aux examens d'admission de la Faculté des sciences. Mais sur deux candidats qui s'inscrivent à ces examens, un seul est admis. Ce sont plutôt, par conséquent, les insuffisances de la préparation primaire supérieure qui rendent compte du petit nombre de ses diplômés qui atteignent l'université.

En second lieu, au niveau moyen et élémentaire de la formation professionnelle, nous ne soulignerons qu'un seul fait: les écoles professionnelles des deux niveaux inférieurs ne reçoivent que 17 pour cent de la population étudiante. C'est dire que les quatre-cinquièmes, ou à peu près, des salariés de toutes catégories devront gagner leur vie sans aucune formation professionnelle.

À première vue, l'on pourrait être porté à juger ce fait comme l'indice d'une carence grave du système scolaire. À la réflexion, je crois qu'un jugement de cette nature n'apparaît pas tout à fait fondé. En effet, le travail de l'ouvrier, dans l'industrie moderne, consiste, la plupart du temps, dans une tâche à ce point simplifiée que son exécution ne requiert que quelques heures ou quelques [p. 192] jours d'apprentissage. Par conséquent, il semble plus pratique de ne pas demander à un système d'institutions spécialisées dans la formation professionnelle d'assurer à l'ouvrier cet apprentissage. L'entraînement professionnel est plus efficace et moins coûteux s'il s'acquiert sur place, dans les cadres de l'usine même.

Dans ce cas, le problème scolaire qui se pose n'est plus un problème de formation professionnelle, mais de formation générale de l'ouvrier. La question fondamentale qui doit, à ce sujet, nous préoccuper est la suivante : quel est le type de formation générale qu'il faut aujourd'hui imaginer pour la masse des travailleurs industriels?

La formation que donne le cours primaire élémentaire est encore définie en termes hyper-académiques, si l'on peut dire, lorsqu'on pense à ce qu'elle devrait signifier pour l'ouvrier d'usine. Dans l'hypothèse, toutefois, où le cours primaire élémentaire voudrait s'adapter aux besoins éventuels de la masse des écoliers et les préparer à la vie industrielle, un autre problème surgit. Le cours primaire cesserait d'être une préparation à un secondaire quelconque, pour devenir un terme en soi. Mais alors, quelle serait sa valeur pour les enfants les mieux doués, aux yeux de qui le cours primaire ne saurait être qu'une préparation aux études secondaires ? Faudrait-il, dès le début de la fréquentation scolaire, partager les élèves en deux catégories, en fonction du terme auquel ils parviendront ? Ce sont là des questions vitales, auxquelles, en ce moment même, plusieurs d'entre nous tentent de trouver un commencement de réponse. 
[p. 193]

\title{
CHAPITRE IX
}

\section{NOUVELLES ORIENTATIONS NOUVELLES DE LA PENSÉE SOCIALE}

\author{
Maurice Tremblay
}

\section{$\underline{\text { Retour à la table des matières }}$}

Ce que l'on peut valablement appeler la pensée sociale du Canada français est plus que la somme des opinions d'un certain nombre d'individus sur divers problèmes sociaux. Elle est l'expression d'un ensemble relativement cohérent de conceptions et d'attitudes qui constitue non seulement une " configuration culturelle » au sens où l'entend Ruth Benedict mais un ethos au sens que donne maintenant à ce terme l'anthropologie culturelle. Cet ethos est étayé sur des prémisses qui dominent et informent la culture nationale. Plus que de simples pôles d'intégration logique, ces prémisses représentent un certain idéal. C'est grâce à elles que l'ethos est un système de valeurs et de normes. Ces valeurs et ces normes, renforcées par une approbation séculaire, déterminent les modes de pensée et de comportement que la collectivité reconnaît comme normales.

Dans tout groupe culturel, les conceptions et les attitudes dont est faite la pensée sociale dominante s'imposent aux esprits les plus affranchis et s'incarnent en des institutions dont elles empruntent la fixité. Tout changement radical dans les conditions d'existence du groupe qui entraînera un examen critique de la tradition mettra en cause sa structure sociale aussi bien que les valeurs et les normes de son ethos. Pour autant, la résistance opposée au changement par un système culturel de pensée et par l'organisation sociale qui le supporte sera d'autant plus grande que le nouvel ordre de choses, au lieu d'être le résultat d'une évolution organique du groupe, aura été imposé à celuici de l'extérieur.

Tel est le cas du groupe canadien-français dans le Québec. L'industrialisation qui transforme son milieu depuis une cinquantaine d'années prend le caractère d'un choc auquel ne l'avaient préparé aucune expérience, aucune évolution interne. Rien d'étonnant que les adaptations exigées par ce bouleversement aient trouvé dans la pensée [p. 194] et dans les institutions traditionnelles une opposition tenace. Cette opposition fut d'autant plus vive 
que les Canadiens français étaient fortement intégrés dans un cadre social relativement anachronique.

On ne saurait comprendre les manifestations de la pensée sociale du Canada français aux prises avec une révolution industrielle sans évoquer la conception que se faisait notre société de la civilisation urbaine et des carrières économiques qui maintenant s'imposent à nous. En tout premier lieu, il importe de rappeler comment ces conceptions et leurs incarnations institutionnelles se sont historiquement élaborées.

\section{LA VOCATION PAYSANNE DE LA NATIONALITÉ CANADIENNE-FRANÇAISE}

Il faut reconnaÎtre, en dépit de l'interprétation lyrique fréquemment proposée, que la base économique de la Nouvelle-France, depuis son établissement jusqu'à la conquête, ne fut pas l'agriculture mais le commerce. Durant tout le régime français, la colonisation proprement dite fut subordonnée à la traite des fourrures. C'est grâce au rendement de la traite que Champlain fit reconnaître à Richelieu l'importance de la colonie naissante et qu'il l'amena à fonder la Compagnie des Cent-Associés, compagnie de commerce à laquelle on imposait l'obligation subsidiaire de distribuer des terres et d'établir des colons. Fondée sous le patronage de la traite, la Nouvelle-France doit à celle-ci sa fabuleuse expansion territoriale. C'est à la fois pour suivre la retraite continuelle du castor et devancer l'établissement du trafic rival de l'Angleterre que la colonie s'étendit graduellement de l'Atlantique aux Rocheuses et de la baie d'Hudson au golfe du Mexique ${ }^{1}$.

Toutefois, pendant qu'elle se déployait démesurément en un immense empire commercial, la Nouvelle-France se condensait aussi, lentement et péniblement, sur les bords du Saint-Laurent, en une colonie agricole. La survie de celle-ci fut sans cesse compromise par les besoins d'expansion et de défense de l'empire commercial. Empire commercial, colonie agricole : deux réalités et deux idéals [p. 195] antithétiques, soutenus par deux politiques rivales, celle de l'administration et celle de l'Église, et représentés par deux types de vie opposés : d'une part, celui du seigneur terrien et de l'« habitant »; d'autre part, celui du grand trafiquant de fourrures et du «coureur de bois ». Tels furent les deux pôles divergents d'intégration du destin de la NouvelleFrance.

L'Église, avec les premiers missionnaires et surtout avec $\mathrm{M}^{\text {gr }}$ de Laval, avait pris parti, dès les débuts, pour la colonie agricole contre l'empire

Voir Les Canadiens français et leurs voisins du sud, sous la direction de Gustave LANCTÔT, dans la collection Les relations du Canada avec les États-Unis, Montréal, Éditions Bernard Valiquette, pour la Dotation Carnegie pour la paix internationale, 1941, passim. 
commercial. Elle ne pouvait demeurer insensible au fait que l'établissement de cet empire était fondé, par la traite généralisée de l'eau-de-vie, sur l'avilissement des sauvages, et qu'il avait donné naissance à la classe sociale des «coureurs de bois" dont la vie aventureuse échappait à tout contrôle religieux et moral et semait le scandale parmi les Indiens que les missionnaires s'efforçaient de convertir. En outre de la conversion des sauvages, qu'elle essaya d'ailleurs de fixer à la terre, l'idéal poursuivi par l'Église en NouvelleFrance fut, par le peuplement des seigneuries, l'établissement d'une nouvelle chrétienté fortement intégrée dans les cadres de l'institution paroissiale. Le mode de vie qu'elle encouragea fut celui de l'« habitant», pilier de la colonie agricole, plutôt que celui du «coureur de bois», agent de l'empire commercial. Les intérêts de l'empire commercial étaient, de leur côté, soutenus par tous ceux qui étaient directement intéressés à la traite et par l'administration civile : gouverneurs, intendants et même Conseil souverain.

Ce conflit ne pouvait se régler par la victoire de l'une ou de l'autre partie ni par la domination d'une philosophie de la vie sur l'autre. Si l'Église canadienne avait été solidement établie par $\mathrm{M}^{\mathrm{gr}}$ de Laval et si elle constituait la religion d'État, elle ne possédait encore ni l'autorité ni l'ascendant dont elle devait jouir après la conquête. Si elle pouvait promouvoir son point de vue, elle ne pouvait le faire prévaloir contre l'administration. Celle-ci, forte de l'autorité et du prestige du roi de France, se refusait, selon la meilleure tradition gallicane, à toute intervention directe du pouvoir religieux dans la gérance des affaires temporelles de la colonie, fut-ce au nom de la morale et des intérêts de la foi ${ }^{1}$. Ainsi, sous le régime français, [p. 196] les Canadiens, partagés entre deux allégeances, seront aussi partagés entre deux «vocations », la vocation commerciale et la vocation terrienne, et ni l'une ni l'autre ne recevra une consécration exclusive dans les mœurs et les institutions de la colonie.

Cette dichotomie culturelle sera cependant surmontée après la conquête. Exclus de l'empire commercial passé aux Anglais, les Canadiens n'auront plus d'autre choix que celui de se replier sur les bords du Saint-Laurent et de se consacrer à l'édification de cette solide colonie agricole dont l'Église avait jusque-là rêvé pour eux. L'Église elle-même, dorénavant plus puissante que dans le passé, idéalisera cet inévitable repliement collectif vers la terre en lui reconnaissant le caractère d'une vocation nationale.

En effet, l'administration, en devenant anglaise, avait cessé de faire contrepoids à l'influence de l'Église. Elle avait au contraire affermi celle-ci en obligeant en quelque sorte les Canadiens à se tourner vers le clergé qui seul pouvait défendre leurs intérêts contre le vainqueur. Avec un prestige ainsi renforcé par la conquête elle-même, l'Église constituait, pour les nouveaux sujets britanniques, une force puissante que l'Angleterre pouvait essayer de détruire ou dont elle pouvait essayer de s'accommoder dans le gouvernement de sa nouvelle colonie. Respectueuse du pouvoir établi, l'Église canadienne

W. A. RIDDELL, The rise of ecclesiastical control in Quebec, New York, Longmans, Green and Co., 1916 ; Gustave LANCTÔT, Situation de l'Église canadienne, I, Servitudes de l'Église sous le régime français, Montréal, C. DUCHARME, 1942; Jean-C. FALARDEAU, Rôle et importance de l'Église au Canada français, Esprit, n 193-194, août-septembre 1952, pp. 214.-229. 
était toute disposée à l'accommodement. Bien plus, les autorités anglaises, inquiètes de l'agitation des colonies du sud et convaincues que l'Église, forte de son influence et de son autorité, pouvait seule assurer le loyalisme des Canadiens, optèrent elles-mêmes pour une telle politique. Sans doute aussi inspirées par certains motifs supérieurs d'humanité et de justice, elles accordèrent à l'Église, après quelques hésitations et avec quelques tentatives de rappel, l'autonomie et la liberté que celle-ci exigeait.

L'Église canadienne se servit de sa liberté d'action ainsi reconnue pour orienter le développement d'une chrétienté selon son cœur, une chrétienté essentiellement paysanne. Grâce à une natalité inégalée dans le monde occidental, un peuple se mit à grandir à un rythme étonnant dans les seigneuries de la vallée du Saint-Laurent jusque-là relativement peu peuplées. Ce ne furent pas les manoirs seigneuriaux mais les églises qui constituèrent les centres d'intégration et les symboles de solidarité de la société [p. 197] canadienne-française en voie d'expansion. Le régime seigneurial, avec son mode particulier de division des terres, contribua tout au plus à caractériser la base physique de la société. La paroisse, dirigée par le curé, fut l'unité sociale importante, remplissant à la fois une fonction religieuse et scolaire, et, plus tard, municipale. Dans ces conditions, la prise de possession du sol par les Canadiens français au cours des soixante années qui suivirent la conquête représente pour l'Église une véritable prolifération de communautés de fidèles, au sens littéral et absolu de l'expression.

Ce fut l'âge d'or de l'Église canadienne-française. Elle put facilement, au sein de paroisses rurales isolées où son autorité et son influence étaient souveraines, travailler en pleine liberté à modeler tout un peuple selon son pur et austère idéal de vie chrétienne. Il sembla que l'Église et la nationalité canadienne-française avaient établi, d'un commun accord, un pacte éternel avec la terre qui, encore à sa fertilité première, donnait généreusement. D'après les standards de l'époque, la prospérité régnait dans les campagnes. Ce furent « les bonnes années » dont un dicton populaire a perpétué le souvenir.

Aux alentours de 1820, les terres depuis longtemps exploitées selon des méthodes routinières de culture commencèrent à manifester des signes d'épuisement. Par surcroit, les cadres des anciennes seigneuries devenaient trop étroits pour continuer d'y établir les nouvelles générations. Étant donné l'absence de toute politique agricole de caractère rationnel et permanent, on assista, surtout à partir de 1840, à l'exode vers les villes manufacturières de la Nouvelle-Angleterre alors en pleine expansion industrielle. Le peuple abandonna la terre. Il rompit le pacte pour aller compromettre, dans l'atmosphère « délétère » de villes étrangères, la survie de son catholicisme et de sa nationalité. L'Église s'alarma. On la vit aussitôt prendre la direction d'un héroïque mouvement de colonisation qui, malgré toutes sortes d'obstacles, se poursuivit opiniâtrement dans toutes les régions de la province dont le sol était jugé, à tort ou à raison, apte à la culture.

La pression démographique devenait trop forte. L'agriculture, en dépit d'un début de rénovation, demeurait trop improductive. La saignée vers les ÉtatsUnis continua au rythme effarant d'environ 20,000 départs par année. L'Église ne se résigna pas à cette émigration qui, lui semblait-il, aurait pu être enrayée 
si la population [p. 198] avait consenti à faire les sacrifices nécessaires pour rester fidèle à la terre et, grâce à celle-ci, à la patrie et à l'Église. " Nous comptons sur le concours de tous les parents chrétiens, surtout des cultivateurs, afin que vous donniez vos enfants à la colonisation, ou plutôt à la patrie, à la religion, à Dieu même ", écrivait le cardinal Taschereau en 1880 dans l'une de ses lettres pastorales. Il citait, à l'appui, ce passage du mandement des Pères du sixième concile de Québec, en date du 22 mai 1873 : « Une chose est certaine à nos yeux, c'est que l'émigration n'aurait plus de prétexte et s'arrêterait, si les parents employaient, pour l'argent qui enfants des établissements dans les terres nouvelles, donner à leurs se consume en pure perte pour le luxe et l'intempérance. »

L'Église canadienne-française, toujours dans la perspective de son âge d'or d'après la conquête qui demeure sa grande nostalgie, ne se résignera pas davantage à l'urbanisation rapide du Québec depuis le début de ce siècle. Elle aura tendance à y voir, comme dans l'exode vers les États-Unis, le résultat d'une désertion injustifiée des campagnes et un processus déchristianisant qu'on pourrait encore, sinon renverser, du moins enrayer par la colonisation intensive de terres nouvelles. La continuité de pensée de l'Église canadiennefrançaise à ce sujet ressort clairement de la Lettre collective que l'Épiscopat de la province consacrait en 1946 au problème de la colonisation et où il est dit : «... Chez-nous, la vie s'est implantée par l'œuvre colonisatrice. Aussi chaque fois qu'on l'a sentie menacée, que ce soit par l'émigration à l'étranger comme au temps de $\mathrm{M}^{\mathrm{gr}}$ Bourget, ou par la fascination des villes comme il arrive de nos jours, on a élevé la voix pour signaler le danger, déplorer l'affaiblissement de l'esprit chrétien et pousser vers les terres neuves. Aux descendants des défricheurs apôtres de comprendre les avantages qu'il y a à continuer leur mission, à agrandir le corps mystique du Christ, en ouvrant des paroisses nouvelles et en baptisant la terre canadienne pour qu'elle garde bien vivante et la foi et les vertus de nos ancêtres. »

Il ne faut cependant pas croire que l'Église ait été seule à exalter et à tâcher de sauvegarder cette vocation terrienne de la nationalité canadienne-française. C'est là un thème autour duquel la pensée nationale s'est cristallisée avec une inaltérable unanimité. En effet, la paroisse rurale a été le cadre dans lequel notre catholicisme [p. 199] a trouvé son style et où il peut encore le mieux conserver ses traits dominants. Elle a aussi été, d'une façon plus générale, le milieu naturel où notre groupe ethnique a acquis ses caractères typiques et où il a pu poursuivre, dans la liberté de l'isolement, son idéal traditionnel de survie dans l'immuabilité. "La fidélité à la terre » a été, surtout depuis cent ans, un thème majeur de l'enseignement de l'Église et du clergé, de la littérature, de la tribune et de la presse. Dans le roman en particulier, il faudra attendre Ringuet, Roger Lemelin et Gabrielle Roy pour rompre avec le genre traditionnel des pastorales.

L'une des prémisses de la pensée sociale au Canada français repose donc sur la conviction que notre peuple, s'il veut survivre en tant que groupe catholique et français en Amérique, doit demeurer fidèle à une vocation paysanne. On comprend facilement que cette pensée soit désemparée devant le phénomène de la révolution industrielle qui, en quelques années, a conduit 
plus de 65 pour cent de notre population dans les villes. Elle est profondément troublée du fait que la paroisse ait perdu, dans la complexité des structures sociales urbaines, son caractère de société globale à base religieuse, et que la famille, dépouillée de la plupart des fonctions qu'elle remplissait à la campagne, commence à se désintégrer et à cesser d'obéir aussi spontanément au grand précepte catholique et «national» de la fécondité. Elle est d'autant plus perplexe qu'avec la même révolution industrielle réapparaît, d'une façon tragique, le dilemme historique qu'elle croyait à jamais résolu. À l'empire commercial d'autrefois qui, aux confins de la colonie agricole, offrait une option patriotique au service du roi de France, s'est substitué l'« empire» industriel nord-américain qui, envahissant notre milieu, nous a imposé une «domination» économique étrangère. Cette domination proposait à notre fierté nationale un ultimatum d'autant plus douloureux qu'elle se doublait d'une invasion ethnique et qu'elle nous établissait dans une condition d'infériorité économique à l'intérieur même de notre propre province. Il fallait, par devoir patriotique, reconquérir sinon l'indépendance, du moins l'égalité économique avec les nouveaux venus, Américains, Britanniques ou Canadiens anglais, qui s'installaient chez nous alors que nous n'étions préparés à fournir que la maind'œuvre. Il fallait nous ré-orienter vers les affaires et les carrières techniques. Or, une telle ré-orientation était et demeure difficile, vu qu'elle [p. 200] contredit toute notre tradition paysanne ainsi qu'une conception de la vie qui nous empêche de rivaliser sur un pied d'égalité avec nos concitoyens angloprotestants dans les hautes sphères de l'activité économique.

Il importe, à ce point, de noter certains plans de la vie sociale où cette conception de la vie rend particulièrement difficile notre pleine réintégration dans la vie économique du continent. Je veux parler de notre régime de classes sociales et de notre système d'enseignement. $\mathrm{Si}$, dans la culture anglocanadienne, le succès en affaires et dans les carrières techniques est considéré comme une valeur primordiale, il n'en est pas ainsi chez les Canadiens français.

\section{LES CLASSES SOCIALES}

D'après l'estimation commune traditionnelle, encore largement dominante aujourd'hui, le sommet de l'échelle sociale au Canada français n'est pas occupé par l'homme d'affaires prospère, ni par l'ingénieur, mais par le prêtre et le professionnel des arts libéraux.

Le grand rêve de la plupart des parents, dans une société aussi naturellement et spontanément catholique et où l'Église jouit d'une aussi profonde influence et d'une considération aussi indiscutée, est de voir un jour au moins l'un de leurs fils " élevé à la prêtrise », selon l'expression consacrée qui revêt ici une profonde signification sociale. Une vocation sacerdotale dans une famille est considérée comme une faveur insigne de Dieu et comme un accomplissement social dont on tire fierté et prestige. Il n'est pas étonnant que, chaque année, près de la moitié des gradués du cours classique se dirigent vers la prêtrise. 
Durant plus d'un siècle, les médecins, les avocats et les notaires ont constitué à eux seuls l'élite laïque du peuple. Citoyens les plus notables dans leurs localités respectives, c'est eux qu'on s'est habitué de choisir de préférence pour les charges publiques. Encore aujourd'hui, une proportion imposante des députés qu'on élit à la Législature provinciale et au Parlement fédéral sortent de leurs rangs. Chez un peuple passionné de politique, ce rôle joué par les professionnels des arts libéraux dans la vie publique ne pouvait qu'affermir et consacrer un prestige déjà établi par la supériorité de leur occupation et leur culture intellectuelle. Étant donné [p. 201] l'orientation de la formation donnée dans les collèges classiques, chaque professionnel était par définition un homme cultivé, versé en littérature et curieux des choses de l'esprit. Étant donné que les universités canadiennes-françaises, jusqu'au début de ce siècle, ne préparaient pas à d'autres carrières, le médecin, l'avocat et le notaire se trouvèrent les seuls à jouir de l'ascendant d'une formation universitaire ${ }^{1}$.

Depuis, l'ingénieur, le chimiste, l'agronome, le licencié en lettres, le spécialiste en sciences commerciales et d'autres bénéficient de titres universitaires, mais leurs professions nouvelles n'ont pas encore réussi à s'établir dans l'estime commune sur un plan d'égalité avec la trilogie traditionnelle. Quant à l'homme d'affaires, quel que soit le succès de ses entreprises, il est encore loin d'avoir atteint un statut social égal à celui qu'assurent les professions libérales. La fille d'un avocat ou d'un médecin se considérera comme socialement supérieure à la fille d'un grand marchand ou d'un entrepreneur et, à l'occasion, le lui fera sentir. L'homme d'affaires, de son côté, reconnaît son infériorité sociale relative par le soin empressé qu'il met à diriger les mieux doués de ses fils vers le cours classique et les professions libérales, souvent même aux dépens de la prospérité de son entreprise ou de la permanence de celle-ci comme propriété « familiale».

Cette situation privilégiée du clergé et de la classe professionnelle, avec tout le mécanisme élaboré d'attitudes, de symboles et de comportements par lequel elle s'affirme et se maintient, peut encore se constater quotidiennement. Puisque les talents, ici comme ailleurs, s'orientent spontanément vers les situations de plus grand prestige social, l'ascendant dont jouissent encore la prêtrise et les professions libérales au détriment de la carrière des affaires demeure pour notre société une cause de retard économique.

\section{LE COLLÈGE CLASSIQUE}

Dans la perspective de ce préjugé défavorable dont sont victimes les occupations associées à la vie économique, on peut affirmer que notre régime de classes sociales est polarisé, en définitive, par le collège classique. Celui-ci est au centre même de notre [p. 202] système d'enseignement. " Faire son cours classique » est la première réalisation exigée de quiconque veut être

Jean-C. FALARDEAU, Réflexions sur nos classes sociales, Nouvelle Revue canadienne, vol. 1, n³, juin-juillet, 1951, pp. 6-9. 
admis dans la classe supérieure de la société. Celui qui aura suivi un cours commercial ou scientifique, quel que soit par ailleurs son succès dans la vie, sera toujours un peu considéré comme un "primaire » par les gradués du cours classique. On jugera qu'il manque un fini nécessaire à sa culture, un titre essentiel à sa promotion sociale. Le dédain plus ou moins manifeste des étudiants des collèges classiques pour les étudiants des collèges commerciaux ou scientifiques et le ressentiment réciproque de ces derniers reflètent le même jugement de valeur.

Le cours classique prépare surtout de futurs prêtres et de futurs « professionnels ». La considération sociale dont il jouit est un signe que l'on continue à approuver une orientation intellectuelle et sociale qui est loin de favoriser l'initiation aux affaires en général ni la formation du businessman en particulier. Dans beaucoup de collèges classiques, jusqu'à la dernière des huit années que dure le cours, l'étudiant est considéré comme un prêtre virtuel et traité en conséquence. Étant donné l'« appel » de Dieu, toujours possible, les prêtres qui dirigent les collèges s'appliquent à former tous les étudiants comme si chacun était appelé à devenir prêtre. Cette formation, incarnée dans un régime de vie quasi-monastique, est toute orientée vers les valeurs surnaturelles : la gloire de Dieu et le salut de l'âme par la pratique des vertus chrétiennes et la fuite du péché. Dans le même esprit surnaturel, une carrière dans le «monde » est présentée comme étant un état de vie intrinsèquement inférieur et rempli de périls spirituels, dans lequel on peut sans doute atteindre son salut, mais en vue duquel les éducateurs ne proposent aucune orientation positive, sauf peut-être durant la toute dernière année du cours. On conçoit qu'une telle éducation morale ne tende guère à développer des ambitions de succès et de gloire terrestres, encore moins le désir d'enrichissement dans le commerce, la finance ou l'industrie : de telles ambitions pourraient détruire de précieuses vocations sacerdotales que les collèges classiques se sont donné la mission de cultiver et de produire en grand nombre.

En définitive, je crois que l'on peut accepter le jugement d'ensemble que porte sur nos collèges le journaliste américain William Henry Chamberlin lorsqu'il écrit : «L'exemplaire d'humanité qu'a [p. 203] tendance à fabriquer le collège classique, c'est le gentleman canadien-français solidement convaincu de sa foi religieuse, cultivé d'une façon peut-être un peu démodée, affable, spirituel et logique selon les données de l'enseignement reçu. C'est la formation préalable par excellence pour le prêtre, l'avocat et l'homme de profession, pour le journaliste et le chef politique, mais elle n'est pas en mesure, règle générale, de préparer des hommes particulièrement qualifiés pour les occupations mercantiles de l'ère industrielle. ${ }^{1}$ "»

Il nous reste à nous demander à quoi tient en dernière analyse cette sorte de fin de non-recevoir qu'opposent aux carrières économiques le régime des classes sociales et le collège classique des Canadiens français. Quelles sont, en d'autres termes, les prémisses dont dépend la pensée sociale collective?

Le Canada vu par un Américain, traduction par Roger DUHAMEL de Canada Today and Tomorrow, Éditions de l'Arbre, Montréal, 1943, p. 212. 


\section{LE CARACTÈRE FRANÇAIS}

La première de ces prémisses semble dériver du tempérament français luimême, relativement préservé en même temps que la culture française durant trois siècles d'histoire sur les bords du Saint-Laurent. «Le Français, écrit encore William Henry Chamberlin, étant donné sa personnalité individuelle et sa culture, peut être un épicurien ou un ascète, mais il est rarement un brasseur d'affaires du type Babbitt. " Son idéalisme, son culte de la pensée et des valeurs universelles de l'esprit l'empêchent d'attribuer un prestige supérieur au pragmatisme et au mercantilisme des grandes réussites financières.

Il y a aussi dans le tempérament français un goût du loisir et un idéal de rentier incompatibles avec la vie trépidante et absorbante des affaires telles qu'elles sont généralement pratiquées dans les pays anglo-saxons. Pour le Français, le travail n'est pas l'essence ni le but de la vie, mais plutôt le soutien d'une vie qui vaut la peine d'être vécue pour elle-même. Il sera porté à y apporter un certain détachement, voire une indolence qui sont tout à fait conciliables avec le respect qu'il a de lui-même. De façon générale, à la différence du businessman anglo-saxon, ce n'est pas au bureau, au milieu des secrétaires et des téléphones, ni au club où l'on continue à promouvoir les intérêts de ses entreprises, [p. 204] que l'homme d'affaires français sera enclin à situer le lieu où il trouve sa principale raison d'être. Brasser des affaires pour le seul plaisir de la chose, s'absorber à tirer le maximum d'avantages des conditions du marché et du jeu des forces économiques, devenir riche par sens du devoir ou par sport ne sont guère des manifestations du tempérament français. Bien plus, l'individualisme dont nous sommes les héritiers nous incline à établir des entreprises de caractère familial. Il est vrai que nous consentirons volontiers à nous départir de celles-ci si un acquéreur imposant nous propose un prix alléchant, mais notre prudence innée nous retient, en général, de grouper nos capitaux pour fonder de ces grandes sociétés anonymes qui sont les formes typiques du contrôle économique contemporain.

Ce qui subsiste en nous du tempérament français détermine une attitude d'apathie ou de défiance envers les « grandes affaires » telles qu'on les conçoit et les pratique généralement dans les pays anglo-saxons. C'est de cette attitude qu'il faut tenir compte pour interpréter, dans une très large mesure, le prestige supérieur de nos professions libérales et le caractère humaniste de notre cours classique. 


\section{LA PHILOSOPHIE CATHOLIQUE DE LA VIE}

Un autre facteur qui permet peut-être davantage d'expliquer notre sens particulier des affaires tient à la conception de l'existence qui nous vient du catholicisme. Ce facteur a d'autant plus d'importance que, pour les Canadiens français, la religion catholique constitue pour ainsi dire, un élément intégrant de la nationalité.

Or, à la différence du protestantisme ascétique qui semble historiquement lié à l'expansion du capitalisme, le catholicisme n'a pas tenté de ramener le royaume de Dieu sur la place du marché. Pour l'Église, les valeurs de contemplation sont demeurées supérieures aux valeurs d'action; la grâce et la vertu chrétiennes sont demeurées dissociées du succès des entreprises terrestres. La réussite dans les affaires et dans les occupations séculières n'a jamais représenté, à ses yeux, la valeur symbolique d'une confirmation de la grâce et d'un signe de prédestination. Au contraire, en morale individuelle, on a continué d'y voir une source d'orgueil et un danger de détournement des voies de la vertu et du salut [p. 205] éternel. En pays catholique le God's a gold de l'austère et implacable Rockefeller aurait été un sujet de réprobation et de scandale. Parallèlement, la notion de vocation ou de calling n'a pas été sécularisée chez les Catholiques comme elle l'a été chez les Protestants. Dans son acception mystique, elle continue de signifier seulement l'appel à la vie religieuse : elle ne s'étend ni aux affaires ni, d'une façon générale, aux occupations temporelles. Le mot de Calvin Coolidge: «L'homme qui construit une usine, édifie un temple », aurait difficilement pu être prononcé par un Catholique.

Cette philosophie catholique de la vie qui, à la différence de celle qui prévaut parmi les Protestants, ne comporte aucune incitation positive à l'édification des grandes entreprises capitalistes, a pu perdre de son emprise locale au cours des dernières années. Elle n'en demeure pas moins dominante chez les Canadiens français, perpétuée par un clergé nombreux et respecté. Il n'est donc pas étonnant que le money maker n'ait pas chez nous le prestige et les encouragements sociaux qui lui sont accordés par les Anglo-protestants du reste du continent. Au surplus, l'enseignement social des derniers papes, qui est venu se superposer comme naturellement à notre pensée sociale, n'a pas contribué, par sa sévérité justifiée envers le capitalisme, à réhabiliter dans notre estime le type d'homme d'affaires dont notre « élite » n'avait pas osé, par instinct, imiter le modèle, même au prix d'une situation d'infériorité à l'intérieur de l'empire industriel nord-américain. 


\section{LES FRUSTRATIONS COLLECTIVES}

L'allusion au tempérament français et à la religion catholique n'explique qu'en partie l'attitude réfractaire aux affaires qui caractérise la pensée sociale des Canadiens français, Il faut aussi voir dans cette attitude l'expression d'un phénomène de compensation pour les frustrations et les déboires économiques que leur a valus la conquête. Nous venons d'évoquer comment, au moment de la cession du Canada à l'Angleterre, les Canadiens français furent exclus de l'empire commercial et refoulés vers la terre. Il était quasi inévitable que, placés en état d'infériorité dans le domaine des hautes activités commerciales, financières et industrielles, ils éprouvent un profond ressentiment et que, par compensation, ils minimisent les activités économiques et exaltent, avec la vocation [p. 206] terrienne, les carrières qui demeuraient ouvertes à leur élite, dans la politique, le clergé et les professions libérales.

Quoi d'autre que cette attitude ambivalente se manifeste, par exemple, dans l'admiration que nous éprouvons pour les talents et les réussites de nos compatriotes canadiens-anglais sur le plan économique, et, inversement, dans le peu de confiance que vous avons dans les aptitudes et le succès « des nôtres » sur ce même plan ? C'est contre ce complexe d'infériorité que l'abbé Groulx exhortait la jeunesse à réagir, dans une conférence qu'il prononçait en 1936 devant la Chambre de commerce cadette de Montréal: "Par vos réussites, disait-il, redonnez confiance à vos compatriotes. Rendez-leur la foi aux vertus pratiques du génie national, de la raison française. Enlevez-leur cette mentalité de vaincus qui ne les laisse croire qu'au succès des autres. Dissipez l'envoûtement où les tient le prestige de la richesse du voisin. Débarrassez, par exemple, nos pauvres paysans et nos pauvres campagnards de ces attitudes humiliantes qui nous les montrent, à leur entrée en certains grands magasins de l'ouest de Montréal, avec des yeux embués de mystique, comme s'ils franchissaient la porte d'un temple merveilleux ou d'un sanctuaire national, et se donnant l'air de chercher un bénitier pour se signer. Et, concluait-il, débarrassez surtout notre peuple de cette humiliation collective et foncière qui fait voir une population de 2,300,000 âmes, orientant ses enfants et son enseignement, et ceci comme à une fin normale, à se préparer de l'emploi chez une minorité d'à peine 500,000 âmes. ${ }^{1}$ »"

L'abbé Lionel GROULX, L'économique et le national, L'Imprimerie Populaire, Montréal, 1936 ; p. 16. 


\section{LA CRISE DE LA PENSÉE SOCIALE CANADIENNE-FRANÇAISE}

De tels appels patriotiques à la " libération économique » de notre peuple réduit au rôle de serviteur dans sa propre maison se heurtent, comme nous l'avons établi, à toutes les forces conjuguées de la tradition. Ils sont toujours plus ou moins étouffés par un autre appel, celui que formulait $\mathrm{M}^{\mathrm{gr}}$ Pâquet, le 23 juin 1902, à l'occasion des noces d'or de la Société Saint-Jean-Baptiste de Québec, dans un sermon fameux que l'Action française rééditait en 1925, sous le titre significatif de «Bréviaire du patriote canadien-[p. 207] français ». « Notre mission, déclarait $\mathrm{M}^{\text {gr }}$ Pâquet à cette occasion, est moins de manier des capitaux que de remuer des idées; elle consiste moins à allumer le feu des usines qu'à entretenir et à faire rayonner au loin le foyer lumineux de la religion et de la pensée ... Laissons à d'autres nations, moins éprises d'idéal, ce mercantilisme fiévreux et ce grossier naturalisme qui les rivent à la matière. Notre ambition, à nous, doit tendre et viser plus haut; plus hautes doivent être nos pensées, plus hautes nos aspirations ... Pendant que nos rivaux revendiquent, sans doute dans des luttes courtoises, l'hégémonie de l'industrie et de la finance, nous ambitionnerons avant tout l'honneur de la doctrine et les palmes de l'apostolat. » Tiraillée entre ces deux pôles opposés, la pensée sociale canadienne-française a longtemps hésité et se cherche encore.

Quand, vers 1910, M. Édouard Montpetit reprit le mot d'ordre d'Errol Bouchette, resté sans écho à la fin du siècle précédent : «Emparons-nous de l'industrie », il pouvait déclarer : " On pose le problème économique ; on le pose comme un blasphème, mais on le pose tout de même. " Rappelant, en 1938, l'hostilité qu'il avait rencontrée à cette époque, il écrivait: "Mais comment prêcher l'éveil économique sans prendre le parti de la richesse ? Ce fut un beau tapage sur la Colline inspirée. S'enrichir, quelle dangereuse doctrine! N'avons-nous pas, contre l'opulence des autres, dressé depuis toujours l'intelligence? Contre l'enseignement pratique, les disciplines inestimables du classicisme ? Et contre le matérialisme, la pauvreté vengeresse d'un idéalisme miteux ... Je pense en souriant, continuait-il, à l'article d'un journaliste de Québec, qui étouffait mes audaces au berceau. Il m'opposait la parole de l'Évangile : Il est plus facile à un chameau de passer par le chas d'une aiguille qu'à un riche de gagner le Royaume du ciel. Tout y était, y compris le soupçon d'incrédulité qu'il convenait de laisser planer sur un frais émoulu d'Europe, comme on désignait ceux qui, revenus de Paris, appliquaient à leur pays une science joyeusement acquise et pensée nationalement ... L'accord n'était pas facile. L'aspect matériel de notre problème national paraissait accessoire. Aspect accessoire si l'on veut, m'écriai-je, mais aspect tout de même d'une question plus considérable. La puissance économique amoindrit-elle nécessairement l'esprit ? ... Ce fut assez long. On admettait mon raisonnement, mais je sentais toujours une résistance. Aujourd'hui le [p. 208] préjugé, - c'est peut-être un mot trop fort - est tombé. La logique a triomphé même chez ceux qui demandaient à réfléchir. J'applaudis, on le pense bien, à 
la déclaration si nette, si consolante aussi, de Monsieur l'abbé Groulx : S'il est vrai, redit-on, que les aspirations morales d'un peuple doivent passer avant toute chose, il est aussi vrai, dans notre monde renversé, que les forces économiques et les puissances d'argent commandent trop souvent les puissances morales et qu'un peuple n'est vraiment maitre de sa vie spirituelle que s'il détient l'entière administration de son patrimoine matériel. ${ }^{1}$ »"

M. Montpetit ne semble pas avoir vu que, du fait que cette revalorisation de l'ambition économique s'accomplissait sous l'égide nationaliste, elle introduisait dans notre pensée sociale un impossible idéal d'enrichissement collectif en vase clos. Il était, et il est encore utopique de prétendre appliquer, telle quelle, une philosophie traditionnellement ethnocentrique à un ordre économique qui s'exerce dorénavant à l'échelle continentale. À moins d'adopter le socialisme (ce qui serait, à notre avis, la seule attitude nationaliste complètement logique), il nous semble que c'est affoler inutilement notre pensée sociale que d'y incorporer d'en seul coup d'irréalisables rêves d'indépendance économique «nationale». Une telle aspiration est d'autant plus nébuleuse que l'on prétend reconquérir cette indépendance tout en refusant de donner à la richesse matérielle le sens que lui donnent nos concurrents anglo-protestants, comme aussi en refusant, selon l'expression même de l'abbé Groulx, de « quitter l'ordre latin ».

C'est là une des principales contradictions que comporte l'idéal « national » d'autarcie économique qui a été mis de l'avant à l'époque contemporaine par l'école nationaliste canadienne-française dont l'influence demeure dominante. Cette contradiction a créé chez nous un état de désarroi idéologique et psychologique. C'est peut-être ce désarroi lui-même qui empêche encore notre pensée sociale, située au carrefour de trois civilisations et illuminée par Rome, d'apporter au monde toutes les contributions qu'on serait en droit d'attendre d'elle.

Maurice TREMBLAY

Édouard MONTPETIT, Les Canadiens français et l'économique, Mémoires de la Société royale du Canada, 1938, section I, p. 58. 
[p. 209]

\section{COMMENTAIRES}

\section{Jacques Cousineau, s.j.}

\section{$\underline{\text { Retour à la table des matières }}$}

L'exposé de M. Maurice Tremblay mérite les plus vifs éloges. L'auteur a bien décrit la constante, que j'appellerais primordiale, de la pensée sociale du Canada français traditionnel : la vocation paysanne, dont il a magnifiquement établi les origines historiques et montré les aboutissants institutionnels. Après quoi il a analysé avec subtilité, en sociologue, la réaction de cette mentalité canadienne-française de type plutôt rural à l'invasion industrielle, telle qu'elle s'exprimait à un moment que j'établirais aux environs de 1939, avant la deuxième grande guerre. Enfin, pour expliquer cette réaction, il est remonté aux sources : caractère français, philosophie catholique de la vie, idéologie nationaliste. Et il nous laisse en pleine crise de la pensée sociale.

Je devine que l'auteur, ayant disposé tous les éléments d'un jugement, a voulu laisser à la discussion le soin de déterminer le sens de l'orientation nouvelle de la pensée sociale dans notre milieu. Pour ma part, j'aimerais soumettre immédiatement deux remarques qui me permettront de prolonger la synthèse de $\mathrm{M}$. Tremblay, tout en suggérant deux légères corrections en vue d'un jugement définitif. Ces remarques portent sur les tendances sociales exprimées par notre clergé et sur notre syndicalisme depuis environ dix ans, comme des signes certains d'une orientation nouvelle, à la fois ferme et décisive, de la pensée sociale canadienne-française.

On ne peut nier le rôle important du clergé dans la pensée sociale de notre pays, surtout s'il s'agit de la hiérarchie, dont l'attitude est primordiale dans une société aussi autoritaire que la nôtre. Cette attitude a été exprimée dans un document publié en 1950 et que j'estime capital : la Lettre pastorale collective sur le problème ouvrier. Aucun document canadien-français n'a eu autant d'importance sociale, aucun n'aura la même influence. Son édition originale de 100,000 exemplaires a été vendue et il était déjà, il y a deux ans et demi, traduit en quatre langues. Il a été loué partout dans le monde comme un grand document social et la Sacrée Congrégation du Concile en a félicité les auteurs, geste rarissime dans les annales ecclésiastiques. Or, si l'on tient compte de la façon dont ce genre de document s'écrit, on peut dire que [p. 210] cette Lettre est un aboutissement, tout comme le fut l'encyclique Rerum Novarum. Tous savent que Rerum Novarum, paru en 1891, fut le résultat de recherche de pensée et de poursuite d'action de la part de divers groupements, comme l'Union de Fribourg, et de nombreuses personnalités qu'on a appelées les "Catholiques sociaux ». Le génial Pape Léon XIII, à un moment donné, a codifié ces idées dans cette grande charte du Travail, pierre de base de la 
pensée sociale occidentale contemporaine. Le mouvement existait qui fut pour lors comme consacré et élevé à la dignité de norme universelle.

Il en fut ainsi au Canada français. Il existe dans le clergé canadien-français, surtout depuis les années 1940 et suivantes, un mouvement social puissant qui s'est d'abord exprimé dans ce qu'on appelle les «Journées sacerdotales d'études sociales » où, chaque année, tous les prêtres ayant des préoccupations sociales se réunissaient. En 1944, ils étaient au nombre de soixante. À Sherbrooke, en avril 1952, ils étaient déjà 130. Ces prêtres sont d'ordinaire envoyés par leur évêque ou viennent d'associations économico-sociales dont ils sont les conseillers, des mouvements d'action catholique dont ils sont les aumôniers, enfin des universités ou institutions d'enseignement secondaire où ils dispensent la lumière sociale. Ces «Journées sacerdotales d'études sociales », encouragées par la hiérarchie, ont éventuellement donné naissance à ce qu'on appelle la " Commission sacerdotale d'études sociales » qui a eu, vers les années 1948-49, un certain retentissement par ses interventions opportunes et efficaces. Tous ces prêtres travaillaient alors en milieu urbain; depuis quelques années, se sont joints à eux, heureusement, les prêtres travaillant dans le milieu rural. Le but fondamental de cette activité sacerdotale n'a cessé d'être la réalisation de l'unité de pensée pour une meilleure harmonie de l'apostolat. C'est de cette recherche d'une unité progressive de pensée dans l'adaptation au milieu, c'est de l'élaboration de cette pensée sacerdotale mise au point, ordonnée et codifiée par des évêques avertis, qu'est finalement sortie la Lettre sur le problème ouvrier.

Cette Lettre révèle une attitude nouvelle de la part de la hiérarchie catholique au Canada français. M. Tremblay résume ainsi l'attitude d'autrefois : " L'Église canadienne-française, toujours dans la perspective de son âge d'or d'après la conquête qui demeure [p. 211] sa grande nostalgie, ne se résignera pas davantage à l'urbanisation rapide du Québec depuis le début de ce siècle ... »Or au paragraphe 84 de la Lettre, je vois que les évêques renversent leur politique de cent cinquante ans. C'est en ce sens que ce document est capital dans l'histoire sociale du Canada français. Voici ce paragraphe, qui se donne comme la conclusion de la deuxième partie, plus doctrinale : «Par le respect des valeurs religieuses et familiales, par une saine orientation des loisirs et une juste conception du travail, par une meilleure organisation du travail sur les plans de l'entreprise, de la profession et de l'économie nationale, s'établira au pays un régime économique et social conforme à la doctrine de l'Église, en somme une condition ouvrière chrétienne qui corresponde sur un autre plan à ce qui fut autrefois notre civilisation agricole. Comme c'est encore le cas pour la partie de nos fidèles qui vivent en milieu rural, l'ouvrier sentira qu'il a sa place dans la société. Il ne sera pas un homme sans attaches, un déraciné, un ignoré. Il sera fier de lui-même, parce qu'en réfléchissant sur lui-même et sur la noblesse de son travail, il aura découvert qu'il a une véritable vocation en ce monde ; il fera alliance avec cette vocation, il aimera sa vie d'ouvrier ... ${ }^{1}$ "

Le problème ouvrier en regard de la doctrine sociale de l'Église, Lettre pastorale collective de Leurs Excellences Nosseigneurs les archevêques et évêques de la province 
À mon humble avis, nos évêques, dans cette Lettre, appellent les Canadiens français à une vocation non plus seulement paysanne mais intégrale, urbaine et rurale. La preuve péremptoire en est fournie au paragraphe 37 : «C'est notre devoir de regarder le problème ouvrier dans le plan de Dieu. Si la vie ouvrière des villes, dans les conditions où elle s'est développée dans le passé, s'est montrée moins saine et moins protectrice des valeurs humaines que la vie rurale, il ne faudrait pas croire qu'elle est nécessairement meurtrière des âmes ... Le milieu ouvrier et industriel peut être sanctificateur. ${ }^{1}$ " Ces paroles manifestent, dans l'évolution de la pensée sociale au Canada français, un tournant essentiel. L'Église, par ses pasteurs, veut que les chefs chrétiens laïques se mettent à l'œuvre pour incarner dans des institutions nouvelles le message permanent du Christ, - ce qu'ils sont en train de faire.

[p. 212]

Mais déjà, je touche à un second point, l'évolution du syndicalisme. L'on s'étonne que le syndicalisme catholique soit vigoureux depuis quelques années ; il applique les directives de l'Église enseignante. Notre syndicalisme, - que l'on me permette ce raccourci d'histoire - a d'abord été aussi national que catholique : il a été une réaction « anti », non pas anti-anglaise, mais antidomination extérieure et anti-mentalité d'affaires. Notre syndicalisme, en effet, dans plusieurs régions de la province de Québec, est né avec la protection des Anglo-canadiens ou des Américains industriels. Ceux qui s'intéressent à l'histoire des mouvements sociaux devraient analyser pourquoi les Canadiens français, à la fin du $\mathrm{XIX}^{\mathrm{e}}$ siècle, ont été beaucoup plus favorables aux Chevaliers du Travail qu'à la Fédération américaine du Travail, au point d'être les derniers à faire partie de ces Knights of Labour alors pratiquement disparus des États-Unis et du Canada anglais. Aussi les Canadiens français sont-ils restés fidèles à cette tradition où il y avait beaucoup plus de mystique et de doctrine que dans le syndicalisme purement d'affaires de l'A.F. of L. Comment s'étonner qu'au Lac-Saint-Jean, où a commencé le syndicalisme, et ailleurs, la réaction vigoureuse se soit faite contre une main-mise sur les hommes ? Les Canadiens français se sont résignés à ce que les Anglo-Canadiens aient la main-mise sur les richesses; ils n'ont jamais accepté la main-mise sur euxmêmes, sur leur vie sociale. Toute notre histoire depuis cent cinquante ans le révèle. Quoi qu'il en soit, plutôt que d'accepter une main-mise extérieure, ils ont d'abord accepté des « unions de compagnies », car il faut bien reconnaître que la majorité des premiers syndicats nationaux catholiques furent pratiquement des unions de compagnies, favorisées par les industriels qui ne voulaient pas du syndicalisme d'outre-frontière.

J'ai assisté à l'évolution de ce syndicalisme original, notamment dans un endroit caractéristique qui est sous plus d'un aspect intéressant parce que maintenant bien connu : à Asbestos. J'ai connu là un syndicat qui ressemblait

civile de Québec; dans la collection «Les documents sociaux», série : Chrétienté d'aujourd'hui, publiée par le Service extérieur d'éducation sociale, Faculté des Sciences sociales, Université Laval, Québec ; p. 32.

Op. cit., p. 13. 
fort à une union de compagnie. Avant de prendre une décision, l'on consultait le curé, ami des dirigeants de la compagnie. Le syndicat devait d'ailleurs son existence à une tractation clérico-patronale. Je l'ai connu alors que la cotisation mensuelle était de vingt-cinq sous. Mais voici que les chefs syndicalistes se sont peu à peu révélés et formés dans l'action. En fait, les unions de compagnies sont des « jeux [p. 213] dangereux » pour les compagnies, parce que le goût de l'union ou du syndicalisme s'y développe et que les ouvriers prennent peu à peu de la compétence. S'ils ont de l'étoffe et le sens de l'honneur, ils prennent de l'indépendance et du prestige. Aussi dans la province de Québec, les unions de compagnie de ce genre, doctrinales et sincères, établies un peu partout, se sont graduellement transformées, puis associées aux fédérations authentiques et solides.

Il me reste, en vue de ma conclusion, à marquer deux principaux tournants de l'histoire de notre syndicalisme catholique. Le premier débuta en 1941-42 par une vaste attaque des unions internationales contre le syndicalisme national. Un certain Robert Haddow, reconnu depuis comme communiste, avait pris la tête de ce mouvement dangereux et puissant et voulait effacer dans notre province le syndicalisme catholique. La réaction fut alors profonde : on était au temps du plébiscite sur la conscription. Elle se manifesta surtout au Lac-Saint-Jean et à Sorel. L'enquête Prévost avait révélé que la compagnie Price Brothers n'accepterait pas les Syndicats catholiques à moins qu'ils changent leur nom ou leurs principes, en somme, à condition qu'ils acceptent les non-Catholiques comme les autres. Après consultation entre autorités religieuses et syndicales, la politique des syndicats de Montréal se généralisa dans la province: les non-Catholiques furent reçus sur un pied d'égalité, mais la confessionnalité de principe fut maintenue, c'est-à-dire l'adhésion collective aux principes de la doctrine sociale de l'Église. À partir de ce moment, qui coïncida avec la mise en vigueur de la «Loi des relations ouvrières » de 1944, autre conséquence de cette même enquête au Lac-SaintJean, le mouvement syndical connut une étonnante prospérité.

Le deuxième tournant se prit à l'apparition d'un projet de loi qui s'est appelé le «Bill numéro 5 », qui voulait établir dans la province un Code du travail. Depuis quelques années, le clergé avait entrepris l'éducation des chefs syndicalistes qui enfin avaient l'occasion de se révéler. Ils se sont affirmés en instituant un «cartel» entre les confédérations syndicales de juridictions divergentes : Congrès des métiers du Canada, Congrès canadien du Travail et C.T.C.C.

J'explique ainsi l'importance de l'événement en me référant à l'histoire de notre pays. Au temps de Louis-Joseph Papineau, les [p. 214] Canadiens français se sont politiquement organisés seuls pour faire la réaction. Papineau, dont ce fut la vocation, au dire des historiens, de faire l'éducation politique des Canadiens français, laissa derrière lui une équipe d'hommes qui pouvaient mener la lutte avec vigueur et compétence, s'associer aux Anglo-Canadiens sans être absorbés. C'est ce qui permit à Lafontaine de prendre la tête du mouvement de réforme et de constituer un cartel qui fut le ministère Lafontaine-Baldwin. Enfin commençait en politique la collaboration avec les Anglo-Canadiens, mais une collaboration dans l'égalité, la dignité, la 
reconnaissance des droits mutuels et dans la revendication d'un progrès politique commun: ce fut bientôt la conquête de la responsabilité ministérielle. Or, ce qui s'est réalisé sur le plan politique de 1841-1848 s'est réalisé ici sur le plan social en 1949, Le monde ouvrier canadien-français n'ayant pas encore été éduqué sur le plan social et économique et n'ayant pas suffisamment de chefs, ne s'était pas risqué à collaborer avec les AngloCanadiens parce que dans cette collaboration son syndicalisme propre aurait été écrasé. Quand il eut des chefs en nombre et de taille et quand ses cadres furent solides, il a de lui-même offert sa collaboration aux autres organisations ouvrières de la province de Québec. Ce fut le fameux cartel qui a modifié les relations entre les organisations ouvrières du pays et la structure même des relations patronales-ouvrières, au point d'en inquiéter aujourd'hui plusieurs qui réfléchissent dans le passé. Depuis ce moment-là les conquêtes s'accumulent : le dynamisme de nos organisations ouvrières est aujourd'hui un fait dans la province de Québec.

Je conclus. Le phénomène remarquable est que nous avons actuellement dans la province de Québec un cartel de syndicats .ouvriers, signe que les Canadiens français sur le plan social ne limitent pas leur horizon à leur nationalité et à leur province. Ce cartel correspond au cartel des patrons qui, depuis longtemps, s'associent par delà les barrières de province ou de nationalité. Considérons la grève qui s'est déroulée au printemps de 1952 à Montréal. Elle constitue une synthèse frappante de toutes les conséquences de l'évolution industrielle depuis 10 ans: un patron canadien-français, très nationaliste, se fait aider par des patrons non-canadiens-français pour soutenir une grève d'un syndicat national catholique, qui a commencé comme « union de compagnie » [p. 215] et qui est maintenant épaulé par des organisations ouvrières non-catholiques. Cet événement est typique de l'évolution de notre pensée sociale.

Je veux terminer sur une note optimiste, contrairement à M. Tremblay, peut-être trop pessimiste. Je suis convaincu qu'un milieu qui a créé des institutions comme celle dont je viens de décrire l'évolution est bien vivant. Nous avons eu, dans le domaine politique, un homme qui nous a précisé une doctrine : ce fut Henri Bourassa. Cette doctrine s'est aujourd'hui imposée au Canada tout entier. Elle est celle de tous les nationalistes canadiens et de tous les hommes politiques contemporains de quelque valeur. C'est une doctrine, comme l'a très justement remarqué $\mathrm{M}$. Mason Wade, à base d'indépendance nationale. Nous avons eu, dans le domaine culturel, une pensée qui s'est organisée avec de plus en plus de cohérence : ce fut l'œuvre de MM. Groulx et Montpetit. Nous avons enfin, dans le domaine économico-social, un homme qui nous a donné une pensée riche dans ses sources, forte dans ses cadres et adaptée dans sa méthode, c'est M. Esdras Minville. Aussi, notre monde social, en particulier notre monde syndical ouvrier, s'avance-t-il vers l'avenir avec plus de confiance, parce que ses chefs, conscients de leur force et de leur responsabilité, possèdent une doctrine sûre et claire qu'ils savent incarner dans la réalité. 
[p. 217]

\title{
CHAPITRE X
}

\author{
REGARDS SUR LE QUÉBEC
}

\author{
Everett Cherrington Hughes
}

\section{$\underline{\text { Retour à la table des matières }}$}

Je me sens honoré, sans être tout à fait surpris, de participer à ce symposium. C'est en effet l'une des gloires de notre profession consacrée à l'étude de l'homme de grouper tous ceux qui s'y adonnent en une fraternité qui transcende les frontières entre les langues et les nationalités. Nous n'atteignons le plan authentique de la science que dans la mesure où, dans nos recherches et nos dialogues entre collègues, nous parvenons à dépasser ces frontières.

Les réflexions que je veux soumettre au terme de cette discussion « de famille » des problèmes québécois prendront peut-être plus de signification si j'indique sommairement certaines circonstances historiques qui les ont déterminées et la perspective dans laquelle elles furent élaborées. Si c'est un heureux concours de circonstances qui me rapproche encore une fois de l'Université Laval, je dois aussi à un heureux enchaînement de hasards d'avoir été amené jadis à enseigner dans une université canadienne comme d'avoir été entraîné à observer de près la vie canadienne-française contemporaine. Au point de départ, j'eus la bonne fortune, comme étudiant et candidat au doctorat en sociologie et en anthropologie à l'Université de Chicago, d'avoir comme principal maître le regretté professeur Robert E. Park. Son enseignement a profondément marqué les étudiants de ma génération. De ses innombrables observations toujours pénétrantes, je devais en particulier retenir la notion que les « laboratoires » humains les plus fascinants pour le chercheur social sont les pays ou les régions du monde où cohabitent des groupes sociaux d'origine ethnique ou culturelle différente. C'est aussi le professeur Park qui, au terme de mes études, me dirigea vers l'Université McGill de Montréal où l'on venait d'instituer un département de [p. 218] sociologie. Au moment où je le quittai, il me rappela deux conseils qui devaient me guider durant mon séjour au Canada. Le premier était de ne jamais enseigner de sujet qui ne me permît d'apprendre moi-même quelque chose de nouveau, - car, disait-il, si vous tentez d'enseigner sans vouloir en même temps apprendre, l'ennui s'emparera 
de vous et des étudiants. Le second conseil était d'identifier, dans le milieu où j'allais vivre, le problème social le plus marquant et d'en aborder l'analyse. Montréal, agglomération humaine par ailleurs si complexe et si attirante, m'imposait un choix facile : quel sujet plus passionnant, en effet, que celui des relations entre les deux principaux groupes ethniques composant la nation canadienne, les Canadiens de langue française et ceux de langue anglaise ?

C'est ainsi que je fus absorbé par la vie canadienne et que j'en vins à consacrer une phase heureuse de ma carrière à l'étude des relations entre Canadiens français et Canadiens anglais. Or, l'observateur qui aborde l'analyse des relations inter-ethniques a le choix entre diverses méthodes, ou plus exactement, entre diverses optiques que lui propose la littérature sociologique contemporaine. Tout compte fait, ces optiques se ramènent à deux principales : ou bien l'observateur prendra comme hypothèse que l'évolution normale des relations entre deux groupes ethniques consiste dans un processus d'« assimilation » inévitable de l'un par l'autre ; ou bien, il considérera chacun des groupes comme une entité culturellement homogène et tentera de comprendre les relations de l'un avec l'autre dans la perspective de leur histoire et de leur ambition respectives.

Le premier mode d'analyse se fonde sur l'observation de la façon dont les deux grands pays de l'Amérique du nord, les États-Unis et le Canada, se sont développés au cours $\mathrm{du} \mathrm{XIX}^{\mathrm{e}}$ siècle et à notre époque. Ces pays furent colonisés par des contingents successifs d'immigrants venus d'Europe, d'Afrique et d'Asie. Dès qu'un groupe de nouveaux venus s'étaient établis, on pouvait observer le processus graduel de leur « américanisation» ou de leur «canadianisation. » On prévoyait en général qu'après un certain temps ils deviendraient "assimilés " et perdraient les caractères distinctifs de la civilisation de leur pays d'origine. Tout naturellement, l'étude de ce processus d'assimilation des immigrants devint l'une des préoccupations principales des sociologues américains. Je puis [p. 219] ajouter en toute franchise que ceux de mes collègues de l'Université McGill qui s'intéressaient tant soit peu au Canada français contemporain étaient inconsciemment portés à le considérer ainsi comme une entité en voie d'assimilation. Le postulat de leurs réflexions était que les Canadiens français seraient tôt ou tard absorbés, en tant que groupe ethnique, dans le grand tout canadien de langue anglaise. J'adoptai malgré moi ce point de vue au début, mais je me rendis compte, après quelque temps, que je devais complètement rejeter la conception que les Canadiens français, comme groupe, étaient destinés à subsister moins longtemps que leurs compatriotes de langue anglaise.

La seconde manière d'envisager les relations de deux groupes ethniques est de noter, comme c'est souvent le cas, que l'un des groupes constitue par rapport à l'autre une minorité culturelle qui a ses propres raisons de vivre associées à des traditions et à des institutions autonomes. Une telle minorité peut même constituer le groupe des premiers occupants d'un pays. L'histoire en a fait un groupe politiquement dominé par un peuple d'« envahisseurs » ou de «conquérants. » Mais cette minorité n'en perd pas pour autant, bien au contraire, son désir de survivre et de s'affirmer. Elle forme une enclave culturelle dans un pays à la vie duquel elle veut participer de façon originale. 
C'est le cas du Canada français. Néanmoins, je dus aussi constater très tôt que le phénomène le plus frappant dans l'aventure du Québec d'aujourd'hui était l'invasion de l'industrie. Ce fait nouveau devait immanquablement transformer les principaux caractères de la vie canadienne-française et la nature des relations traditionnelles entre les Canadiens français et leurs compatriotes de langue anglaise. Pour autant, déjà familier avec les ouvrages d'Henri Bourassa et de l'abbé Groulx, je concentrai plutôt mon attention sur le développement des industries québécoises, sur le syndicalisme ouvrier et sur la division du travail social entre Canadiens anglais et Canadiens français. Je relus les encycliques sur la question ouvrière et l'histoire du mouvement ouvrier catholique en Allemagne. Par ces lectures, j'appris qu'en Rhénanie catholique, depuis le milieu du $\mathrm{XIX}^{\mathrm{e}}$ siècle, des entrepreneurs protestants avaient établi des industries de type moderne en des régions rurales d'où ils avaient tiré leur main-d'œuvre. Ni l'aristocratie des grands propriétaires terriens catholiques, ni les hommes d'affaires [p. 220] ou les professionnels catholiques des grandes villes, y compris Cologne, ni les artisans catholiques des bourgs et des villages n'avaient joué de rôle important soit dans le financement, soit dans l'établissement, soit dans l'organisation technique de ces entreprises. Dans presque tous les cas, ces fonctions avaient été remplies par des Protestants du nord de l'Allemagne; dans l'industrie de l'acier, les initiateurs avaient été des ingénieurs d'Angleterre ou de Belgique, pays où avaient été inventés et mis au point les procédés de fabrication de l'acier. C'était là une situation ressemblant fort à celle du Québec du $\mathrm{XX}^{\mathrm{e}}$ siècle. Je décidai d'aller l'observer sur place et j'allai passer une année en Allemagne. Je devais en rapporter des observations et des questions qui peuvent nous permettre de comprendre certains problèmes actuels de la province de Québec.

\section{CARACTÈRES DE L'INDUSTRIE MODERNE}

Ces questions peuvent sembler banales mais elles nous incitent à saisir certains aspects essentiels de l'industrie moderne. Par exemple : «D'où vient qu'à notre époque ce sont certains peuples, et non certains autres, qui ont pris l'initiative de fonder des industries? Quelle variété de formes l'industrialisation a-t-elle prises et quelle variété de conséquences a-t-elle engendrées dans les divers pays où elle s'est produite ? Quelles similitudes retrouve-t-on dans les régions ou chez les peuples récemment industrialisés? Selon quelles étapes une société ou un peuple encore peu développés s'adaptent-ils à un mode de vie fortement industrialisé ? » Je n'aurai pas la prétention de répondre à toutes ces questions inextricablement liées les unes aux autres mais je voudrais seulement noter quelques-uns des problèmes sociologiques qu'elles soulèvent.

Il semble que dans presque toutes les sociétés maintenant industrialisées la grande industrie ait été implantée par des «étrangers.» L'Angleterre, la Nouvelle-Angleterre, certaines régions de l'Europe occidentale et le Japon sont des exceptions. La province de Québec, à cet égard, suit la règle commune. Le 
Center for Entrepreneurial History de l'Université Harvard a justement entrepris d'étudier par quel concours de circonstances la Nouvelle-Angleterre a trouvé en elle-même le ferment de sa propre industrialisation.

[p. 221]

Comment se fait-il, par exemple, que les hommes d'affaires de cette région aient graduellement abandonné le commerce pour se tourner du côté de l'industrie ? Comment se fait-il que la Nouvelle-Angleterre ait non seulement trouvé sur place les chefs et les techniciens qui devaient assurer sa prestigieuse expansion industrielle mais qu'elle ait aussi produit ceux qui devaient essaimer sur tout un continent? Les travaux du professeur Robert Lamb du Massachusetts Institute of Technology ont montré qu'à l'origine de chacun de ces essors industriels de l'Est américain, on retrouve généralement la présence et la coopération intime de deux types d'hommes : l'homme d'affaires bien informé des marchés domestiques et internationaux, l'ingénieur à l'esprit inventif et discipliné. Considérant la vie économique du Canada à la même époque, demandons-nous par ailleurs comment il se fait que les Canadiens anglais de la vallée du Saint-Laurent se soient intéressés presque exclusivement au commerce tout en laissant les Canadiens français établir et diriger les petites industries du moment? Pourquoi, par la suite, l'essor des industries de type nouveau fut-il déterminé par d'autres que les Canadiens français? Je connais quelques-unes des réponses proposées comme explications. L'une de celles que l'on invoque souvent est d'ordre religieux : on allègue que le capitalisme est protestant. Mais des exemples différents viennent aussitôt à l'esprit. Ainsi, dans le sud des États-Unis, les Catholiques sont plutôt rares. Or, là aussi c'est la population locale qui a établi les premières petites industries tout en maintenant une forme de civilisation qui reconnaissait un grand prestige social à l'avocat et au médecin plutôt qu'à l'ingénieur. Plus tard, elle laissa les Américains du nord apporter chez elle les grandes industries. On ne peut davantage expliquer l'absence initiale des Canadiens français de la grande industrie par un manque d'aptitudes techniques, car depuis longtemps la France, sans avoir connu de Henry Fords, a produit de grands ingénieurs. Comment donc aborderons-nous la réponse ?

$\mathrm{Au}$ fait, je n'ai peut-être pas posé dans ses justes termes la principale question qui nous intéresse. Nous nous demandons en effet : « D'où vient que certaines sociétés s'industrialisent elles-mêmes tandis que d'autres attendent l'invasion de capitaux, de gérants et de techniciens étrangers ? » Or, nous savons qu'en général lorsqu'une industrie naît quelque part, elle y est établie [p. 222] par des techniciens venus d'ailleurs, des grands centres industriels déjà existants. Ceci est vrai des villes de l'Iowa comme de celles de la province de Québec. Si, dans une ville de l'Iowa, une fabrique de montres est mise sur pieds par une compagnie de l'Est américain, l'outillage, le gérant et les techniciens de l'entreprise seront amenés de l'extérieur, car ils constituent en quelque sorte des pièces interchangeables du système industriel. Les hommes d'affaires et les professionnels locaux n'auront pas plus de rôle à jouer dans l'établissement et la direction de cette industrie que ceux d'une petite ville du Québec. Il y a cependant entre les deux cas une différence importante : les fils des hommes d'affaires et des professionnels de la ville de l'Iowa 
fréquentent en grand nombre les Écoles de génie et, une fois diplômés, ils passeront dans la catégorie sociale des «fonctionnaires itinérants" de l'industrie moderne. On les retrouvera bientôt à la tête d'une usine, soit dans leur ville natale, soit dans une autre ville américaine, peut-être au Canada. Au contraire, les fils des avocats et des notaires de la localité canadienne-française de Cantonville que j'ai étudiée jadis ne se dirigent pas encore en très grand nombre vers les Écoles de génie. Les statistiques rapportées en d'autres études de ce symposium semblent indiquer que la ré-orientation professionnelle de la nouvelle génération est encore assez lente. Les jeunes Canadiens français ne se sont pas laissés et ne se laissent pas encore facilement attirer par les carrières industrielles. Nous comprendrons peut-être un peu mieux pourquoi si nous considérons un autre des aspects les plus caractéristiques de la société industrielle moderne.

Le phénomène dont je veux parler se retrouve en d'autres institutions que l'industrie et je le définirais comme la «circulation des techniciens». L'industrie moderne, et je songe surtout aux grandes entreprises qui possèdent des filiales éparpillées en diverses régions, fait voyager ses jeunes techniciens d'une usine à l'autre. L'avancement professionnel de ces jeunes s'effectue non pas tant par le passage hiérarchique d'une charge à une autre au sein d'une même usine que par le passage d'une usine à une autre, d'une ville à une autre, voire, d'un pays à un autre. Un grand nombre de spécialistes à l'emploi de compagnies de types divers suivent une trajectoire similaire, passant, au cours de leur carrière, d'une compagnie à une autre, de ville en ville, accomplissant partout et constamment les mêmes fonctions. Le technicien ou le spécialiste [p. 223] itinérant joue ainsi un rôle considérable dans l'industrie moderne. On retrouve ce personnage dans d'autres sphères de la vie sociale, dans les affaires, dans les grands hôpitaux, dans les universités. Il doit être un homme entreprenant, mais il n'est pas un "entrepreneur » au sens classique du mot. Son entreprise, c'est sa carrière personnelle. Dans la majorité des cas, il demeurera toute sa vie un employé salarié.

Ainsi la vraie question que nous avons à nous poser n'est pas : « D'où vient que certaines sociétés fondent des industries, et d'autres, pas ? " mais plutôt : « D'où vient que certains individus ou certains groupes d'individus sont attirés par la profession itinérante des techniciens et des gérants d'industrie, et d'autres pas ? "Si l'on veut préciser la portée de cette question, on peut ajouter : «Dans quelle proportion les jeunes d'une société donnée embrassentils cette profession itinérante? Dans quelle orbite géographique et sociale circulent-ils?» Et nous touchons ici le cas particulier du Canada français. 


\section{LES CANADIENS FRANÇAIS DANS L'INDUSTRIE}

Tous reconnaissent que les Canadiens français n'ont pas encore abordé en grand nombre les professions itinérantes de l'industrie. À tout le moins, leur intérêt pour ces professions est encore loin de se comparer à leur intérêt pour les professions sédentaires du droit et de la médecine dont la pratique exige une clientèle stable dans une ville ou une localité donnée. Ceux d'entre eux qui choisissent le génie semblaient, il y a encore quelques années (du moins si j'en crois les observations d'amis canadiens), ambitionner des carrières de type bureaucratique pour le compte des municipalités ou du gouvernement. J'ignore quelles sont les tendances actuelles mais elles demanderaient sûrement à être étudiées de près.

Le fait important à noter est que ces carrières d'ingénieur bureaucrate permettent au jeune Canadien français de circuler et de demeurer parmi les « siens ». Les carrières d'ingénieur ou d'administrateur industriel exigent, au contraire, le déplacement et la circulation dans une orbite beaucoup plus vaste qui déborde les frontières culturelles et souvent les frontières nationales. Or, de telles exigences posent un problème crucial pour une collectivité [p. 224] dont la langue et la culture sont différentes de celles du reste du continent nord-américain car, si des membres de cette collectivité veulent « suivre » leur carrière partout où celle-ci les conduira, ils se retrouveront tôt ou tard en des lieux où cette culture est en danger. Je ne veux pas dire qu'il n'existe pas de carrières exigeant une haute compétence technique qui peuvent être suivies jusqu'au bout sans que l'on ait à sortir de son milieu. Je ne méconnais pas non plus le bien-fondé de la préférence normale que peuvent avoir beaucoup de chefs d'industrie pour des assistants ou des techniciens de leur propre groupe ethnique. Mais, à mon avis, le fait que l'univers social canadien-français constitue une portion très restreinte du vaste univers industriel nord-américain doit influencer de façon subtile la conception que le jeune Canadien français se fait de sa carrière. Il ambitionnera vraisemblablement d'être entrepreneur plutôt que très entreprenant. (On me rappellera peut-être que l'on engage de plus en plus les Canadiens français pour des postes élevés dans l'industrie, par exemple, comme directeurs de personnel ou agents de relations publiques. Ces faits nouveaux ne modifient pas substantiellement les courants de base, car il s'agit là d'occupations qui consistent généralement à assurer la liaison entre des employeurs ou des gérants de langue anglaise et des employés de langue française. Ce sont des occupations intéressantes et nécessaires mais elles n'ont rien à voir avec la direction ou l'exploitation technique des entreprises industrielles.)

Il y a de « grandes » et de « petites » sociétés, si l'on entend «petite» par rapport au volume de la population et à l'éventail des carrières professionnelles disponibles tout autant que par rapport à la surface du territoire habité. Or, nous connaissons encore mal la psychologie profonde de l'individu qui est membre d'une petite société. Le Canadien français ne peut pas, sans risque 
pour son identité ethnique, aller aussi loin hors de son milieu que le Canadien anglais ; ce dernier, à son tour, ne peut pas aller tout à fait aussi loin que l'Américain. Personne, à ma connaissance, n'a encore étudié les répercussions de ces phénomènes sur le caractère national des Canadiens français ou de quelque groupe ethnique que ce soit. Je voudrais, à ce point, proposer de nouveau, comme je l'ai fait il y a quelques années-en une autre occasion, un projet de recherches qui consisterait à recueillir des récits autobiographiques de jeunes Canadiens français et à tâcher de retracer ce que [p. 225] sont leurs conflits intimes et leurs inquiétudes; leurs rêves et leurs cauchemars ; l'idée qu'ils se font d'eux-mêmes, de leurs aînés et aussi des gens de langue anglaise qu'il leur est arrivé de rencontrer. J'estime que les chercheurs sociaux ne devraient pas, en ce domaine, se laisser devancer par les romanciers, bien qu'ils auront toujours besoin de l'apport des romanciers pour en arriver à saisir ce qu'est l'homme et ce qu'est la société.

Je sais que j'aborde ici un domaine très délicat mais c'est généralement à ces frontières que l'on fait les découvertes les plus riches. À mon avis, on ne parviendra jamais à comprendre le sens profond de la division fondamentale $\mathrm{du}$ travail social entre Canadiens français et Canadiens anglais dans la province de Québec, ni de leur répartition respective par types d'occupations, tant que l'on n'aura pas analysé en profondeur ce qui se passe dans l'esprit des jeunes. Il se peut même qu'en définitive certaines différences fondamentales que l'on discerne entre les types de personnalité qui prévalent d'un groupe ethnique à l'autre, en ce pays comme à travers le monde, tiennent à la façon dont se sont intégrées, dans l'expérience individuelle, des influences aussi lointaines et diverses que le style de vie familiale, les normes des relations entre hommes et femmes, les modalités des contacts entre les générations au sein de la famille, d'une part, et entre l'individu et sa famille, d'autre part. C'est ainsi qu'on pourrait rattacher à l'un ou l'autre ou à l'ensemble de ces facteurs des dominantes psychologiques telles que le goût de l'aventure ou le désir de la sécurité ; la tendance à la stabilité ou le besoin du mouvement ; l'aptitude à découvrir et à créer toujours du neuf ou la patiente détermination à perfectionner une œuvre entreprise ; l'inclination vers l'art ou la poursuite des recherches scientifiques.

Je reviens à la distinction entre les professions itinérantes et les professions sédentaires. Toutes les institutions qui comptent un grand nombre d'établissements répartis sur un vaste territoire comportent ces deux types de professions. L'Église catholique, depuis des siècles, a eu son clergé itinérant. La profession académique est aussi itinérante. Néanmoins, dans un milieu culturel aux frontières restreintes comme le Canada français, cette dernière profession ne peut pas être très itinérante. Le Québec ne compte que deux universités françaises, trois, si l'on inclut celle d'Ottawa. En conséquence, un jeune homme qualifié qui, en 1953, serait prêt [p. 226] à enseigner une science quelconque dans l'une ou l'autre de ces deux ou trois universités aurait très probablement à attendre, avant de pouvoir réaliser son ambition, qu'un professeur aîné lui laisse la place au moment de la retraite. Cela pourra prendre des années. Il sera peut-être obligé, en attendant, de gagner sa vie de quelque autre façon. Peut-être devra-t-il abandonner complètement son rêve. 
Ces remarques nous amènent à considérer le degré de spécialisation que peut se permettre l'enseignement universitaire dans une petite société. Loin de nous écarter du problème de l'industrialisation, nous en toucherons ainsi un autre aspect capital. En effet, les universités du monde occidental ont dû s'adapter, à des degrés divers, aux exigences de l'industrie moderne qui réclamait des spécialistes compétents dans les domaines les plus variés du savoir technique, économique et social. Une telle spécialisation, à son tour, exige un vaste marché du travail, c'est-à-dire, la possibilité d'une vaste circulation des jeunes gens destinés à l'industrie. Ceux-ci, à la fin de leurs études, sont prêts à aller partout où les attendent des postes correspondant à leur formation technique. C'est, depuis toujours, une question fort épineuse pour toute université de déterminer quel degré de spécialisation elle doit offrir à ses étudiants. Pour une université pourvoyant aux besoins d'une petite société, c'est une question particulièrement vitale. Elle ne peut supporter le fardeau d'un enseignement spécialisé dans tous les domaines du savoir. Bien plus, le marché du travail qui s'offre à ses gradués n'est pas assez vaste pour inclure toutes les variétés de spécialisations scientifiques. Or, c'est un fait paradoxal que, juste au moment où le Québec connaît l'industrialisation et l'urbanisation massives de son histoire et que ses universités se tournent vers la spécialisation, les universités américaines, surtout celles des régions les plus industrialisées (y compris une institution telle que le Massachusetts Institute of Technology), sont en train de réagir contre leur ancienne tendance à la spécialisation extrême. Voici, par exemple, en quels termes M. Chester Barnard s'adressait à un groupe d'étudiants de l'École de commerce de Chicago : « N'ambitionnez pas, disait-il, d'apprendre à l'université les systèmes de comptabilité dernier cri. La compagnie pour laquelle vous travaillerez plus tard aura son propre système et, quoi que vous fassiez, vous aurez à l'apprendre sur place. [p. 227] Apprenez plutôt les principes généraux de la comptabilité et tâchez d'apprendre quelques principes des autres sciences. Tâchez aussi d'acquérir quelques notions de ce que sont les structures de la vie sociale et de la façon dont les hommes s'y comportent. À tout prendre, les techniques spécialisées changent trop vite pour être enseignées dans les écoles et les universités ...»

Pour ma part, je ne sais pas quel degré de spécialisation les universités du Canada français peuvent ou doivent se permettre. Mais je crois qu'on devrait étudier ce problème avec attention en tenant soigneusement compte à la fois des possibilités réelles, du marché du travail professionnel et des carrières que les jeunes choisissent effectivement au sortir de l'université. Remarquons en passant qu'en général les Écoles de commerce ne forment pas des directeurs ni des gérants d'entreprises mais plutôt les fonctionnaires subalternes du commerce et de l'industrie. Elles préparent des bureaucrates plutôt que des chefs ou des créateurs. La même destinée guette facilement les Écoles de génie : elles pourront se contenter de produire de bons assistants aptes à reproduire fidèlement les plans des autres plutôt que de former ceux qui trouvent les idées nouvelles et inventent les plans. Je sais que de grands changements sont en train de se produire dans les universités du Canada français et que de plus grands encore sont à l'étude. Quelques-uns de ces changements ont comme objectif de préparer les jeunes pour des postes plus 
élevés dans l'industrie et pour des carrières consacrées au bien-être des ouvriers ou des populations des petites villes industrielles et des grandes agglomérations urbaines de la province. Mais ce serait dommage que ces innovations prennent exemple sur des modèles déjà périmés dans des régions depuis longtemps industrialisées. $\mathrm{Si}$, en d'autres pays, des programmes d'orientation professionnelle ont été élaborés pour adapter le système d'enseignement aux exigences de la vie industrielle, le Québec ferait bien, avant de s'en inspirer, de vérifier s'ils ont atteint leurs objectifs. L'un des privilèges des benjamins du monde industriel est de pouvoir éviter les erreurs des aînés. L'adaptation des institutions d'enseignement du Québec aux carrières industrielles doit se baser sur les réalités actuelles ou prévisibles du Québec et non sur des expériences infructueuses de l'étranger, que ce soit celles de l'Angleterre ou de la Nouvelle-Angleterre.

$$
\text { [p. 228] }
$$

Un des mythes de la sociologie du travail dans les pays depuis déjà longtemps industrialisés est que tout individu doit se choisir une carrière très spécialisée, en faire l'apprentissage, et s'y adonner exclusivement le reste de sa vie. L'espèce de mentalité de comptable qui domine les employeurs et les employés du monde industriel moderne fait que les uns et les autres se sentent mal à l'aise si l'occupation de tout salarié n'est pas étiquetée, définie, classifiée et identifiée par une rémunération précise. Ce mythe n'a pu se perpétuer que grâce à d'autres fictions que l'on a inventées, au fur et à mesure, pour rendre compte des cas imprévus. Par contre, dans les petites sociétés où le degré de spécialisation des occupations est moindre, un même individu, encore de nos jours, peut poursuivre simultanément deux carrières dont chacune est rémunératrice, ou même être désigné du nom d'une profession tout en exerçant les activités d'une autre. En d'autres termes, il est loin d'être prouvé que le mode d'organisation et les étapes typiques des diverses carrières sociales doivent être les mêmes dans les petites et les grandes sociétés. Des recherches récentes en organisation industrielle ont montré qu'un grand nombre de spécialisations techniques modernes originairement considérées comme nécessaires n'avaient été, en dernière analyse, que l'expression d'un besoin de spécialisation à tout prix. Les hommes, enivrés par leur propre faculté d'invention dans le domaine technique et bureaucratique, ont poussé les inventions bien au-delà du degré de rendement optimum. Depuis quelques années, un contre-courant se dessine dans le but de simplifier les structures industrielles et de réduire le nombre des emplois spécialisés à l'intérieur de ces structures. Peut-être le monde de la grande industrie est-il en voie, sous ce rapport, de rattraper le Québec. Si tel est le cas, il serait dommage de voir le Québec, au même moment, tenter lui-même de rattraper le monde de la grande industrie. 


\section{L'INDUSTRIE DU QUÉBEC DANS L'HISTOIRE DU CAPITALISME}

Une dernière remarque pour terminer. S'il est vrai que les sociétés ont subi l'industrialisation selon des modalités diverses, elles ont aussi subi cette expérience à des moments différents de l'histoire, et ceci sous un double rapport: par rapport à leur propre histoire, et par rapport à l'histoire de l'industrie elle-même. D'une [p. 229] part, toute société, au moment de son industrialisation, en était à un certain stade de son évolution matérielle et spirituelle. D'autre part, l'industrie moderne a eu sa propre évolution : certains pays ont été industrialisés au moment où le capitalisme était encore jeune et ambitieux; d'autres, à une époque où il était vieilli, transformé dans son esprit et dans sa structure. C'est le sort du Québec de connaître sa gigantesque expansion industrielle à un moment où le capitalisme, déjà parvenu à un âge avancé, n'est plus, comme jadis, l'aventure hardie de petits groupes d'hommes entreprenants mais un encerclement colossal, inéluctable, d'institutions impersonnelles. Dans ces conditions nouvelles, le gérant d'entreprise moderne s'est métamorphosé en un homme généreux, souvent préoccupé du bien-être des ouvriers ou de la société, mais dominé et écrasé par le système industriel dont il n'est qu'un instrument. L'époque est révolue où d'immenses fortunes pouvaient s'édifier dans l'industrie. Même le salaire actuel d'un demi-million de dollars que reçoit annuellement le président de la General Motors n'est rien à comparer à la fortune d'un John D. Rockefeller. Un signe manifeste de changement apparaît dans le fait que les œuvres philanthropiques reçoivent maintenant leurs dons importants beaucoup plus des grandes compagnies que des individus.

Schumpeter a noté que le nouvel industrialisme ne produit plus de ces dynasties familiales qui contrôlaient de vastes empires industriels. Il produit au contraire ce que l'appellerais « la confrérie des hommes prospères », c'est-àdire, de ces hommes entreprenants qui consacrent avec succès toute leur vie et leurs talents au service des grandes institutions industrielles. À la lumière de ces données, il est probablement juste d'affirmer que la structure des classes sociales n'est pas la même dans les sociétés qui se sont industrialisées à un moment tardif de leur histoire et de l'histoire du capitalisme et dans les sociétés qui se sont industrialisées alors qu'elles étaient très jeunes et que le capitalisme lui-même était encore dans son enfance.

Pour autant, si on me permet une autre suggestion, je proposerais aux chercheurs sociaux du Québec de scruter cette autre question capitale, à savoir: quelles conséquences particulières ont résulté, pour la société canadienne-française, du fait de son industrialisation tardive? On retrouvera peut-être de ces conséquences [p. 230] aux paliers les plus imprévus de la société. Ce qui importe avant tout est que les observateurs de la vie 
économique, sociale et politique du Québec oublient, dans leurs recherches, ce qu'ils ont pu retenir des analyses et des interprétations portant sur les sociétés qui ont été les pionnières de l'industrialisme moderne. Qu'ils partent à neuf, libres de toute idée préconçue et de tout postulat livresque, pour tâcher de voir et de comprendre lucidement ce qui se passe autour d'eux, dans leur société.

Everett-C. HUGUES 
[p. 231]

\title{
CHAPITRE XI
}

\section{CONDITIONS DE NOTRE AVENIR}

\author{
Esdras Minville
}

$\underline{\text { Retour à la table des matières }}$

Afin de me mettre le mieux possible dans l'esprit de ces discussions de l'un des plus importants faits sociaux de notre milieu, j'ai cru nécessaire de retourner aux quelques ouvrages sociologiques qui ont été consacrés jusqu'ici au fait canadien-français. J'ai d'abord relu en entier le livre que le professeur Everett-C. Hughes publiait, il y a quelques années, sur une petite ville de notre province devenue, au cours des vingt-cinq ou trente dernières années, un centre industriel important. J'ai éprouvé à nouveau l'impression ressentie à la première lecture, savoir, que c'est là une sorte de photographie des reclassements qui s'effectuent dans la population et des modes nouveaux selon lesquels s'établissent les relations quand une grande industrie, appartenant à des maîtres étrangers, vient s'établir au sein d'une agglomération canadiennefrançaise. Par son objectivité, la précision de ses méthodes, l'étendue et l'exactitude de son information, cet ouvrage demeure encore un instrument de travail nécessaire à quiconque veut comprendre le problème social comme il se pose désormais dans notre province, surtout sous l'angle des relations ethniques.

J'ai ensuite parcouru rapidement le Saint-Denis de Miner, histoire de constater encore une fois comment réagit un homme de l'extérieur au spectacle de nos manières traditionnelles de vivre, de concevoir et de pratiquer la vie sociale. Puis, je suis remonté au vieux et toujours actuel Léon Gérin : Le type économique et social des Canadiens, Aux sources de notre histoire.

Avec Hughes, Miner et Gérin, j'ai donc relu ou feuilleté à nouveau les principales études scientifiques consacrées jusqu'ici aux problèmes sociologiques du Canada français. En tout, quatre volumes. Si l'on considère la valeur intrinsèque de chacun d'entre eux, on peut dire que c'est quelque chose, même beaucoup. Mais si l'on considère l'étendue et la complexité du 
phénomène à étudier, [p. 232] ainsi que la rapidité avec laquelle il se modifie et se propage sous nos yeux, il faut bien admettre que c'est peu, beaucoup trop peu. Bien des enquêtes et des recherches à longue portée demeurent à entreprendre qui seraient absolument indispensables à l'élaboration d'une politique économique et d'une politique sociale adaptées aux besoins de notre population.

L'industrialisation est certainement le phénomène dominant de notre époque, la cause la plus profonde et la plus agissante de l'évolution, disons mieux, de la révolution sociale dont nous sommes à la fois les témoins et l'objet. Mais pour comprendre ce phénomène, en mesurer la portée et la gravité, il ne suffit pas de l'observer de l'extérieur et d'en décrire la marche. Il faut tâcher de le voir par le dedans, c'est-à-dire ne pas se contenter de dégager les faits, de les classer, d'en deviner l'interdépendance, mais chercher à saisir la pensée qui les anime et les interpréter à partir d'une pensée plus haute, tenue elle-même comme étant la véritable loi de l'homme.

La révolution industrielle concerne tous les peuples occidentaux, c'est-àdire tous les peuples dont le régime social est en somme issu de la même conception générale de l'homme et de ses relations avec la société. Elle les concerne tous par la diffusion même des techniques qui, en révolutionnant le travail lui-même et la production, ne peuvent pas ne pas modifier l'attitude des hommes envers l'une des données les plus impératives de leur existence. Elle les concerne surtout par l'esprit qui, jusqu'ici, a animé l'usage des techniques et qui, lui, transforme le régime de travail, celui de la famille, de la propriété, les modes de vie, tendant du même coup à modifier jusqu'aux modes de pensée. Au bout de l'évolution en cours, il peut y avoir ou bien un homme libéré, c'està-dire soustrait aux servitudes de la matière, ou un robot, c'est-à-dire un homme assujetti aux techniques elles-mêmes. Dans le premier cas, le progrès économique aura été une conquête ; dans le second, une immense tromperie. Tous les peuples de même filiation culturelle, humaniste et chrétienne, ont donc à fournir le même effort de pensée s'ils veulent profiter des avantages que les progrès scientifiques leur apportent, sans perdre le sens des valeurs de vie infiniment plus précieuses qu'ils doivent à leur civilisation traditionnelle. Humaniser les techniques, humaniser l'économie, redéfinir la société à partir de l'homme et redéfinir l'homme à partir de sa loi : tel est le devoir de l'heure.

[p. 233]

Ce devoir s'impose aux nations occidentales, ai-je dit, pour deux raisons capitales : parce que leur existence même est en jeu en tant que détentrices séculaires de la seule formule humaniste qui véritablement colle à son objet, l'humanisme chrétien ; parce qu'elles assument, du fait même de l'histoire, des responsabilités envers les autres nations. Les conditions techniques de l'unité du monde sont réalisées. D'ici un siècle, moins peut-être, les peuples vivront à la surface du globe comme les familles d'un même quartier si, du jour au lendemain, elles devaient s'abriter sous un même toit. À cette unité matérielle doit correspondre une unité spirituelle. Sous l'empire de quelle philosophie s'opérera-t-elle ? Il est facile de dégager les véritables données de l'option. Or, en face d'un Occident ébranlé, tourmenté, inquiet, s'ouvre l'Orient mystérieux, décidé à sortir de son espèce d'immobilité millénaire et dans l'énorme 
complexe duquel se développent des forces et s'exercent déjà des pressions dont l'explosion pourrait avoir pour le monde des conséquences dont il est proprement impossible à un esprit humain d'imaginer d'avance la profondeur et l'étendue. Or, cet Orient qui n'a pas connu encore le christianisme et à qui il manque la lente initiation au travail scientifique et à l'utilisation des principales créations de la science, va se trouver du jour au lendemain en possession de tous les moyens que la technique moderne, industrielle ou autre, met à la disposition des hommes. Quel usage en fera-t-il ? Et à quelle conception de l'homme demandera-t-il la pensée directrice de son aménagement technique ? Deux exemples récents, nettement différents, mais également révélateurs, celui du Japon et celui de la Chine, donnent à cette question un commencement de réponse. Les nations occidentales, en tant que créatrices et détentrices des puissances techniques, ne peuvent pas ne pas avoir à l'égard du vaste problème que je viens d'indiquer de très lourdes responsabilités.

L'industrialisation concerne le Canada français au même titre que les autres, parce que lui aussi est issu d'une culture humaniste et chrétienne ; mais elle le concerne plus dangereusement parce qu'il est un peuple faible, encore en voie de formation et que les circonstances historiques l'ont placé dans le rayon d'influence immédiate de la plus grande puissance industrielle de tous les temps et l'ont forcé à participer à la vie commune d'un continent avant d'être en état de décider lui-même du moment, de la nature et de l'étendue de sa participation. Considéré du simple point de [p. 234] vue de la politique locale et des relations entre groupements ethniques distincts, il peut paraître indifférent, voire même désirable aux Américains et aux Anglo-Canadiens que le Canada français perde sa personnalité propre dans un complexe humain aux dimensions continentales. Un problème de moins! Mais considéré dans les perspectives que nous venons d'évoquer d'un monde rigoureusement tenu de repenser l'œuvre de ses mains, à moins d'être détruit par elle, il n'en est pas ainsi. Les antécédents du Canada français, ses traditions, son sens de l'homme, les tendances naturelles de son être et de son histoire sont un actif, non seulement pour lui-même, mais pour les populations avoisinantes, et doivent être conservés, sinon dans leur réalité concrète, du moins dans leur inspiration - car, dans la conjoncture actuelle du monde, la civilisation occidentale, humaniste et chrétienne, n'a pas les moyens de sacrifier même les moindres de ses forces.

Le régime social du Canada français, tel qu'édifié par les anciennes générations et tel qu'il subsiste encore dans certains centres de notre province, porte deux des caractéristiques de la civilisation particulière dont la nation elle-même procède.

D'abord il est personnaliste, c'est-à-dire ordonné à l'homme, à l'accomplissement de sa vocation. Il embrasse, en les situant chacune à son rang, l'ensemble des valeurs qui y concourent : économiques, intellectuelles, morales, religieuses. Et pour que ce personnalisme ne soit pas un vain mot, mais pour chacun une prérogative vécue, il lui donne comme fondement un régime de travail et un régime de propriété conçus de façon à assurer l'autonomie de l'homme sur le seul plan où initiative et responsabilités 
personnelles ont une signification et une valeur réelles : celui de la vie, privée, de l'activité quotidienne. Les libertés politiques dont on fait de nos jours si grand état n'ont elles-mêmes de sens que si elles procèdent de cette liberté initiale. D'une part, propriété terrienne, source de travail et de subsistance: c'est l'établissement agricole; d'autre part, métier et atelier: c'est l'établissement artisanal. Dans un cas comme dans l'autre, l'homme, maître de ses instruments de travail, a l'initiative de sa vie et en porte la responsabilité. En fait, on peut dire que cet ordre social est d'abord responsable, fondé sur la responsabilité personnelle de l'individu envers lui-même et envers ceux qui dépendent de lui ; et qu'il est libre parce que responsable.

[p. 235] En second lieu, il est communautaire, en ce sens qu'il conçoit l'insertion, selon un mode organique, de l'homme dans la société. Au premier palier, la famille et la profession. En réalisant l'association de la famille, du travail et de la propriété, l'établissement autonome, agricole ou artisanal, fournit l'unité de base de la société. Au second palier, pour remplir les fonctions dont la famille ne peut s'acquitter seule, la paroisse. La paroisse répond à des fins spécifiques d'ordre religieux, mais elle répond aussi à des fins sociales relevant en tout ou en partie du magistère de l'Église : assistance, enseignement. Elle a en outre, au cours de l'histoire, assumé, par carence de l'ancien régime seigneurial, des fonctions économico-sociales qui, bien que n'étant pas de la compétence propre de l'Église, ressortissent néanmoins à sa juridiction dans la mesure où elles touchent à la morale. Ainsi, dès le début de notre histoire, la paroisse s'est instituée en quelque sorte cellule initiale, communauté première de la vie nationale et, par elle, s'affirme au regard du monde le caractère foncièrement spiritualiste de notre civilisation d'origine.

Or, l'évolution politique et l'évolution sociale du Canada français ont suivi des trajectoires différents, voire même contradictoires. La première va dans le sens de l'autonomie pour aboutir au régime fédératif sous lequel nous vivons depuis 1867. Cet affranchissement a pu paraître une conquête définitive. Il n'en est rien. Car l'évolution sociale se produit, elle, dans le sens de l'intégration et tend à assimiler le Canada français au reste du pays et même du continent. De là le conflit entre une pensée politique toujours attachée à l'idée d'autonomie, et une pensée sociale disposée à accepter au moins certaines formes d'intégration.

Depuis la conquête britannique, notre histoire sociale peut être divisée à peu près en trois périodes : l'une qui va de 1763 à 1820 environ, et durant laquelle le régime économico-social de type paysan et artisanal édifié au temps de la Nouvelle-France continue de suffire à la fois à la subsistance de la population et à l'établissement de son accroissement naturel. Propriétaires de leurs instruments de travail, soustraits à toute dépendance commerciale extérieure, en état de diriger eux-mêmes leur vie communautaire, familiale, professionnelle et paroissiale, les Canadiens français, bien que soumis à une politique d'inspiration étrangère, sont cependant maîtres chez eux et peuvent continuer leur vie comme si rien [p. 236] d'important ne fût survenu dans leur histoire. Leur milieu réalise la grande condition de son efficacité nationale : il est homogène. 
La deuxième période s'étend de 1820 jusque vers 1880. Durant ces soixante années, le vieux régime économico-social suffit toujours à la subsistance de la population établie, mais faute d'une politique appropriée de colonisation et de mise en valeur rationnelle des ressources du sol, il ne pourvoit plus à l'établissement complet de l'accroissement naturel. C'est la période de l'émigration vers les États-Unis d'abord, puis vers les autres provinces. Le milieu national conserve son homogénéité, les Canadiens français restent maîtres chez eux, mais ils sont entravés dans leur expansion.

Enfin, la période d'urbanisation et d'industrialisation, l'une portant l'autre. Cette période commence en 1880 et peut être divisée en deux phases : celle du capitalisme libéral, close avec le début du siècle actuel, disons avec la guerre de 1914, phase pendant laquelle l'urbanisation s'effectue à une allure d'apparence normale et pendant laquelle les Canadiens français ont l'air de s'adapter sans trop de difficulté à la vie des villes. Puis, la phase du capitalisme de groupe qui dure toujours et pendant laquelle, par suite de la profonde et rapide transformation de l'économie de la province, se posent le problème économique et le problème social, tels que nous pouvons les observer de nos jours.

Dans les campagnes, lorsque, sous la poussée des pressions extérieures, l'économie paysanne a dû se transformer en économie commerciale, le coopératisme et l'association professionnelle, l'un et l'autre conformes par leur inspiration générale à nos traditions sociales, sont venus organiser la fonction sociale du travail, et ce passage de la simple solidarité familiale des périodes antérieures à la solidarité sociale des temps actuels s'est effectué dans les cadres et sous l'égide de la paroisse. Preuve que le vieux régime social conçu pour une économie de pionniers, donc nécessairement rurale possédait néanmoins assez de sève pour se dépasser lui-même, le moment venu, et s'adapter à des circonstances nouvelles.

Dans les villes, il n'en a pas été ainsi. Une économie d'inspiration libérale, donc conçue comme étant à elle-même sa propre loi et sa propre fin, une économie ordonnée au rendement et donc accordant aux techniques la priorité sur l'homme, s'y établissait. Au temps de l'entreprise individuelle et familiale, le désaccord entre la vieille [p. 237] tradition sociale et la pensée dont procédait l'économie nouvelle ne s'est pas révélé tout de suite dans toute son étendue, et c'est pourquoi durant sa première phase, l'urbanisation n'a pas paru devoir entraîner pour la société canadienne-française de trop graves conséquences, d'autant moins qu'elle se présentait comme remède au mal de l'émigration dont le Canada français était rongé depuis plus d'un demi-siècle. Mais le conflit éclate dans toute sa force avec l'avènement de la grande industrie. Les conséquences sont faciles à évaluer. Une population aux quatrecinquièmes rurale et aux neuf-dixièmes autonome est devenue aux trois-quarts urbaine et aux sept-dixièmes dépendante. Le problème social se présente donc aujourd'hui dans des perspectives complètement différentes.

Quelle attitude prendre à son égard ? Non pas évidemment celle du refus. L'industrie est la vocation de notre sol, une nécessité de notre époque, un besoin de notre population. Et d'ailleurs elle est là ! La seule attitude logique et féconde est celle qui continue de tendre vers l'avenir en retenant du passé ce 
qui est véritablement exigé par le progrès humain et par la civilisation au sens propre du mot. Or, ce qui, dans notre histoire, a pleine valeur humanisante et civilisatrice, ce ne sont pas les modalités institutionnelles d'un ordre social et politique conçu pour une époque et un milieu différents. Les modalités, fussent-elles juridiques ou sociales, sont comme le vêtement : elles s'usent et doivent périodiquement être renouvelées et, selon les besoins repensées. Ce qui dans notre passé social doit être retenu, c'est l'esprit dont procédaient les institutions, les modes de vie. Le personnalisme et le sens communautaire évoqués il y a un instant, issus d'une conception spiritualiste de l'homme, sont des valeurs permanentes et universelles qui ont autant de prix pour les populations qui nous entourent qu'elles en ont pour nous-mêmes. Ce sont ces valeurs-là : sens de l'homme et de sa vocation spirituelle, sens de la liberté et de la responsabilité, sens communautaire, familial et professionnel, s'épanouissant dans un véritable sens de la solidarité et de la fraternité sociales, sens de la continuité, sens de la qualité, - ce sont ces valeurs-là, substance même de notre civilisation d'origine, dont il faut faire reprendre conscience à notre population, afin qu'elle aime en vivre et que, spontanément, du seul fait qu'elle en vit, elle les exprime dans des œuvres originales et les intègre dans un régime institutionnel économique, social et politique qui, adapté à notre époque, [p. 238] n'en reflétera pas moins intensément les véritables richesses de notre histoire.

C'est ce que j'appelais il y a un instant voir les faits par le dedans : faits de l'histoire, faits du moment présent, qui, nous le savons bien, préparent les faits des années à venir. Telle est notre tâche, à nous qui sommes déjà engagés dans la carrière; à nous surtout à qui incombe la responsabilité de préparer des jeunes aux carrières d'économistes, de sociologues, d'observateurs et de guides de la vie sociale. Dans la conjoncture actuelle de la société et du monde, c'est une tâche très lourde, mais dont la grandeur est aux dimensions mêmes de ses exigences. 
[p. 239]

\title{
CHAPITRE XII
}

\author{
PERSPECTIVES
}

\section{Jean-Charles Falardeau}

$\underline{\text { Retour à la table des matières }}$

Toute étude sur le Québec, comme le rappelle M. O.-J. Firestone, est une étude de contrastes. Les chapitres de ce volume le prouvent à l'évidence. En outre des contrastes dans les faits eux-mêmes, nous y trouvons des jugements divergents, antithétiques, quelquefois contradictoires. De toutes ces mélodies discordantes, quelle symphonie tirer?

Certaines études de ce volume risquent, si l'on n'y prend garde, d'accréditer deux fausses idées claires touchant l'évolution du Québec. La première de ces notions est que l'industrialisation fut un phénomène soudain. La seconde est que cette industrialisation s'est imposée aux Canadiens français et en quelque sorte accomplie malgré eux. Ces deux notions contiennent chacune une part de vérité mais elles demandent l'une et l'autre à être précisées, sans quoi on peut succomber à la facile tentation de considérer l'industrialisation comme un mythe qui deviendra lui-même un objet de fixation des ressentiments canadiens-français.

Des remarques de l'économiste Herbert Frankel peuvent aider à mettre au point notre jugement sur l'aventure québécoise. On est en général trop porté, écrivait-il récemment ${ }^{1}$, à parler des " conséquences sociales des changements technologiques ». Nous présumons invariablement que, d'une part, il y a une cause, l'industrie, et d'autre part, un état social qui en est la conséquence. « Nous avons pris l'habitude de considérer les changements technologiques ... comme une force indépendante qui, en agissant sur la société, déclenche

De quelques manières de concevoir l'«évolution technique », Bulletin international des Sciences sociales, vol. IV, $\mathrm{n}^{\circ} 2$, été 1952, pp. 272-279. Le passage cité est directement traduit de l'édition anglaise. 
certaines réactions ». Or, ce faisant, nous méconnaissons que les changements technologiques eux-mêmes sont une conséquence sociale. L'introduction dans une société de [p. 240] nouveautés techniques ou d'industries nouvelles présuppose des modifications fondamentales dans les structures juridiques, économiques et politiques de cette société. L'état social doit rendre possible, à un moment donné, l'implantation de l'industrialisme. Le degré de disponibilité de l'état social peut varier mais celui-ci doit, jusqu'à un certain point, coopérer avec le changement. Changements technologiques et états sociaux sont intimement, conjugués et c'est cette conjugaison continue qui constitue le processus de l'évolution sociale.

Si l'on y regarde de près, l'évolution québécoise ne fut, en définitive, rien d'autre que l'expérience à l'échelle régionale d'une immense évolution économique qu'ont dû subir, à diverses périodes de l'histoire, toutes les régions nord-américaines. Bien que nous soyons naturellement portés à prêter surtout attention aux brusques transformations des années 1920 et des quinze dernières années, ces sursauts ne doivent pas nous faire perdre de vue que l'industrialisation du Québec fut dans l'ensemble un phénomène graduel.

La Confédération canadienne, créée dans une très large mesure pour des raisons d'ordre économique, rendit notre province irrévocablement solidaire d'une économie nationale dont l'histoire fut un constant jeu et contre-jeu d'équilibre entre les unités géographiques et politiques qui la constituent. L'aventure économique du Québec est inséparable de celle de l'Ontario. Bien plus, le voisinage des États-Unis, sans lequel l'histoire du Canada français ne peut non plus se comprendre, devait tôt ou tard faire de notre territoire à la fois un milieu d'expansion pour la technologie américaine et un marché pour sa production.

L'étude de MM. Faucher et Lamontagne rappelle quelle importance il faut respectivement accorder aux facteurs géographiques locaux et continentaux, à l'évolution de la technologie et aux politiques douanières pour rendre compte du développement industriel québécois depuis un siècle. Nous avons connu des commencements industriels successifs. Entre certains d'entre eux, il y eut des hiatus. Quelques-uns se sont accrochés en se superposant les uns aux autres. Ce fut l'essor de la construction maritime au milieu du $\mathrm{XIX}^{\mathrm{e}}$ siècle, suivi d'un moment de répit. Le tournant du $\mathrm{XX}^{\mathrm{e}}$ siècle fut l'époque de l'industrie du cuir, de l'exploitation de l'amiante et des ressources forestières, de la fabrication du tabac et des textiles. Depuis les alentours de 1920 sont survenues les [p. 241] industries associées aux découvertes minéralogiques ou au harnachement de l'énergie hydro-électrique: fabrication de la pâte, du papier et de l'aluminium, exploitation des gisements miniers du bouclier laurentien, industrie chimique et sidérurgique, fabrication des appareils électriques. Au cours de cette ascension par bonds et par sauts, deux phases capitales sont à distinguer : la longue période (1866-1911) qui comprend les premiers développements correspondant à la fin de l'ère commerciale et une stagnation relative au moment du nouvel industrialisme ; la phase d'intégration complète de l'économie québécoise à l'économie continentale, au cours de laquelle nous avons assisté à des élargissements synchroniques de tous les éléments de l'éventail industriel. 
Chaque époque, ou mieux, chaque famille industrielle a embrigadé son contingent de travailleurs. Dans chaque contingent il y avait, en proportion variable selon les époques, de nouveaux venus qui étaient artisans ou fils de cultivateurs de la campagne, et d'anciens ouvriers qui avaient déjà l'expérience d'un métier pratiqué en divers milieux. La mobilité professionnelle des Canadiens français dont parle le chapitre $\mathrm{V}$ n'a fait très souvent que refléter le passage des travailleurs d'une industrie à une autre lorsque la première périclitait, ou relâchait sensiblement ses activités, ou se transportait d'un lieu à un autre. Mon grand-père maternel, né à Saint-Raymond de Portneuf en 1846, débuta comme menuisier à l'atelier de fabrication de wagons de la Cie Québec et Lac Saint-Jean localisé dans son village, alors un important centre d'activités ferroviaires. Le transfert de cet atelier à Québec vers 1888 le laissa sans emploi. Attiré par les sollicitations d'un cousin émigré aux États-Unis, il déplaça sa jeune famille et s'en fut gagner sa vie, durant cinq ans, comme charpentier, aux mines de cuivre du nord de l'état du Michigan. Revenu à Québec en 1893, il travailla comme charpentier-menuisier, d'abord aux ateliers du Grand-Nord, ensuite à l'emploi de divers entrepreneurs, jusque vers 1920 . Durant ses dernières années jusqu'à sa mort en 1926, il fut gardien de nuit dans une grande maison de commerce dont le succès était intimement lié à l'essor industriel d'après-guerre. Il faudrait étudier en détail l'histoire d'un grand nombre d'occupations pour savoir ce que fut, de génération en génération, la montée progressive ou la régression de diverses couches de population dans le nouveau régime de division du travail social. L'histoire des bûcherons serait, par [p. 242] exemple, à ce sujet très révélatrice en ce qu'elle nous ferait voir jusqu'à quel point cette occupation saisonnière est demeurée complémentaire de l'exploitation rurale, et jusqu'à quel point, inversement, elle a constitué un moyen d'acheminement définitif des ruraux vers la vie industrielle.

L'apparente soudaineté de l'industrialisation québécoise tient à ce que certaines de ses conséquences nous sont apparues massivement, il y a à peine vingt ans. Or, déjà à ce moment, le sursaut industriel postérieur à la première grande guerre datait de quinze ans. Il avait mobilisé, comme à notre insu, un plus grand nombre d'ouvriers que jamais auparavant. Mais survint la dépression des années 1930. Le nombre des sans-travail accumulés dans les villes, la nouveauté des problèmes économiques qu'ils posaient et la variété des revendications sociales qu'ils exprimaient nous firent prendre conscience pour la première fois de l'existence des masses urbaines. Indirectement, nous découvrîmes l'ampleur qu'avait prise la vie industrielle dans notre milieu. Ce fut l'heure d'un grand désenchantement, longtemps après le fait accompli.

La deuxième question qui se pose est d'élucider jusqu'à quel point l'état social du Québec était prédisposé à l'industrie. Il importe à ce sujet de distinguer entre les deux phases de notre industrialisation. Durant la première phase, tout au moins à ses débuts, il y eut coïncidence relative entre les exigences technologiques et la tradition artisanale québécoise. Un grand nombre de Canadiens français participèrent comme spécialistes à plusieurs entreprises d'une province qui se trouva à ce moment à l'avant-garde du progrès et des innovations. Rappelons que le premier transocéanique à vapeur, le Royal-Williams, fut construit à Québec. Le canal de Lachine, sans compter les canaux construits par les trafiquants de fourrure à la fin du XVIII ${ }^{\mathrm{e}}$ siècle 
sur la rivière Ottawa, fut parmi les premiers canaux canadiens. Les premières forges au charbon de bois furent celles de Trois-Rivières et de Batiscan.

La seconde phase présente un tableau fort différent. À l'époque contemporaine, la technologie nord-américaine a constitué une «force indépendante " de la société canadienne-française. Elle a envahi le Québec sous la pression de facteurs que l'étude de MM. Faucher et Lamontagne met en évidence. Toutes les études du symposium établissent aussi que les Canadiens français n'ont, en aucune manière, participé à l'application de cette technologie. Les [p. 243] innovations techniques furent littéralement implantées chez nous par des ingénieurs anglophones. Les institutions nécessaires à la formation des techniciens de type moderne n'existaient pas ici et l'exposé de M. Léon Lortie atteste que nos efforts d'adaptation en sont restés durant longtemps au plan élémentaire. Nous nous sommes contentés d'écoles techniques, c'est-à-dire d'institutions où l'on devait tenter de transformer rapidement les héritiers d'une tradition artisanale en ouvriers du $\mathrm{XX}^{\mathrm{e}}$ siècle. Ce n'est que tardivement, vers 1920, que l'on entreprit de former des candidats qui fussent aptes à coopérer à l'effort technologique sur le plan de l'imagination créatrice. Je sais qu'il y eut aussi, très tôt, l'École Polytechnique de Montréal, mais il reste à déterminer si le sens de son orientation initiale réelle contredit substantiellement nos affirmations.

Quant au rôle qu'ont pu jouer nos institutions financières dans la mise-enbranle des industries, les faits connus ne permettent aucune affirmation générale. On ne connaît pas assez l'histoire d'établissements bancaires tels que la Caisse d'Économie de Notre-Dame-de-Québec et la Caisse d'Économie du District de Montréal, de la Banque Nationale, et de leurs grands directeurs. Ce que l'on sait des Caisses populaires Desjardins ${ }^{1}$ est qu'elles ont surtout prêché l'épargne et peu incité aux initiatives nouvelles. Elles ont maintenu à un minimum la propension à investir, accréditant ainsi l'idée que les Canadiens français sont destinés aux « petites affaires ${ }^{2}$.

À la vérité, déjà il y a plus d'un siècle, Étienne Parent exhortait ses compatriotes à jouer un rôle actif dans la vie économique du pays. Joseph Bouchette et Errol Bouchette répétèrent plus tard l'injonction avec un accent d'alarme et d'angoisse. Plus près de nous, ce fut le labeur méritoire de toute la vie d'un Montpetit de prouver aux Canadiens français que l'activité ou le risque économique ne comportent aucun stigmate ${ }^{3}$. Ces objurgations fouettèrent la curiosité sans animer d'entreprises audacieuses. Jusqu'à une époque très récente, les Canadiens français se sont plutôt révélés d'habiles dirigeants d'entreprises commerciales [p. 244] que de grands capitaines d'industrie. La fin du XIX ${ }^{\mathrm{e}}$ siècle vit une remarquable efflorescence, tant à Québec qu'à Montréal, de maisons de commerce canadiennes-françaises qui furent fondées modestement et devinrent en moins d'une génération de grands et prospères établissements. Mais les remarques de M. Minville et de M.

Cyrille VAILLANCOURT et Albert FAUCHER, Alphonse Desjardins, pionnier de la Coopération d'épargne et de crédit en Amérique, Éditions Le Quotidien, Lévis, 1950.

2 Esdras MINVILLE, Economic and social tendencies of French Canada, University of Toronto Quarterly, vol. XIX, No. 2, January 1950, pp. 141-157.

Ibid., p. 145. 
Hughes soulignent le décalage considérable entre la grande société financière, anonyme et complexe, qui domine l'industrie moderne, et le type d'entreprise à caractère personnel ou familial qui correspondait à nos habitudes économiques. Les techniques de l'industrie moderne exigent d'immenses mises de capitaux. La production industrielle, pour être rentable, doit se pratiquer sur une très grande échelle. Il était presque inévitable que le capital nécessaire à l'industrie nous vînt des États-Unis.

Pour toutes ces raisons et d'autres que l'histoire établira, certains éléments de l'état social du Québec ou bien se sont aisément prêtés, ou bien se sont spontanément associés à l'importation des industries de la deuxième phase. En premier lieu, la mobilité artisanale que l'on vient d'évoquer était, de sa nature, utilisable par le nouvel industrialisme capitaliste Sans tradition syndicale, sans organisation ouvrière encore bien définie, l'artisan canadien-français rural ou urbain était une recrue toute désignée pour l'usine et la filature. Évoquons en outre encore une fois le truisme que le régime familial canadien-français, exigeant à chaque génération le départ de tous les enfants non-héritiers, postulait un débouché constant pour ce trop-plein de population. Les régions nouvelles à coloniser, les villes de la Nouvelle-Angleterre et du Centre américain, l'Ouest canadien, ont successivement rempli cette fonction de déversoir. L'histoire de ce perpétuel mouvement démographique nous est familière, en particulier celle du regrettable exode vers les États-Unis où l'on estime qu'environ 400,000 Canadiens français ont émigré entre 1871 et $1931{ }^{1}$. À chacune de ces époques, l'établissement d'industries nouvelles est venu faciliter l'absorption sur place d'une partie de cette population migratrice par nécessité. Depuis la première grande guerre, compte tenu des nouveaux colons qui se dirigèrent vers la Gaspésie et l'Abitibi, les filatures et les usines devinrent les seuls débouchés disponibles.

\section{[p. 245]}

L'accord social avec l'industrie fut explicite sur le plan politique. Le pouvoir politique québécois, par son action législative, par des gestes financiers et par des mesures juridiques de toutes sortes a attiré dans notre milieu les entreprises industrielles étrangères. Non seulement il a accueilli ces partenaires tout-puissants de notre vie économique mais il les a invités à la danse, en leur offrant souvent le bâton de chef d'orchestre. Il y a toute une tradition québécoise, depuis Chapleau et Mercier, d'hospitalité joyeuse envers le capital et les magnats américains. Qu'il suffise d'évoquer la politique de concessions à perpétuité d'immenses portions du domaine public aux compagnies américaines fabricantes de pâte et de papier, établie par le gouvernement Gouin et poursuivie par tous les gouvernements subséquents; les dégrèvements d'impôts accordés aux entreprises minières et hydroélectriques; les ententes officieuses ou occultes aux termes desquelles de puissants intérêts étrangers se sont vu octroyer des privilèges étonnants. Sans oublier les cas innombrables où, nonobstant les textes officiels de la législation

Voir, Georges LANGLOIS, Histoire de la population canadienne-française, éditions Albert Lévesque, $2^{\mathrm{e}}$ édition, Montréal, 1935, Première partie, Livre III, ch. IV, pp. 171184. 
du travail, le pouvoir politique s'est allègrement constitué l'allié des employeurs étrangers dès qu'il s'agissait de reconnaissance ou de revendication syndicales. Le P. Cousineau et M. Jacques Perrault précisent en quel sens la formule des «syndicats de compagnie » fut invariablement l'expression et l'instrument d'une politique conjointe de paternalisme d'allure libérale mais foncièrement anti-syndicale. En fait, cette alliance intime entre le pouvoir politique québécois et les patrons lointains, généralement anonymes, des entreprises industrielles, est une caractéristique marquante d'une longue période historique - dont on peut se demander encore si elle est réellement terminée.

Seule une étude approfondie, encore à venir, de ces aspects de notre histoire économique et politique nous permettrait d'apprécier combien les Canadiens français ont coopéré à ce qu'on a appelé l'invasion de leur société par l'industrie. Je dis bien les Canadiens français, car on pourrait alléguer que seuls les gouvernements québécois, un peu à la manière d'une cinquième colonne, ont sollicité l'invasion tandis que la masse de la population, au contraire, l'a subie. Or, tel n'est pas tout à fait le cas. Notre société a consenti à l'industrialisation ainsi qu'à la façon dont celle-ci s'est accomplie, y compris les condescendances politiques qui l'ont rendue possible et qui l'ont accélérée. Il est vrai qu'en général une société est [p. 246] volontiers passive devant les faits politiques accomplis, surtout dans le domaine économique. Mais la politique des gouvernements québécois n'aurait pu se perpétuer durant un demi-siècle, quel que fût le parti au pouvoir, si elle n'eût été supportée par un climat social approbateur sinon par l'appui favorable d'une très grande variété de groupes. Ce consentement eut des motivations et prit des formes diverses selon les couches de la population. Pour les travailleurs, qu'ils fussent d'extraction rurale ou urbaine, l'industrie a signifié un gagne-pain. Les classes moyennes et bourgeoises y ont vu, à cause de l'expansion du commerce et des établissements de service qu'elle provoquait, un facteur croissant de prospérité. Ce n'est qu'au moment et à la suite de la dépression de 1930 que les individus et les groupes économiquement vulnérables se mirent à condamner les propriétaires d'industrie. Ce qui était une réaction contre le capitalisme en tant que système économico-social devint une réaction contre les représentants locaux du système. Sous plusieurs rapports, nous réagîmes à la dépression selon les mêmes tangentes que le Canada de langue anglaise. Dans l'ensemble du pays, on assista à une vive recrudescence du sentiment anticapitaliste, incarné dans le parti CCF, et de l'antisémitisme, propagé par le Crédit social. Semblablement, ce fut dans notre province l'époque des mouvements de reconstruction sociale, de divers fascismes antisémites et des premiers succès du Crédit social. Dans les deux cas, il y eut à la fois identification de certaines causes réelles et, par une série de transferts psychologiques ${ }^{1}$, de causes présumées des déboires économiques. Mais, à cette collection de responsables, la province de Québec ajouta un bouc émissaire particulier : les " Anglais ». Cette déviation du sens de la dépression et cette définition mythique de la cause de nos problèmes furent le résultat des propos nationalistes.

Everett-C. HUGUES, French Canada in transition ou Rencontre de deux mondes, ch. XIX. 
Comme le note M. Mason Wade, aux environs de 1920, la pensée de quelques théoriciens du nationalisme avait pris une orientation économique. Aux anciens thèmes réalistes de Bouchette, on ajoutait des variations martiales. Le sentiment anglophobe avait atteint un paroxysme durant la première guerre : on le transposa en un sentiment d'hostilité contre «les exploitants étrangers de nos ressources naturelles ». Nous n'étions plus maîtres de notre éco-[p. 247] nomie. Nous avions laissé dilapider notre patrimoine en demeurant, selon l'aphorisme complaisamment répété à l'époque, «des porteurs d'eau et des scieurs de bois ». Nous étions dans le marasme à cause des Anglais. On fit un inventaire de la participation des Canadiens français à la vie économique de Montréal et de la province. M. Victor Barbeau, avec une délectation morose, prit, en 1936, " la mesure de notre taille ». On lança des campagnes d'achat chez-nous et on prêcha la reconquête "des leviers de commande ». Ces formules d'insatisfaction s'incrustèrent dans la conscience publique. Associées plus tard à un sentiment grandissant de mécontentement envers une administration libérale depuis longtemps au pouvoir et jugée décadente, elles expliquent l'état d'esprit qui provoqua un changement de gouvernement en 1936.

Il est peut-être nécessaire, à ce point, de circonscrire ce qu'on doit entendre, à notre époque, par le " nationalisme » canadien-français. C'est là un terme ambigu autant que la réalité qu'il désigne est fluide. M. Lorenzo Paré a raison, en un sens, d'affirmer que ce qu'on appelle le « nationalisme » chez une minorité comme le Canada français «n'est que l'expression normale de la conscience politique ». Comme notre conscience, après la conquête anglaise, fut mise à vif, l'expression politique de notre patriotisme dut prendre une allure combattive et agressive. Nous n'avons pas à refaire ici l'histoire admirable de la reconquête de nos institutions et de la reconnaissance de notre culture au cours du $\mathrm{XIX}^{\mathrm{e}}$ siècle. Mais à ces revendications nécessaires s'est historiquement ajouté un credo politique dont les disciples d'Henri Bourassa ont défini les articles de foi. C'est à ce credo exagérément ethnocentrique, dogmatique et emmêlé de notions religieuses, que s'applique l'étiquette de nationalisme. Son contenu précis a varié avec les époques comme a varié l'exploitation qu'en ont faite les hommes politiques ${ }^{1}$. Il est quelquefois périlleusement associé à certaines de nos attitudes proprement religieuses et se retrouve facilement dans la bouche de quiconque cherche à séduire un groupe ou l'autre de notre population.

Le nationalisme en tant que credo n'a jamais été accepté de façon totale, à quelque époque que ce soit, que par un nombre relativement restreint d'individus ou de cénacles. Souvent même ceux-ci [p. 248] n'y ont adhéré que pour un temps. La majorité de la société canadienne-française n'y a prêté un intérêt politique réel que de façon épisodique, à des moments de crise. C'est peut-être ce qui explique, comme le rappelle encore M. Paré « qu'aucun parti nationaliste n'ait jamais réussi à survivre chez les Canadiens français ». L'opinion collective à la façon d'une rivière méandreuse, épouse sans effort les rives indiquées par des intérêts plus immédiats. Les alluvions du nationalisme

Voir, André LAURENDEAU, Y a-t-il une crise du nationalisme ? L'Action nationale, vol. XL, n 3, décembre 1952, vol. XLI, n 1, janvier 1953. 
font cependant partie du terrain où elle s'avance : à la moindre bourrasque, le vent en ramène l'argile à la surface et elle colore pour un temps, plus ou moins violemment, cette eau capricieuse. Ainsi, au moment de la dépression de 1930, la reconquête des entreprises économiques par les Canadiens français fut collectivement considérée, par suite de l'argumentation nationaliste depuis dix ans, comme une reconquête de «nos droits ». Le raisonnement un peu hâtif de cette argumentation sous-entendait que les financiers américains ou les gérants britanniques des industries québécoises étaient les descendants directs et les héritiers des capitaines de l'armée de Wolfe ou de la « clique du Château ». On les rendait personnellement responsables de la dépression. On télescopait l'histoire et on mobilisait, pour une croisade aux objectifs mal définis, un arsenal toujours disponible de généreux sentiments patriotiques.

Le refus de l'industrialisation par la pensée nationaliste nous fait toucher l'un des caractères essentiels de notre société, à savoir, le décalage souvent considérable entre l'image "officielle » du Canada français qui est proposée par certains interprètes de la société et, d'autre part, les situations de fait et les sentiments réels de la population. Ces interprètes se sont surtout retrouvés sur le plan politique et sur le plan religieux. Très souvent leurs interprétations étaient à l'origine fort éloignées du sentiment général d'indifférence ou d'acceptation mais elles ont eu, avec le temps, une influence profonde sur ce même sentiment collectif. Notre société n'a pas échappé à la règle universelle et elle a graduellement accepté la «définition de sa situation » que lui proposaient plusieurs de ses chefs reconnus ou improvisés. Or, quand les hommes considèrent des situations comme réelles, selon l'axiome classique de W. I. Thomas, ces situations sont réelles dans leurs conséquences. C'est-à-dire que «les hommes, comme le précise Robert K. Merton, réagissent non seulement aux caractères objec-[p. 249] tifs d'une situation, mais aussi, et parfois surtout, à la signification qu'ils donnent à cette situation. Cette signification, une fois donnée, détermine le comportement qui en résulte avec ses conséquences ${ }^{1}{ }^{1}$. Plusieurs classes de la société canadienne-française ayant accepté la signification de leur situation dictée par des interprètes en qui elles avaient confiance réagirent dorénavant de façon hostile contre les agents de l'industrialisation.

Les premiers de ces interprètes, nous venons de le noter, ont été les chefs nationalistes dont la rhétorique a élaboré l'image d'un Canada français aigri et révolté contre " les autres ». L'image idéalisée de nous-mêmes que le clergé a très longtemps offert à notre méditation est analysée par $\mathrm{M}$. Maurice Tremblay. Elle était transfigurée, comme il le rappelle, par la nostalgie d'un âge d'or du Canada français rural et paroissial et par un souci de fidélité à une philosophie de frugalité économique et de soumission à toute autorité établie. Cette image dont $\mathrm{M}^{\text {gr }}$ Pâquet a consacré l'auréole dans son célèbre discours de juin 1902 impliquait à la fois une interprétation lyrique de la réalité historique et le sentiment d'une mission à poursuivre. Elle combinait un jugement de fait avec une injonction. C'est elle qui, jusqu'à une époque récente, a inspiré l'action sociale du clergé dans notre province. Elle a empêché celui-ci, par

Robert K. MERTON, Éléments de méthode sociologique, Paris, Librairie Plon, 1953, traduction Henri Mendras, ch. IV, p. 170. 
exemple, de reconnaître les vraies causes du dépeuplement rural comme elle lui a fait accorder une importance de premier rang aux mouvements de colonisation tandis que se constituait à son insu un prolétariat urbain. Justement, l'attitude du clergé durant la longue phase des débuts du syndicalisme catholique a été, en général, de traiter les ouvriers comme s'ils eussent été seulement une nouvelle catégorie de paroissiens. L'usine était un mal nécessaire mais suspect parce qu'elle empêchait la pratique des vertus traditionnelles ; être ouvrier constituait une déchéance qu'il fallait en quelque sorte racheter par une acceptation résignée des dures conditions de travail imposées par les patrons, quels qu'ils fussent.

Le contraste entre les façons de penser des années 1930 et celles d'aujourd'hui est, en ce domaine aussi, très frappant. Depuis quelques années, en particulier depuis la Lettre pastorale collective sur le problème ouvrier de 1949, les chefs ecclésiastiques eux-mêmes reconnaissent combien cette conception du Canada français [p. 250] s'était éloignée de la réalité. En outre, par la force des choses, le clergé séculier et régulier s'est recruté de plus en plus dans les milieux ouvriers. Ces prêtres ont connu d'expérience personnelle, dans leur famille, les conditions de la vie ouvrière et urbaine ; ils en savent les difficultés et les grandeurs. Le sens plus réaliste de leur apostolat n'est pas l'un des moindres facteurs qui expliquent l'ampleur récente qu'a prise le syndicalisme catholique.

Tous les facteurs individuels et sociaux qui ont entraîné la rénovation contemporaine de ce syndicalisme catholique dans notre province ne pourront être dégagés que par les sociologues de l'avenir. Cette rénovation, œuvre de jeunes chefs clairvoyants secondés par de généreux conseillers ecclésiastiques, constitue très probablement le plus remarquable phénomène de dynamisme réaliste qui se soit produit dans notre société à notre époque. La qualité de ce phénomène imprévisible tient à une conjoncture d'heureux événements, inédite dans notre histoire : le réalisme avec lequel on a diagnostiqué, sous tous ses aspects, la situation des ouvriers dans notre milieu ; l'intrépidité avec laquelle on a rejoint le sens profond de la philosophie sociale de l'Église que des intérêts établis avaient trop souvent édulcorée ; la franchise avec laquelle on a posé les conditions du bien-être économique et moral des ouvriers ; la largeur de vue avec laquelle on a proposé la coopération avec les autres mouvements syndicaux et entrepris l'éducation du sens de la responsabilité sociale chez les travailleurs.

Le syndicalisme a peut-être contribué à cristalliser davantage une conscience de classe qui existait de façon diffuse chez les ouvriers québécois. Ce qui n'a pu se produire en 1930 à cause de l'état d'esprit nationaliste s'est ostensiblement manifesté depuis la deuxième guerre mondiale. Les attitudes qu'on a prises au sujet du syndicalisme, les réactions publiques qui se sont exprimées à l'occasion des deux grèves retentissantes d'Asbestos en 1949 et de Louiseville en 1952 et de la grève au magasin Dupuis de Montréal en 1952 ont sûrement révélé avec plus de netteté que jamais le clivage qui sépare les ouvriers du reste de la population. Le fait significatif est que les ruraux et les «collets blancs» de toutes catégories se dissocient maintenant du monde ouvrier. Deux univers sociaux se sont créés qui ne parlent plus le même 
langage et qui n'ont de dénominateur commun que ce qui les oppose ethniquement et religieusement au monde extérieur.

[p. 251]

Une prise de conscience de plus en plus vive des différences d'intérêts économiques entre les classes contribue, semble-t-il, à atténuer dorénavant les différences ethniques et religieuses entre les Canadiens français et le reste du pays. De plus en plus, les réactions sociales de notre milieu sont des réactions de classes. Notons seulement, comme expression de cette tendance, le ralliement du syndicalisme catholique et des fédérations syndicales nationales, la collaboration entre la Fédération des Chambres de commerce québécoises et les Chambres canadiennes ainsi que l'engagement de plus en plus actif des Canadiens français de divers groupes commerciaux et professionnels dans les associations nationales ou américaines.

De fait, le processus fondamental de notre société dont traitent directement ou indirectement les études de ce volume et dont l'industrialisation ne fut en définitive qu'une des manifestations est celui de l'américanisation. Pas plus que le Canada tout entier, nous ne pouvions échapper à la pénétration multiforme de notre milieu par les institutions et les modes de vie et de pensée de la civilisation américaine. Le bilan général de l'étendue de l'influence américaine dans les domaines politique, économique et social, établi par M. Gustave Lanctôt en 1941, conserve toute son actualité ${ }^{1}$. M. Lanctôt observait que cette américanisation se révélait plutôt dans l'existence matérielle que dans la vie morale mais que «le Québécois, matériellement américanisé, n'a guère de réadaptation à faire pour s'américaniser de maintes façons socialement et moralement $"{ }^{2}$. M. Minville, à la suite de M. Montpetit ${ }^{3}$, note avec une juste perplexité quels dangers accrus la promiscuité du géant du sud comporte pour la culture canadienne-française. Je sais qu'il est facile d'énumérer les méfaits du magazine, d'une certaine littérature du dimanche, de la radio et du cinéma américains. Ces produits élémentaires et fréquemment toxiques ne peuvent être considérés comme l'expression de la totalité de la civilisation américaine. Il n'en reste pas moins que ces virus filtrants ont infiniment plus métamorphosé mentalement la masse de [p. 252] notre population que n'ont eu d'influence sur notre "élite» la pensée d'un John Dewey, la revue Commonwealth ou Partisan Review. Nos façons de construire une maison, de manger, de nous récréer, toutes nos habitudes de vie quotidienne ainsi que beaucoup de nos formes d'ambition professionnelle ou sociale sont devenues les mêmes que celles du reste du continent.

Inutile d'énumérer les agents de cette américanisation qui ont inclus, bien avant les touristes saisonniers, les agents d'assurance et les techniciens de l'industrie, nos propres grands-parents ou leurs cousins qui émigrèrent en Nouvelle-Angleterre et ré-importèrent dans notre campagne et nos villages le

Le Québec et les États-Unis, 1867-1937, dans Les Canadiens français et leurs voisins du sud, publié sous la direction de Gustave Lanctôt, Montréal, Éditions Bernard Valiquette, 1941, ch. VII, pp. 269-310.

Ibid., pp. 304, 309.

Reflets d'Amérique, Montréal, Éditions Bernard Valiquette, 1941. 
mirage des «villes des États». Tout bien considéré, la notion d'américanisation n'est pas loin de désigner les mêmes réalités que sous-entend le concept d'urbanisation. Les causes et les modes du développement urbain en notre province furent américains par nature. La métropole montréalaise en représente la synthèse finale en même temps que le prototype et le lieu constant d'inspiration. On ne se rend peut-être pas assez compte du fait que la conurbation métropolitaine de Montréal contient environ la moitié de la population de la province. Devenue le lieu de convergence du réseau routier qui la relie de façon de plus en plus rapide avec toutes les régions de la province, elle est aussi, par le commerce, la radio et la concentration des activités sportives et culturelles, le centre de diffusion de la civilisation urbaine dans notre milieu ${ }^{1}$. Elle est, par vocation inéluctable, le lieu où les problèmes se posent d'abord, où se concrétisent les modèles nouveaux d'action et de pensée, où se produisent les chocs sociaux importants, où s'élaborent les institutions nouvelles et où s'accentue la sécularisation de la pensée canadienne-française.

C'est contre certaines formes de cette civilisation urbaine et américaine fondamentalement antinomiques avec sa philosophie de la vie et sa philosophie tout court, que le Canada français oppose opiniâtrement l'affirmation de son identité religieuse et culturelle. Là réside le vrai drame de notre société plutôt que sur le plan des relations avec nos compatriotes de langue anglaise ou de nos relations constitutionnelles avec le gouvernement fédéral. Or, les [p. 253] observateurs de ce drame ne parviennent pas à être optimistes $^{2}$. D'une part, le nombre de ceux qui résistent consciemment à l'américanisation du langage et de la pensée augmente constamment : on les retrouve dans l'enseignement universitaire et secondaire, dans les beaux-arts et les lettres, à la radio, dans le journalisme. Ils constituent une avant-garde de plus en plus lucide et résolue à purifier notre culture par une osmose plus intense avec la civilisation française. Mais il semble qu'au fur et, à mesure que cette avant-garde croît en nombre et en sagesse, l'écart s'élargit entre elle et la masse de la population. On croit voir s'ouvrir une paire de ciseaux.

C'est à ce carrefour de la lutte pour la préservation de la culture que se situe la douloureuse responsabilité des institutions d'enseignement du Québec, aux plans universitaire, secondaire et primaire. Les réflexions de M. Arthur Tremblay reflètent le souci crucial des éducateurs et l'état radicalement insatisfaisant de notre système d'enseignement. Le collège classique, dont $\mathrm{M}$. Maurice Tremblay a montré qu'il était au centre de notre structure sociale, en est rendu à une croisée qui l'oblige à réviser la modalité de ses fonctions éducatrices et sociales et à reconnaître toutes les exigences de son caractère à la fois secondaire et universitaire. D'autres institutions d'enseignement secondaire ont proliféré. Tous leurs élèves ne peuvent encore accéder directement à l'université, bien que ce soit parmi eux que se trouve la plus forte proportion des candidats aux carrières nouvelles du commerce et de

Guy ROCHER, Industrialisation et culture urbaine, dans Contributions à l'Étude des sciences de l'homme, Montréal, 1952, $\mathrm{n}^{\circ}$ 1, p. 167.

2 Voir, Roch VALIN, Quelques aspects linguistiques de l'enseignement du français, Nouvelle Revue Canadienne, vol. 11, n 6, juin-juillet 1953, pp. 333-341. 
l'industrie. Le cul-de-sac de l'enseignement primaire a été battu en brèche : il reste à le faire déboucher sur le palier pré-universitaire tout en préservant ce qu'il y a d'authentique dans notre tradition humaniste. À quoi M. Hughes ajoute que les universités du Québec seraient sages, avant d'importer directement des programmes d'enseignement, «adaptés » aux exigences de la vie industrielle, de « vérifier si ceux-ci ont atteint leurs objectifs " là où ils ont été mis à l'essai. «L'adaptation des institutions d'enseignement du Québec aux carrières industrielles, dit-il, doit se baser sur les réalités actuelles ou prévisibles du Québec et non sur des expériences infructueuses de l'étranger. »" Il est symptomatique, par exemple, que l'un des plus persévérants efforts de l'Université [p. 254] Laval depuis quelques années, maintenant que son enseignement des sciences et de la philosophie est solidement établi, ait porté du côté de la pédagogie et des sciences sociales : celles-ci pour entraîner à une connaissance plus complète de notre société, celle-là pour éclairer les éducateurs et inspirer l'ensemble du système scolaire qui prépare les jeunes à la vie sociale.

Nul ne peut prévoir, dans la conjoncture actuelle, ce que deviendra la répartition des Canadiens français dans les carrières commerciales et industrielles ou le degré de leur participation active à la direction et à la possession des grandes entreprises. Au sujet du premier point, M. Hughes analyse les raisons susceptibles de retenir encore un certain temps nos techniciens dans les carrières commerciales, les carrières bureaucratiques ou les activités économiques qui ne les obligent pas à quitter notre milieu culturel. Quant à l'ascension vers la propriété des grandes industries, quelques exemples récents prouvent de nouveau qu'elle peut être réalisée. Ces exemples prouvent aussi que les Canadiens français ont les qualités nécessaires pour réussir dans les « grandes affaires ». Mais là n'est pas le problème.

Les Canadiens français qui ont atteint ces sommets ne l'ont pu qu'en produisant (qu'il s'agisse de briques, de textile, de bière, de navires ou de munitions) pour un marché national, continental ou international et qu'en utilisant les mêmes institutions et les mêmes procédés qui ont cours dans le monde technologique et financier nord-américain. Au surplus, il semble peu probable que ces cas de réussite se multiplient ou se généralisent. Notre époque, après avoir assisté à la dépersonnalisation de la propriété industrielle assiste maintenant à la dénationalisation de celle-ci. M. Hughes nous rappelle avec un grand réalisme que «c'est le sort du Québec de connaître sa gigantesque expansion industrielle à un moment où le capitalisme (est devenu) un encerclement colossal, inéluctable, d'institutions impersonnelles ». Notre époque n'est plus celle «où d'immenses fortunes pouvaient s'édifier dans l'industrie». Le nouvel industrialisme ne produit plus des «hommes entreprenants qui consacrent avec succès toute leur vie et leurs talents au service des grandes institutions industrielles $\gg$. La carrière de ces grands fonctionnaires de l'industrie, comme M. Hughes l'indique enfin, exige qu'en plus d'être appelés à circuler de pays en pays, ils s'identifient, dans leur vie professionnelle et sociale, avec la «fraternité [p. 255] des hommes prospères ». Pour le Canadien français, une telle carrière, même si elle se passe au Canada, signifiera l'association intime avec des anglophones et l'adoption de l'anglais comme langue pratique. 
Qu'on le déplore ou non, la reconquête économique par les Canadiens français dont on a tant parlé depuis vingt ans ne peut s'accomplir à notre époque sous l'inspiration d'une philosophie artisanale ni par les soins d'un patronat de type personnel qui caractérisaient une époque révolue. Le dilemme souligné par M. Maurice Tremblay est inéluctable : il est impossible de vouloir à la fois perpétuer certains postulats du nationalisme canadien-français et entrer en concurrence réelle avec les entreprises capitalistes canadiennes et nord-américaines. " Il était et il est encore utopique, écrit-il avec beaucoup de justesse, de prétendre appliquer telle quelle une philosophie traditionnellement ethnocentrique à un ordre économique qui s'exerce dorénavant à l'échelle continentale ». Vouloir concilier ces deux données incompatibles signifie se placer dans une situation contradictoire. La persistance d'une telle contradiction entraîne le désarroi idéologique et psychologique dont parle encore M. Tremblay.

Comment nous dégager de ce désarroi et nous acheminer sur des voies prometteuses tout en demeurant fidèles à notre culture ? M. Minville a raison de rappeler que « ce qui dans notre passé social doit être retenu, c'est l'esprit dont procédaient les institutions, les modes de vie ». C'est cet esprit, alerté au contact de situations nouvelles, qui doit permettre à la culture canadiennefrançaise d'intégrer les éléments de la technologie industrielle moderne nécessaires à la prospérité économique. Mais ce serait succomber à l'erreur contre laquelle nous met en garde Herbert Frankel, d'opposer comme deux entités antinomiques la civilisation industrielle et la culture canadiennefrançaise. Toutes les cultures modernes se sont incorporé, à des degrés divers, la technologie, le régime de travail et les institutions financières et sociales dont l'ensemble caractérise l'industrialisme moderne. Celui-ci n'est, de soi, ni matérialiste ni quantitatif. C'est aux individus et aux civilisations qui l'utilisent qu'il incombe de lui accorder son importance relative dans leur philosophie de la vie et dans l'échelle des valeurs qu'ils établissent entre les préoccupations spirituelles, intellectuelles et matérielles de l'homme. L'usine d'Arvida ne semble pas plus nocive en soi [p. 256] qu'un atelier de menuiserie, et il n'apparaît pas plus malaisé pour le président d'une avionnerie ou le tisserand anonyme de Magog de garder le sens de la responsabilité ou de devenir des lettrés ou des saints que pour le cultivateur de Saint-Augustin ou le modeste patron d'une fabrique de chaussures. Les valeurs de civilisation, en définitive, résident dans le cour de l'homme individuel et c'est lui qui doit décider de l'usage qu'il doit en faire.

Ces problèmes économiques et culturels ne sont pas particuliers au Canada français. Pour autant, il importe de les considérer dans la perspective d'une comparaison avec d'autres pays anciens et contemporains dont l'aventure fut semblable à la nôtre, et non plus de façon exclusivement introspective. Un tel effort d'objectivation entraînera une plus grande auto-détermination et une libération.

C'est grâce à une telle franchise que, dans le cadre de la Confédération canadienne, nos relations avec nos compatriotes anglophones ont acquis l'allure sereine que nous leur connaissons. Ces relations sont maintenant bien engagées. On abandonne petit à petit l'aigreur ou le lyrisme qui nous 
empêchait jadis d'être francs les uns avec les autres. Il y aura toute une histoire à écrire des étapes qui ont rendu possible ce duo presque harmonieux ${ }^{1}$. La phase difficile de notre mariage de raison avec le Canada est en voie de prendre fin. Notre pays reconnaît maintenant de plus d'une manière qu'il est composé de deux grands groupes ethniques et qu'il est essentiellement inspiré par deux civilisations. Le Rapport Massey-Lévesque (lequel a quand même été interprété dans notre province comme un acte hostile et néfaste) a officiellement reconnu ce fait capital. Nous n'avons plus à justifier notre présence. Les premiers occupants du pays (après les Indiens) ont droit de cité. Comme le rappelait très récemment le vice-recteur de l'Université Laval, $\mathrm{M}^{\mathrm{gr}}$ A.-M. Parent, « par son importance numérique aussi bien que par la valeur des traditions dont il est le dépositaire et le dispensateur, le groupe français est devenu un élément essentiel de la physionomie propre de notre pays dont il contribue à accroître la richesse spirituelle ${ }^{2}{ }^{2}$.

[p. 257] Nous avons même été trop peu conscients du fait que notre crise de croissance politique en tant que groupe ethnique a de beaucoup devancé, mutatis mutandis, celle du Canada en tant que nation. Il est regrettable que nous ayons si longtemps persisté à parler des «Anglais » alors qu'il en restait si peu en ce pays. Nous avons porté trop peu d'attention à l'avènement d'un sobre nationalisme canadien qui nous doit beaucoup ${ }^{3}$. Notre propre prudence politique, peut-être mêlée d'astuce normande, est de beaucoup antérieure à la pondération que manifeste le Canada dans ses relations internationales.

Ceci ne signifie pas que la situation des Canadiens français, si elle est maintenant reconnue sur le plan national et politique, n'en demeure pas moins difficile. Loin de là. Nous sommes une enclave culturelle. Liés à Rome par la religion et à la France par la civilisation, nous sommes l'un des deux éléments politiquement essentiels d'un pays qui est lui-même, par vocation géographique, partie d'un triangle nord-atlantique. Si nous sommes nordaméricains par naissance, nous sommes français par la civilisation et la langue, catholiques par tradition ou par conviction. Plusieurs questions qui se présentent comme des dilemmes exigeront des solutions prochaines. Comment concilier le souci d'une certaine prospérité temporelle collective avec les exigences spirituelles de la culture et du christianisme dont nous nous réclamons ? Comment atteindre un contrôle efficace de l'économie de notre partie de continent en face des impératifs du capitalisme moderne ? Chaque individu peut trouver facilement ses propres réponses. Mais que fera la collectivité ?

Jean-C. FALARDEAU

En fait, cette histoire a commencé d'être écrite. Le Conseil canadien de Recherche en Sciences sociales a amorcé, depuis quelques années, une vaste série d'études actuellement en cours sur les principaux aspects des relations Anglais-Français au Canada.

2 Discours présidentiel au cinquième congrès de l'Association canadienne des Éducateurs de Langue française, à Saint-Boniface, Manitoba, le 7 août 1953.

3 Voir en particulier, Jean BRUCHÉSI, Canada, réalités d'hier et d'aujourd'hui, Montréal, Les Éditions Variétés, 1948, ch. X; H. Mason WADE, The French-Canadian Outlook, New York, The Viking Press, 1946, ch. VI ; Gustave LANCTÔT, op. cit., p. 279. 